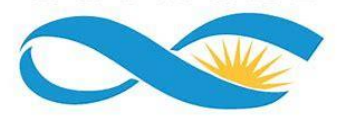

UNIVERSIDAD NACIONAL DE LA PLATA

FACULTAD DE CIENCIAS VETERINARIAS

Trabajo de Tesis realizado como requisito para optar al título de DOCTOR EN CIENCIAS VETERINARIAS

\title{
ESTUDIO DE LA APOPTOSIS EN CULTIVOS CELULARES INFECTADOS CON EL VIRUS DE LA ARTERITIS EQUINA
}

\author{
Autor: MV. ABEYÁ, MARÍA MERCEDES
}

Director: Dra. Echeverría, María Gabriela

Codirector: Dr. Metz, Germán Ernesto

Lugar de trabajo: Cátedra de Virología, Facultad de Ciencias Veterinarias, Universidad Nacional de La Plata

Miembros del Jurado:

Dr. Barbeito, Claudio G. Dr. Gómez, Ricardo M. Dr. Mórtola, Eduardo C. 


\section{PUBLICACIONES PARCIALES DEL TRABAJO DE TESIS}

\section{PUBLICACIONES (revista)}

- Estudio de la apoptosis en cultivos celulares infectados con el virus de la Arteritis Equina. M.M. Abeyá, M.G.Echeverría, G.E.Metz. Analecta Veterinaria, 2014; 34:44.

- Intrinsic, extrinsic and endoplasmic reticulum stress-induced apoptosis in RK13 cells infected with equine arteritis virus. G. E. Metz, I. Galindo, M. M. Abeyá, M. G. Echeverría, C. Alonso. Virus Research, 2016; 213:219-223.doi: 10.1016/j.virusres.2015.12.010.

- Equine arteritis virus cytopathic effect: caspase-dependent cell death as the major consequence observed. M. M. Abeyá, R. Franco Cruz, I. Correas, F. A. Osorio, M. G. Echeverría and G. E. Metz. Journal of Microbiology and Experimentation; Volume 2. Number 4. doi: 10.15406/jmen.2018.06.00210, ISSN:2373-437X.

- Evaluation of apoptosis markers in different cell lines infected with Equine Arteritis Virus. G. E. Metz, M. M. Abeyá, M. S. Serena, C. J. Panei and M. G. Echeverría. Biotechnic and Histochemistry. doi: 10.1080/10520295.2018.1521989

\section{PRESENTACIONES EN REUNIONES CIENTIFICAS (modalidad posters)}

- Activación de Caspasas por el virus de la Arteritis Equina en células RK13. G.E. Metz, I. Galindo, M.M. Abeyá, M.G. Echeverría, C. Alonso. XI Congreso Argentino de Virología. 23 al 26 de junio de 2015. Buenos Aires, Argentina. 
- Proteínas recombinantes del virus de la Arteritis Equina y su relación con la apoptosis celular. M.M. Abeyá, M.G. Echeverría, M.R. Gonzales Baro, G.E. Metz, C.J. Panei, M.S. Serena. XXIII Jornadas de Jóvenes Investigadores, Grupo Montevideo, UNLP. 25 al 27 de agosto de 2015. La Plata, Buenos Aires, Argentina.

- Expression of gP5 and M protein from Equine Arteritis Virus in mammalian cells and its relation with apoptosis. GE. Metz, M.M. Abeyá, M.S. Serena, C.J. Panei, M.L. Susevich, M.G. Echeverría. 97th Annual Conference of Researcher Workers on Animal Diseases (CRWAD). 4 al 6 de diciembre de 2016. Chicago, Illinois, Estados Unidos.

- Estudio de la vía extrínseca de apoptosis en distintos cultivos celulares infectados con el virus de arteritis equina. G.E.Metz, M.M. Abeyá, M.S. Serena, C.J. Panei, M.G. Echeverría. XII Congreso Argentino de Virología. 26 al 28 de septiembre de 2017. Buenos Aires, Argentina.

- Activación del stress del retículo en células Vero E6 y su importancia en la apoptosis celular inducida por el virus de la arteritis equina. M.M. Abeyá, G.E. Metz, I. Correas, C. Prieto Suaréz, M.R. Gonzalez Baró, F.A. Osorio, R. Franco Cruz, M.G. Echeverría. XII Congreso Argentino de Virología.26 al 28 de septiembre de 2017. Buenos Aires, Argentina.

- Equine arteritis virus Bucyrus strain infection activates the reticulum stress response in Vero E6 cells, leading to apoptosis. M.M. Abeyá, G.E. Metz, I. Correas, C. Prieto Suaréz, M.R. Gonzalez Baró, F.A. Osorio, R. Franco Cruz, M.G. Echeverría. 
Nebraska University Annual Symposium. 20 de Octubre de 2017.Lincoln, Nebraska, Estados Unidos.

\section{PRESENTACIONES EN REUNIONES CIENTIFICAS (modalidad exposición oral)}

- Estudio de la apoptosis en cultivos celulares infectados con el virus de la Arteritis Equina. M.M. Abeyá, M.G. Echeverría, G.E. Metz. Jornadas de Ciencia y Técnica 2014, FCV-UNLP. 28 de noviembre de 2014. La Plata, Buenos Aires, Argentina.

- Markers of Apoptosis in different cell lines by Equine Arteritis Virus. M.M. Abeyá, G.E. Metz, M.S. Serena, C.J. Panei, C.G. Aspitia, M.G. Echeverria. 97th Annual Conference of Researcher Workers on Animal Diseases (CRWAD). 4 al 6 de diciembre de 2016. Chicago, Illinois, Estados Unidos.

\section{Esta tesis fue financiada por:}

-Consejo Nacional de Investigaciones Científicas y Técnicas (CONICET). Cátedra de Virología, FCV-UNLP. 2014-2018. La Plata, Buenos Aires, Argentina.

-Beca Programa BEC.AR (Programa de becas de Formación en el exterior en Ciencia y Tecnología). Nebraska Center for Virology and School of Veterinary and Biomedical Sciences. 2016-2017. Lincoln, Nebraska. 


\section{AGRADECIMIENTOS}

- A la Dra. Gabriela Echeverría, gracias Gaby por abrirme las puertas del laboratorio, por confiar en mí y permitirme trabajar libremente, enseñándome, motivándome y ayudándome siempre a ver "el vaso medio lleno".

- Al Dr. Germán Metz, por compartir conmigo su experiencia, conocimiento y brindarme toda la ayuda en los experimentos, siempre con la mejor voluntad.

- $\quad$ A la Dra. Cecilia Galosi y al Dr. Marcelo Pecoraro, por ser grandes personas.

- Al Dr. Hernán Sguazza, por contagiarme su amor a la ciencia y guiarme. Gracias Her por todos los momentos compartidos.

- A las Dras. Maria Rita Gonzalez Baro y Elizabeth Cattaneo, por la confianza y sus conocimientos y tiempo en el microscopio de fluorescencia del INIBIOLP.

- A mis compañeros de Viro y alrededores, los mejores que podría haber encontrado. Gracias Colo, Marie, Caro, Lau, Mumi, Nadia, Vivi, Lau, Pancho, Lean, Marco, Fito, Sole, Javi, Ale, Romi, Marie, Majo, Hernancito, Dai, Walter, Flor y Adri.

- A Dr. Fernando Osorio y mis compañeros del Nebraska Center of Virology, por hacerme sentir como en casa a tantos kilómetros y por lo mucho que me enseñaron.

- A los Dres. Udeni Balasuriya y Peter Timoney del Gluck Equine Research Center de Lexington, Kentucky por recibirme tan amablemente.

- A los Dres. Claudio Barbeito, Alicia Flamini, Cristina Gobello y Yanina Corrada por ser mis primeros maestros en la docencia e investigación. 
- Al grupo editorial de Analecta Veterinaria, gracias por elegirme y darme la oportunidad de participar. En especial a Mónica Diessler por las charlas entre mates, la dedicación y lo mucho que me instruyo.

- A mis jurados, por tomarse tiempo en sus agitadas agendas para leer los informes de avance y aconsejarme siempre. Es un honor para mí ser evaluada por un jurado del más alto nivel académico y humano.

- Al Laboratorio de Análisis Clínicos del Hospital Escuela y a la cátedra de Parasitología Comparada por el apoyo en los últimos meses de trabajo.

- A mis padres, por su amor incondicional, por confiar en mí y darme la posibilidad de estudiar. Son mi ejemplo a seguir (Te extraño mucho papá).

- A mis abuelos, donde sea que estén, sepan que me dieron la mejor infancia del mundo.

- A mis hermanos, mis tres pilares en todo momento. Los quiero muchísimo.

- A mis sobris, la debilidad absoluta de la"tía Mer".

- A los amigos de toda la vida, en especial a Vane, Maca, Sabri, Oli, Ros, Romi, Pao y Pablitin.

- A todos los perros que tuve (Nahuel, Lira, Camila 1, Camila 2, Butz, Ramón, Rusa, Doguito, Negrita, Arturo, Osita, Moro y Sire) y a todos los que no pude adoptar. 
$\underline{\text { ÍNDICE GENERAL }}$

\begin{tabular}{ll|l} 
PORTADA & I
\end{tabular}

PUBLICACIONES PARCIALES DEL TRABAJO DE TESIS II

AGRADECIMIENTOS V V

$\begin{array}{lll}\text { INDICE GENERAL } & \text { VII }\end{array}$

INDICE FIGURAS Y TABLAS IX IX

$\begin{array}{lll}\text { RESUMEN XIII } & \text { X }\end{array}$

SUMMARY X XV

ABREVIATURAS Y SÍMBOLOS XVII

\begin{tabular}{l|l} 
INTRODUCCIÓN & 2
\end{tabular}

1. VIRUS DE LA ARTERITIS EQUINA 6

2. INTERACCIÓN VIRUS-CÉLULA 17

$\begin{array}{ll}\text { 3. ARTERITIS VIRAL EQUINA } & 23\end{array}$

4. APOPTOSIS $\quad \mathbf{5 0}$

$\begin{array}{ll}\text { HIPÓTESIS Y OBJETIVOS } & 67\end{array}$

MATERIALES Y MÉTODOS $\quad 69$

$\begin{array}{ll}\text { RESULTADOS } & 96\end{array}$

CAPÍTULO 1: "Apoptosis observada en cultivos infectados con los viriones del

VAE completos y controles" 97

CAPÍTULO 2: “Apoptosis observada en cultivos transfectados con construcciones

recombinantes del VAE" 112 
CAPÍTULO 3: “Experiencias complementarias -detección de caspasa-12 y uso de Inhibidores específicos"

141

DISCUSIÓN

153

ANEXO SECUENCIAS

172

CONCLUSIONES

176

BIBLIOGRAFÍA

178 


\section{INDICE DE FIGURAS Y TABLAS}

\section{FIGURAS:}

Figura 1: Representación esquemática de la morfología del VAE

Figura 2: Representación esquemática del genoma del VAE

Figura 3: Esquema de las vias apoptóticas

Figura 4: Esquema del vector pGEMT-easy

Figura 5: Esquema del vector pcDNA3.1(+)

Figura 6: Tinción NA/BE de cultivos celulares infectados con distintas cepas del VAE, a diferentes tiempos pi y controles

Figura 7: Citometría de flujo de cultivos celulares infectados con distintas cepas del VAE, a diferentes tiempos pi y controles 105

Figura 8: Diagramas con los valores de citometría de cultivos celulares infectados con distintas cepas del VAE, a diferentes tiempos pi y controles 108

Figura 9: PCR con cebadores diagnósticos del VAE 115

Figura 10: PCR con cebadores específicos para el gen gP5 del VAE 116

Figura 11: PCR con cebadores específicos para el gen M del VAE

Figura 12: PCR con cebadores específicos para el gen $\mathrm{N}$ del VAE

Figura 13: PCR purificadas de los genes gP5, $\mathrm{M}$ y $\mathrm{N}$ de las cepas del VAE

Figura 14: PCR con cebadores M13 del vector pGEM-inserto especifico de los genes gP5, 
Figura 15: Minipreps del vector pGEM-ligando específico de los genes gP5, M y $\mathrm{N}$ de las cepas del VAE

Figura 16: Digestiones del vector pGEM-ligando especifico de los genes gP5, $\mathrm{M}$ y $\mathrm{N}$ de las cepas del VAE

Figura 17: PCR con cebadores pCDNA del vector pCDNA-inserto especifico de los genes gP5, M y $\mathrm{N}$ de las cepas del VAE

Figura 18: Minipreps del vector pCDNA-ligando especifico de los genes gP5, $\mathrm{M}$ y $\mathrm{N}$ de las cepas del VAE

Figura 19: PCR con cebadores pCDNA del vector pCDNA-inserto especifico de los genes gP5, M y $\mathrm{N}$ de las cepas del VAE

Figura 20: Identificación de las concentraciones de geneticina citotóxicas para células RK-

Figura 21: Análisis de la expresión de las construcciones recombinantes en geles de poliacrilamida 125

Figura 22: Análisis de la expresión de la expresión por Western blot de las construcciones recombinantes

Figura 23: Análisis de la expresión por retrotranscripción del ARN mensajero y PCR con cebadores específicos de los genes gP5, M y N de las cepas del VAE 128

Figura 24: Detección de apoptosis por fragmentación del ADN de los cultivos RK-13 transfectados con los genes gP5, M y N de las cepas del VAE 
Figura 25: Detección de apoptosis por tinción diferencial (NA/BE) de los cultivos transfectados con las construcciones pCDNA de los genes gP5, M y $\mathrm{N}$ de las cepas del VAE

130

Figura 26: Detección de apoptosis por citometría de flujo de los cultivos transfectados con las construcciones pCDNA de los genes gP5, M y N de las cepas del VAE

Figura 27: Detección de apoptosis por activación de caspasas detectada por inmunotinción de los cultivos transfectados con las construcciones pCDNA de los genes gP5, $\mathrm{M}$ y $\mathrm{N}$ de las cepas del VAE

Figura 28: Detección de la activación de la caspasa-12 por Western Blot

Figura 29: Determinación de la actividad del inhibidor de caspasa-12 (Z-ATA-FMK) por citometría de flujo

Figura 30: Determinación de la actividad de los distintos inhibidores de muerte por citometría de flujo

151

\section{TABLAS:}

Tabla 1: Cuadro comparativo de Apoptosis y Necrosis celular 52

Tabla 2: Reactivos utilizados en las reacciones de PCR

Tabla 3: Protocolos utilizados en las reacciones de PCR

Tabla 4: Reactivos utilizados para la preparación de los geles de corrida 87

Tabla 5: Reactivos utilizados para la preparación del gel de apilamiento 88

Tabla 6: Anticuerpos y sus diluciones empleados en la inmunodetección 
Tabla 7: Valores basales de citometría de cultivos celulares transfectados con las construcciones pCDNA de los genes gP5, M y N de las cepas del VAE y luego de la infección viral y la inducción con STS

Tabla 8: Valores porcentuales de muerte celular obtenidos por citometría de flujo en la Figura 29

Tabla 9: Valores porcentuales de muerte celular obtenidos por citometría de flujo en la 


\section{Resumen}

La arteritis viral equina es una enfermedad viral muy importante económicamente en la industria equina cuya prevalencia continúa en aumento, posiblemente debido a la intensificación del transporte de caballos y semen congelado. Es una de las principales causas de aborto, neumoenteritis fulminante en recién nacidos y enfermedad respiratoria alrededor del mundo, donde el macho infectado puede convertirse en portador y transmisor del virus durante el servicio. El virus pertenece a la familia Arteriviridae, es envuelto, posee ARN de simple cadena y contiene numerosas proteínas. Las principales proteínas virales, en cuanto a su abundancia y antigenicidad, son la $\mathrm{N}$ (de la nucleocápside) y las proteínas gP5 y M (de membrana). El proceso de apoptosis se encuentra estrictamente controlado a nivel genético y diversos factores pueden alterar el proceso de manera de inducir o inhibir esta respuesta celular. Si bien hay estudios que muestran que este virus induce apoptosis en cultivos celulares identificando distintas enzimas participantes, no se conoce cuál o cuáles proteínas virales estarían involucradas en este proceso. El objetivo general de este trabajo es estudiar la inducción de la apoptosis en cultivos celulares tras la infección con el virus. Se estudiaron diferentes mecanismos moleculares implicados en este proceso mediante el empleo de distintas cepas virales de variada patogenicidad a través de la expresión diferencial de proteínas virales en cultivos. Como primer paso se utilizó el virión completo de las tres cepas virales seleccionadas (Bucyrus, LP-01 y GLD-LP-ARG) y se infectaron 3 líneas celulares (RK-13, Vero y BHK-21), incluyendo controles positivos y negativos. Luego se realizaron construcciones en pCDNA3.1(+) para cada uno de los genes correspondientes a las 
proteínas M, N y gP5 del VAE y se transfectaron cultivos celulares. Además se evaluó la vía del retículo, representada por la caspasa -12, utilizando distintos inhibidores en células RK-13. Se utilizaron tanto métodos cualitativos como cuantitativos. Nuestros resultados indican que la magnitud de apoptosis observada en los cultivos celulares infectados está directamente relacionada con la patogenicidad y la MOI de la cepa viral del VAE y el tiempo posinoculación. Se observó además que todas las construcciones recombinantes inducen un grado variable de apoptosis, siempre menor a la observada con el virión completo pero mayor respecto a los cultivos que expresan el vector vacío. Además, mediante la utilización de staurosporina, reconocido inductor de apoptosis, observamos un efecto antiapoptótico en las construcciones portadoras de la proteína $M$, mientras que, por el contrario, se observó un efecto sinérgico en aquellas que contenían los genes de las proteínas gP5 y N del VAE. Por último evidenciamos que la vía del retículo, representada por la caspasa 12 , es una de las principales rutas apoptóticas activadas por el VAE. La participación en la muerte celular de los distintos genes virales evaluados, abre nuevos interrogantes que estarían destinados a comprender en mayor profundidad la patogenia de enfermedad, con la esperanza de potenciar y perfeccionar las herramientas de prevención, diagnósticas y terapéuticas disponibles actualmente, mediante la puesta a punto de otras herramientas de detección de la actividad viral en la célula huésped.

\section{PALABRAS CLAVES: VIRUS DE LA ARTERITIS EQUINA (VAE), APOPTOSIS, CULTIVO CELULAR, PCDNA3.1(+), CASPASAS, CITOMETRÍA DE FLUJO.}




\section{Summary}

Equine viral arteritis is a highly important viral disease economically in the equine industry whose prevalence continues to increase, possibly due to the intensification of the transport of horses and frozen semen. It is one of the main causes of abortion, fulminating pneumoenteritis in newborns and respiratory disease around the world, where the infected male can become a carrier and transmitter of virus during the service. The virus belongs to the family Arteriviridae, is enveloped, has simple chain RNA and contains numerous proteins. The main viral proteins, in terms of their abundance and antigenicity, are $\mathrm{N}$ (nucleocapsid) and proteins gP5 and M (membrane). The process of apoptosis is strictly controlled at the genetic level and various factors can alter the process in order to induce or inhibit this cellular response. Although there are studies that show that this virus induces apoptosis in cell cultures by identifying different participating enzymes, it is not known which viral proteins or proteins would be involved in this process. The general objective of this work is to study the induction of apoptosis in cell cultures after infection with EAV. Different molecular mechanisms involved in this process were studied through the use of different strains of EAV through the differential expression of viral proteins in cultures. As a first step, the complete virion of the three selected viral strains (Bucyrus, LP01 and GLD-LP-ARG) was used and 3 cell lines were infected (RK-13, Vero and BHK-21), including positive and negative controls. Constructs were then made in pCDNA3.1 (+) for each of the genes corresponding to the $\mathrm{M}, \mathrm{N}$ and gP5 proteins of the VAE and cell cultures were transfected. In addition, the reticulum pathway, represented by caspase -12 , was evaluated using different inhibitors in RK-13 cells. Both qualitative and quantitative 
methods were used. Our results indicate that the magnitude of apoptosis observed in the infected cell cultures is directly related to the pathogenicity and the MOI of the viral strain of the EAV and the posinoculation time. It was also observed that all the recombinant constructs induce a variable degree of apoptosis, always lower than that observed with the complete virion but greater than the cultures that express the empty vector. Furthermore, through the use of staurosporine, a recognized inducer of apoptosis, we observed an antiapoptotic effect in the M protein carrier constructions, whereas, on the contrary, it was observed a synergistic effect in those that contained the genes of the VAE gP5 and N proteins. Finally, we show that the reticulum pathway, represented by caspase 12 , is one of the main apoptotic pathways activated by the VAE. The participation in the cell death of the different viral genes evaluated, opens new questions that would be destined to understand in greater depth the pathogenesis of disease, with the hope of strengthening and perfecting the prevention, diagnostic and therapeutic tools currently available, by putting to the point of other tools for detecting viral activity in the host cell.

KEY WORDS: EQUINE ARTERITIS VIRUS (EAV), APOPTOSIS, CELL CULTURE, PCDNA3.1(+), CASPASES, , FLOW CYTOMETRY. 


\section{ABREVIATURAS Y SÍMBOLOS}

oC: grado centígrado

$\mu l:$ microlitro

$\mu g$ : microgramo

aa: aminoácido

Ac: anticuerpo

ADN/DNA: ácido desoxirribonucleico

AEC: amino etilcarbazol

Ag: antígeno

AIF: (Apoptosis Inducing Factor) Factor inductor de apoptosis

ARN/RNA: ácidoribonucleico

ARNm: ARN mensajero

ARNm sg: ARN mensajero subgenómicos

ARNs: ARN silente

AVE/EVA: Arteritis viral equina

BHK-21: (Baby Hamster Kidney cells) células de riñón de hámster lactante

CAD: (Caspase-3 Activated DNase) ADNasa activada por caspasa-3

$\mathrm{CMH}$ : Complejo Mayor de Histocompatibilidad

$\mathrm{CO}_{2}$ : dióxido de carbono

DAB: diaminobencidina

DMVs: vesículas de doble membrana 
dpi: días postinfección

ECP/CPE: efecto citopatogénico

EDTA: ácido etilendiamintetracético

ELISA: enzimoinmunoanálisis

FC: fijación del complemento

$\mathrm{G}_{\mathrm{L}}$ : glicoproteina mayor (large)

gP: glicoproteína

Gs: glicoproteína menor (small)

h: horas

hpi: horas postinfección

HPV: virus del papiloma humano

HVE: herpes virus equino

IDGA: inmunodifusión en gel de agar

kb: kilo pares de bases

kDa: kilodaltons

LB: linfocito B

M: molar

MEM: medio esencial mínimo

mg: miligramo

MIA: inmunoensayo con microesferas fluorescentes

min: minutos

ml: mililitro 
MOI: multiplicidad de infección

NA/BE: naranja de acridina/bromuro de etidio

nm: nanómetro

nsp: (non-structural protein) proteína no estructural

OIE: Organización Mundial de Sanidad Animal

ORF: marco abierto de lectura

PAGE: electroforesis en geles de poliacrilamida

pb: pares de bases

PBS: solución buffer de fosfato

PCR: reacción en cadena de la polimerasa

$\mathrm{pH}$ : potencial hidrógeno

pi: postinfección

PM: peso molecular

pp: poliproteína

RE: retículo endoplasmático

RK-13: (Rabbit Kidney cells) Células de riñón de conejo

RpRd: ARN-polimerasa dependiente de ARN

RT-PCR: reacción en cadena de la polimerasa con transcripción reversa

SDS: dodecilsulfato de sodio

seg: segundos

SENASA: Servicio Nacional de Sanidad y Calidad Agroalimentaria

SFB: suero fetal bovino 
SN: seroneutralización

STS: staurosporina

Temed: N,N,N,N'-tetrametiletilendiamina

UPR: (Unfolded Protein Response) Respuesta de las proteínas mal plegadas

VAE/EAV: Virus de la Arteritis equina

Vero: (African Green Monkey Kidney cells) Células de riñón de mono verde africano

VFHS: virus de la fiebre hemorrágica de los simios

VLD: virus elevador de la enzima lactato deshidrogenasa del ratón

VSRRP: virus del síndrome reproductivo y respiratorio porcino

VZT: virus de la zariguella tambaleante

WB: Western blot 


\section{ESTUDIO DE LA}

APOPTOSIS EN

CULTIVOS

CELULARES

INFECTADOS CON EL

VIRUS DE LA

ARTERITIS EQUINA 


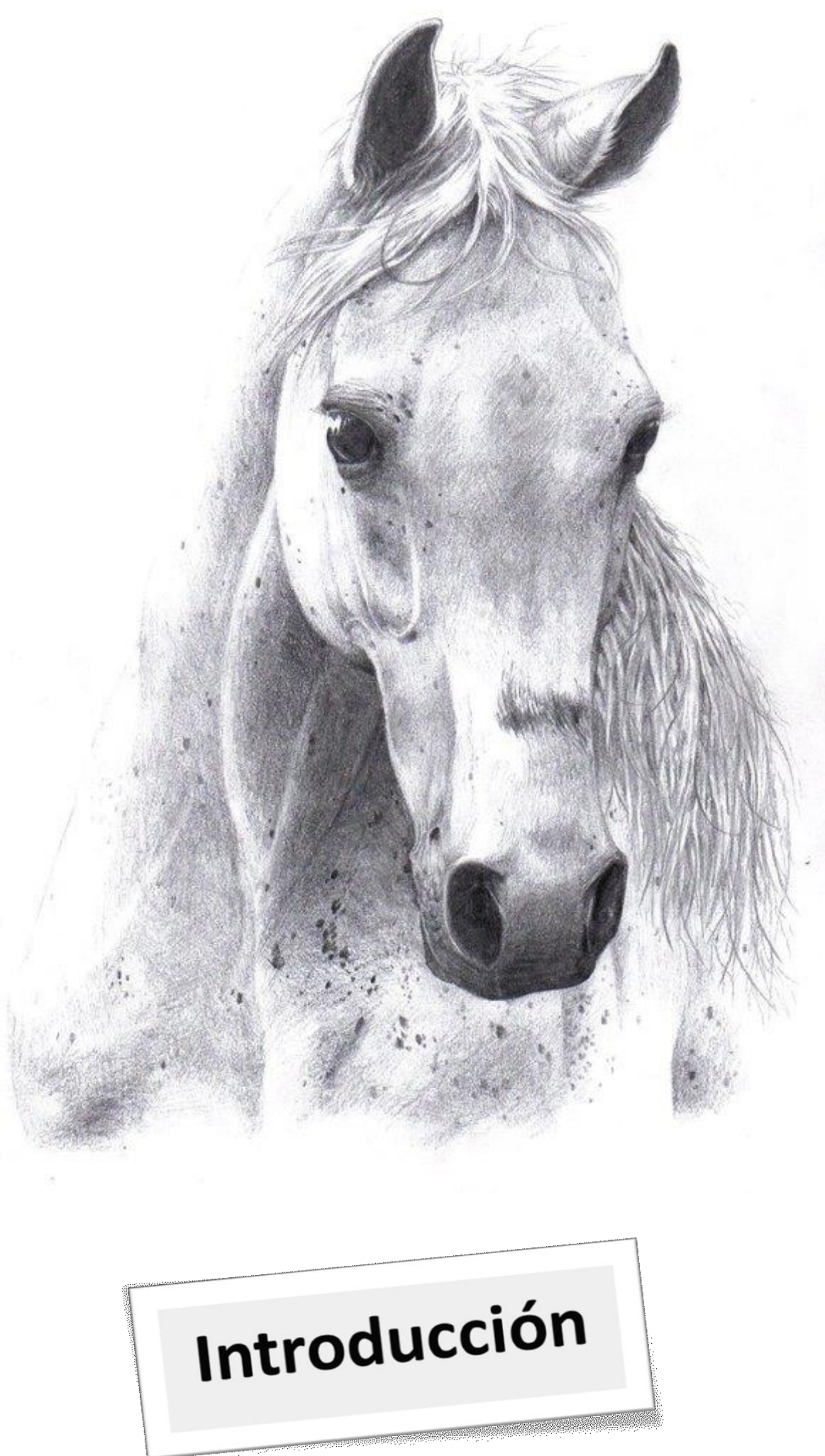




\section{VIRUS DE LA ARTERITIS EQUINA}

1.1 Historia

1.2 Taxonomía

1.3 Morfología

1.3.1 Estructura general del virión

1.3.2 Organización genómica

1.3.3 Proteína de la nucleocápside

1.3.4 Proteínas mayores de envoltura

1.3.5 Proteínas menores de envoltura

\section{VIRUS DE LA ARTERITIS EQUINA-INTERACCIÓN CELULAR}

2.1 Adhesión e ingreso viral

2.2 Replicación del genoma y expresión de genes

2.2.1 Transcripción del genoma y procesamiento de la poliproteína en proteínas no estructurales

2.2.2 Replicación del genoma

2.2.3 Transcripción de ARN subgenómicos y expresión de proteínas estructurales

2.3 Ensamble viral, brotación y liberación

\section{ARTERITIS VIRAL EQUINA}

3.1 Prevalencia de la enfermedad

3.2 Patogénesis de la infección con el VAE 
3.2.1 Vías de infección y diseminación

3.2.2 Patogénesis de la infección generalizada tras la infección por vía respiratoria

3.2.3 Patogénesis del aborto tras la infección por vía respiratoria

3.2.4 Patogénesis de la infección por vía venérea

3.2.5 Mecanismos de persistencia en sementales

\subsection{Signos clínicos}

3.4 Hallazgos patológicos

\subsubsection{Lesiones macroscópicas}

\subsubsection{Lesiones histopatológicas}

3.5 Signos clínicos y patología de la infección con cepas de baja patogenicidad

\subsection{Inmunidad}

\subsection{Diagnóstico}

\subsubsection{Diagnóstico clínico}

3.7.2 Detección del virus, componentes virales y anticuerpos

3.8 Medidas recomendadas ante sospecha de AVE

3.9 Control de la enfermedad

3.10 Situación en Argentina

\section{APOPTOSIS}

\subsection{Generalidades}

4.2 Muerte celular por apoptosis 


\subsubsection{Cambios morfológicos}

\subsubsection{Cambios bioquímicos}

4.2.2.1 Vía extrínseca

4.2.2.2 Vía Intrínseca

4.2.2.3 Vía del retículo endoplasmático

4.2.2.4 Vía ejecutora común

4.3 Modulación viral de la apoptosis

4.4 Arterivirus y apoptosis

4.5 Esquema de vías apoptóticas 


\section{VIRUS DE LA ARTERITIS EQUINA}

\subsection{Historia}

El virus de la arteritis equina (VAE) es el agente etiológico de la enfermedad mundialmente conocida como arteritis viral equina (AVE). EI VAE fue aislado por primera vez en 1953, de un brote de enfermedad respiratoria y aborto en un haras, cerca de Bucyrus (Ohio, EEUU). Sin embargo, las descripciones de brotes de enfermedad, que muy probablemente fueron consecuencia de la infección por el VAE, se han publicado desde finales del siglo XVIII y se denominaron "ojo rosado", "celulitis infecciosa o epizoótica", "influenza erisipelatosa", e " influenza equina" (Pottie y col., 1888; Bergman y col., 1913). En 1957, el agente aislado del brote de Ohio fue nombrado como VAE debido a las lesiones vasculares distintivas que originaba, correspondientes con arteritis (Doll y col., 1968). Un primer e importante brote en Europa ocurrió en Berna (Suiza) en 1964, involucrando 400 caballos (Bürki y Gerber, 1966). Recientemente, el número de brotes de AVE ha aumentado drásticamente en todo el mundo. La AVE es una enfermedad viral económicamente importante y su prevalencia está aumentando, posiblemente debido a la intensificación del transporte de caballos y semen congelado (Balasuriya y col., 2013). Aunque las muertes son muy raras en adultos infectados, la infección viral puede desencadenar una enfermedad aguda, donde las yeguas preñadas pueden abortar y los potrillos tienen riesgo de morir debido a una neumonía o enteritis fulminantes. Además, los sementales pueden convertirse en portadores y transmitir el VAE durante el servicio (Timoney y McCollum, 1993). Si bien la diseminación global y la incidencia del VAE han aumentado durante las últimas décadas, varios aspectos de su patogénesis permanecen 
sin investigar. Una mejor comprensión de la patogénesis del VAE puede conducir a un control eficaz de la enfermedad y a una reducción de las pérdidas económicas.

\subsection{Taxonomía}

El VAE es el virus prototipo del género Equarterivirus, familia Arteriviridae, orden Nidovirales (Kuhn y col., 2016). Los miembros del orden Nidovirales contienen genoma ARN simple hebra sentido positivo el cual se encuentra dentro de una nucleocápside proteica y limitados exteriormente por una bicapa lipídica con proteínas asociadas (Perlman y col., 2012). Los viriones de los nidovirus varían en morfología, desde esféricos a baciliformes, dependiendo de la familia a la cual pertenecen (Lai y Holmes, 2001). Basándose en el análisis filogenético de la ARN-polimerasa dependiente de ARN (RpRd), el orden nidovirales se dividió en tres familias: Arteriviridae, Roniviridae y Coronaviridae (2 subfamilias: Coronavirinae y Torovirinae) (de Groot y col., 2012; Lauber y col., 2012). Los nidovirus causan enfermedades importantes en una amplia gama de huéspedes incluyendo seres humanos, otros mamíferos, pájaros, camarones y peces (de Groot y col., 2012; Granzow y col., 2001; Siddell y Snijder, 2008; Walker y col., 2005), y se caracterizan por una extraordinaria complejidad genética que les permite expandir la gama de hospedadores y adaptarse rápidamente a las condiciones cambiantes ambientales (Ziebuhr y col., 2000).

Los ORFs ubicados en el extremo 3' del genoma de los nidovirus se expresan a partir de un conjunto anidado de ARNm subgenómicos (sg), una propiedad que se reflejó en el nombre del orden viral (nidus en latín significa nido) (Cavanagh, 1997). Tanto el dominio de unión a zinc (contenido en nsp10) como el dominio endorribonucleasa específico (contenido en 
nsp11) no han sido identificados en otras familias de virus ARN, por lo tanto se utilizan para discriminar entre nidovirus y otros virus ARN (Posthuma y col., 2006).

Además del VAE, la familia Arteriviridae contiene otros 4 miembros: el virus del síndrome reproductivo y respiratorio porcino (VSRRP; cerdos), el virus elevador de la enzima lactato deshidrogenasa (VLD; ratones), el virus de la fiebre hemorrágica de los simios (VFHS; primates) (Snijder y Meulenberg, 1998), y el virus de la zarigüeya tambaleante (VZT; zarigüeyas) (Dunowska y col., 2012; Snijder y col., 2013). Los arterivirus tienen una gama altamente restringida de hospedadores y pueden causar infecciones prolongadas o de por vida en su huésped natural (Timoney y McCollum, 1993). La capacidad de persistir en su hospedador sugiere que pueden "escaparse" del reconocimiento y eliminación por parte de la inmunidad del huésped. Sin embargo, los mecanismos de evasión inmune que emplean son, en gran parte, desconocidos.

Existe una considerable variación genética entre las cepas de campo del VAE, como lo demuestran los análisis de secuencias comparativas de los ORFs 2 a 7 (Hornyak y col., 2005). Debido a que el ORF 5, el cual codifica para la proteína glicosilada de membrana gP5, contiene varias regiones variables, se convirtió en el blanco principal para trazar el origen de las cepas del VAE (Balasuriya y col., 1999 y 2004a). Los análisis filogenéticos basados en los genes de la proteína M (ORF 6) y de la proteína N (ORF 7) también confirmaron variaciones entre las cepas del VAE (Chirnside y col., 1994). El análisis de la secuencia del ORF 6 fue utilizado para separar en distintos grupos a los aislamientos del VAE de Europa y de EEUU. Los análisis filogenéticos permitieron identificar dos grupos: el Grupo I comprende a los virus aislados originalmente en Norteamérica; y el Grupo II 
agrupa a los virus aislados originalmente en Europa (Stadejek y col., 1999). Además, se han identificado varios subgrupos dentro de cada grupo. En particular, el Grupo Europeo (II) puede dividirse en dos subgrupos: $I_{1}$ y $\|_{2}$ (Zhang y col., 2010). Recientemente, los virus del linaje norteamericano han sido aislados en Europa y viceversa, indicando la presencia de intercambio viral entre los dos continentes. En Sudamérica, se han identificado aislamientos de ambos grupos del VAE (Echeverría y col., 2003 y 2007; González y col., 2003; Metz y col., 2014). En el continente australiano también se encuentran cepas del VAE pertenecientes al grupo norteamericano. Este intercambio geográfico es probablemente el resultado del movimiento de sementales portadores y del envío del semen contaminado con virus.

La similitud nucleotídica entre los aislamientos norteamericanos y europeos del VAE indica una identidad del $85 \%$ (Balasuriya y col., 1995a y 2004a). Una cepa genéticamente muy diversa del VAE ha sido aislada del semen de un burro en Sudáfrica presentando una homología de sólo el $60 \%$ con respecto a las demás cepas del VAE aisladas hasta el momento, tanto en equinos como en burros (Stadejek y col., 2006). La infección experimental de caballos y burros con la cepa sudafricana ha demostrado que es poco transmisible a los caballos (Paweska y col., 1997).

Genéticamente, el VAE se mantiene bastante estable durante la transmisión, tanto horizontal como vertical, en el curso de un brote de enfermedad. Las variantes genéticas suelen emerger durante infecciones persistentes de sementales (Balasuriya y col., 1999 y 2004a). Los aislamientos del VAE pueden variar marcadamente en su virulencia para 
causar signos clínicos severos, entre ellos el aborto en yeguas preñadas (Balasuriya y MacLachlan, 2004).

\subsection{Morfología}

\subsubsection{Estructura general del virión}

EI VAE es pequeño, esférico, con un diámetro total de 40-60 nm. Su nucleocápside central de 25 a $35 \mathrm{~nm}$ de diámetro esta constituida por una única proteína, la proteína de la cápside (N) que encierra el genoma viral (Horzinek y col., 1971). Los viriones estan envueltos por una membrana lipoproteica, con minúsculas proyecciones superficiales (Horzinek y col., 1971). Se han identificado ocho proteínas estructurales en los viriones del VAE: la proteína de la nucleocápside, fosforilada, de 14 kDa (N) y siete proteínas de envoltura: glicoproteína (gP) 2 (previamente denominada $\mathrm{G}_{\mathrm{s}}$ ), la proteína $\mathrm{E}$ o de envoltura, gP3, gP4, gP5 (anteriormente denominada $G_{L}$ debido a su mayor dimensión en comparación con las otras proteínas estructurales), proteína ORF5a y la proteína M (Figura $1)$. 


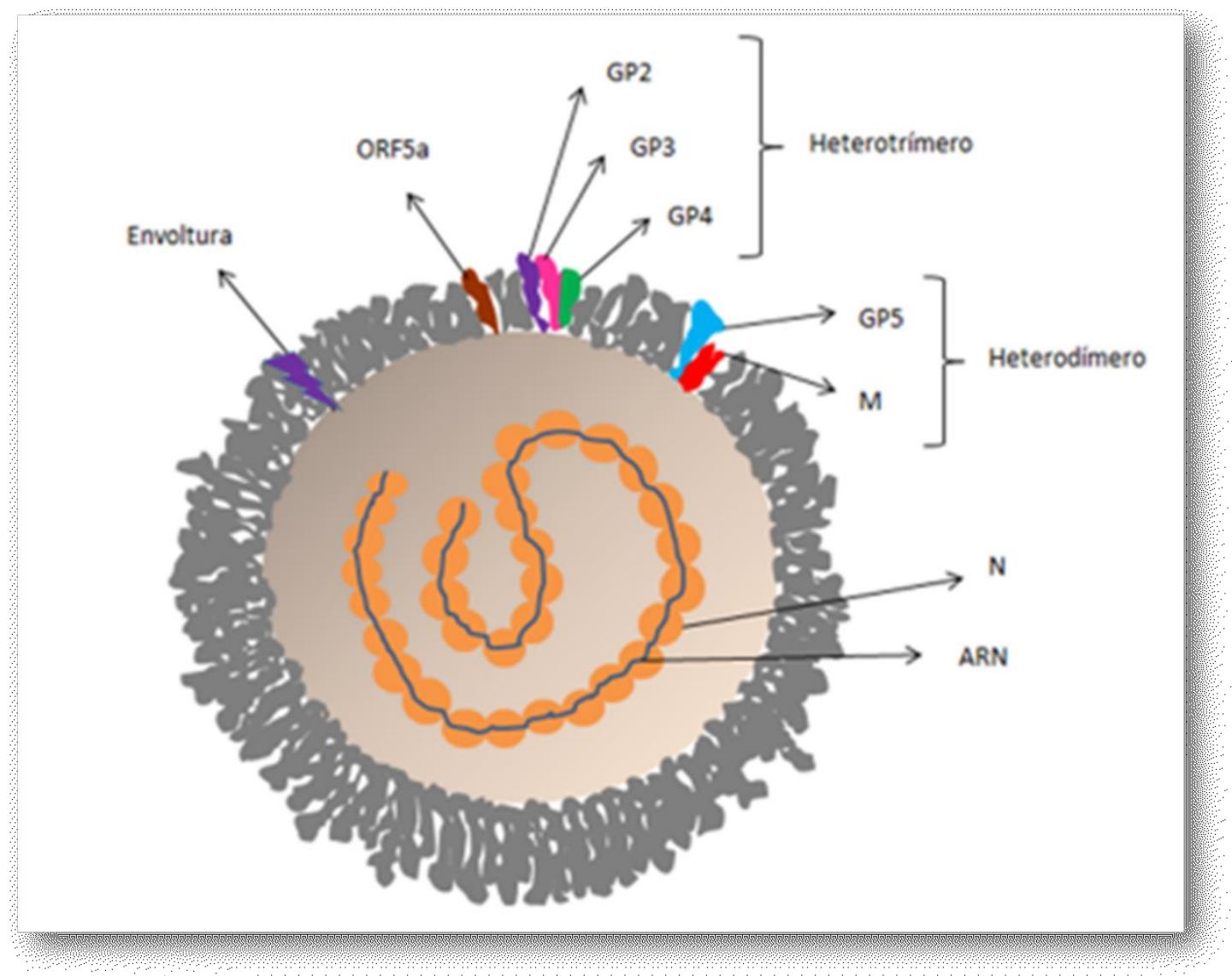

Figura 1: Representación esquemática de la morfología del VAE. Se observa el ARN viral recubierto íntimamente por la proteína $\mathrm{N}$. En la envoltura se representan las proteínas que forman el heterodímero (gP5 y M), el heterotrímero (gP2, gP3 y gP4) al igual que las proteínas no glicosiladas ORF5a y $\mathrm{E}$.

\subsubsection{Organización genómica}

El genoma del VAE consiste en aproximadamente 12,7 kilobases (Kb), es una molécula de ARN simple hebra sentido positivo y se divide en 10 marcos abiertos de la lectura (ORFs): 2 ORFs mayores que codifican para las replicasas y 8 ORFs más pequeños para las proteínas estructurales. Además de las regiones codificantes, el genoma contiene 2 regiones de no codificación, una en su extremo 5' que lleva un cap, y otra en su extremo 3' a la que se adjunta una cola Poli-A (Figura 2). Los dos ORFs mayores que se ubican hacia 5', ORF 1A y ORF 1B, ocupan tres cuartas partes del genoma y se superponen en una pequeña área que 
contiene una señal de cambio de marco de lectura ribosomal (Frame shift) (Figura 2). Las poliproteínas ORF 1A y ORF 1B se procesan en 13 proteínas no estructurales (nsps), incluyendo una ARN-polimerasa dependiente de ARN (RpRd; nsp9). La secuencia del ARN viral río abajo de los ORF 1A y $1 B$ contiene 8 ORFs solapados: $2 a, 2 b, 3,4,5,5 a, 6$ y 7, los cuales codifican para las proteínas estructurales E, gP2, gP3, gP4, gP5, ORF5a, M y N respectivamente (Figura 2) (de Vries y col., 1992).

El ORF 5a se superpone al 5' final de ORF 5 y se encuentra en todas las especies de Arterivirus. La proteína ORF 5a es una proteína de membrana de 59aa y se piensa que es codificada por el mismo ARNm sg que codifica para la glicoproteína gP5. La función de esta proteína todavía no está definida con claridad, pero utilizando estudios de genética reversa se determinó que es la octava proteína estructural de Arterivirus y podría ser importante para la infección viral (Firth y col., 2011).

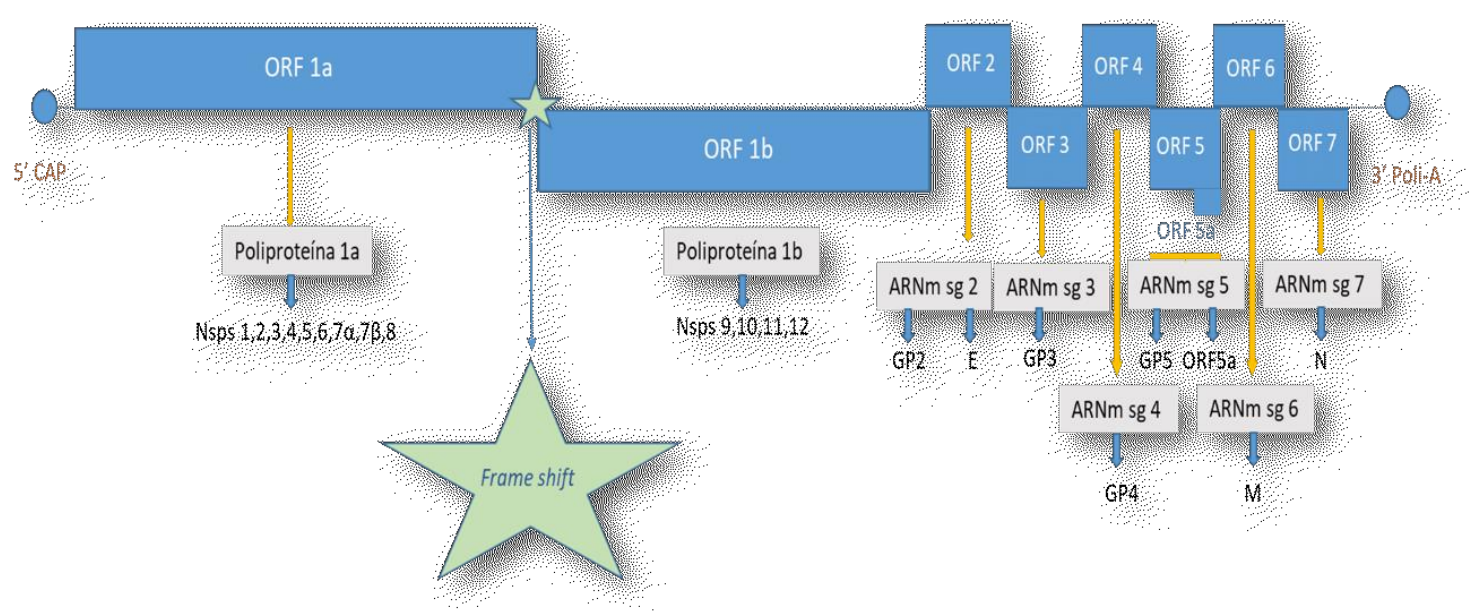

Figura 2: Representación esquemática del genoma del VAE. Hacia el extremo 5 ' se ubican ORF $1 \mathrm{~A}$ y ORF $1 \mathrm{~B}$, los cuales se superponen en una pequeña área que contiene una señal de cambio de marco de lectura ribosomal (Frame shift). Las poliproteínas ORF $1 \mathrm{~A}$ y ORF $1 B$ se procesan en 13 proteínas no estructurales (nsps). La secuencia del ARN viral río abajo de los ORF $1 A$ y $1 B$ contiene 8 ORFs solapados: $2 a, 2 b, 3,4,5,5 a, 6$ y 7 , los cuales codifican para las proteínas estructurales E, gP2, gP3, gP4, gP5, ORF5a, $\mathrm{M}$ y N respectivamente.

\subsubsection{Proteína de la nucleocápside}


La proteína de la nucleocápside (N) es una proteína pequeña, codificada por el ORF 7, con un alto contenido de aminoácidos básicos y de naturaleza hidrofílica (de Vries y col., 1992). La proteína N es fosforilada y está presente en el virión como monómero (Snijder y Meulenberg, 1998). Esta proteína se expresa abundantemente en las células infectadas y constituye alrededor de 35 a 40\% del total de proteínas en el virión (de Vries y col., 1992). El núcleo celular contiene normalmente trazas de la proteína $\mathrm{N}$ del VAE, la cual se dirige allí inmediatamente después de su traducción. La proteína $\mathrm{N}$ se localiza como focos, muy probablemente en nucléolos, en vista de los hallazgos obtenidos con el VSRRP (Rowland y col., 1999). Aunque sólo pequeñas cantidades de la proteína $\mathrm{N}$ están normalmente presentes en el núcleo, todas las moléculas de la misma se transportan inicialmente a esta organela.

La replicación genómica y la síntesis del ARNm pueden continuar normalmente estando la proteína $\mathrm{N}$ atrapada en el núcleo. Por lo tanto se deduce que la proteína $\mathrm{N}$ del VAE es prescindible para la síntesis de ARN viral en el citoplasma (Molenkamp y col., 2000). Sin embargo, puesto que desempeña un papel importante en encapsidamiento del ARN genómico viral, y en el montaje del virus al interactuar con las proteínas de la envoltura, la proteína $\mathrm{N}$ es vital para la producción de partículas infecciosas virales (Wieringa y col., 2004). Debido a que, tanto la formación de la nucleocápside como el budding de arterivirus son acontecimientos citoplásmicos (Snijder y Meulenberg, 1998) la proteína de $\mathrm{N}$ precisa ser transportada nuevamente al citoplasma para cumplir su papel en la biogénesis del virión. El detalle de como ocurre el transporte núcleo-citoplásmico de la proteína de $\mathrm{N}$ aún no se conoce. En primer lugar, el transporte nuclear con frecuencia 
implica la fosforilación de la proteína y, por tanto, esta vía podría utilizarse para lograr una modificación post-traduccional esencial. En segundo lugar, puesto que el núcleo está implicado en una gran variedad de procesos celulares (Olson y col., 2000), la localización nuclear/nucleolar de la proteína de $\mathrm{N}$ puede ser parte de una estrategia viral para modular funciones de la célula huésped. Estudios con coronavirus también han revelado la importación nuclear y nucleolar de la proteína $\mathrm{N}$, un proceso que ocurriría para interrumpir la división de la célula huésped (Wurm y col., 2001). Estas observaciones sugieren que la importación nuclear de la proteína $\mathrm{N}$ es un mecanismo común importante tanto para el VAE como para otros nidovirus.

\subsubsection{Proteínas mayores de envoltura}

La proteína de membrana no glicosilada (M) y la glicoproteína mayor de envoltura gP5 son las dos proteínas de envoltura principales del VAE y están codificadas por el ORF 6 y 5 , respectivamente (de Vries y col., 1992).

La proteína $\mathrm{M}(16-\mathrm{kDa})$ atraviesa tres veces la envoltura viral con sus segmentos transmembrana, dejando un fragmento corto de 10-18 aa expuesto hacia el exterior del virión (ectodominio) y un residuo de 72 aa orientado hacia el interior (endodominio). En las células infectadas con el VAE, también se observan proteínas M homodímericas unidas por puentes disulfuro, pero estas no se incorporan a los viriones (Snijder y Meulenberg, 1998).

La proteína gP5 (30 a 45-kDa; 255aa) es una proteína glicosilada con un ectodominio de tamaño variable (19-116aa), tres dominios transmembrana y un endodominio de 64 aminoácidos (Balasuriya y MacLachlan, 2004). La proteína gP5 expresa los determinantes 
de neutralización virales, todos ubicados en el ectodominio (Balasuriya y col., 1997 y 2004b).

Las proteínas M y gP5 están presentes en viriones en cantidades equimolares. Cuando se expresan individualmente, las proteínas gP5 y $\mathrm{M}$ se localizan sólo en el retículo endoplasmático (RE). En contraste, cuando son co-expresadas, la proteína M se localiza tanto en el RE como en el aparato de Golgi, mientras la proteína gP5 se encuentra siempre co-localizada con la proteína M en el complejo de Golgi, demostrando que su transporte a esta organela depende de la formación del heterodímero gP5/M. El ectodominio de la proteína gP5 forma un enlace disulfuro con el ectodominio de la proteína M, lo que resulta en la heterodimerización gP5/M (Snijder y col., 2003). Los heterodímeros gP5/M constituyen la matriz proteica básica de la envoltura viral (de Vries y col., 1992 y 1995). Además, las proteínas gP5 y M son indispensables tanto para el ensamblaje del virus como para la producción de partículas virales infecciosas (Wieringa y col., 2004).

\subsubsection{Proteínas menores de envoltura}

Además de las tres principales proteínas estructurales, el virión del VAE contiene cuatro proteínas menores de envoltura: la gP4 (28 kDa), la gP3 (36 a 42 kDa), la gP2b (25 kDa) y la proteína E (8 kDa).

Las proteínas gP4 y gP 2 b están codificadas por el ORF 4 y $2 b$, respectivamente, y son proteínas de membrana integrales tipo I con un dominio terminal de 22-24 aa, el cual es escindido durante el transporte a través del RE (Wieringa y col., 2002).

La proteína gP3 está codificada por el ORF 3 y es una proteína integral de membrana fuertemente glicosilada con secuencias hidrófobas. Los dominios terminales hidrofóbicos 
anclan la proteína gP3 a la membrana. Ninguna parte de su estructura está expuesta citoplásmicamente de forma detectable (Wieringa y col., 2002).

La proteína E es una pequeña proteína integral de membrana (67 aa) no glicosilada codificada por ORF 2a con un dominio hidrofóbico central (40 aa). La proteína E no forma multímeros unidos covalentemente y se asocia con las membranas intracelulares (tanto el RE como el complejo de Golgi) (Snijder y col., 1999).

Las proteínas gP2b, gP3 y gP4 se expresan abundantemente en células infectadas con el VAE, pero solo una pequeña fracción de ellas se ensambla en el virión (Wieringa y col., 2003a). Las proteínas gP2b, gP3 y gP4 forman heterotrímeros (Snijder y col., 2003). Se ha postulado que las proteínas gP2b y gP4 primero forman un heterodímero que luego interactúa con la proteína gP3. El complejo gP2b/gP4/gP3 finalmente se ensambla en el virión (Wieringa y col., 2003a y 2003b). Cuando falta una de las proteínas gP2b, gP3 o gP4 se bloquea la incorporación de las proteínas restantes. Además, dado que la ausencia de la proteína E impide completamente la incorporación de las proteínas gP2b, gP3 y gP4 en el virión, se sugirió la existencia de un complejo gP2b/gP4/gP3/(E) (Wieringa y col., 2004). Se piensa que la proteína $\mathrm{E}$ es el componente que interactúa con el heterotrímero gP2b/gP4/gP3, por un lado, y con el heterodímero gP5/M y/o la nucleocápside, por otro lado. Se ha demostrado que las proteínas E, gP2b, gP3 y gP4 son prescindibles para la formación de partículas similares a virus, mientras que son esenciales para la producción de partículas virales infecciosas, lo que sugiere que el complejo gP2b/gP4/gP3/(E) puede estar involucrado en el proceso de adhesión y entrada celular (Molenkamp y col., 2000). 


\section{INTERACCIÓN VIRUS- CÉLULA}

EI VAE puede ser propagado en una variedad de cultivos celulares primarios como macrófagos equinos (Moore y col., 2003a), células endoteliales equinas (Moore y col., 2003b), células de riñón equino (McCollum y col., 1961) y células de riñón de hámster (Wilson y col., 1962). EI VAE también puede replicar eficientemente en numerosas líneas celulares comerciales tales como riñón de conejo (RK-13) (McCollum y col., 1962), riñón de hámster lactante (BHK-21) (Hyllseth, 1969) y riñón de mono verde africano (Vero) (Konishi y col., 1975). La infección por el VAE de células primarias y líneas celulares continuas es altamente citocida. El efecto citopático (ECP) se caracteriza por redondeamiento y desprendimiento del soporte celular (McCollum y col., 1962). En las células primarias equinas, un ciclo replicativo toma de 4 a 6 hs y el titulo viral máximo se obtiene a las 36 hs post-infección (hpi) (Moore y col., 2002).

La replicación de virus ARN positivo $(A R N+)$ en células eucariotas depende de un único proceso de síntesis de ARN dependiente de ARN. Una característica común es la participación de las membranas de las células hospedadores que a menudo se modifican para alojar el complejo de replicación del virus ARN+ (Pedersen y col., 1999). Al igual que con otros virus, la infección celular del VAE implica adhesión, entrada, replicación del genoma viral, transcripción de ARNm, síntesis de proteínas virales, ensamblaje, gemación y liberación.

\subsection{Adhesión viral y entrada}

Los primeros pasos para la replicación son la adhesión viral a un receptor específico en una célula susceptible y la posterior internalización. Análogamente a los que ocurre con 
otros virus ARN y, debido a que es reconocida por los anticuerpos neutralizantes (AcN), la proteína gP5 del VAE se postuló en un primer momento como la proteína que media el reconocimiento del receptor y la adhesión. Sin embargo, el intercambio de la proteína gP5 del VAE con la del VSRRP o del LDV no altera el tropismo celular del virus mutante (Dobbe y col., 2001). Por otro lado, en los virus en los que se ha realizado el intercambio del ectodominio de la proteína M del VSRRP por aquel del VAE o del LDV aún conservan la habilidad de infectar macrófagos alveolares porcinos y no adquieren tropismo para las células susceptibles de los virus de los cuales derivan los ectodominios originales (Verheije y col., 2002). Esto sugiere que, en el caso de los arterivirus, las proteínas gP5 y M no son responsables de la unión virus-receptor. Debido a que las proteínas E, gP2b, gP3, y gP4 no son requeridas para la formación de las partículas virales, pero esenciales para que los virus sean infecciosos (Wieringa y col., 2004), se propuso que el complejo gP2b/gP4/gP3/(E) podría estar involucrado en el proceso de adhesión y entrada del VAE. Sin embargo es posible que el VAE utilice más de una molécula de adhesión para unirse a las células, al igual que ocurre con el VSRRP (Delputte y Nauwynck, 2004) e incluso que utilice diferentes moléculas de adhesión para unirse a diferentes células. Se demostró que la heparina podía reducir la infección del VAE en las células RK-13 (Asagoe y col., 1997), esta inhibición se debe a la interacción directa entre la heparina y el virus, más que a la interacción entre la heparina y la línea celular. Además, el tratamiento de las células RK-13 con heparinasa antes de la inoculación viral disminuye la infección del VAE en las células. Esta información sugiere que, al igual que en el caso del VSRRP (Delputte y col., 2002), una molécula similar a la heparina en la superficie de las células RK-13 podrían servir como 
receptor celular para el VAE. Sin embargo, el tratamiento con heparinasa de las células RK13 no reduce la infección viral por debajo del 13\%, incluso en presencia de una alta concentración de heparina (Asagoe y col., 1997). Esto implica que, como se demostró para el VSRRP (Delputte y col., 2002), otras moléculas de la superficie celular pueden servir como receptores para el VAE. Recientemente, la proteína CXCL16 equina (EqCXCL16) fue propuesta como una molécula candidata y un posible receptor de entrada celular para el VAE (Sarkar y col., 2016). En los caballos, el gen CXCL16 se encuentra en el cromosoma 11 (ECA11) y codifica una proteína glicosilada de transmembrana tipo I de 247 aa.

Poco se conoce sobre el mecanismo que usa el VAE para entrar a las células y desnudarse. En analogía con el VSRRP, que usa un mecanismo de endocitosis mediada por receptor dependiente de clatrina (Nauwynck y col., 1999), se asume que el VAE ingresaría por endocitosis mediada por receptor. Además, desde que se demostró que, en el caso del VSRRP, el pH bajo es necesario para la fusión entre la membrana endosomal y la envoltura, y el consiguiente desnudamiento viral (Nauwynck y col., 1999), se piensa que el VAE requeriría similares condiciones.

\subsection{Replicación del genoma y expresión de genes}

Una vez que el ARN viral se libera en el citoplasma, los arterivirus inician el ciclo replicativo en la célula huésped. El ciclo de replicación del VAE comienza con la traducción de las poliproteínas replicativas ( $R p R d$ ) seguido por la replicación genómica y la trascripción y traducción de las proteínas estructurales a través de ARNm sg (Snijder y Meulenberg, 1998). 


\subsubsection{Transcripción del genoma y procesamiento de la poliproteína en proteínas no}

estructurales

La traducción del genoma del VAE se inicia a través de un mecanismo dependiente de cap. La replicasa del VAE (RpRd) se expresa directamente desde el genoma viral en forma de poliproteína (pp) 1a y 1ab. La pp1a es traducida directamente desde el ORF1a, mientras que la traducción de ORF 1 b requiere un cambio de marco de lectura, justo antes de que termine la traducción del ORF1a (den Boon y col., 1991). Dos estructuras de ARN son considerados esenciales para el cambio eficiente de marco ribosomal: una secuencia "resbalosa" (7 nucleótidos) localizada "río arriba" del codón de stop de ORF 1a y una estructura pseudo-knot "río abajo" de la secuencia resbalosa (Snijder y Meulenberg, 1998). Una vez que ppla y pplab son sintetizados, se clivan 7 y 11 veces, respectivamente, por tres diferentes proteasas virales localizadas en las proteínas no estructurales (nsps) 1, 2 y 4 . En total, se originan 13 productos finales (nsps 1, 2, 3, 4, 5, 6, $7 \alpha, 7 \beta, 8,9,10,11,12$ ) (van Aken y col., 2006). Las nsps 1 a 8 son codificadas por el ORF 1a y las nsps 9 a 12 por el ORF 1b (van Dinten y col., 1999). Además de su rol proteolítico, la nsp 2, junto con la nsp 3, es necesaria y suficiente para inducir la formación de vesículas de doble membrana derivadas de la célula huésped (DMVs) a partir de membranas pareadas del retículo endoplasmático (Snijder y col., 2001). Una vez que se crean las DMVs, las proteínas no estructurales $2,4,7 \alpha, 7 \beta, 8,9$, y 10 se ensamblan a ellas para crear el complejo de replicación viral. Los dominios hidrofóbicos localizados en las nsp2, nsp3 y nsp5 median la asociación entre el complejo de replicación viral y la membrana intracelular (van der Meer y col., 1998). Como resultado de esta asociación se forma un 
andamio de membrana que dirigirá la replicación y la traducción de tanto el genoma viral como de los ARNm sg (Snijder y col., 2001). La formación de membranas pareadas y, consecuentemente de DMVs en la región perinuclear es una característica típica del VAE y de otras infecciones por arterivirus (Pol y col., 1997).

\subsubsection{Replicación del genoma}

La RpRd es la única proteína viral requerida para la replicación del genoma (Molenkamp y col., 2000). Sin embargo se desconoce si otras proteínas de la célula huésped están involucradas en la replicación del genoma. La RpRd copia las hebras genómicas (+) en hebras genómicas (-) de longitud completa y luego utiliza las hebras genómicas (-) como molde para sintetizar hebras genómicas (+). La síntesis del ARN del EAV es dirigida por el complejo de replicación viral asociado a la membrana de las DMVs y con la membrana intracelular, como se describió previamente.

\subsubsection{Transcripción de los ARN subgenómicos y expresión de las proteínas estructurales}

Las proteínas estructurales son originadas de la expresión de los ARNm sg. Al igual que para la replicación del genoma, la síntesis de ARNm sg es también dirigida por el complejo RpRd (Molenkamp y col., 2000). La transcripción de los ARNm sg ocurre en la misma localización celular y sigue los principios de la síntesis de ARN (den Boon y col., 1996; Godeny y col., 1998). La única diferencia es que la replicación del genoma es un proceso continuo, mientras que la transcripción de ARNm sg es un mecanismo discontinuo donde la RdRp debe detener la transcripción en un sitio y reiniciarla en otro (den Boon y col., 1995). Como resultado, se crean 17 secuencias pequeñas reguladoras de la transcripción (5'UCAAC3') de las cuales solo 6 se unirán a los ARNm sg dirigiendo la expresión de las 
proteínas estructurales. Las proteínas E, gP2b, gP3, gP4, gP5, ORF5a M y N, derivan de la expresión de los ARNm sg 2a, 2b, 3, 4, 5, 5a, 6 y 7, respectivamente (den Boon y col., 1991).

\subsection{Ensamble viral, brotación y liberación}

EI VAE adquiere su envoltura de las membranas internas de las células afectadas y no de la membrana plasmática, y su ensamble tiene lugar en la cara citoplasmática del RE y/o del complejo de Golgi (Magnusson y col., 1970). Las ocho proteínas estructurales (E, gP2b, gP3, gP4, gP5, ORF5a, M y N) son indispensables para la producción de la progenie viral infecciosa (Snijder y col., 1999 y 2003) pero sólo las proteínas estructurales gP5, M y N son esenciales para la formación de la partículas virales. Además de las proteínas gP5, M y N, factores desconocidos están involucrados en la formación de partículas del VAE, como se demostró en intentos fallidos de producción de partículas similares a virus a partir de la co-transfección de células con plásmidos que codifican para las proteínas gP5, M y N del VAE (Wieringa y col., 2004). Se piensa que, dado a que los heterodímeros gP5/M unidos por puentes disulfuro constituyen la matriz básica de la envoltura y ya que el transporte de las proteínas gP5 y M del VAE, desde el RE hasta el complejo de Golgi, depende de la formación del heterodímero gP5/M, esto último sería un prerrequisito para el ensamble viral (Snijder y col., 2003). Los dominios de los heterodímeros gP5/M citoplasmáticamente expuestos podrían interactuar con las nucleocápside una vez sintetizada.

Entonces, la nucleocápside del VAE brota dentro del lumen del RE o del complejo de Golgi y adquiere una membrana lipídica que acarrea proteínas de envoltura viral. Ya que las

proteínas E, gP2b, gP3 y gP4 son también proteínas integrales y están ancladas en la 
membrana lipídica del RE o del complejo de Golgi, la nucleocápside del VAE también adquiere esas proteínas de envoltura para la formación de las partículas virales. Finalmente, las partículas virales son transportadas desde los compartimentos intracelulares a la membrana plasmática desde donde se liberan por exocitosis. Luego de la liberación de las partículas virales, los puentes no covalentes entre la proteína gP3 y el heterodímero gP2b/gP4 se une en forma covalente formando el heterotrímero gP2b/gP4/gP3 (Wieringa y col., 2003a).

\section{ARTERITIS VIRAL EQUINA}

\subsection{Prevalencia de la enfermedad}

La AVE se restringe a los miembros de la familia Equidae. Ac anti-VAE fueron encontrados en caballos (incluidos ponies), burros y mulas. La enfermedad ocurre principalmente en caballos y ponies, pero se registraron signos clínicos en burros experimentalmente infectados (McCollum y col., 1995; Timoney y McCollum, 1993), y fue identificado un nuevo genotipo viral en burros de Chile (Rivas y col., 2017). AcN anti-VAE específicos se detectaron en 51 cebras en el parque nacional Serengeti, Tanzania (Borchers y col., 2005) pero aún no en cebras libres o de otros establecimientos (Paweska y col., 1997). Hay solo un reporte de la infección en alpacas con el VAE, a través de la detección del ARN del VAE a partir de tejidos fetales abortados, utilizando reacción en cadena de la polimerasa con transcripción reversa (RT-PCR) (Weber y col., 2006).

Investigaciones serológicas retrospectivas revelan que este virus estuvo presente prácticamente en todos los países antes de que se reconozca la enfermedad. Ac anti-VAE 
se encontraron en la mayoría de los países donde se realizó serología. Se hallo seropositividad en caballos de América del Norte y del Sur, Europa, Asia, África y Australia. Sin embargo, aún no se encontraron animales seropositivos al VAE en Islandia y Japón. La seroprevalencia de la infección por el VAE no solo varía entre los países sino también entre las razas de equinos. Las diferencias de seroprevalencia en las razas puede deberse a causas genéticas, pero también a diferencias de manejo. En los equinos infectados experimentalmente, la raza no tiene efecto aparente en la susceptibilidad a la infección o en el establecimiento del estado de portador (Balasuriya y col., 2013).

La diseminación global y la incidencia en aumento de los casos de AVE probablemente reflejan el intensificado movimiento nacional e internacional de equinos para competición y reproducción.

\subsection{Patogénesis de la infección con el VAE}

\subsubsection{Vías de infección y diseminación}

Las dos rutas principales son la respiratoria y la venérea.

La diseminación por aerosoles es el principal mecanismo de contagio del VAE durante un brote de enfermedad. En la fase aguda de la infección, una significativa cantidad de partículas virales son eliminadas a través de los fluidos respiratorios. El contacto directo y cercano aparentemente sería necesario para la transmisión aérea (Timoney, 1988).

La transmisión sexual es otra vía importante de infección viral. El virus puede ser transmitido por esta vía no sólo durante la fase aguda sino también a partir de sementales persistentemente infectados (Timoney y col., 1986 y 1987). Del 30 al 70\% de los sementales infectados se convierten en persistentemente infectados y eliminan el virus en 
su semen. El virus se asocia con la fracción de semen rica en esperma y no con la fracción fluida pre-eyaculatoria. La duración de la persistencia viral puede variar, algunos machos portadores dejan de eliminar el virus en el semen semanas a años después, sin evidencia de reversión hacia el estado de diseminador (Timoney y col., 1986 y 1987). EI VAE puede diseminarse artificialmente y con éxito a través de la inseminación artificial y el uso de semen fresco o congelado. Aproximadamente, entre el 85 y el $100 \%$ de las hembras seronegativas se convierten en infectadas cuando se aparean con machos persistentemente infectados o cuando son inseminados artificialmente con semen que contiene al virus. La transmisión venérea desde una hembra infectada en forma aguda a un macho negativo, si bien es probable, no fue documentada (Timoney y col., 1987).

La diseminación viral en semen también fue demostrada en burros (Paweska y col., 1996). El estado de portador nunca fue reportado en hembras, potrillos o machos sexualmente inmaduros. Las variaciones genéticas del VAE pueden ocurrir durante la infección persistente en los machos. (Balasuriya y col., 2004a) constituyendo un peligro potencial para nuevos brotes de AVE. Por lo tanto, los sementales portadores ocuparían un nicho especial en la epidemiología de las infecciones por el VAE, ya que no es solo un reservorio natural viral, sino que también colaboraría con la diversidad genética del VAE. Los brotes de AVE ocurren cuando una de estas variantes se transmite a un huésped susceptible. Por lo tanto, el porcentaje de machos portadores eliminadores activos determina la prevalencia de la infección por el VAE en las poblaciones equinas (Balasuriya y col., 2004a). 
Los caballos infectados en forma aguda diseminan el virus, aunque en pequeñas cantidades, a través de su orina, heces, secreciones corporales y vaginales (Timoney y McCollum, 1993). Los virus pueden ser detectados desde los 3 hasta los 14 días pi (dpi) en las secreciones respiratorias y desde los 5 hasta los 9 días en la orina (McCollum y col., 1971). El VAE también puede encontrarse en fetos abortados, membranas fetales, placenta y fluidos de la hembra que aborto (Timoney y McCollum, 1993). Estas fuentes de virus contribuirían a la transmisión por aerosoles así como a la transmisión indirecta a través de fómites.

EI VAE puede también, pero de forma menos común, ser transmitido por otras vías como el contacto indirecto con fómites contaminados (Timoney y McCollum, 1996). Un estudio reciente realizado por Broaddus y col. (2011) demostró que puede haber riesgo de transmisión del VAE en la transferencia de embriones, desde una hembra donante, previamente inseminada con semen infectado con el VAE (Broaddus y col., 2011; Timoney y col., 1987). También se registró la transmisión vertical trans-placentaria (Vaala y col., 1992).

\subsubsection{Patogénesis de la infección generalizada tras la infección por vía respiratoria}

La patogénesis de las cepas del VAE norteamericanas fueron estudiadas siguiendo la distribución de antígenos virales y lesiones en caballos infectados experimentalmente con la cepa virulenta H172S (KY63) del VAE de ingreso respiratorio (Crawford y Henson, 1972; Del Piero, 2000). A las 24 hpi, el virus infecta los macrófagos alveolares y los neumocitos con la presencia de antígenos virales localizados en su citoplasma (Wilkins y col., 1995). A las $48 \mathrm{hpi}$, el virus puede encontrarse en los linfonódulos satélites, especialmente en los 
linfonódulos bronquiales. Los antígenos virales son contenidos dentro de células estromales similares a dendritas y dentro de macrófagos de los senos de los nodos linfáticos (Jones y col., 1957). La viremia comienza luego de los 2-3 dpi dependiendo del animal y de la cepa viral. A los 3 dpi, el virus replica en los linfonódulos broncopulmonares, y en el endotelio y en los monocitos circulantes. Diferentes autores describen una viremia asociada a células con aislamientos esporádicos del virus a partir de la fracción acelular.

Se observó que los títulos más altos del VAE se asociaron a plaquetas, aunque títulos virales también significativos estaban presentes en los glóbulos rojos y la fracción de células blancas polimorfonucleares. EI VAE puede cosecharse de la capa leucocitaria del día 1 al 19 pi, mientras que del suero del día 1 al 9 pi (MacLachlan y col., 1996). Las infecciones experimentales con el VAE pueden causar viremia asociada a las células que dura varias semanas incluso cuando los Ac séricos seroneutralizantes se vuelven detectables (Fukunaga y col., 1981; Neu y col., 1987).

Sin embargo, la distribución sistémica del virus a través de la viremia resulta en la infección de los macrófagos y las células dendríticas de los tejidos linfoides asociados de varios sistemas de órganos. Aproximadamente, entre los días 6 y 8 pi, el virus se localiza dentro del endotelio y los miocitos de los vasos sanguíneos (McCollum y col., 1971). A partir del día 10 pi los antígenos del VAE se localizan en el endotelio, miocitos y pericitos perivasculares.

Pueden verse macrófagos marginales que contienen antígenos intracitoplásmicos del VAE, ocasionalmente asociados con células endoteliales infectadas. Aparentemente, el último 
sitio en ser invadido es el epitelio tubular renal. Se pueden encontrar abundantes antígenos víricos intracitoplasmáticos dentro de las células epiteliales tubulares, tanto en las morfológicamente intactas como en las necróticas (Del Piero, 2006). Después del décimo dpi, los antígenos del VAE han disminuido en todas las ubicaciones excepto en la túnica media de las pequeñas arterias musculares. El VAE infeccioso ya no es detectable en la mayoría de los tejidos después de los $28 \mathrm{dpi}$, con la excepción del tracto reproductivo de algunos sementales (Del Piero, 2000).

\subsubsection{Patogénesis del aborto tras la infección por vía respiratoria}

Timoney y McCollum (1993) demostraron que la infección transplacentaria, aunque es rara, puede ocurrir cuando las yeguas gestantes seronegativas están expuestas al VAE por vía respiratoria. Si la transmisión transplacentaria ocurre en los primeros meses de gestación, dará como resultado un aborto. En el caso de que una yegua preñada esté expuesta al virus en el último tercio de la gestación, el potro estará infectado congénitamente pero no se producirá el aborto (Vaala y col., 1992). Los antígenos del VAE en algunas ocasiones son detectables en los tejidos de fetos abortados y, cuando están presentes, se localizan dentro del endotelio de vasos sanguíneos viscerales, epitelio del timo, células esplénicas, y enterocitos (Johnson y col., 1991).

Coignoul y Cheville (1984) atribuyeron el aborto inducido por el VAE a la disminución del suministro de sangre al feto como consecuencia de la compresión de los vasos sanguíneos por edema endometrial, alteración del tono vascular por varios mediadores inflamatorios y / o lesión inducida por virus en el miometrio, en lugar de cualquier efecto directo del virus sobre el feto. Además, Del Piero (2000) informó que los niveles de progesterona en 
el suero de la yegua disminuyen constantemente desde las 48 a las 6 hs antes del aborto. La disminución de la producción de progesterona combinada con una liberación local de prostaglandinas, puede desencadenar el desprendimiento coriónico. Además, la isquemia inducida por vasculitis y trombosis también puede colaborar con la hipoxia y el desenlace fatal.

Como consecuencia del desprendimiento coriónico y la isquemia, puede producirse la expulsión de un feto, infectado o no infectado. Coignoul y Cheville (1984) indicaron que el virus en el feto puede reflejar solo la contaminación atribuible al aumento de la permeabilidad placentaria.

Sin embargo, se encontraron títulos del VAE considerablemente más altos en sangre fetal que en la materna y se detectó una abundancia relativa de antígenos virales en los tejidos fetales, en comparación con los maternos (MacLachlan y col, 1996) lo que indicaría que la presencia del VAE en los tejidos fetales no refleja simplemente la contaminación, sino que apunta hacia la infección por el VAE del propio feto. La infección y la patología fetal pueden activar el proceso normal del parto. Además, la muerte fetal por sí misma también puede liberar factores inhibitorios de la preñez en el miometrio, lo que puede llevar al aborto (Norwitz y col., 1999).

\subsubsection{Patogénesis de la infección por vía venérea}

Hasta ahora, no hay ningún estudio registrado sobre la patogénesis del VAE después de la exposición venérea. Sin embargo, se presume que el virus invade la mucosa vaginal y es transportado a los ganglios linfáticos locales donde probablemente se replica y se libera en el torrente sanguíneo y a la circulación linfática (Hedges y col., 1999). 


\subsubsection{Mecanismos de persistencia en sementales}

El VAE llega al tracto reproductivo masculino a través de la viremia que origina en una infección aguda y/o en un estado de portador. Se han demostrado dos situaciones posibles en el semental: un período de excreción de virus a corto plazo de 4-5 semanas y un estado de portador a largo plazo, después de la recuperación clínica, que persiste durante años o de por vida (Timoney y col., 1986 y 1987). En los sementales portadores, el VAE persiste exclusivamente en el tracto reproductivo y no en otros sitios. La ampolla de los conductos deferentes y otras glándulas sexuales accesorias se han identificado como los principales sitios de persistencia viral (Neu y col., 1987). El virus está asociado a la fracción rica en espermatozoides de la eyaculación y no suele estar presente en la fracción pre-espermática del semen (Timoney y McCollum, 2000).

Los mecanismos detallados de esta persistencia viral no están totalmente esclarecidos. Se ha propuesto que la persistencia viral puede ser el resultado de dos ingredientes esenciales: el primero podría ser que el virus tiene una estrategia única de replicación viral mediante la cual, en lugar de eliminar a su célula hospedadora, causa poco o ningún daño y por lo tanto puede residir en algunas células infectadas; el segundo es que la respuesta inmune no lo detecta o no puede eliminarlo (Oldstone, 1989 y 1991). Como el VAE en el tracto reproductivo de los sementales portadores puede transmitirse venéreamente a yeguas susceptibles, es evidente que el VAE no ha adquirido un tropismo restringido para el tracto reproductivo de los sementales (McCollum y col., 1988). Parece que la inmunidad humoral no previene el establecimiento y el mantenimiento de la infección por el VAE en el tracto reproductivo de los sementales. De hecho, se observó que los sementales 
portadores tienen títulos moderados a altos de Ac neutralizantes en suero (Timoney y McCollum, 1993) y que los sueros de sementales persistentemente infectados reconocen las proteínas virales gP5, N y M, mientras que el suero de yeguas, machos castrados y los sementales no persistentemente infectados solo reconocen las proteínas $M$ virales (MacLachlan y col., 1998).

La comparación entre aislamientos tomados a intervalos regulares de los mismos sementales naturalmente infectados, reveló variaciones oligonucleotídicas en el virus, que puede ser otro mecanismo para el establecimiento del estado portador (Murphy y col., 1992). Además, la disminución de los antígenos virales presentados en la superficie de la célula huésped podría enmascarar el VAE frente a los Ac específicos, permitiendo que el virus persista. Sin embargo, dado que las variantes virales que surgen en los sementales portadores aún pueden ser neutralizadas por AcN policlonales, parece poco probable que el escape inmune de mutantes del VAE desempeñe un papel significativo (Balasuriya y MacLachlan, 2004).

Otra hipótesis presentada para explicar la persistencia viral puede estar relacionada con el sitio inmunológicamente privilegiado que representa el tracto reproductivo masculino. Puede ser que el VAE en el tracto reproductor masculino sea inaccesible a los AcN circulantes o que los AcN solo puedan reducir parcialmente la replicación viral.

Existe evidencia convincente de que el establecimiento y mantenimiento del estado de portador en el semental depende de la testosterona. Cuando los sementales infectados persistentemente son castrados y tratados con testosterona, continúan eliminando virus 
al semen, mientras que los sementales castrados que recibieron un placebo dejan de eliminarlo (Little y col., 1991).

La investigación de potrillos prepuberales y puberales infectados mostró que el virus, después de la recuperación clínica, continúa replicando en el tracto reproductivo en una proporción significativa durante un período de tiempo variable. Esto ocurre tanto en ausencia de concentraciones circulantes de testosterona como en presencia de niveles equivalentes a los encontrados en los sementales sexualmente maduros. Sin embargo, la infección por el VAE persistente a largo plazo no se produjo en estos potros (Holyoak y col., 1993a).

El mecanismo por el cual la testosterona contribuye al establecimiento y mantenimiento de la infección persistente del VAE en los sementales aún no se ha determinado. Por lo tanto, queda por descubrir qué factor(es) del huésped o viral(es) contribuyen al establecimiento y mantenimiento de la infección persistente del VAE en los sementales. El análisis de dos sementales portadores y varios de sus descendientes masculinos no demostró una asociación significativa entre el haplotipo del Complejo Mayor de Histocompatibilidad (CMH) heredado y el estado de portador (Albright-Fraser, 1998). Además, el mecanismo que explica la eliminación espontánea del VAE en algunos de los sementales portadores no está claro.

Los hallazgos más recientes demostraron que el VAE, en los animales persistentemente infectados tiene un especial tropismo por los LT CD8 y los LB C21 (Carossino y col., 2017).

\subsection{Signos clínicos}


Aunque los casos clínicos confirmados de AVE han aumentado en los últimos años, la mayoría de las infecciones son subclínicas. La aparición de signos clínicos depende de la edad del animal, la vía de infección, la cepa del virus y la dosis viral. Los signos clínicos son generalmente más severos en animales de ambos extremos etarios y en caballos inmunodeprimidos o en mal estado.

Los signos clínicos generalmente se observan entre los días 1 y 10 pi (Cole y col., 1986) y pueden incluir cualquier combinación de los siguientes: hipertermia (2-12dpi), depresión, anorexia, conjuntivitis, lagrimeo, rinitis con secreción serosa a mucoide, edema de extremidades inferiores y rigidez de la marcha. También puede haber edema peri y supraorbital, en regiones medio ventrales, en escroto, en prepucio, en glándula mamaria y rash urticarial. Se observan menos frecuentemente: dificultad respiratoria severa, ataxia, erupciones mucosas, fotofobia, diarrea, ictericia y linfadenopatía submaxilar. En general, los animales se recuperan por completo (Timoney y McCollum, 1993 y 1996).

La tasa de aborto varía entre el $10-60 \%$ y un brote se puede caracterizar como "aborto epidémico". Las yeguas susceptibles infectadas por el VAE entre los 2 y 11 meses de gestación pueden experimentar aborto. Las edades de los fetos abortados pueden variar de 90 a 337 días. En el momento del aborto, las yeguas generalmente no muestran signos claros, pero es posible que previamente hayan manifestado anorexia, cojera, fiebre (41 $\left.{ }^{\circ} \mathrm{C}\right)$, conjuntivitis y secreción nasal antes del mismo (Timoney y McCollum, 1993). Normalmente, el aborto suele ocurrir durante la fase aguda de la infección o poco después (entre 1 y 3 semanas post exposición al virus). No hay evidencia de que las yeguas puedan abortar más de una vez debido a la infección por el VAE (Timoney y McCollum, 
1987). Experimentalmente, las yeguas inoculadas con el VAE abortaron entre los días 10 y 12 pi (Wada y col., 1996) mientras que yeguas sin inóculo viral pero en contacto con las que fueron inoculadas abortaron entre 23 a 57 días después de haberse iniciado la infección en las yeguas inoculadas (Cole y col., 1986).

Mientras que la mortalidad es muy rara en los caballos adultos sanos, es de casi un $100 \%$ en los potrillos recién nacidos. Por lo tanto, los equinos recién nacidos, no protegidos por inmunidad maternal, pueden morir repentinamente o poco después de demostrar signos respiratorios severos (Timoney y McCollum, 1993 y 1996). Los potrillos de algunos meses de la edad infectados pueden desarrollar una pulmonía o un neumoenteritis en algunos casos letales (Balasuriya y col., 2013).

Después de la infección experimental con el VAE y particularmente durante la etapa aguda, los sementales pueden experimentar un período de subfertilidad temporal, asociado a la reducción de la libido, al aumento de la temperatura escrotal y al cambio en calidad espermática (disminución de la motilidad, concentración y porcentaje de espermatozoides morfológicamente normales). Estas anomalías pueden persistir hasta 16 semanas, cuando recuperan los niveles de pre-exposición viral (Neu y col., 1992). La calidad del semen es normal en los sementales persistentemente infectados, a pesar de la presencia del VAE. La infección venérea de las yeguas por los sementales persistentemente infectados puede dar lugar a una disminución de la fertilidad en el ciclo inicial, pero no parece generar problemas subsecuentes de fertilidad (Timoney y McCollum, 1993).

\subsection{Hallazgos patológicos}


Las distintas cepas del VAE difieren en virulencia y, consecuentemente, inducen lesiones que difieren en severidad (McCollum, 1981). Los datos sobre lesiones macro y microscópicas de los que se dispone corresponden a estudios de infecciones naturales y experimentales con cepas virulentas responsables de brotes de VAE.

\subsubsection{Lesiones macroscópicas}

Las lesiones tanto macro como microscópicas reflejan el extenso y considerable daño vascular a nivel de arteriolas y arterias pequeñas, vasos linfáticos, venas y capilares. El edema, la congestión y las hemorragias en los tejidos subcutáneos, los ganglios linfáticos y las vísceras son las lesiones macroscópicas más frecuentemente observadas. Las cavidades del cuerpo pueden contener cantidades moderadas a abundantes de exudado peritoneal, pleural y pericárdico, de tonalidad clara a amarillenta. La congestión, la linfoadenomegalia, el edema, y las hemorragias se pueden observar a lo largo del colon y ciego. Los pulmones presentan secreciones abundantes y aumentan de peso, con edema, enfisema y neumonía intersticial. Estos últimos hallazgos son más frecuentes en neonatos infectados. Cuando la congestión y las hemorragias están presentes, los pulmones pueden observarse rojizos en forma difusa o con focos múltiples que le otorgan un aspecto atigrado. En los casos fatales de la enfermedad en potrillos se han descrito tanto enteritis como infartos del bazo. La superficie endometrial uterina de las yeguas que han abortado puede encontrarse tumefacta y congestionada, a veces con hemorragias (Del Piero, 2006; Prickett y col., 1972).

\subsubsection{Lesiones histopatológicas}


En general, las lesiones histopatológicas se observan en muchos órganos, pero los vasos sanguíneos son el blanco principal del VAE. Las lesiones vasculares sutiles incluyen infiltración linfocítica e hipertrofia endotelial. Los cambios vasculares severos comprenden:

- Vasculitis con necrosis fibrinoide de la túnica media,

- Infiltración linfocítica linfática vascular y perivascular,

- Pérdida de endotelio,

- Formación de trombos fibrinocelulares estratificados con infarto del tejido asociado.

Los vasos capilares a menudo son obliterados por las células endoteliales tumefactas, trombos plaquetarios o neutrófilos (Estes y Cheville, 1970).

Las descripciones detalladas de los cambios histopatológicos en diversos órganos fueron proporcionadas a partir de estudios con equinos experimentalmente infectados con cepas norteamericanas del VAE (del Piero, 2006; Jones y col., 1957; Prickett y col., 1972). El tipo y la severidad de las lesiones descritas y los órganos afectados varían de un animal a otro y de una cepa viral a otra. En los pulmones son lesiones comunes la neumonía intersticial leve a severa; caracterizada por infiltración alveolar con macrófagos y neutrófilos, formación de membranas hialinas y presencia de alvéolos cargados de secreciones. Además, frecuentemente se observan arteritis y flebitis pulmonares. Dentro de los órganos linfoides, la necrosis linfoide folicular, el edema y la hemorragia leves con eritrofagocitosis macrofágica son hallazgos comunes. La vasculitis cardiaca con necrosis de los miocitos se observa en raras ocasiones. En el hígado puede observarse vasculitis portal 
que consiste en una infiltración celular inflamatoria severa que erosiona la placa periportal hepatocelular. Se observa esporádicamente la distensión de los linfáticos de la submucosa del intestino grueso , con necrosis leve de las criptas y de la lámina propia. La glándula adrenal ocasionalmente muestra vasculitis multifocal, hemorragias e infartos. Las lesiones renales ocurren cuando la infección está en una etapa avanzada y consisten en necrosis tubular, nefritis intersticial linfocítica, desorganización glomerular e hipercelularidad. La dermis está implicada en algunos casos con vasculitis, trombosis y, en raras ocasiones, dermatitis ulcerosa. El sistema nervioso no se afecta generalmente, aunque la necrosis vascular cerebral se haya reportado en fetos. El lámina propia y la submucosa uterinas pueden encontrarse edematosas con la infiltración de neutrófilos y de macrófagos. Los vasos sanguíneos uterinos muestran tumefacción endotelial, mientras que pueden hallarse miocitos necróticos (Jones y col., 1957; Coignoul y Cheville, 1984).

Los potrillos pre-púberes y púberes experimentalmente infectados, sacrificados entre el 7mo y el 14to dpi viral, presentan vasculitis necrotizante en los testículos, epidídimos, vasos deferentes, ampolla seminal, próstata y glándulas bulbouretrales. Esta vasculitis está caracterizada por necrosis fibrinoide severa de las arterias musculares pequeñas, con edema y hemorragia. En potros examinados entre los días 28 y 180 pi, se encontró infiltrado linfocítico en la lámina propia y túnica muscular del epidídimo y de las glándulas genitales accesorias. Uno de los potros pre-púberes, infectado durante 15 meses, presentaba marcada infiltración linfoplasmocítica de la ampolla seminal (Holyoak y col., 1993b). 
Los fetos y las membranas fetales a menudo son expulsados, ya sea autolisados o bien preservados. Las lesiones en el feto, cuando están presenten, consisten en un infiltrado linfocítico perivascular y neumonía intersticial. Esporádicamente, se observa vasculitis del atlantocorion, cerebro, hígado, bazo y pulmón. En los potros, donde prevalecen las lesiones pulmonares, puede observarse un síndrome neumoentérico con los cambios patológicos en las criptas intestinales, en los vasos sanguíneos de la mucosa intestinal y en los tejidos linfoides gastrointestinales asociados; los infartos de ciego y de colon son raros (Golnik y col., 1981; Johnson y col., 1991).

\subsection{Signos clínicos y patología de la infección con cepas de baja patogenicidad}

Generalmente, los brotes de AVE causados por cepas de baja patogenicidad pueden ser caracterizados por fiebre, anorexia, depresión, edema de los miembros, conjuntivitis con lagrimeo, rinitis y secreción nasal, urticaria, aborto y riesgo de muerte en potros (Hans y col., 2008). En un brote búlgaro, por ejemplo (Chenchev, 2008), los primeros signos clínicos fueron depresión, anorexia y conjuntivitis. La temperatura corporal máxima registrada fue de $40.2{ }^{\circ} \mathrm{C}$. En algunos animales se observó dermatitis. Los animales enfermos presentaron retardo del crecimiento y frecuentemente infecciones bacterianas secundarias, como salmonelosis y neumonía. El porcentaje de aborto fue del $18 \%$. Los abortos se observaron principalmente durante la primera parte de la gestación y las yeguas se recuperaron sin tratamiento veterinario. Los cambios patológicos incluyeron: cianosis de la piel; lesiones típicas de neumonía intersticial con múltiples masas nodulares en los pulmones de color rosado. La tráquea y los bronquios presentaron ocasionalmente líquido espumoso. 


\subsection{Inmunidad}

Puesto que la infección natural del VAE ocurre a partir del tracto respiratorio o reproductivo, la respuesta innata de la mucosa que recubre las vías respiratorias y genitales proporciona la primera línea de defensa. Aunque poco se sabe de la respuesta inmune innata evocada por el VAE, se piensa que no difiere en gran medida de la inducida por otros virus (Balasuriya y MacLachlan, 2004). La respuesta inmune adaptativa se divide en humoral y mediada por células. Se han detectado Ac post infección mediante las pruebas de fijación del complemento (FC) y de seroneutralización (SN). El pico de los Ac anti-VAE ocurre entre las 2-3 semanas pi y estos persisten por 8 meses. Según Chirnside (1992) los AcN inducidos por la infección natural o experimental o vacunales, presentan un pico en el plazo de 1-2 meses, y permanecen por varios años (posiblemente de por vida). Con la excepción de los sementales persistentemente infectados, el VAE se elimina por 28 días después de que la infección, situación que finaliza con la aparición de AcN en el suero (Timoney y McCollum, 1993). Los sementales portadores tienen generalmente títulos particularmente altos de AcN (Timoney y McCollum, 1993 y 2000; Balasuriya y MacLachlan, 2004). Los AcN protegen a los animales contra la re-infección (McCollum, 1970; 1976 y 1986).

Los Ac maternales aparecen en el neonato después de la ingestión de calostro y son detectables en el potrillo hasta los 2 a 6 meses de edad. Se estima que la vida media promedio de los Ac maternales es de 32 días (Hullinger y col., 1998).

El análisis de immunoblotting demostró que los sueros de los animales infectados reconocen con predominancia a la proteína $M$ de envoltura, mientras que el 
reconocimiento de las proteínas gP5 y N es variable, mientras que las demás proteínas son raramente reconocidas. Los animales persistentemente infectados y los equinos inmunizados artificialmente desarrollan Ac específicos para la gP3 (100 y 81\%, respectivamente), mientras que estos Ac sólo se encontraron en entre un 16 y 22\% de los animales que estuvieron en contacto con el virus una sola vez. Estos resultados sugieren claramente que la gP3 es inmunogénica pero solamente después de la exposición repetida (Balasuriya y MacLachlan, 2004). Varios laboratorios han desarrollado AcN monoclonales del VAE y todos reconocen la proteína gP5 mediante WB y/o inmunoprecipitación (Glaser y col., 1995). Varios estudios han demostrado que el ectodominio (aa 19-116) de la proteína gP5 es immunodominante y que, más específicamente, los residuos aminoacídicos 49 y 61; los aa comprendidos entre 67-90 y entre 99-106 ya que son los sitios para la inducción de AcN (Balasuriya y col., 1993; 1995b y 1997). En conjunto, estos estudios demostraron que el ectodominio de la proteína gP5 contiene los determinantes de neutralización del VAE (Balasuriya y col., 1997 y 2004b). El mecanismo por el cual los Ac actúan para neutralizar la contagiosidad viral no se conoce con claridad, pero se demostró que la adición del 10\% de complemento de cobayo aumenta su sensibilidad, demostrando que la neutralización del VAE es dependiente del complemento (Fukunaga y col., 1994). La inmunidad mediada por células anti-VAE aún no se conoce con total profundidad. La detección de precursores de LT CD8+ en animales infectados con el VAE indicaría que la inmunidad mediada por células puede desempeñar un papel importante para suprimir la viremia. Inicialmente ocurre una activación pi de los LT CD8+ y CD4+, mientras que a medida que transcurren los días se observa un aumento en el cociente de CD8+/CD4+, lo 
que podría indicar que los LT CD8+ serían responsables de la lisis de las células blanco infectadas con el VAE (Castillo-Olivares y col., 2003).

Teniendo en cuenta que la replicación del VAE en sementales crónicamente infectados persiste durante varios meses o años, a pesar de los altos niveles circulantes de AcN; y que las infecciones experimentales con el VAE pueden causar un viremia asociada a células que se prolonga varias semanas después de que los $\mathrm{AcN}$ del suero sean perceptibles; puede deducirse que el VAE, así como los otros miembros de su familia, presenta alguna estrategia para escaparse de la Inmunidad del huésped.

\subsection{Diagnóstico}

\subsubsection{Diagnóstico clínico}

EI VAE no puede diagnosticarse basándose únicamente en hallazgos clínicos o patológicos. Por lo tanto, se requiere confirmación de laboratorio para aislar el virus o titular los AC anti-VAE. Los signos clínicos orientativos de AVE incluyen fiebre, depresión, edema, conjuntivitis, secreción nasal y aborto. Los diagnósticos diferenciales son numerosos e incluyen otras infecciones virales como el herpes virus equino (HVE) 1 y 4, rinovirus equinos, anemia infecciosa equina (AIE) y peste equina africana. También enfermedades de naturaleza no infecciosa como urticaria, shock, púrpura hemorrágica y síndrome urémico hemolítico pueden parecerse a la infección por el VAE (Del Piero, 2000).

\subsubsection{Detección del virus, componentes virales y anticuerpos}

Cuando se sospecha de AVE el aislamiento del virus se debe realizar a partir de frotis nasofaríngeos y conjuntivales, líquido de lavado broncoalveolar y muestras de sangre con anticoagulante (Timoney y McCollum, 1993). Para optimizar las posibilidades de 
aislamiento del virus, las muestras pertinentes deben obtenerse tan pronto como sea posible después del inicio de la fiebre en los caballos afectados. En casos de mortalidad en potros jóvenes o animales mayores, se puede intentar el aislamiento viral a partir de una variedad de tejidos, especialmente nódulos linfáticos entéricos, pulmones, hígado y bazo (McCollum y col., 1971). En los brotes de aborto relacionado con el VAE y casos de potrillos muertos, placenta, fluidos y tejidos fetales (especialmente de los pulmones) son fuentes de virus (Timoney y McCollum, 1993). A menudo, un feto abortado no contiene niveles detectables de antígenos del VAE; es más probable el aislamiento viral a partir de una PCR utilizando como muestra tejido endometrial.

La presencia del VAE en fluidos corporales, muestras de tejido, sangre, semen y placenta generalmente se puede detectar mediante aislamiento del virus en cultivos celulares. Las muestras más apropiadas para el aislamiento de animales vivos son hisopos nasofaríngeos, hisopos conjuntivales y muestras de sangre citratada o ácido etilendiaminotetracético (EDTA), para la separación de las células de la capa leucocítica. El aislamiento del VAE actualmente se realiza utilizando la línea celular RK-13. El aislamiento viral es la prueba de oro estándar actual, aprobada por la Organización Mundial de Sanidad Animal (OIE), para la detección del VAE en el semen de sementales. El efecto citopático (ECP) y el título viral pueden variar significativamente entre las líneas celulares. Los ECP virales en células infectadas con el VAE aparecen dentro de 2-6 días y se caracterizan generalmente por redondeamiento celular, vacuolización, refracción y desprendimiento del soporte de cultivo. Se debe considerar que, si bien la gran mayoría 
de los aislamientos del VAE se realizan en el primer paso en el cultivo celular, una minoría solo se hará evidente durante el segundo pasaje o en los sucesivos.

Los métodos inmunocitoquímicos (Little y col., 1995), como la inmunofluorescencia indirecta (Crawford y Henson, 1972) o la inmunomarcación con avidin-biotin-peroxidasa (Del Piero y col., 1997) también se han usado para detectar antígenos virales en membranas fetales, placenta, tejidos fetales (especialmente pulmones, nódulos linfáticos, hígado e intestino) y tejidos recolectados de animales infectados experimentalmente (como pulmones, nódulos linfáticos, corazón, hígado, bazo, intestino y testículos o útero), así como de biopsias de piel de caballos infectados.

La técnica RT-PCR puede detectar ácidos nucleicos virales en muestras clínicas como fluidos corporales (incluido el semen) o tejidos recogidos en la necropsia (membranas fetales, placenta, pulmones, nódulos linfáticos, corazón, hígado, bazo, intestino, testículos o útero). La RT-PCR es una técnica de diagnóstico potente y sensible, incluso si se debe tener en cuenta la variabilidad genética de las distintas cepas del VAE. Se recomienda el uso de PCR múltiples usando diferentes pares de cebadores para reducir los falsos negativos (Balasuriya y col., 1998).

Finalmente, los sementales seropositivos sin historial de vacunación o con certificado que acredita que el animal era seronegativo hasta antes de la primera vacunación, deben ser examinados para determinar el estado del portador. El estado de portador de un semental puede determinarse mediante RT-PCR utilizando como muestra la fracción rica en esperma o mediante el servicio de dos yeguas seronegativas con el objeto de evaluar en ellas el desarrollo de Ac anti-VAE. Si las yeguas se seroconvierten cuatro semanas después 
del servicio, entonces el virus estaba presente en el semen y el semental es diagnosticado como portador (test mating).

Se han utilizado una variedad de pruebas serológicas, que incluyen virus neutralización (VN), fijación del complemento (FC), inmunodifusión en gel de agar (IDGA), enzimoinmunoanálisis (ELISA) e inmunoensayo con microesferas fluorescentes (MIA) para detectar Ac anti-VAE. En casos agudos, se debe observar un aumento de cuatro veces en los títulos de Ac de suero pareado. La prueba de VN se considera el "estándar de oro" para la detección y titulación de Ac anti-VAE y, actualmente, es la única prueba validada aceptada internacionalmente. Aunque, la prueba de VN es muy sensible y precisa, tiene varias desventajas: es costosa, laboriosa y lleva mucho tiempo. Además, los resultados pueden variar entre los laboratorios cuando no se presta la atención adecuada a la estandarización de ambos reactivos de prueba y el procedimiento. Además, algunos sueros cuando se usan sin diluir o a diluciones bajas, pueden inducir citotoxicidad en los cultivos celulares posiblemente conduciendo a una mala interpretación. Además, la prueba de VN no puede diferenciar la respuesta de Ac de los caballos vacunados de los naturalmente infectados. Para superar estas desventajas, se han desarrollado varios ELISA. Aunque aún no están validados tan ampliamente como la prueba de VN, algunos ELISA parecen ofrecer una especificidad comparable y una sensibilidad cercana a la equivalente VN (Cho y col., 2000). La prueba de FC es menos sensible que los ensayos antes mencionados, pero se puede usar para diagnosticar infecciones recientes.

\subsection{Medidas recomendadas ante la sospecha de AVE}

$\underline{\text { Notificación a las autoridades }}$ 
Los veterinarios que detecten un caso de AVE deben seguir las pautas nacionales y/o locales para la notificación y las pruebas de diagnóstico correspondientes.

La AVE debe notificarse ante la OIE. Los requisitos para la notificación de la enfermedad a las naciones miembros de la OIE y las pautas de importación/exportación pueden consultarse en el Código Sanitario para los Animales Terrestres de la OIE [http://www.oie.int/esp/normes/mcode/es_sommaire.htm].

\subsection{Control de la enfermedad}

Deben aislarse los animales infectados en forma aguda para evitar la transmisión mediante secreciones y excreciones. Es importante tomar precauciones para evitar la propagación del virus por medio de fómites. El VAE es rápidamente inactivado por los detergentes, desinfectantes comunes y los solventes lipídicos. No existe ningún tratamiento específico disponible. Sin embargo, la enfermedad es autolimitante, salvo en potrillos donde puede agravarse el cuadro. En los casos agudos se debe realizar un tratamiento sintomático y cuidados intensivos en los casos graves. La vacunación también puede ayudar a contener brotes.

Con buen manejo y vacunación, la transmisión venérea puede ser controlada. Para proteger a las yeguas preñadas del aborto, deben quedar separadas de los otros animales y ubicadas en pequeños grupos, de acuerdo con la fecha prevista de parición. Los caballos recién adquiridos deben ser aislados durante 3-4 semanas. La vacunación evita que los sementales no infectados, se conviertan en portadores persistentes. Los sementales seronegativos deben ser vacunados previos al inicio de la temporada de reproducción. En Europa y EEUU los potrillos reciben la vacuna a partir de los 6 meses y hasta el año de 
edad. Los sementales portadores son identificados y se aparean sólo con yeguas vacunadas o naturalmente seropositivas. De manera similar, el semen que contiene VAE se debe utilizar sólo en estas yeguas. Debido a que las yeguas primovacunadas pueden eliminar virus de campo durante un corto periodo de tiempo pos exposición, deberían aislarse de animales seronegativos, especialmente yeguas preñadas. Las yeguas naturalmente infectadas y aquellas que no son primo vacunadas son aisladas durante 2448 hs una vez servidas, para proteger a otros animales de los virus presentes en el semen. Los sementales portadores deben ser alojados donde puedan estar físicamente separados de los caballos no infectados (Balasuriya y col., 2013). EI VAE es sensible a la luz solar y a la desecación, esto explica porque sementales no infectados han estado alojados cerca de portadores durante años sin infectarse. Se deben implementar buenas medidas de higiene y desinfección de los fómites durante la reproducción asistida o recolección de semen. Aún no existe un método probado para eliminar la condición de portador en los sementales aunque algunos métodos experimentales pueden ser prometedores. En Nueva Zelanda, para erradicar la AVE se utiliza: la denuncia obligatoria (identificando a los sementales portadores), toma de muestra anual de toda la población equina para actualizar la prevalencia, y vacunación selectiva. No hay indicios de que el virus de arteritis equina sea zoonótico (Balasuriya y col., 2013).

\subsection{Situación en Argentina}

En nuestro país se detectaron Ac a partir de 1984 sin casos clínicos (Nosetto y col., 1984).

En el año 1994 las autoridades sanitarias argentinas (SENASA: Servicio Nacional de Sanidad y Calidad Agroalimentaria) autorizaron la importación de padrillos de razas 
reguladas por el Stud Book Argentino desde países con enfermedad declarada. Los animales ingresantes deberían cumplir ciertas exigencias, como la ausencia de Ac determinada por $\mathrm{VN}$ en su país de origen, de animales no vacunados o bien que aquellos que hubieran sido vacunados y que demostraran no ser transmisores del virus por semen. Asimismo, los machos enteros serológicamente positivos deberían ser sometidos a una prueba biológica. En noviembre de 1997, se amplió la autorización para la importación definitiva de equinos (de la Sota y col., 2005). Hasta el año 1998 nuestro estatus sanitario, declarado ante la OIE, era de enfermedad no señalada de denuncia obligatoria y cuarentena en frontera. Las importaciones de material reproductivo y animales en pie desde los países que tenían la enfermedad se autorizaban solo ad referéndum de la correspondiente certificación, extendida en origen por la autoridad veterinaria oficial. Posteriormente a esa fecha, al iniciarse en nuestro país el control oficial efectuando la prueba diagnóstica al ingreso, se detectaron animales no vacunados y semen importado positivos para AVE, lo que motivo su correspondiente reexportación o destrucción, respectivamente. Como ya fue mencionado, uno de los puntos más importantes de la enfermedad es que hasta un $60 \%$ de los padrillos infectados pueden transformarse en portadores crónicos, y de esta manera, diseminar el virus mediante el servicio natural o la inseminación (Chirnside, 1992). Hasta ese momento, la certificación oficial de padrillos y de semen, tanto nacional como importado, como prerrequisito para la inclusión en el registro de servicios y el diagnóstico de dos muestras pareadas para determinar seroconversión hacía que los animales importados fueran retenidos en aislamiento en el Lazareto Capital durante 14 días ya que la vacunación no estaba permitida. Sí se admitía 
el ingreso de animales vacunados con la certificación extendida en origen por la autoridad veterinaria local.

En 2001, el virus se aisló por primera vez a partir de muestras de semen, sin detectarse sintomatología atribuible a esta virosis (Echeverría y col., 2003), donde se aisló ente otras la cepa LP/01. En el año 2010 se registró un brote con enfermedad respiratoria, aborto, muerte de potrillos e infección en machos enteros originado por el uso de pajuelas importadas infectadas. La prevalencia se restringió a las razas de caballos de deporte. De uno de estos animales se logró aislar una nueva cepa del virus denominada GLD-LP-ARG. Este acontecimiento hizo que cambiara el estado sanitario de la enfermedad en el país, y del mismo modo se autorizó la vacunación, que hasta el momento estaba restringida por no permitir la distinción serológica entre animales vacunados y naturalmente infectados. Como consecuencia del brote 22 padrillos persistentemente infectados fueron castrados.

A comienzos del 2015 SENASA realizó una vigilancia epidemiológica en 47 establecimientos con antecedentes sanitarios de AVE y en función a su actividad reproductiva, se encontraron 34 animales positivos de los cuales 33 correspondían a animales vacunados pero uno de ellos, nacido y criado en el país, no había recibido vacunación alguna. En el haras del cual provenía este animal se analizaron todos los animales susceptibles al VAE no registrando signos clínicos pero si una prevalencia serológica cercana al 60 \%, lo que conllevó a la interdicción del establecimiento.

Un estudio posterior de seguimiento de ingreso y egreso de todos los animales del haras interdicto entre abril y diciembre de 2015 , reveló que el $29 \%$ de los animales no pudieron ser localizados lo que perjudica el seguimiento epidemiológico y gestión sanitaria frente a 
este evento. Como medida preventiva SENASA procedió a la castración de todos los machos menores de dos años (20).

Los padrillos y su semen criopreservado constituyen el reservorio del VAE, lo que asegura su persistencia en la población de caballos en todo el mundo, provocando nuevos brotes como el que ocurrió en Argentina en el año 2010. Estos resultados refuerzan la importancia de vigilar cuidadosamente los padrillos persistentemente infectados, así como las pajuelas de semen, por aislamiento viral, RT-PCR o el test mating, de acuerdo con las regulaciones nacionales.

El laboratorio de Virología de la Facultad de Ciencias Veterinarias de la Universidad Nacional de La Plata es uno de los 4 laboratorios habilitados en Argentina por el SENASA para el diagnóstico de AVE, no sólo por serología sino también para el procesamiento de las muestras para aislamiento viral, técnicas de RT-PCR y caracterización genética. Las consecuencias económicas directas atribuibles a esta virosis son debidas a abortos, muerte perinatal, cierre de mercados por infección persistente de animales en pie o semen y disminución del valor comercial del portador persistente. Por lo cual, es indispensable el envío de muestras a los laboratorios acreditados y el control pertinente de las autoridades sanitarias. Para eso se recomienda realizar serología anual de los padrillos, inseminar con material certificado libre de virus, mantener aislados animales con signología respiratoria o abortos y comunicar a la autoridad de SENASA regional. Aunque la enfermedad está bastante circunscripta luego del brote de abortos del año 2010, el riesgo potencial de diseminación futura, nos lleva a desarrollar metodologías de 
diagnóstico que permitan implementar estrategias de control eficientes para evitar su diseminación.

El hecho que algunas cepas del VAE no provoquen sintomatología asociada mientras que otras cursen con tormentas de abortos genera el interrogante de plantear si existe una relación entre los niveles de inducción de muerte celular y el grado de patogenicidad inducido por las distintas cepas virales.

\section{APOPTOSIS}

\subsection{Generalidades}

El término apoptosis fue utilizado por primera vez en un artículo de Kerr, Wyllie y Currie en 1972 para describir "una forma morfológicamente diferente de muerte celular", sin embargo ciertos componentes del proceso ya habían sido descritos muchos años atrás. La palabra apoptosis proviene del griego antiguo (apo: separar y ptosis: caer) y se empleó para describir la caída de las hojas de los árboles. En biología celular, se utilizó para referir un tipo de muerte celular programada caracterizada por la formación de pequeñas vesículas esféricas, denominadas cuerpos apoptóticos, que se separan de las células que están atravesando este proceso (Kerr y col., 1972). En la apoptosis las células mueren a través de un proceso secuencial, ordenado y finamente regulado en respuesta a una variedad de estímulos o factores, tanto extra como intracelulares (Dubin y Stooppani, 2000; Cooper y Hausman, 2009).

La apoptosis se considera un componente vital de varios procesos, incluyendo: el recambio celular, el desarrollo y funcionamiento normal del sistema inmunitario, la atrofia 
hormona-dependiente de órganos, el desarrollo embrionario y la muerte inducida por agentes químicos (Norbury y Hickson, 2001). La apoptosis inapropiada (poca o demasiada) es un factor desencadenante de muchas condiciones patológicas animales y humanas, incluyendo las enfermedades neurodegenerativas, trastornos autoinmunes y varios tipos de cáncer.

Los conocimientos actuales de los mecanismos que llevan adelante el proceso de apoptosis en células mamíferas existen gracias a las investigaciones llevadas a cabo durante el desarrollo de un nematodo: Caenorhabditis elegans (Horvitz, 1999). En este animal, que se origina con 1090 células somáticas, 131 de éstas sufren apoptosis para dar lugar al gusano adulto. Muchos de los genes que controlan la apoptosis han sido identificados, y los mecanismos moleculares detrás de éstos han demostrado ser conservados evolutivamente (Metzstein y col., 1998).

Además de la apoptosis, que implica la eliminación celular genéticamente determinada, existen otras formas de muerte celular programada: por un lado la autofagia, necroptosis y netosis (independientes de caspasas); y por otro lado la piroptosis, cornificación y anoikis (dependientes de caspasas) (Formigli y col., 2000; Sperandio y col., 2000; Debnath y col., 2005; Kolb y col., 2017; Nagata, 2018). Es fundamental distinguir la apoptosis de la necrosis, dos procesos que pueden ocurrir independientemente, secuencialmente o simultáneamente (Hirsch, 1997; Zeiss, 2003). En algunos casos es el grado del estímulo lo que determina si las células mueren por apoptosis o necrosis. A bajas dosis, el calor, la radiación, la hipoxia y los medicamentos citotóxicos pueden inducir apoptosis; pero estos 
mismos estímulos pueden dar lugar a necrosis a dosis altas. Las principales características distintivas de estos dos tipos de muerte celular se observan en la siguiente Tabla.

\begin{tabular}{|c|c|}
\hline Apoptosis & Necrosis \\
\hline Genéticamente programada & Accidental \\
\hline Fisiológica/Patológica & Patológica \\
\hline Dependiente de energía & Independiente de energía \\
\hline Afecta células individuales o en pequeños grupos & Afecta gran número de células \\
\hline Reducción del tamaño celular & Aumento del tamaño celular \\
\hline Núcleo: picnosis y cariorrexis & Núcleo: picnosis, cariorrexis y cariolisis \\
\hline Citoplasma contenido (cuerpos apoptóticos) & Citoplasma liberado al espacio intersticial \\
\hline Inflamación: ausente & Inflamación: presente \\
\hline
\end{tabular}

Tabla 1: Cuadro comparativo de Apoptosis y Necrosis celular. Se observan las principales diferencias entre estos dos procesos de muerte celular, desde el punto de vista fisiológico y morfológico.

Aunque la apoptosis y la necrosis son procesos diferentes, existe una superposición entre ellos, ya que representan expresiones morfológicas de una red bioquímica descripta como el "continuum apoptosis-necrosis" (Zeiss, 2003). Se reportaron dos circunstancias clave para convertir un proceso apoptótico en curso en un proceso necrótico: una de ellas es la disminución de la disponibilidad de caspasas y la otra es la depleción de ATP intracelular (Leist y col., 1997; Denecker y col., 2001).

\subsection{Muerte celular por apoptosis}

\subsubsection{Cambios morfológicos}

Gracias a la microscopía óptica y electrónica se han podido identificar los cambios fenotípicos que se producen durante la apoptosis (Hacker, 2000; Jayakiran, 2015). En el inicio del proceso, la contracción celular (células más pequeñas) y la picnosis (núcleo 
denso) son visibles por microscopía óptica (Kerr y col., 1972). El budding es el proceso de fragmentación celular en cuerpos apoptóticos. Estos últimos consisten en estructuras citoplasmáticas con o sin organelas, delimitados por una membrana plasmática intacta. Generalmente no hay reacción inflamatoria asociada con la eliminación celular en la apoptosis, ya que:

1) las células apoptóticas no liberan sus constituyentes celulares en el tejido intersticial;

2) son fagocitadas rápidamente, por macrófagos o células parenquimatosas, previniendo la necrosis secundaria subsecuente; $y$,

3) las células fagocíticas no producen citoquinas (Savill y Fadok, 2000; Kurosaka y col., 2003).

\subsubsection{Cambios bioquímicos}

Las caspasas se encuentran normalmente como proenzimas (inactivas) en las células y una vez activadas pueden estimular otras procaspasas: lo que permite la creación de una “cascada proteolítica". Algunos procaspasas también pueden "autoactivarse". Este mecanismo en cascada conduce a una muerte celular rápida (Jayakiran, 2015).

Las caspasas son capaces de escindir proteínas en residuos de ácido aspártico. Las principales caspasas han sido identificadas y clasificadas en tres grupos, según Cohen (1997) y Rai y col. (2005):

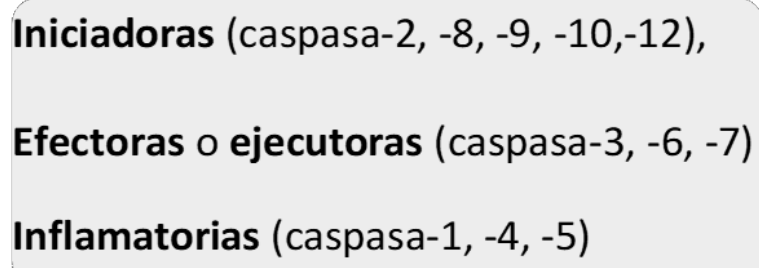


Otras caspasas no clasificadas en los grupos anteriores son: la caspasa-11, que se relacionó con apoptosis y liberación de citoquinas durante el shock séptico; la caspasa-13, que se encuentra sólo en el bovino, y la caspasa-14, que está altamente expresada en tejidos embrionarios, pero no en tejidos adultos (Hu y col., 1998; Nakagawa y col., 2000, Koenig y col., 2001; Kang y col., 2002).

La fragmentación del ADN por endonucleasas (activadas por las caspasas efectoras) da lugar a fragmentos típicos de 180 a 200 pares de bases (pb) (Bortner y col., 1995; Jayakiran, 2015). Este último evento origina una "escalera de $A D N "$ que se puede visualizar mediante electroforesis en gel de agarosa teñido con bromuro de etidio y sometido a iluminación ultravioleta.

Otra característica bioquímica es la expresión de marcadores en la superficie celular para el reconocimiento temprano y fagocitosis de las células apoptóticas. Esta señalización se logra mediante el movimiento de la fosfatidilserina, la cual en condiciones normales está orientada hacia el interior de la bicapa lipídica, y en una célula apoptótica se ubica en la cara externa de la membrana plasmática (Bratton y col., 1997; Jayakiran, 2015).La fosfatidilserina es un ligando cotidiano para los fagocitos. La anexina $V$ es una proteína de unión a la fosfatidilserina e interactúa con ésta última de manera específica, por lo tanto se puede utilizar para detectar apoptosis (van Engeland y col., 1998; Arur y col., 2003).

\subsubsection{Vía extrínseca}

La vía de señalización extrínseca que inicia la apoptosis implica interacciones mediadas por receptores transmembrana o "receptores de la muerte" (Locksley y col., 2001; Kolb y col., 2017). Los miembros de esta familia comparten dominios extracelulares similares y 
un dominio citoplasmático de aproximadamente 80 aminoácidos llamado "dominio de muerte" (Ashkenazi y Dixit, 1998).

Los dominios de muerte juegan un papel crítico en la transmisión de la señal apoptótica desde la superficie celular a las vías de señalización intracelular. Hasta la fecha, los ligandos mejor caracterizados y sus receptores de muerte son FasL/FasR y TNF- $\alpha / T N F R$, Apo3L/DR3, Apo2L/DR4 y Apo2L/DR5 (Chicheportiche y col., 1997; Ashkenazi y Dixicai, 1998; Peter y Kramer, 1998; Suliman y col., 2001; Rubio-Moscardo y col., 2005).

La secuencia de eventos que caracterizan a la fase extrínseca de apoptosis se observa mejor con los modelos de FasL/FasR y TNF- $\alpha$ /TNFR1. En estos, tras la unión del ligando, ciertas proteínas citoplasmáticas adaptadoras, que exhiben dominios de muerte, son reclutadas y se unen con los receptores correspondientes.

La unión del ligando de Fas al receptor Fas, resulta en la unión de la proteína adaptadora FADD, y la unión de TNF a su receptor da como resultado la unión de la proteína adaptadora TRADD (Hsu y col., 1995; Grimm y col., 1996; Wajant, 2002). La proteína FADD, se asocia con la procaspasa-8 a través de la dimerización del dominio de la muerte. En este punto está formado el complejo de señalización de inducción de la muerte (DISC), lo que resulta en la activación autocatalítica de la procaspasa-8 (Kischkel y col., 1995). La caspasa-8 activa puede iniciar la fase ejecutora de la apoptosis. Esta vía de apoptosis mediada por el receptor de la muerte puede ser inhibida por una proteína llamada c-FLIP que tiene capacidad para unirse a FADD y a la caspasa-8, haciéndolos obsoletos (Kataoka y col., 1998; Scaffidi, 1999).

\subsubsection{Vía Intrínseca}


La vía intrínseca que inicia la apoptosis requiere la existencia de estímulos originados en la mitocondria que producen señales que actúan directamente sobre la célula (Kolb y col., 2017). Estas señales intracelulares pueden actuar en forma positiva o negativa. Las señales negativas consisten en la deficiencia de factores de crecimiento u hormonas que producen pérdida de la supresión de apoptosis, y por consiguiente, la activación de la misma. Como ejemplos de señales positivas se incluyen, (pero no se limitan a): radiaciones, toxinas, hipoxia, hipertermia, infecciones virales y radicales libres. Todos estos estímulos causan cambios a nivel de la membrana mitocondrial interna que se traduce en alteración de su permeabilidad, llevando a la pérdida del potencial transmembrana y a la liberación de dos grupos de proteínas pro-apoptóticas al citosol (que normalmente están secuestradas en el espacio intermembrana) (Saelens y col., 2004).

El primer grupo está compuesto por las proteínas pro-apoptóticas: citocromo c, Smac/DIABLO y HtrA2/Omi (Cai y col., 1998; Du y col., 2000; van Loo y col., 2002a; van Loo y col., 2002b; Garrido y col., 2006). El citocromo c se une a Apaf-1 formando una "apoptosoma" cuya finalidad es activar a la procaspasa-9 (Chinnaiyan, 1999; Hill y col., 2004), mientras que Smac/DIABLO y HtrA2/Omi promueven la apoptosis mediante la inhibición de la actividad de IAP (inhibidor de proteínas de apoptosis) (van Loo y col., 2002a; van Loo y col., 2002b; Schimmer, 2004; Jayakiran, 2015).

El segundo grupo de proteínas pro-apoptóticas incluye a: AIF, endonucleasa G y CAD. El AIF se transloca al núcleo y causa la condensación de la cromatina nuclear periférica (Joza y col., 2001), esta forma temprana de condensación nuclear se conoce como "etapa I" de condensación (Susin y col., 2000). La endonucleasa G también se transloca al núcleo 
donde escinde la cromatina nuclear para producir fragmentos de ADN oligonucleosomal (Li y col., 2001). Tanto AIF como la endonucleasa G funcionan de manera independiente de caspasas. CAD también se dirige al núcleo donde, después de ser separada de su inhibidor (ICAD) por la caspasa-3, lidera la fragmentación oligonucleosomal del ADN y una más pronunciada condensación de la cromatina (Enari y col., 1998), denominada "etapa II de condensación " (Susin y col., 2000).

El control y regulación de estos eventos apoptóticos mitocondriales se produce a través de miembros de la familia de proteínas $\mathrm{Bcl}-2$, los cuales regulan la permeabilidad mitocondrial y pueden ser pro o anti-apoptóticos (Cory y Adams, 2002). Los principales miembros anti-apoptóticos incluyen: $\mathrm{Bcl}-2, \mathrm{Bcl}-\mathrm{x}, \mathrm{Bcl}-\mathrm{XL}, \mathrm{Bcl}-\mathrm{XS}, \mathrm{Bcl}-\mathrm{w}$ y BAG; y los proapoptóticas más representativos son: Bax, Bak, Bid, Bad, Bim, Bik y Blk. Estas proteínas tienen un significado especial, ya que pueden determinar si la célula se compromete con la apoptosis o si aborta el proceso. Se cree que el principal mecanismo de acción de la familia de proteínas $\mathrm{Bcl}-2$ es la regulación de la liberación del citocromo c de la mitocondria a través de la alteración de la permeabilidad de la membrana mitocondrial. El daño mitocondrial originado tras la activación de la vía extrínseca Fas está mediada por la escisión de la pro-caspasa 8 por Bid (Li y col., 1998; Esposti, 2002). Este es un ejemplo de la interconexión entre la vía de muerte mediada por receptor (vía extrínseca) y la vía mitocondrial (vía intrínseca) (Igney y Krammer, 2002).

\subsubsection{Vía del retículo endoplasmático}

El RE es la organela celular en el que se sintetizan y modifican las proteínas de membrana y secretorias. El RE presenta 3 receptores transmembrana de estrés: PERK, ATF6 e IRE1, y 
sobre su cara citosólica aloja a la caspasa-12, la cual se sintetiza como una proenzima inactiva (Nakagawa y col., 2000). La caspasa-12 activada, escinde directamente la caspasa9, que a su vez activa la caspasa-3 (Morishima y col., 2002; Rao y col., 2002). En las células no estresadas, tanto las moléculas PERK, ATF6 e IRE1 como la caspasa-12 se mantienen en estado inactivo gracias a la unión de la proteína GRP78. La proteína GRP78 es la que impide la activación de estos factores (Groenendyk y col., 2005).

La acumulación de proteínas no plegadas en el lumen del RE induce una serie de respuestas adaptativas, que se denominan colectivamente "Unfolded Protein Response" (UPR) (Rutkowski y col., 2004). Esta situación es frecuentemente observada durante las infecciones virales, debido a la extensa producción proteica durante el ciclo replicativo. La UPR sería responsable de inactivar a GRP78 desencadenando de esta manera la apoptosis celular originada en el RE, teniendo a la caspasa-12 como principal protagonista.

\subsubsection{Vía ejecutora común}

Tanto la vía extrínseca como la intrínseca y la del retículo, terminan en un punto común denominado "fase de ejecución", considerada la ruta final de la apoptosis. Esta fase comienza con la activación de las caspasas efectoras $-3,-6$, y -7. Estas caspasas activan: endonucleasas citoplasmáticas, que degradan material nuclear, y proteasas, que degradan las proteínas nucleares y del citoesqueleto, manifestándose los cambios morfológicos observados en las células apoptóticas (Slee y col., 2001; Nagata, 2018).

La caspasa-3 es considerada la más importante de entre las "verdugo" y es activada por cualquiera de las caspasas iniciadoras (caspasa-8, -9, o -12). La caspasa-3 activa específicamente a la endonucleasa CAD. En las células normales, CAD forma un complejo 
con su inhibidor: ICAD. En las células apoptóticas, la caspasa-3 escinde ICAD para liberar CAD (Sakahira y col., 1998). CAD a continuación, se dirige al núcleo para degradar el ADN cromosómico y provocar la condensación de la cromatina.

La caspasa-3 también induce la reorganización del citoesqueleto y la posterior desintegración de la célula en cuerpos apoptóticos. La gelsolina ha sido identificada como uno de los principales blancos de la caspasa-3 activada. La caspasa-3 escindirá a la gelsolina y los fragmentos de esta, a su vez, escindirán los filamentos de actina. Esto resulta en alteraciones del citoesqueleto, del transporte intracelular, de la división celular y de la transducción de señales (Kothakota y col., 1997).

La eliminación de las células apoptóticas es el último paso de este proceso de muerte celular programada. La externalización de la fosfatidilserina en la superficie de las células y cuerpos apoptóticos es el "promotor" de esta última fase. La aparición de fosfotidilserina en el cara externa de las células apoptóticas facilita el reconocimiento y la fagocitosis no asociada a inflamación (Fadok y col., 2001; Kolb y col., 2017). Este proceso de captación temprana y eficiente, sin la liberación de los componentes citoplasmáticos, da como resultado ausencia de respuesta inflamatoria (Nagata, 2018).

\subsection{Modulación viral de la apoptosis}

Los vertebrados superiores han desarrollado dos mecanismos principales para controlar la infección viral, ambos dependen de la eliminación de las células infectadas por apoptosis.

- Uno se basa en la respuesta inmune: los péptidos virales son presentados en la superficie de la célula junto al $\mathrm{CMH}$, permitiendo de esta manera su 
reconocimiento por los LT citotóxicos (Oldstone, 1997), que a su vez envían una señal pro-apoptótica a la célula infectada.

- El otro mecanismo de defensa es endógeno de la célula parasitada: en este, la célula infectada detecta una activación "no programada" del ciclo celular inducido por las proteínas virales. La célula huésped puede distinguir el origen de la activación de este ciclo porque, cuando es activado naturalmente por factores de crecimiento, se producen dos tipos de señales: de proliferación celular y señales que suprimen la apoptosis (Harrington y col., 1994).

La replicación exitosa se basa en la capacidad de ciertos productos virales para bloquear o retrasar la apoptosis hasta que se haya producido suficiente progenie viral. Estas proteínas se dirigen a puntos estratégicos en las distintas vías de apoptosis. Varios productos virales pueden interactuar directamente con los componentes que regulan la muerte celular. Por un lado, los virus bloquearían la apoptosis para prevenir la muerte prematura de la célula huésped y así maximizar la progenie viral en la infección lítica y/o para facilitar una infección persistente. Por otro lado, parece que un número creciente de virus promueven activamente la apoptosis. Incluso un mismo virus puede desempeñar ambas funciones, al principio inhibe la apoptosis y luego promueve este proceso, siendo esta muerte celular la culminación de una infección lítica, facilitando la propagación de la progenie viral a las células vecinas mientras, a la vez que se evade la respuesta inflamatoria del huésped.

Es probable que las proteínas de virus ADN tumorales tales como el adenovirus E1A, el papilomavirus humano 16 (HPV-16) o del virus SV40 de los simios permitan la activación 
del ciclo celular pero no proporcionen las señales de supresión de la apoptosis. Mientras que los mecanismos fisiológicos y bioquímicos de estos procesos infecciosos aún faltan determinarse, la activación del ciclo celular provocada por las proteínas virales se reconoce como "no propia" y la célula es eliminada por apoptosis autoinducida (White, 1994; Eick y Hermeking, 1996). En muchos casos se ha demostrado que este suicidio celular está mediado por la proteína supresora de tumores p53 (Symonds y col., 1994; Lowe y Ruley, 1993). Además de proporcionar las proteínas que pueden estimular la proliferación celular en células huésped, los virus ADN tumorales han desarrollado varias estrategias para inactivar la función de la proteina p53, evitando la apoptosis accionada por esta. Diferentes virus emplean distintos mecanismos, dependientes e independientes de la inactivación de p53, para bloquear la apoptosis.

Dentro de los virus que muchos virus han encontrado una ventaja en la inducción de este mecanismo, se destacan los de genoma ARN, (Thomson, 2001; Maestre y col, 2011; StLouis y col, 2005; Lin y col., 2002; Archambault y St-Laurent, 2000; Sur y col., 1998; Koyama, 1995). Según Koyama y col. (2000), la ventaja para una partícula viral de inducir esta muerte celular luego de la infección celular sería que este proceso permitiría la rápida fagocitosis de las células infectadas por parte del sistema inmune innato, evitando así una respuesta inflamatoria en el sitio de la infección y retrasando la respuesta inmune específica hacia el virus. Con respecto a los constituyentes virales responsables de este fenómeno, y a la relación entre apoptosis y patogenicidad viral, hay discrepancias según el virus que se trate. Por ejemplo, en el virus rábico, se conoce que la proteína G de una cepa no-patogénica, es capaz de producir apoptosis, fenómeno que no ocurre en cepas 
altamente patogénicas (Prehaud y col., 2003). Por otro lado, otros estudios demuestran que solo determinados dominios de una proteína en particular son los responsables de la inducción de apoptosis por el virus de Newcastle (Ravindra y col., 2008; Ghrici y col., 2013).

\subsection{Arterivirus y apoptosis}

Dentro de la familia viral Arteriviridae, existe gran cantidad de bibliografía en base al VSRRP y su relación con el mecanismo de apoptosis (Karniychuk y col., 2011; Costers y col., 2008; Lee y Kleiboeker, 2007; Miller y Fox, 2004; Labarque y col., 2003; Sur y col., 1998). Para esta virosis porcina, la inducción del mecanismo de apoptosis ha sido relacionada con la patogenia, tanto in vitro como in vivo, observable luego de las infecciones virales (Sato y col., 2000).

Respecto al VAE se ha encontrado que infecciones de este virus inducen la muerte celular programada o apoptosis en cultivos celulares (Archambault y St-Laurent, 2000). Sin embargo, los estudios entre la inducción de la apoptosis y las infecciones con el VAE son escasos en la bibliografía científica. Uno de los primeros trabajos reportó fragmentación del ADN y activación de las caspasas tras la infección de células Vero con el VAE (Archambault y St-Laurent, 2000), siendo las caspasas -8 y -9 las enzimas involucradas en la activación de este mecanismo (St-Louis y Archambault, 2007). En 2013, un grupo de trabajo puso en evidencia la inducción de la vía intrínseca de apoptosis inducida por el VAE tras la infección de células BHK-21 (Cholleti y col., 2013).

Al igual que en el VSRRP, las proteínas M y gP5 del VAE forman un dímero constituyente de la envoltura viral que representa gran importancia en la infectividad de la partícula viral 
madura (Balasuriya y col., 2000; Snijder y col., 2003). Un trabajo reciente de nuestro grupo de investigación halló inducción del fenómeno de apoptosis tras la expresión de la proteína gP5 del VAE en células de insecto (Metz y col., 2014). La expresión de la proteína gP5 del VSRRP también ha sido asociada como un factor clave y desencadenante en la inducción de la apoptosis. En la investigación de Suarez y col. (1996), se demostró, utilizando construcciones recombinantes conteniendo el ORF5 del VSRRP, que la región ORF 5 es responsable de inducir apoptosis. Además, la apoptosis no sería inhibida por la proteína anti-apoptótica Bcl-2, ya que el estudio se llevó a cabo en células neurales que expresaban $\mathrm{Bcl}-2$ en forma constitutiva.

Posteriormente, se identificó la región de la proteína gP5 responsable de la inducción de la apoptosis, la cual está comprendida entre N119 y C90 (Fernández y col., 2002). Un año después se observó la activación de la procaspasa -3 y la positividad frente a la técnica de TUNEL (utilizada para determinar apoptosis) en células 293 infectadas con Adenovirus-gP5 del VSRRP (Gagnon y col., 2003).

Sin embargo, en el trabajo de Miller y colaboradores de 2004, donde se relacionó la apoptosis con la infección del VSRRP fueron analizados mediante técnica de microarray 26 genes apoptóticos, no observándose diferencias significativas con los cultivos sin infectar. En este mismo trabajo se planteó la posibilidad de que la apoptosis celular estaría muy relacionada con factores solubles del medio de cultivo cuando este está en contacto con las células por tiempo prolongado ("spent medium"). En este trabajo también se analizó por TUNEL la presencia de células apoptóticas y por IFD la presencia de antígeno (Ag) viral, determinándose que el número de células que eran positivas simultáneamente a ambas 
técnicas fue extremadamente bajo. En la discusión de este trabajo, los autores plantearon la hipótesis de que el VSRRP produciría "apoptosis bystandard", debido a que las células blanco del virus, los macrófagos, liberan TNF $\alpha, y$ este último sería el responsable de inducir apoptosis en las células vecinas. Por último, estos autores analizaron la inducción de dos proteínas antiapoptóticas, ATF3 y Hsp70, que fue positiva tras la infección por el VSRRP.

Otra investigación donde se trató de demostrar la malinterpretación de los resultados del estudio de Suarez, fue la llevada a cabo por Lee y colaboradores en 2004. En este trabajo se logró expresar en forma transiente la proteína gP5 del VSRRP en células HeLa. Posteriormente se extrajo el ARNm a distinto tiempo para analizar por microarrays la activación de distintos genes relacionados con la apoptosis celular. Los resultados demostraron una diferencia nula con respecto a las células transfectadas con el vector vacío, desacreditando la hipótesis de inducción de la apoptosis por la proteína gP5 del VSRRP.

Por otro lado, Gao y colaboradores en 2014 crearon una línea celular derivada de MARC145 que expresaba en forma estable la proteína gP5 del VSRRP. Lo que observaron fue que estas células eran refractarias a la infección por el VSRRP, por inducirse la actividad del IFN $\beta$. La infección fue posible una vez bloqueada la acción del IFN $\beta$, utilizando un ARN silente (ARNs). Por lo tanto, si bien no observaron inducción de apoptosis ni cambio alguno en la proliferación celular en estas células estables que contenían de manera constitutiva la gP5, si pudieron demostrar una relación directa entre la expresión de esta proteína viral y la permisibilidad de infección por el VSRRP. 
Gao y colaboradores demostraron (2014), que la expresión de gP5 en las células MARC145 inhibe la replicación del VSRRP debido al aumento de IFN $\beta$, e incluso causa detención del ciclo celular en G2/M, pero no induce apoptosis. Estos investigadores realizaron mediciones citométricas de células marcadas con Anexina/loduro de propidio, detección de caspasa -3 y Ladder de ADN y no observaron resultados consistentes con apoptosis. Luego de varios años de versiones contradictorias al respecto del efecto pro- o antiapoptótico del VSRRP, los últimos estudios arrojan resultados que podrían validar todos los anteriores. Se observó que durante las etapas tempranas de la infección viral por VSRRP, se inhibe la apoptosis (Wang y col, 2016) y que ésta es estimulada en la etapas tardías, a distintos tiempos según la línea celular (12 hs en PAM y 24 hs en MARC-145) (Yuan y col. 2016).

Con respecto al VAE, no existen datos que relacionen patogenicidad viral con el efecto apoptótico observado, y son escasos los estudios donde se relaciona a la proteína gP5 con este fenómeno, no habiéndose considerado como responsable de estimular o inhibir este proceso alguna otra proteína viral. 


\subsection{Esquema de vías apoptóticas}

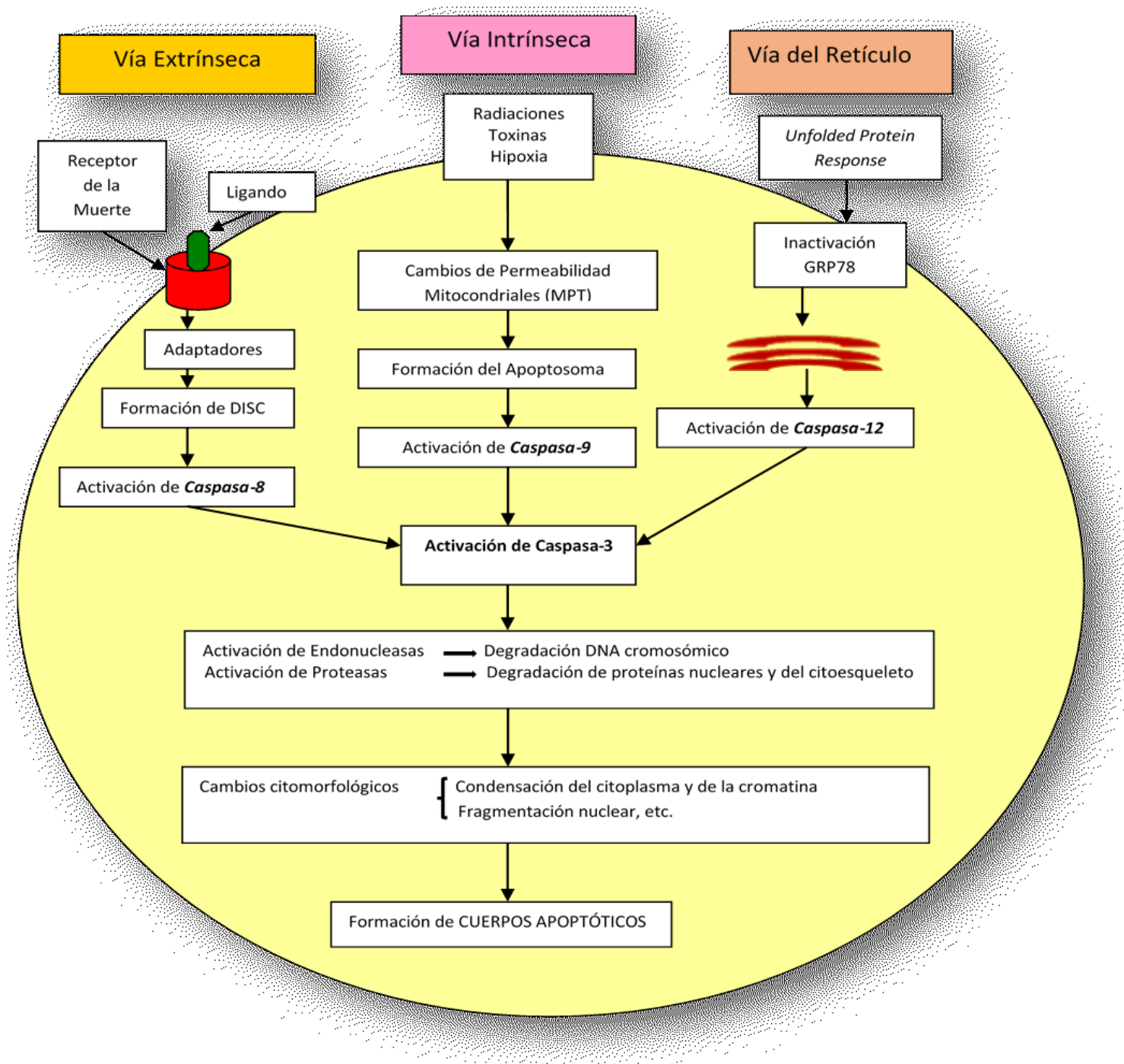

Figura 3: Esquema de las vías apoptóticas. Se observa las causas de la activación de las vías extrínseca (caspasa-8), intrínseca (caspasa-9) y del retículo endoplasmático (caspasa-12). La formación de los cuerpos apoptóticos es la consecuencia final de la activación de la vía ejecutora común, representada por la caspasa-3. 


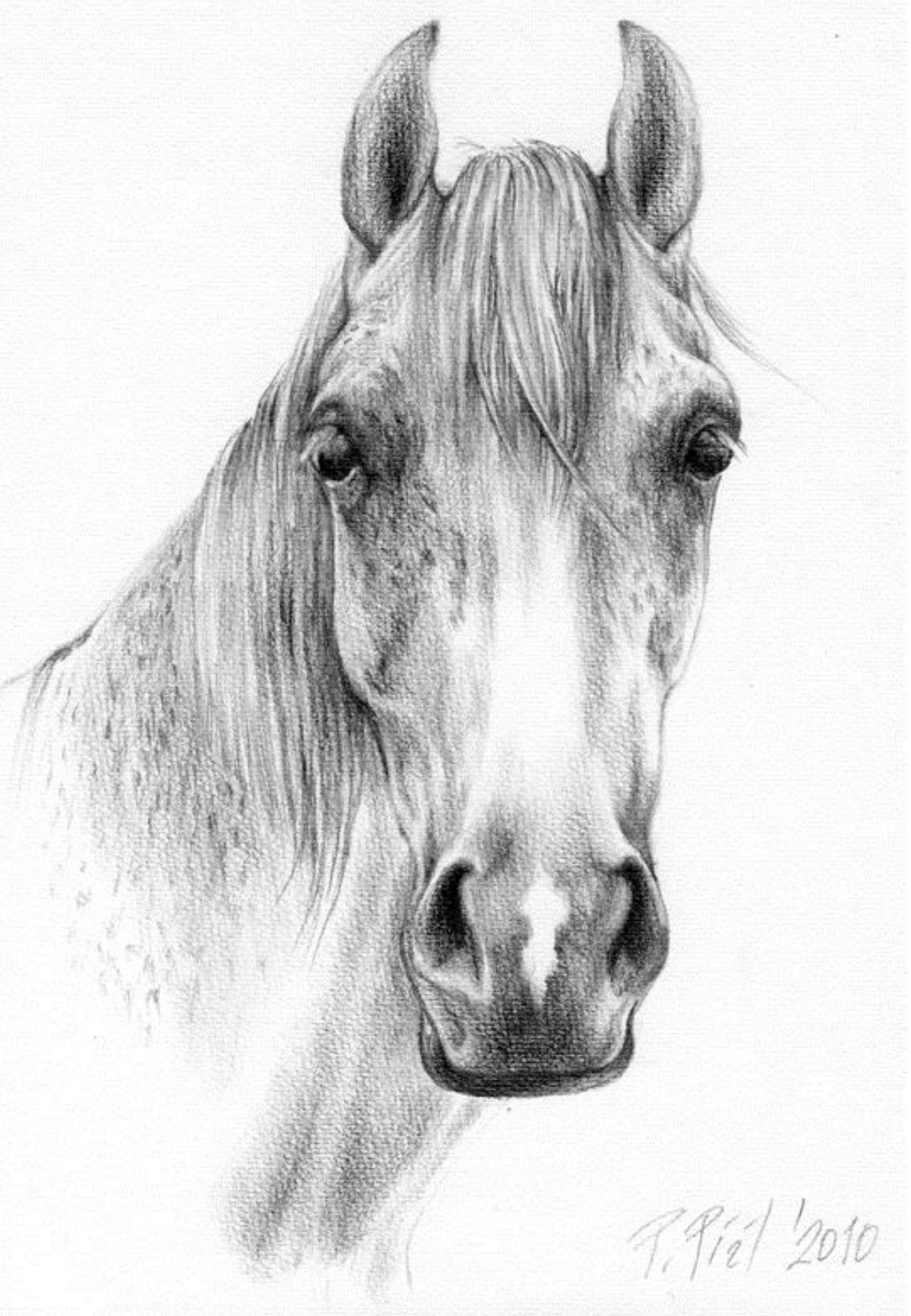

\section{Hipótesis y objetivos}




\section{Hipótesis}

Teniendo en cuenta que se desconoce de qué manera interactúa el VAE con el mecanismo de respuesta apoptótica de las células infectadas, se plantean las siguientes hipótesis:

1) El grado de inducción de apoptosis por VAE en cultivos celulares está relacionado con el origen filogenético y la patogenicidad viral de las cepas empleadas.

2) La expresión de las proteínas N, M y GP5 son responsables de la inducción de apoptosis en el sistema de cultivos celulares empleados en la experiencia.

\section{Objetivos generales y específicos}

El objetivo general de este plan de trabajo es estudiar la inducción de la apoptosis en cultivos celulares tras la infección con el VAE. Se estudiarán diferentes mecanismos moleculares implicados en este proceso mediante el empleo de distintas cepas del VAE a través de la expresión diferencial de proteínas virales en cultivos.

El avance en este tema permitirá profundizar los conocimientos para esta virosis con el propósito general de correlacionar este fenómeno de apoptosis con la patogenicidad ocasionada por las distintas cepas del VAE.

Los objetivos específicos son los siguientes:

- Seleccionar cepas del VAE en base a diferencias filogenéticas y de patogenicidad para analizar sus efectos en los mecanismos de inducción apoptótica.

- Clonar y expresar proteínas del VAE (proteínas M, gP5 y N) en sistema eucariota.

- Analizar mediante métodos que determinen cambios morfológicos y bioquímicos el efecto de las proteínas clonadas de las cepas seleccionadas con la apoptosis celular. 


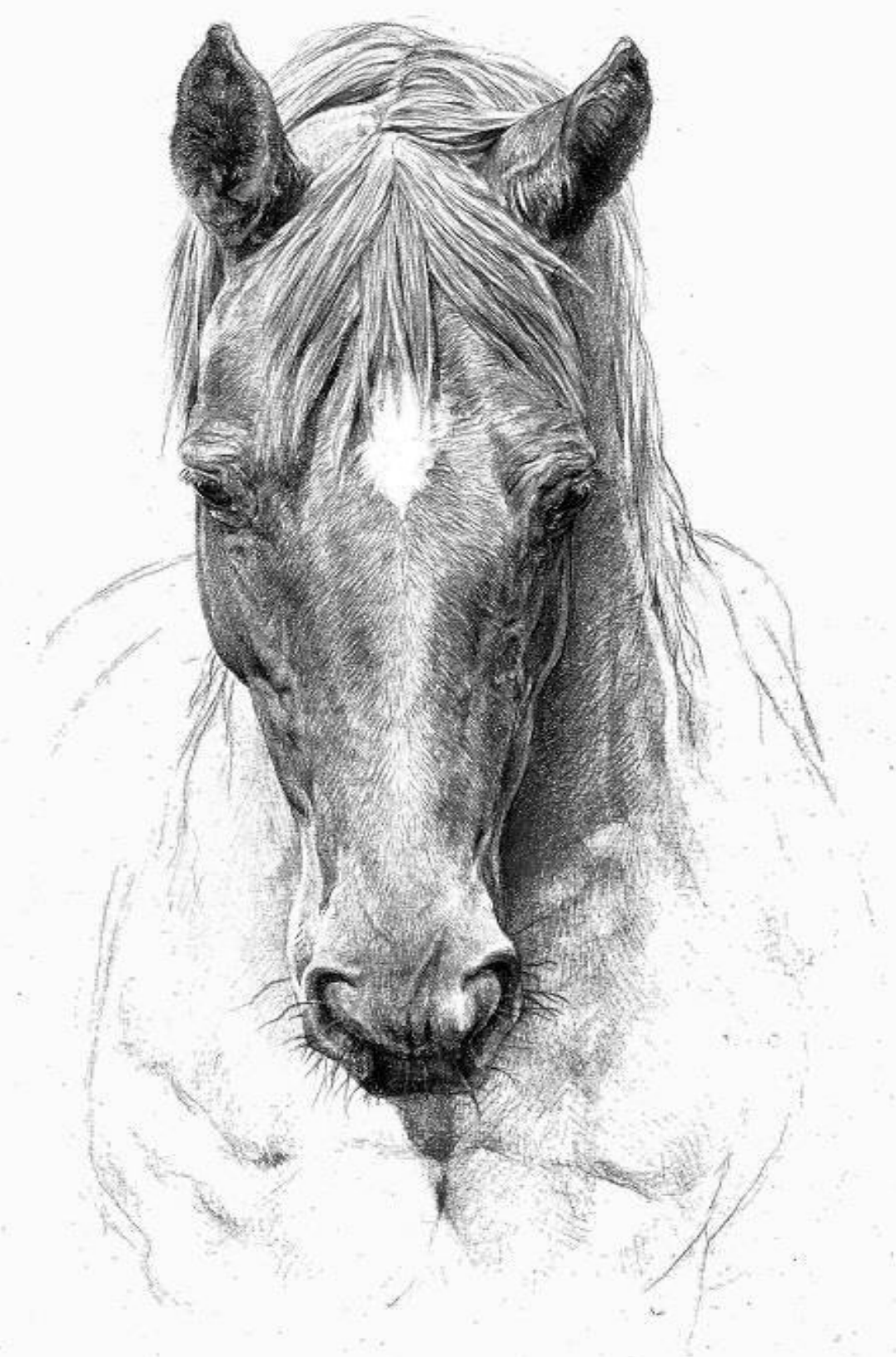

Gyiuker Zódea 2014

\section{Materiales y métodos}


A. Medios y soluciones de cultivo

B. Células

C. Virus

D. Vectores utilizados

1 Extracción del ARN viral

2 Obtención de los ADNc

3 Diseño de cebadores para PCR

4 Reacción de PCR

5 Purificación y cuantificación de los productos de PCR

6 Subclonado de los genes en pGEM T-easy

7 Extracción de ADN plasmídico

8 Digestión enzimática de los vectores de clonado

9 Purificación y cuantificación de los productos digeridos

10 Ligación de los genes de interés al vector de expresión pCDNA 3.1(+)

11 Transfección con Lipofectamina 2000

12 Análisis de la expresión en geles de poliacrilamida

13 Análisis de la expresión por Western blot

14 Análisis de la transcripción de los ARNs mensajeros de los genes clonados

15 Detección de apoptosis por fragmentación del ADN

16 Detección de apoptosis por tinción diferencial (NA/BE)

17 Detección de apoptosis por citometría de flujo

18 Detección de caspasas-3,-8 y-9 in situ por inmunotinción 


\section{A. Medios y soluciones de cultivo}

Como medio de crecimiento celular (MC) se utilizó MEM Eagle con el agregado de 0,3 $\mathrm{mg} / \mathrm{ml}$ de glutamina, $200 \mathrm{UI} / \mathrm{ml}$ de penicilina, $0,5 \mathrm{mg} / \mathrm{ml}$ de estreptomicina, $20 \mathrm{UI} / \mathrm{ml}$ de nistatina y $10 \%$ de suero fetal bovino (SFB). El pH final del medio fue de 7,2 logrado con la adición de bicarbonato de sodio al 7,5\%. Para el medio de mantenimiento, se redujo el suero al 2\% (MM). Para la disgregación de las monocapas celulares se utilizó una solución de tripsina (Laboratorios Difco, USA) al $0,25 \%$ y sal sódica del ácido etilendiaminotetracético (EDTA) al 0,2\% en solución tamponada de fosfatos (PBS).

\section{B. Células}

Para todas las experiencias los sustratos utilizados fueron células de las líneas comerciales: RK-13 (Rabbit Kidney), Vero-E6 (African Green Monkey Kidney) y BHK-21 (Baby Hamster Kidney) (ABAC, Asociación de Bancos Celulares de la Argentina), las que fueron cultivadas en monocapas en placas de 6 o 12 pocillos, en placas de Petri de 3,5 cm de diámetro o en frascos de cultivo de $25 \mathrm{~cm}^{2}$, según correspondiera.

\section{Virus}

Se utilizaron tres cepas virales de distinta patogenicidad y origen filogenético:

- Una cepa vacunal derivada de la cepa Bucyrus del VAE cedida por el Dr. W. McCollum de la Universidad de Lexignton, Kentucky, USA, como cepa de referencia mundial (Balasuriya 1995a y 1995b), de origen americano y de alta patogenicidad.

- La cepa LP-01 aislada en nuestro laboratorio en el 2002 (Echeverría, 2007), de origen europeo y de baja patogenicidad. 
- Por último, como cepa europea y de alta patogenicidad, se utilizó la cepa GLD-LPARG aislada en nuestro laboratorio en el 2010, responsable del primer brote de AVE en nuestro país (Metz, 2014).

\section{Vectores utilizados}

En este trabajo fueron utilizados dos vectores: PGEM T-easy como paso intermedio en el proceso de clonado de los genes de interés en el vector de expresión y pCDNA3.1(+) para la sobreexpresión de los genes en células animales. Sus características principales son:

\section{- pGEM T-easy}

pGEM-T easy es un vector de alto número de copias que contiene los promotores T7 y SP6 para ARN polimerasa, los que rodean un sitio de multiclonado, el cual a su vez interrumpe la secuencia que codifica para la región alfa de la enzima $\beta$-galactosidasa (Figura 4).

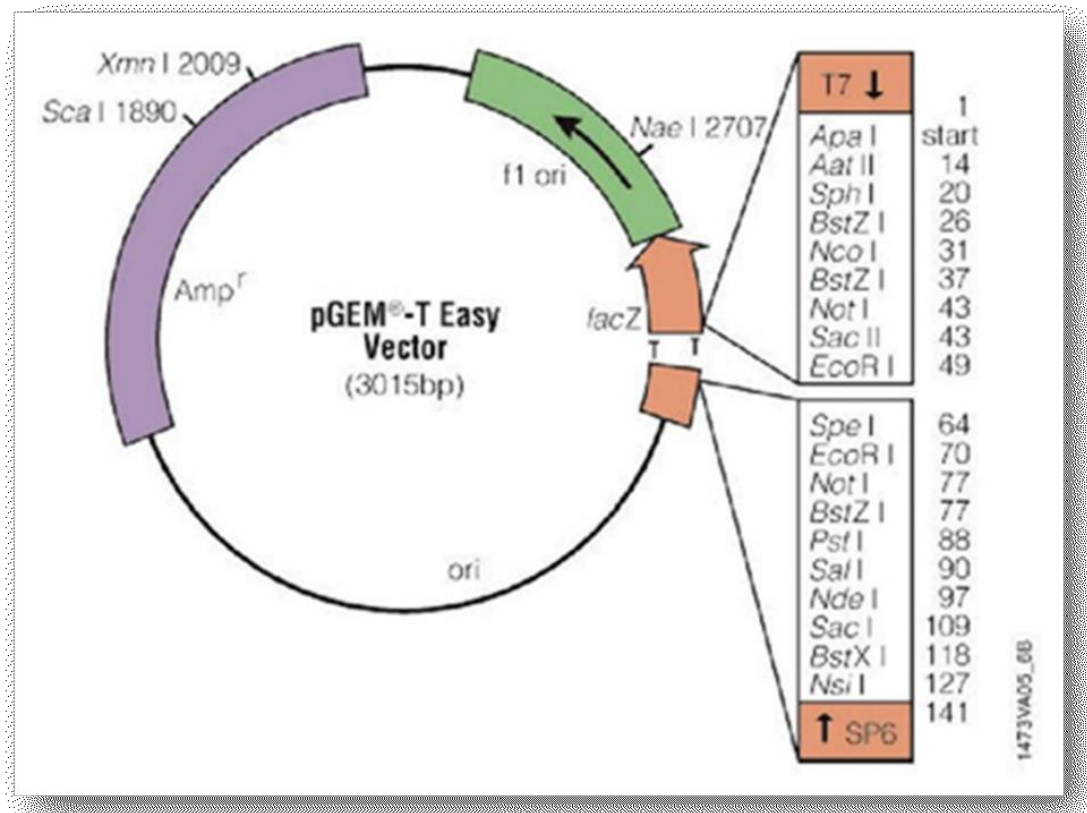

Figura 4: Esquema del vector de clonado pGEM T-easy. Se observa el sitio de multiclonado, el cual interrumpe la secuencia que codifica para la región alfa de la enzima $\beta$-galactosidasa. Este vector presenta resistencia a ampicilina para su clonado y selección en $E$. coli. 
La Taq polimerasa es capaz de agregar adeninas adicionales en los extremos de los fragmentos replicados en una reacción de PCR. La presencia de timinas en el sitio de clonado de este vector, permite la ligación del producto de interés, de forma de interrumpir la secuencia de la $\beta$-galactosidasa. Así, los clones que hayan integrado el vector vacío serán capaces de degradar $X$-gal, un análogo de galactosa que, al ser utilizado como sustrato por esta enzima tiene como producto 5-bromo-4-cloro-3-hidroxindol, el cual es oxidado para formar un compuesto azul insoluble, con lo que estas colonias pueden ser distinguidas a simple vista en una placa de agar con $X$-gal. Adicionalmente, este vector presenta resistencia a ampicilina para su clonado y selección en $E$. coli.

- pcDNA 3.1(+)

El vector pcDNA 3.1(+) es un vector derivado de pcDNA 3, diseñado para la sobreexpresión estable y transiente en células animales. Posee un tamaño de 5,4 Kb, el promotor de citomegalovirus humano (CMV) y del papovavirus SV40 (SV40); presenta resistencia a ampicilina para selección en $E$. coli; y a geneticina para selección en células animales. Adicionalmente el vector posee un sitio de multiclonado el que se representa en la Figura 5. 


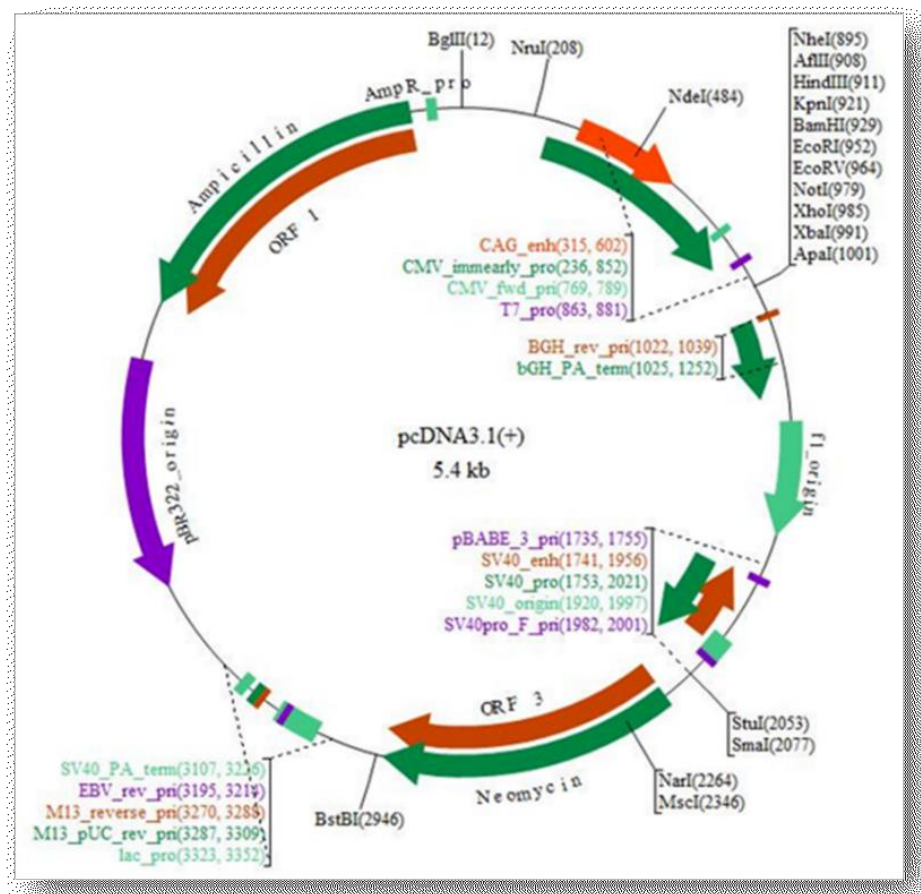

Figura 5: Esquema del vector de expresión pcDNA 3.1(+). Se observa el sitio de multiclonado y los promotores CMV y SV40. Este vector presenta resistencia a ampicilina para selección en E. coli; y a geneticina para selección en células animales.

\section{Extracción del ARN viral}

Para la obtención de los distintos ARN virales de VAE se infectaron monocapas de células RK-13 con inóculos de cada una de las cepas virales anteriormente nombradas. Las células fueron incubadas por 60 min a 37으 y se completó luego con MM. Las células fueron evaluadas diariamente hasta observar el ECP característico de la infección: la lisis celular. La extracción del ARN viral se realizó por el método de extracción fenólica con Trizol (Invitrogen). Se mezclaron $500 \mu$ de sobrenadante de células infectadas con $500 \mu$ de Trizol y $220 \mu \mathrm{l}$ de cloroformo. Se vortereó violentamente por $10 \mathrm{~min}$, se centrifugó a $12000 \mathrm{rpm}$ a 4ํC durante $10 \mathrm{~min}$ y se trasvasó la fase acuosa (aproximadamente $650 \mu \mathrm{l}$ ) a un tubo de microcentrífuga nuevo. EI ARN se precipitó a $-70^{\circ} \mathrm{C}$ toda la noche con el agregado de $750 \mu \mathrm{l}$ de isopropanol. Al día siguiente, se centrifugó a $12000 \mathrm{rpm}$ a 4으 
durante 10 min, se descartó el sobrenadante y se lavó el precipitado con $500 \mu$ le alcohol 70․ Se centrifugó a $7500 \mathrm{rpm}$ por $5 \mathrm{~min}$ y se descartó el alcohol. El pellet se desecó aproximadamente 10 min a $37^{\circ} \mathrm{C}$ y se resuspendió el ARN viral en $40 \mu$ l de agua libre de nucleasas.

\section{Obtención de los ADNc}

Los ADNc se sintetizaron a partir del ARN total obtenido en el punto anterior mediante transcripción reversa utilizando hexámeros al azar como cebadores y transcriptasa reversa del virus de la leucemia murina de Maloney (MMLV).

La técnica de PCR Retrotranscriptasa (RT-PCR) se realizó en dos fases. En la primera de ellas se mezclaron $5 \mu \mathrm{l}$ del ARN con $1 \mu \mathrm{l}$ de hexámeros al azar y $9 \mu \mathrm{l}$ de agua libre de nucleasas. Las muestras fueron incubadas en bloque térmico a 70 으 durante 5 min para permitir la hibridización de los hexámeros. En una segunda fase se agregó al tubo de reacción: $1 \mu \mathrm{l}$ de MMLV, $5 \mu \mathrm{l}$ del buffer de la enzima MMLV, $1 \mu$ ld inhibidor de la ARNasa, $1 \mu \mathrm{l}$ de nucleotidostrifosfatos (dNTP`s) y $2 \mu \mathrm{l}$ de agua libre de nucleasas. Se

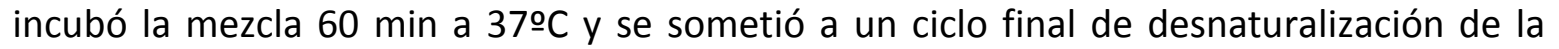
enzima a $94{ }^{\circ} \mathrm{C}$ por $5 \mathrm{~min}$ en termociclador Eppendorf Mastercycler Gradient. El ADNc obtenido se almacenó a -20ㅡC hasta su empleo.

\section{Diseño de cebadores para PCR}

Para llevar a cabo cada uno de los ensayos de PCR se diseñaron pares de cebadores específicos para los genes que codifican las proteínas N, M y gP5 (gen N, gen M y gen gP5). 
Se realizó un diseño preliminar utilizando el programa informático DNAman (Lynnon BioSoft 1994-1999). Dado que al momento del comienzo del trabajo se contaba con la secuenciación parcial de los aislamientos LP01 y GLD-LP-ARG, los diseños de los cebadores se basaron en la secuencia de la cepa de referencia de VAE publicada en el National Center of Biotechnology Information con el número de acceso: NC 002532.

Los parámetros de diseño de cada uno de los cebadores fueron los siguientes:

- Longitud entre 18 y 24 pares de base (pb) (sin contemplar los sitios de corte).

- Contenido de $\mathrm{G}+\mathrm{C} \geq 60 \%$.

- Temperatura de hibridación $\geq 54^{\circ} \mathrm{C}$.

- Alta compatibilidad entre el par de cebadores.

De todos los resultados obtenidos con el programa DNAman, se escogió el par de cebadores que permitiera obtener cada uno de los genes de interés. A cada par de cebadores seleccionado se le adicionó la secuencia de reconocimiento para una enzima de restricción acorde a la construcción a realizar. Se emplearon en todos los casos enzimas de restricción diferentes en cada uno de los cebadores del par. Para clonar los genes de las proteínas gP5, las enzimas de restricción seleccionadas fueron HindIII y BamHI, mientras que para los correspondientes a $\mathrm{M}$ y N se escogieron BamHI y Xhol.

El resultado final del diseño de los cebadores fue el siguiente: 
Primers para las construcciones pGEM T-easy-gP5

APO5F HindIII $5^{\circ}$-GGAAGCTTTGGGCTCAACGATGTTAT-3'

APO5R BamHI 5 -GGGGATCCATGAATCTATGGCTCCCA-3'

Primers para las construcciones pGEM T-easy-M

APOMF BamHI $5^{\circ}$-AAGGATCCAGGTATGGGAGCCATAGATT-3’

APOMR Xhol 5 '-TTCTCGAGCAGTAGGTCATTGTAGCTTGTA-3'

Primers para las construcciones pGEM T-easy-N

APONF BamHI $5^{\circ}$-GGGGATCCAGCTTGACGATGGCGTCAA-3*

APONR Xhol 5'-TTCTCGAGAATATCCACGTCTTACGGCCC-3’

\section{Reacción de PCR}

Las reacciones de PCR para amplificar cada uno de los genes de interés, se llevaron a cabo en un volumen final de $25 \mu$ utilizando los siguientes reactivos:

- PCR Master Mix 2X (Promega) conteniendo: $50 \mathrm{U} / \mathrm{ml}$ de Taq DNA Polimerasa en buffer adecuado a pH 8,5; $400 \mu \mathrm{M}$ dATP, $400 \mu \mathrm{M}$ dGTP, $400 \mu \mathrm{M}$ dCTP, $400 \mu \mathrm{M}$ dTTP; 3 mM MgCl 2 .

- Cebadores específicos con concentración de uso de $10 \mu \mathrm{M}$.

- La cantidad de ADNc molde varió entre 1-2 $\mu$ l (>250 ng).

Los volúmenes y concentraciones finales de los reactivos usados se indican en la siguiente tabla: 


\begin{tabular}{|ccc|}
\hline Componente & Volumen & Concentración final \\
\hline PCR Master Mix 2X & $12,5 \mu \mathrm{l}$ & $1 \mathrm{X}$ \\
Cebador derecho $10 \mu \mathrm{M}$ & $0,5 \mu \mathrm{l}$ & $0,2 \mu \mathrm{M}$ \\
Cebador reverso $10 \mu \mathrm{M}$ & $0,5 \mu \mathrm{l}$ & $0,2 \mu \mathrm{M}$ \\
ADNc molde & $1-2 \mu \mathrm{l}$ & $>250 \mathrm{ng}$ \\
Agua libre de nucleasas & $\operatorname{csp} 25 \mu \mathrm{l}$ & - \\
\hline
\end{tabular}

Tabla 2: Reactivos utilizados en las reacciones de PCR. Se enumeran los volúmenes y la concentración final de cada uno de los componentes utilizados.

Las reacciones de PCR se realizaron en equipo Eppendorf Mastercycler Gradient. Se confeccionaron cada uno de los ciclos de PCR acorde al par de cebadores utilizados, repitiendo cada uno de ellos entre 25 a 35 veces por programa.

Los ciclos utilizados fueron los siguientes:

\begin{tabular}{|c|c|c|c|}
\hline \multicolumn{2}{|c|}{ Programa $-\mathrm{M} / \mathrm{N}$} & \multicolumn{2}{|c|}{ Programa -gP5 } \\
\hline \multicolumn{2}{|c|}{ Desnaturalización 94드 - 55 seg } & \multicolumn{2}{|c|}{ Desnaturalización 94으 - $55 \mathrm{seg}$} \\
\hline Hibridización & $58 \circ \mathrm{c}-45 \mathrm{seg}$ & Hibridización & $56 \div$ C- 45 seg \\
\hline Extensión & $72^{\circ} \mathrm{C}-1 \mathrm{~min}$ & Extensión & $72^{\circ} \mathrm{C}-1 \mathrm{~min}$ \\
\hline Producto resu & nte: $511 \mathrm{pb} \quad$ (M) & \multirow{2}{*}{\multicolumn{2}{|c|}{ Producto resultante: 799 pb }} \\
\hline & $380 \mathrm{pb} \quad(\mathrm{N})$ & & \\
\hline
\end{tabular}

Tabla 3: Protocolos utilizados en las reacciones de PCR. Se observan las temperaturas de desnaturalización, hibridación y extensión de los ciclos de PCR utilizados para lo obtención de los genes M, N y gP5 del VAE. Se incluyen en la tabla los tamaños de los fragmentos esperados.

En algunos casos, los programas de ciclado fueron modificados a fin de obtener una mayor amplificación del gen de interés. Todos los programas poseían un ciclo inicial de desnaturalización $\left(95^{\circ} \mathrm{C}-3 \mathrm{~min}\right)$ y otro final de extensión $\left(72^{\circ} \mathrm{C}-5 \mathrm{~min}\right)$. 
Las reacciones de PCR se visualizaron en geles de agarosa en distintos porcentajes (entre 1 y $2 \%$ ), de acuerdo al tamaño del fragmento, utilizando TBE 1X (Tris Base 89 mM , Ácido Bórico 89 mM y 2 mM EDTA) como buffer de corrida. Como marcador de pares de bases se empleó generalmente el 100bp DNA Ladder (Promega). Los geles se sometieron a un voltaje de $100 \mathrm{~V}$ por un período de tiempo acorde al fragmento amplificado y utilizando para ello el frente de corrida presente en el buffer de carga. Los geles se tiñeron con Bromuro de Etidio $(0,5 \mu \mathrm{g} / \mathrm{ml})$ luego de la corrida y se visualizó el resultado bajo transiluminador de luz UV.

\section{Purificación y cuantificación de los productos de PCR}

La purificación de los fragmentos amplificados por PCR se realizó empleando el kit comercial Wizard SV Gel and PCR Clean-Up System (Promega), siguiendo el protocolo allí suministrado.

También se utilizó el método de purificación por precipitación por polietilenglicol (PEG). Para ello se agregó igual volumen de solución de $20 \%$ PEG - 2,5M NaCl a la mezcla de reacción de PCR. Se mezcló por inversión e incubó a 37ํㅡ por 15 min y luego se centrifugó a 15000 rpm durante 15 min a temperatura ambiente. Se descartó el sobrenadante, se lavó el pellet con $125 \mu$ de etanol $70 \%$ y se desecó a 37으 por 15-30 min. Finalmente el pellet se resuspendió en $10 \mu \mathrm{l}$.

Los productos así purificados fueron cuantificados en geles de agarosa empleando el MassRulerTM DNA Ladder, low range, ready-to-use (Fermentas) como patrón de referencia. Cada una de las bandas de este marcador posee una cantidad de ADN 
cuantificada y tabulada, por lo que la cuantificación de los productos de interés fue realizada en base a la comparación de intensidad de la banda incógnita con las bandas presentes en el marcador.

\section{Subclonado de los genes en pGEM T-easy}

Los productos de PCR fueron subclonados al vector de clonado pGEM-T Easy Vector Systems (Promega) siguiendo el manual de procedimiento del fabricante.

Para el clonado se utilizó una proporción molar de 3:1 de inserto: vector. Teniendo en cuenta un tamaño de $3 \mathrm{~kb}$ y una concentración provista por el fabricante de $50 \mathrm{ng} / \mathrm{ml}$ del vector pGEM-T Easy, se empleó la siguiente fórmula para el cálculo de la masa de inserto a utilizar:

[(ng vector $\mathrm{x} \mathrm{Kb}$ inserto) $\div \mathrm{Kb}$ vector $] \times$ proporción molar (inserto $\div$ vector)=ng inserto Una vez determinada la cantidad de inserto a utilizar para cada una de las ligaciones se procedió a la preparación de la siguiente mezcla de ligación:

- $5 \mu$ l Buffer 2X Ligación Rápida de la T4 ADN Ligasa.

- $1 \mu$ vector pGEM-T Easy (50ng).

- " $\mathrm{X}$ " $\mu \mathrm{l}$ producto de PCR.

- $\quad 1 \mu \mathrm{l}$ T4 ADN Ligasa $(3 U / \mu l)$.

- Agua libre de nucleasas: CSP $10 \mu \mathrm{l}$.

La reacción se mezcló por pipeteo e incubó 1 hora (h) a temperatura ambiente y/o toda la noche a $4^{\circ} \mathrm{C}$ de acuerdo a las recomendaciones del fabricante. 
Previo a la transformación, la ligación del producto de PCR al vector de clonado rápido se corroboró con el siguiente par de cebadores:

pUC/M13 Forward 5'-GTAAAACGACGGCCAGT-3' (2959-2975)

pUC/M13 Reverse 5'-CAGGAAACAGCTATGAC-3'(176-192)

La obtención de un producto de 251 pb indica la presencia de vector no ligado, mientras que 251 pb más el tamaño del inserto, indica la correcta ligación del inserto al vector. Una vez corroborada la ligación del gen de interés al vector de clonado pGEM-T Easy, se procedió a la competencia y transformación de las bacterias E. coli JM109.

Para la competencia de las bacterias se plaquearon las mismas por el método de estría por agotamiento utilizando placas LB. Una colonia aislada se picó y cultivó toda la noche en medio LB. A partir de este cultivo se realizó una dilución $1 / 100$ y se incubó a $37^{\circ} \mathrm{C}$ hasta obtener la fase log de crecimiento $(D O=0,6)$. En ese momento se centrifugó el cultivo a $3000 \mathrm{rpm}$ por 5 minutos a $4^{\circ} \mathrm{C}$ y se descartó el sobrenadante. Se agregaron $2 \mathrm{ml} \mathrm{de} \mathrm{MgCl}_{2}$ 100 mM y se centrifugó en las mismas condiciones. Se descartó el sobrenadante y se agregó $1 \mathrm{ml}$ de $\mathrm{MgCl}_{2} 100 \mathrm{mM}$ incubando $15 \mathrm{~min}$ en hielo. La mezcla se centrifugó, se descartó el sobrenadante y se agregó $1 \mathrm{ml}$ de $\mathrm{CaCl}_{2} 100$ mM. Se incubaron las células 15 min en hielo y nuevamente se centrifugó descartando el sobrenadante. Se resuspendieron las células en una solución mixta de $1 \mathrm{ml}$ de $\mathrm{MgCl}_{2} 100 \mathrm{mM}$ y $1 \mathrm{ml}$ de $\mathrm{CaCl}_{2} 100 \mathrm{mM}$ y se incubaron 15 min en hielo. Luego de esta incubación, las bacterias se consideran competentes.

La transformación se realizó con 2 o más $\mu$ l de la mezcla de ligación, de acuerdo al porcentaje de ligación observado. Se incubaron las células 20 min en hielo, 45 seg a $42^{\circ} \mathrm{C}$ y 
finalmente 5 min en hielo. Luego se agregaron $900 \mu$ de medio SOC y se incubó el tubo entre 1 a 2 hs a $37^{\circ} \mathrm{C}$ con agitación (150 rpm). Finalizada la incubación, se sembraron 100 $\mu \mathrm{l}$ de cada transformación, y el pellet resuspendido en el menor volumen posible, en placas de agar Luria Bertani (LB) (Triptona 10g/l; Extracto de levadura 5 g/l; NaCl 5g/l, Agar 15g/l) con el agregado de $100 \mu \mathrm{g} / \mathrm{ml}$ de Ampicilina, 80 $\mathrm{g} / \mathrm{ml}$ al 0,5mM isopropil- $\beta$-Dtiogalactopiranosido (IPTG) y $20 \mu \mathrm{g} / \mathrm{ml} \mathrm{X-Gal.} \mathrm{Las} \mathrm{placas} \mathrm{se} \mathrm{incubaron} 24$ hs a $37^{\circ} \mathrm{C}$ y de allí se seleccionaron las colonias blancas. Las mismas fueron analizadas por PCR con los cebadores específicos del vector (pUCM13). Los clones positivos se almacenaron en glicerol "stock".

\section{Extracción de ADN plasmídico}

La miniprep es la extracción de ADN de naturaleza plasmídica de un cultivo bacteriano. Para ello, a partir de una colonia aislada se hizo crecer un cultivo líquido en medio LB con $100 \mu \mathrm{g} / \mathrm{ml}$ de Ampicilina en agitación durante toda la noche a $37^{\circ} \mathrm{C}$. El cultivo se centrifugó a $15000 \mathrm{rpm}$ durante $5 \mathrm{~min}$. El sobrenadante se descartó y el precipitado bacteriano fue resuspendido en $100 \mu \mathrm{l}$ de solución P1, agitando vigorosamente en vórtex. Se agregaron $200 \mu \mathrm{l}$ de solución P2, se mezcló por inversión y luego de un reposo en hielo de 5 min se adicionaron $150 \mu \mathrm{l}$ de solución P3 fría. Se mezcló por inversión y se dejó en hielo por 5 min. Se centrifugó a $15000 \mathrm{rpm}$ a 4 으 durante 12 min y el sobrenadante obtenido fue transferido a un tubo de microcentrífuga limpio. Se adicionaron $1 \frac{1}{2}$ volúmenes de isopropanol frío y se centrifugó a $15000 \mathrm{rpm}$ durante $15 \mathrm{~min}$ a 4ํC. Se retiró el sobrenadante y se lavó el precipitado con un volumen igual de etanol 70\%, se centrifugó 
por 5 min y se descartó el sobrenadante. Se desecó y por último se resuspendió el ADN plasmídico en 20-30 $\mu \mathrm{l}$ de agua estéril libre de nucleasas (Promega).

Las soluciones empleadas en esta técnica fueron las siguientes:

- Solución P1: 50 mM Tris/HCl; 10 mM EDTA pH=8.0.

- Solución P2: $0.2 \mathrm{M} \mathrm{NaOH;}$ 1\% SDS. Esta solución se prepara en el momento de uso a partir de soluciones madre de $0,4 \mathrm{M} \mathrm{NaOH}$ y $2 \%$ SDS.

- Solución P3: $3 \mathrm{M}$ de Acetato de Potasio $\left(\mathrm{CH}_{3} \mathrm{CO}_{2} \mathrm{~K}\right) \mathrm{pH}=4,8$.

Se utilizó también el kit comercial Wizard Plus SV Minipreps -DNA Purification System(Promega, Madison, Wiscosin. USA) siguiendo el protocolo del fabricante.

\section{Digestión enzimática de los vectores de clonado}

Las reacciones de digestión se realizaron en volúmenes variables de entre 10 a $50 \mu \mathrm{l}$ dependiendo de la concentración del ADN a digerir. Se emplearon en general entre 0,2 $1,5 \mu \mathrm{g}$ de ADN, con un exceso de enzima de 2 a 10 veces por sobre la cantidad de ADN a digerir. Se realizaron en todos los casos reacciones de doble digestión, con un porcentaje de corte mayor al $75 \%$ de ambas enzimas en el buffer utilizado. Las reacciones de digestión se llevaron a cabo a $37^{\circ} \mathrm{C}$ durante 2 a 8 hs.

Las enzimas de digestiones utilizadas (Promega) en cada una de las construcciones fueron:

- Enzimas de restricción para pGEM-gP5: BamHI/ HindIII. Buffer de digestión E.

- Enzimas de restricción para pGEM-M: BamHI/Xhol. Buffer B.

- Enzimas de restricción para pGEM-N: BamHI/Xhol. Buffer B.

- Enzimas de restricción para pCDNA-gP5: BamHI/ HindIII. Buffer E. 
- Enzimas de restricción para pCDNA-M: BamHI/Xhol. Buffer B.

- Enzimas de restricción para pCDNA-N: BamHI/Xhol. Buffer B.

Las digestiones fueron corroboradas en geles de agarosa con el marcador de pares de bases $100 \mathrm{pb}$ ladder o $1 \mathrm{~Kb}$ ladder, según correspondiera.

\section{Purificación y cuantificación de los productos digeridos}

Para la purificación de los productos digeridos se sembró la mezcla de digestión en un gel de agarosa y se escindió la banda de gel conteniendo el producto de interés. Se empleó el kit comercial Wizard SV Gel and PCR Clean-Up System (Promega) y el protocolo allí descripto para la purificación del ADN del gel de agarosa. Los productos purificados fueron cuantificados en geles de agarosa o por espectrofotometría como fue descripto anteriormente y conservados a $-20^{\circ} \mathrm{C}$ hasta su empleo en la construcción de los vectores de expresión.

\section{Ligación de los genes de interés al vector de expresión pCDNA 3.1(+) y secuenciación}

Para todas las reacciones de ligación se utilizó la T4 DNA Ligasa (Promega). De acuerdo al protocolo de la misma se utilizaron aproximadamente $100 \mathrm{ng}$ de vector en cada una de las reacciones en proporciones molares de 1:1, 1:3 o 3:1 con cantidades de inserto de acuerdo a la formula descripta anteriormente para el vector pGEM $T$ easy. Por esto, se llevaron a cabo varias reacciones, manteniendo constante la masa de vector y variando la cantidad de inserto. Los volúmenes de reacción fueron de $10 \mu$, utilizando entre $0,1 \cup$ y $1 U$ de la enzima T4 ADN Ligasa y $1 \mu \mathrm{l}$ de buffer de ligación 10X. Las reacciones de ligación se 
realizaron durante toda la noche a $4^{\circ} \mathrm{C}$. Se incluyó también un control sin inserto, para poder estimar el aporte del vector no digerido o religado al número total de colonias obtenidas luego de la transformación. Finalmente, se inactivó la enzima a $70^{\circ} \mathrm{C}$ por $10 \mathrm{~min}$. La eficiencia de las reacciones de ligación al vector de expresión pCDNA 3.1(+) fue evaluada por PCR utilizando el par de cebadores M13.

En las transformaciones con el vector pCDNA 3.1(+), se empleó la cepa E.coli JM109. Con el objetivo de obtener células permeables al vector de expresión se realizó la competencia de las mismas, de la misma manera descripta anteriormente. Se tomó un volumen de $4 \mu l$ de cada una de las construcciones obtenidas y se adicionó a un tubo de microcentrífuga conteniendo las células competentes. Se incubó la mezcla en hielo por un período de 20 min, se sometió a shock térmico a $42^{\circ} \mathrm{C}$ por 90 seg. Se mantuvo en hielo por 5 min y se adicionó a las células JM109 $900 \mu \mathrm{l}$ de medio SOC (Triptona 20g/l; Extracto de levadura 5g/l; $\mathrm{NaCl}$ 0,5g/l; $10 \mathrm{ml}$ de $\mathrm{KCl} 250 \mathrm{mM} ; 5 \mathrm{ml} \mathrm{MgCl} 2$ 2M. y $10 \mathrm{ml}$ Glucosa 20 mM filtrada). Se incubaron las bacterias a $37^{\circ} \mathrm{C}$ por $1 \mathrm{~h}$ en agitación. Un volumen de $100 \mu \mathrm{l}$ de la transformación fue sembrado en placa LB conteniendo $70 \mu \mathrm{g} / \mathrm{ml}$ de ampicilina. Se incubaron las placas sembradas toda la noche a $37^{\circ} \mathrm{C}$.

Se seleccionaron colonias al azar y se determinó la presencia de los genes de interés por PCR con cebadores pCDNA. Se recuperaron colonias positivas y el ADN plasmídico fue purificado y secuenciado para confirmar el correcto marco de lectura de las construcciones recombinantes (Primers T7 y BGH) (Ver anexo Secuencias).

\section{Transfección con Lipofectamina 2000}


El proceso de transfección implica la introducción de un ADN exógeno a una célula eucariota. Previo al mismo fue necesario identificar las concentraciones de antibiótico citotóxicas. Para ello se inocularon monocapas celulares las cuales fueron sometidas a distintas concentraciones de geneticina (de 0,001 a 0,01 mg/ml). Estas placas se monitorearon hasta que se observó muerte celular por observación al microscopio óptico. Previo a la transfección se requirió tener los elementos a transfectar linearizados. Los pasos seguidos fueron los siguientes:

1. Se mezclaron $5 \mu \mathrm{g}$ ADN con medio sin suero ni antibiótico hasta completar $300 \mu \mathrm{L}$.

2. Se mezclaron $75 \mu \mathrm{L}$ de lipofectamina con medio sin suero ni antibiótico hasta completar $300 \mu \mathrm{L}$.

3. Se mezcló ADN con lipofectamina (volumen final $600 \mu \mathrm{L}$ ).

4. Se Incubó a temperatura ambiente por $30 \mathrm{~min}$.

5. Se agregó medio sin suero ni antibióticos hasta completar 1,2 mL.

6. Se retiró el medio de las células.

7. Se lavó con PBS.

8. Se agregaron $1,2 \mathrm{~mL}$ de medio sin suero ni antibióticos a las células.

9. Se agregó la mezcla de ADN y lipofectamina (volumen final 2,4 mL).

10. Se mezcló suavemente moviendo la placa.

11. Se Incubó por $5 \mathrm{~h}$.

12. Se agregaron $2,4 \mathrm{~mL}$ de medio con $2 \%$ suero sin antibiótico.

13. A las $48 \mathrm{~h}$ post-transfección se retiró el medio y se lo reemplazó con el medio selectivo. 
14. El medio de selección fue cambiado cada 3 días. La selección de clones finalizó al observar la muerte celular de las placas control por la presencia del antibiótico.

\section{Análisis de la expresión en geles de poliacrilamida}

Los distintos entramados de los geles de corrida se prepararon de acuerdo a la siguiente tabla. Las cantidades aquí enunciadas corresponden para la preparación de minigeles de $10 \times 10 \mathrm{~cm}$.

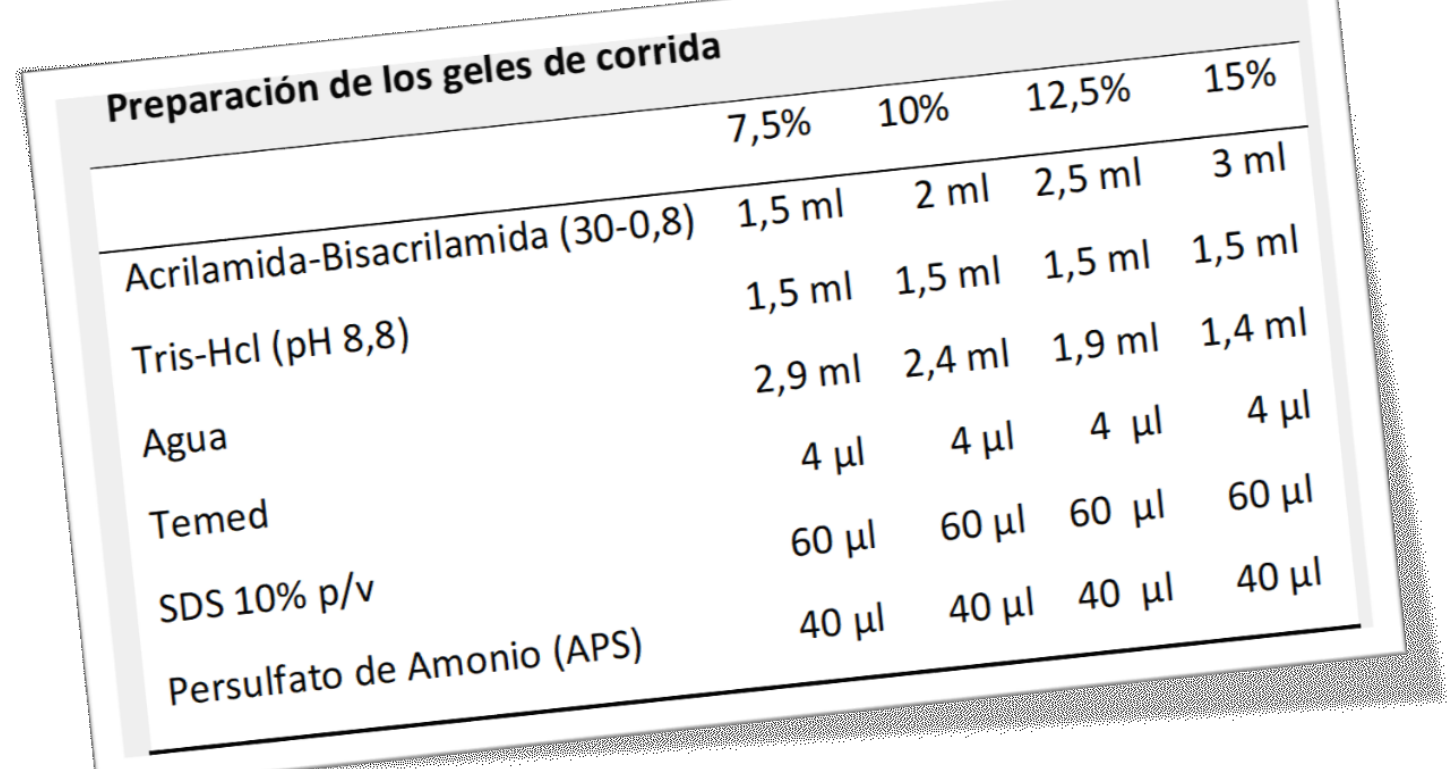

Tabla 4: Reactivos utilizados para la preparación de los geles de corrida. Se observan las cantidades utilizadas de cada compuesto de acuerdo al \% del gel esperado. En nuestro trabajo utilizamos geles al $12,5 \%$.

El porcentaje del gel de corrida se eligió en base al tamaño de las proteínas a separar. Tanto para la proteína N (12 kDa), M (20 kDa) y gP5 (30 kDa) se utilizaron geles de corrida de $12,5 \%$.

Para el caso del gel de apilamiento se utilizó la siguiente proporción de reactivos: 


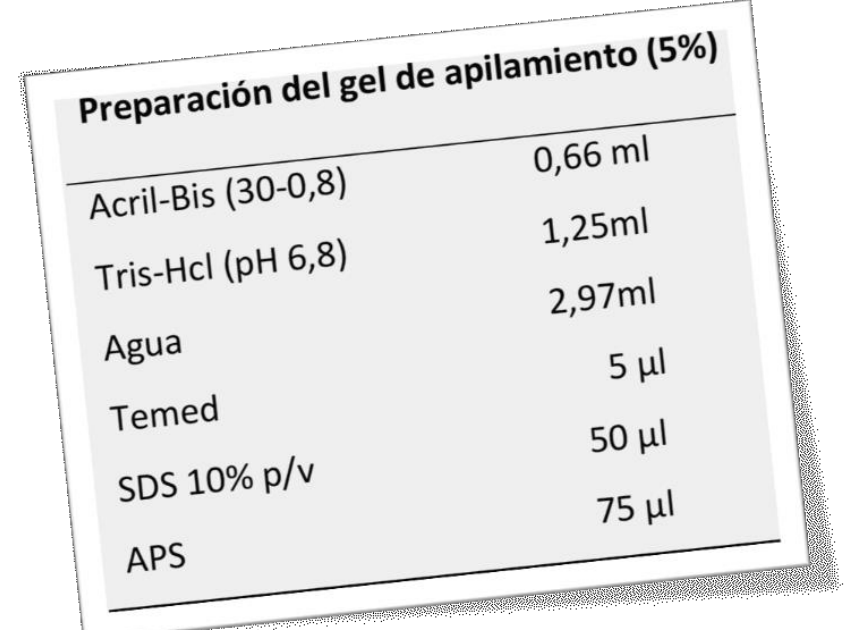

Tabla 5: Reactivos utilizados para la preparación del gel de apilamiento. Se observan las cantidades utilizadas de cada compuesto para obtener el gel al $5 \%$ esperado.

Para la preparación de las muestras, el pellet de cada una de las células transfectados y controles fue lavado 3 veces con solución de buffer fosfatos (PBS) (PBS: 50 mM Fosfato de potasio; 150 mM NaCl; pH 7.2) para eliminar los restos de medio. Se resuspendió en PBS y se agregó la misma proporción de buffer de carga. Las muestras fueron hervidas por 5 min y se centrifugaron, quedando listas para ser sometidas a electroforesis.

Los geles se armaron en cuba BioRad con buffer de corrida 1x. Se sembraron $20 \mu$ de muestra y se utilizó el marcador de peso molecular Page Ruler Prestained Protein Ladder (Fermentas). Para la tinción de los geles se empleó el sistema de tinción con Azul Brillante de Coomasie. El gel fue sumergido en esta solución entre 4 a 6 hs a $37^{\circ} \mathrm{C}$ en agitación. Y luego desteñido en agitación suave a temperatura ambiente.

Las soluciones stock para preparar los geles de acrilamida fueron las siguientes:

- Solución Acrilamida-Bisacrilamida: Acrilamida 30 g; Bisacrilamida 0,8 g; Agua CSP $100 \mathrm{ml}$. 
- Buffer Tris-HCl 1,5M pH 8,8: Tris 18,15 g; HCl para llevar a pH 8,8; Agua CSP 100 ml.

- Buffer Tris-HCl 0,5M pH 6,8: Tris $3 \mathrm{~g} ; \mathrm{HCl}$ para llevar a pH 6,8; Agua CSP $100 \mathrm{ml}$.

- Persulfato de Amonio al 1\%: 0,05 g de APS en 0,5 ml de agua.

- Buffer de corrida 10x: Tris 30,2g; Glicina 144 g; Agua CSP 1000 ml.

- Buffer de corrida 1x: $100 \mathrm{ml}$ buffer de corrida 10x + $10 \mathrm{ml}$ SDS 10\% + Agua CSP $1000 \mathrm{ml}$.

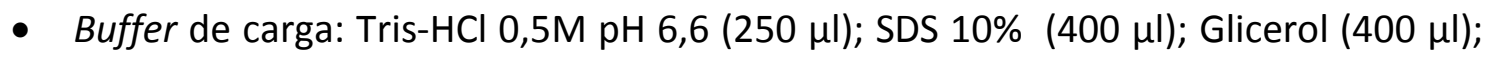
Azul de Bromofenol 0,1\% p/v (20 $\mu \mathrm{l}) ;$ Agua $(850 \mu \mathrm{l}) ; \beta$-mercaptoetanol (100 $\mu \mathrm{l})$ (Para preparar el buffer en condiciones no reductoras se reemplaza el $\beta$ mercaptoetanol por agua).

- Solución de teñido: Azul Brillante de Coomasie 0,1 g; Metanol 41,7 ml; Ácido acético glacial 16,6 ml; Agua 41,7 ml.

- Solución de desteñido: Metanol 300 ml; Ácido acético 100 ml; Agua 600 ml.

\section{Análisis de la expresión por Western blot}

Luego de la corrida electroforética, se equilibró el gel en buffer de transferencia, a fin de facilitar la remoción de sales y detergentes del buffer de corrida. Se cortaron membranas de nitrocelulosa (Sigma) de 0,45 $\mu \mathrm{m}$ y papel de filtro del tamaño del gel las que también fueron humedecidas en buffer de transferencia para asegurar la correcta adhesión de las moléculas al soporte. Se armó el "sándwich" de transferencia evitando la formación de burbujas entre los distintos componentes. La electrotransferencia se realizó en sistema semiseco (BioRad) a $15 \mathrm{~V}$ durante $30 \mathrm{~min}$. 
Finalizado el tiempo de transferencia se retiró la membrana y se incubó toda la noche a $4^{\circ} \mathrm{C}$ en solución de leche descremada para bloquear los sitios libres de la membrana donde no hubiera proteína unida.

Luego del bloqueo, la membrana fue lavada 3 veces durante de 5 min con PBS-Tween 20 0,1\% para eliminar los restos de solución de bloqueo.

Para la detección de las proteínas, se utilizaron los Ac primarios y secundarios detallados en la siguiente tabla. Se indica también la dilución de uso de cada uno de ellos:

\begin{tabular}{|c|c|}
\hline Anticuerpo primario & Anticuerpo secundario \\
\hline Sueros policlonales anti VAE & Anti equino conjugado con peroxidasa (Sigma) \\
Dil: $1 / 100-200$ & Dil: $1 / 500-1 / 1000$ \\
\hline $\begin{array}{c}\text { Suero policlonal anti caspasa-3 (L-18, sc*-1225, } \\
\text { Lote:JO115). Dil: } 1 / 100\end{array}$ & Anti cabra conjugado con peroxidasa (Sigma) \\
Suero policlonal anti caspasa-8 (P-18, sc*-4778, \\
Lote:HO515). Dil: $1 / 100$ \\
Suero policlonal anti caspasa-9 (P-10, sc*-8297, \\
Lote:K1010). Dil: $1 / 100$ \\
sc*: Santa Cruz Biotechnology
\end{tabular}

Tabla 6: Anticuerpos y sus diluciones empleados en la inmunodetección. Se observan los sueros anti VAE y anti caspasa-3, -8 y -9 utilizados, con sus correspondientes anticuerpos secundarios.

La membrana se incubó entre 1-3 h a temperatura ambiente con cada uno de los Ac. Entre cada una de las incubaciones se realizaron 3 lavados de 5 min con PBS-Tween 20 0,1\%.

Para el revelado de la reacción se empleó Diaminobenzidina (DAB) (Sigma) y agua oxigenada como sustrato de la enzima peroxidasa. 
Las soluciones utilizadas en la técnica de Western Blot (WB) se detallan a continuación:

- Solución de Bloqueo: 5\% de leche en polvo (Gibco) en PBS-Tween 20 0,1\%.

- Solución diluyente: 3\% de leche en polvo (Gibco) en PBS-Tween 20 0,1\%.

- Solución de lavado: PBS Tween 20 0,1\%.

- Solución de revelado: 30 mg de DAB y disolver en 100 ml de PBS. Agregar $30 \mu \mathrm{l}$ de $\mathrm{H}_{2} \mathrm{O}_{2} 30 \mathrm{Vol}$ como catalizador. Frenar la reacción de revelado con agua corriente.

\section{Análisis de la transcripción de los ARNs mensajeros de los genes clonados}

Para analizar la expresión de los ARNm en las células transfectados, se procedió al tripsinado de las células cultivadas. Luego de una centrifugación suave (1000 rpm por 5 min), el pellet fue lavado dos veces con PBS y la extracción de ARN celular fue realizada utilizando el kit comercial (Zimo Research). Los ADNc se sintetizaron a partir del ARN total obtenido en el punto anterior mediante transcripción reversa utilizando hexámeros al azar como cebadores y transcriptasa reversa del virus de la leucemia murina de Maloney (MMLV).

La técnica de PCR Retrotranscriptasa (RT-PCR) se realizó en dos fases. En la primera de ellas se mezclaron $5 \mu \mathrm{l}$ del ARN con $1 \mu \mathrm{l}$ de hexámeros al azar y $9 \mu \mathrm{l}$ de agua libre de nucleasas. Las muestras fueron incubadas en bloque térmico a $70^{\circ} \mathrm{C}$ durante 5 min para permitir la hibridización de los hexámeros. En una segunda fase se agregó al tubo de reacción: $1 \mu \mathrm{l}$ de MMLV, $5 \mu \mathrm{l}$ del buffer de la enzima MMLV, $1 \mu$ del inhibidor de la ARNasa, $1 \mu \mathrm{l}$ de nucleotidostrifosfatos (dNTP`s) y $2 \mu \mathrm{l}$ de agua libre de nucleasas. Se 
incubó la mezcla 60 min a $37^{\circ} \mathrm{C}$ y se sometió a un ciclo final de desnaturalización de la enzima a $9490 \mathrm{C}$ por 5 min en termociclador Eppendorf Mastercycler Gradient.

El ADNc obtenido se utilizó como molde para las PCR con los cebadores específicos de cada gen viral. Las reacciones de PCR se realizaron en equipo Eppendorf Mastercycler Gradient. Se confeccionaron cada uno de los ciclos de PCR acorde al par de cebadores utilizados, repitiendo cada uno de ellos entre 25 a 35 veces por programa, con las temperaturas, tiempos y productos esperados detallados en la Tabla 3.

\section{Detección de apoptosis por fragmentación del ADN}

EI ADN fue extraído de todas las muestras siguiendo el protocolo fenol/cloroformo. Primeramente, los pellets celulares fueron lavados y resuspendidos en buffer TEN (Tris- HCl 100 mM (pH 7,5), NaCl 150 mM, EDTA 12 mM (pH 8,0) y SDS al 1\%). Luego se agregó proteinasa $\mathrm{K}(0,2 \mathrm{mg} / \mathrm{ml})$ y se incubaron durante $4 \mathrm{~h}$ a $50^{\circ} \mathrm{C}$. El lisado se extrajo con buffer TE (Tris-HCl 10 mM y EDTA 1 mM (pH 8,0)), fenol saturado, y con una mezcla de fenolcloroformo-isoamilalcohol (25:24:1). Finalmente, se precipitó el ADN total con dos volúmenes de etanol al $99 \%$, fue aclarado dos veces con etanol al $70 \%$, secado y resuspendido en $40 \mu \mathrm{l}$ de agua destilada estéril. Las muestras fueron corridas en un gel de agarosa al $1 \%$ con un marcador de peso molecular 100 pb (Promega) y se tiñeron con bromuro de etidio para visualizar la fragmentación del ADN.

\section{Detección de apoptosis por tinción diferencial (NA/BE)}


Colocamos cubreobjetos de $18 \times 18 \mathrm{~mm}$ en placas de Petri de $3,5 \mathrm{~cm}$ de diámetro y los sembramos con $10^{6}$ células de cada cultivo celular. Las células infectadas fueron incubadas según lo descrito anteriormente. Posteriormente, cada cubreobjetos fue lavado con una solución de PBS y sometido a la coloración de NA/BE (Sigma-Aldrich) (Kasibhatla y col., 2006). Como control negativo se utilizaron monocapas de cultivos celulares no infectadas y como control positivo, monocapas celulares donde la apoptosis fue inducida por medio de staurosporina (STS) a una concentración de $1 \mu \mathrm{g} / \mathrm{ml}$ (Santa Cruz Biotechnology, CA, EEUU). Todas las pruebas se realizaron por duplicado.

En cada cubreobjetos se agregó una dilución 1/10 de una solución de NA 100 mg/ml y BE $100 \mathrm{mg} / \mathrm{ml}$ en PBS durante $2 \mathrm{~min}$. Luego de eliminarse la solución se montaron los cubreobjetos en portaobjetos limpios que fueron examinados mediante microscopía de fluorescencia (Microscopio Olympus modelo BHS).

\section{Detección de apoptosis por citometría de flujo}

Las muestras se procesaron para citometría de flujo siguiendo el protocolo comercial disponible online (Thermo Fisher Scientific). Una vez resuspendido el pellet de células en el buffer comercial, las células fueron marcadas con $5 \mu \mathrm{l}$ Anexina V-FICT $(100 \mu \mathrm{g} / \mathrm{ml}$, BioLegand)/1 $\mu$ l loduro de propidio $(50 \mu \mathrm{g} / \mathrm{ml}$, Thermo Fisher Scientific) y sometido a citometría. Después de 10 min de incubación en la oscuridad, se detectaron las señales

fluorescentes emitidas por Anexina V/FITC e IP mediante un clasificador de células activadas por fluorescencia. Las señales emitidas por Anexina V-FICT fueron captadas por el filtro FL1-H, mientras que las propias del loduro de propidio por el filtro FL2-H (FACScan, 
Instituto de Estudios Inmunológicos y Fisiopatológicos, FCE-UNLP-CONICET; FACSCalibur, Morrison Virology Center, Lincoln, Nebraska, USA). Los desechos celulares fueron excluidos de los análisis por el método Scatter. Luego de analizar 10.000 eventos, los resultados se graficaron utilizando el programa informático Flow Jo. En algunos estudios de citometría también evaluamos el porcentaje de células apoptóticas de los cultivos transfectados tras la infección de los mismos con el virión completo (para ello infectamos los distintos cultivos celulares con MOI de 1 de la cepa Bucyrus) o el tratamiento con STS a una concentración de $1 \mu \mathrm{g} / \mathrm{ml}$.

\section{Detección de caspasas-3,-8 y-9 in situ por inmunotinción}

Para detectar la activación de caspasas, se utilizó la misma metodología descrita para los estudios morfológicos mediante la tinción de NA/BE. Los cubreobjetos con cada cultivo celular fueron incubados con diversos Ac para caspasas: IgG anti-caspasa-3 policlonal de cabra (L-18), IgG anti-caspasa-8 policlonal de cabra (P-18) e IgG anti-caspasa-9 policlonal de cabra (P-10) (Santa Cruz Biotechnology). Todos los Ac fueron utilizados diluidos a razón 1:100 en PBS.

Para evidenciar el reconocimiento del Ac secundario (IgG anti-cabra de conejo conjugado con HRP (Sigma-Aldrich, St. Louis, EEUU; diluido 1:500 en PBS) se utilizó Amino Etil Carbazol (AEC) (Sigma-Aldrich St. Louis, EEUU) como sustrato para la enzima peroxidasa de rábano picante, revelándose la reacción enzimática con un precipitado rojizo. Una solución de $3 \mathrm{mg}$ de AEC disuelta en $750 \mu \mathrm{l}$ de N,N- dimetilformamida se agregó a 14,25 $\mathrm{ml}$ de buffer acetato (21 $\mathrm{ml}$ de ácido acético $0.1 \mathrm{~N}$ y $79 \mathrm{ml}$ de acetato de sodio 0,1N), 
finalmente se agregó $150 \mu$ l de peróxido de hidrógeno en el momento de utilización. Los diferentes cubreobjetos fueron cubiertos con la solución de revelado por 3 min. Transcurrido este tiempo, la reacción se detuvo al añadir PBS. Cada cubreobjetos fue colocado en un portaobjeto limpio y examinado por microscopía invertida (Microscopio Olympus Modelo BHS). 

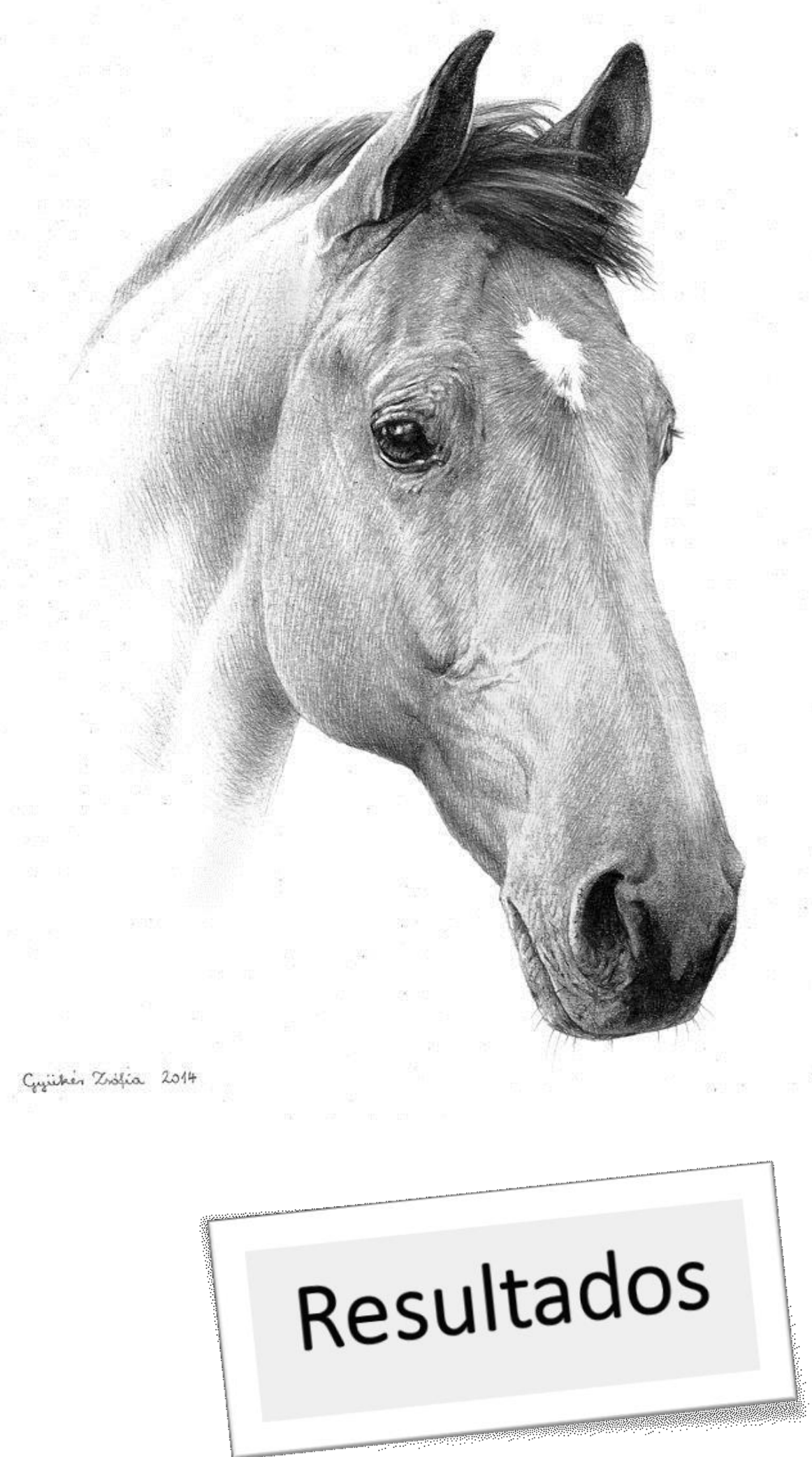


\section{Capítulo I: \\ Apoptosis observada en cultivos infectados con los \\ viriones del VAE completos y controles}

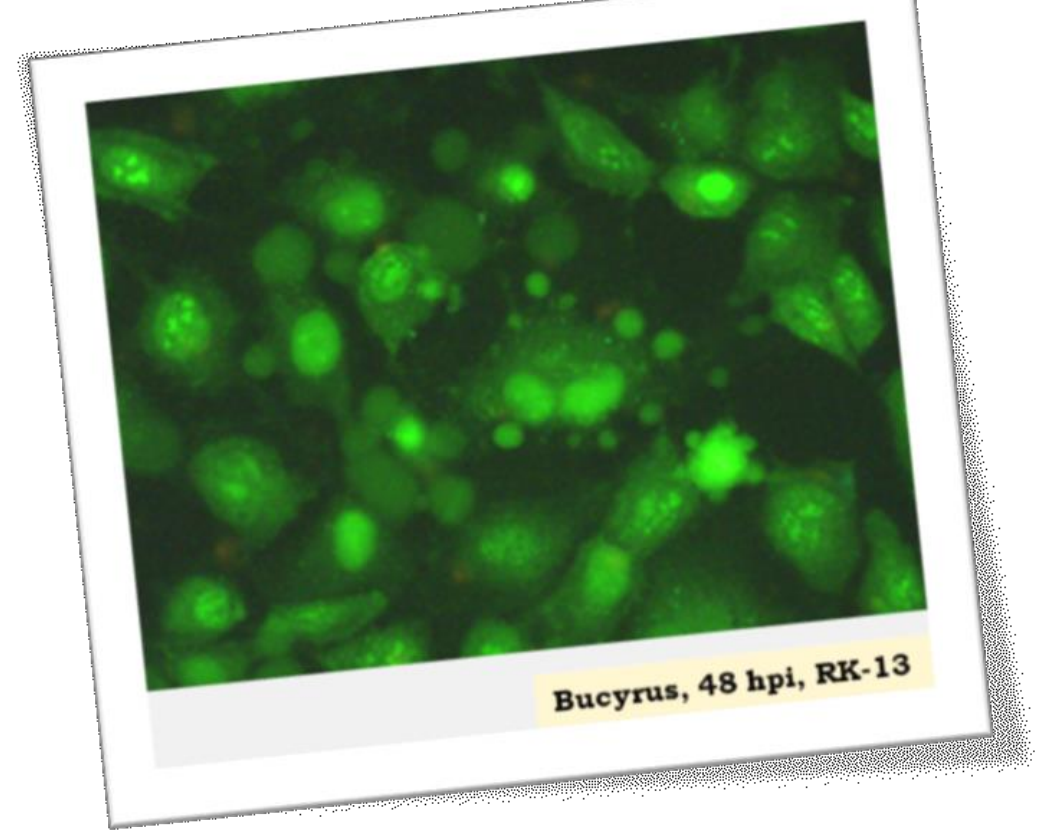


1 Características morfológicas de apoptosis en las células infectadas con el VAE y controles tras la tinción con NA/BE (cualitativo)

2 Detección de la apoptosis mediante análisis de citometría de flujo utilizando Anexina V-FICT+ loduro de propidio (cuantitativo)

Como primer paso decidimos analizar la apoptosis utilizando el virión completo de las tres cepas virales (Bucyrus, LP-01 y GLD-LP-ARG) e infectamos los cultivos celulares que planteamos utilizar en este plan de tesis doctoral (RK-13, Vero, BHK-21). También incluimos en este capítulo los controles positivos (cultivos tratados con STS) y negativos (cultivos sin infectar), según la metodología descripta anteriormente.

1 Características morfológicas de apoptosis en las células infectadas con el VAE y controles tras la tinción con NA/BE (cualitativo)

La tinción con NA/BE permite diferenciar células en distinto estadio biológico, por su tinción diferencial y por la capacidad para delinear el contorno y contenido celular. El colorante vital $\mathrm{BE}$, debido a su alto PM, solo ingresa a las células cuya membrana plasmática tenga soluciones de continuidad, confiriendo una coloración anaranjada, por lo tanto su presencia es evidenciada en las células necróticas. El colorante NA es muy difusible y penetra en todas las células. La combinación NA/BE permite caracterizar los tres estadios importantes para nuestro estudio: células viables (NA+/BE-: células verdes, morfología normal), células apoptóticas (NA+/BE-: células verdes, morfología típica de apoptosis) y células necróticas (NA+/BE+: células con contenido anaranjado). Es importante recalcar que, debido a que se trata de un cultivo celular, las células 
apoptóticas no pueden ser fagocitadas (como ocurriría en un organismo vivo), es por ello que sufren necrosis secundaria, tomando su contenido citosólico la coloración anaranjada del BE. Estas últimas células serán consideradas como apoptóticas siempre que expresen la morfología típica de esta muerte celular. En la Figura 6 se observan los cultivos celulares infectados con distintas cepas del VAE, a diferentes tiempos pi y los controles negativos (cultivos sin infectar) y positivos (tratados con STS) correspondientes, sometidos a la tinción NA/BE. Las flechas blancas señalan células viables (NA+/BE); las flechas amarillas indican las células y cuerpos apoptóticos (NA+/BE-), y por último, las flechas rojas apuntan a las células necróticas ( $\mathrm{NA}+\mathrm{BE}+)$. 

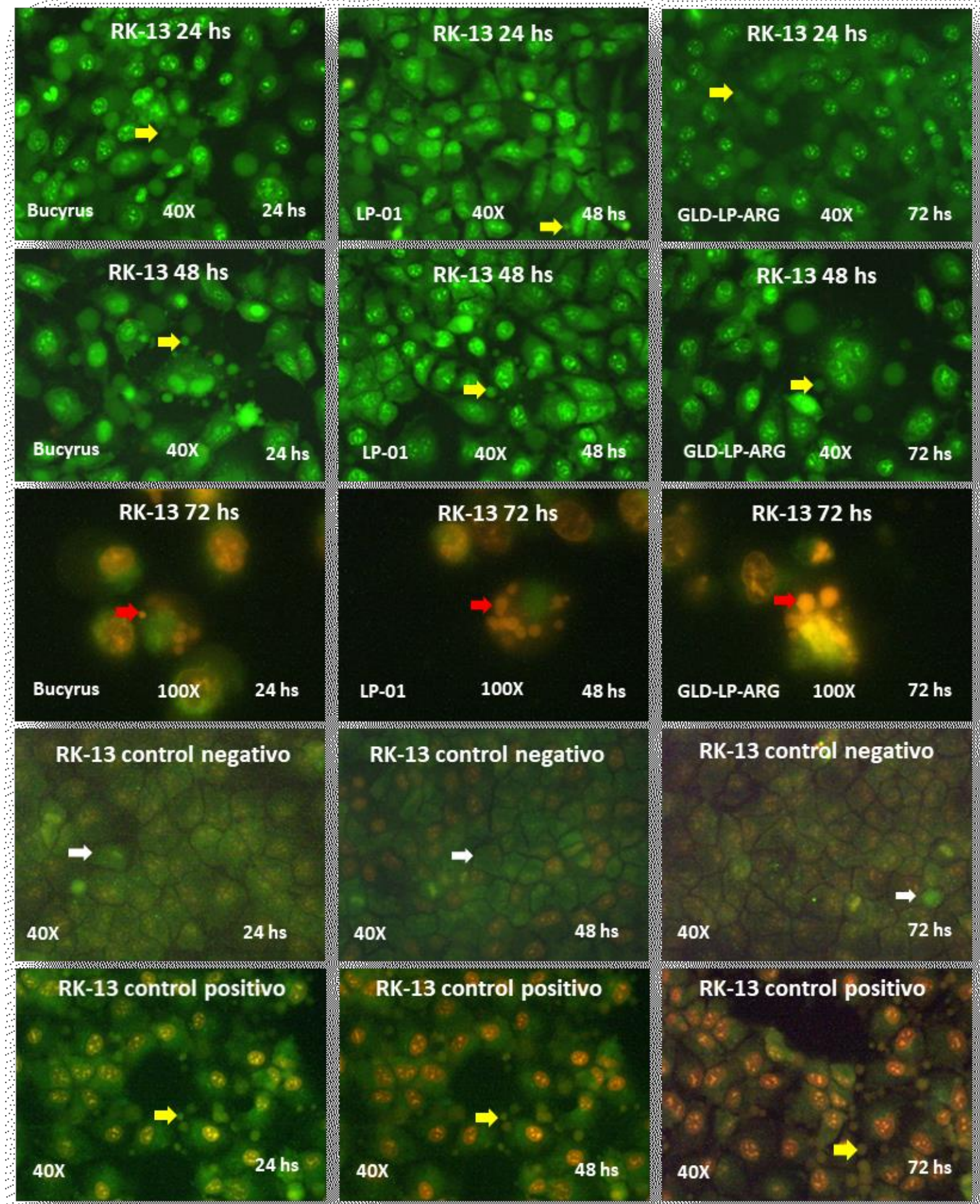

$40 \mathrm{X}$
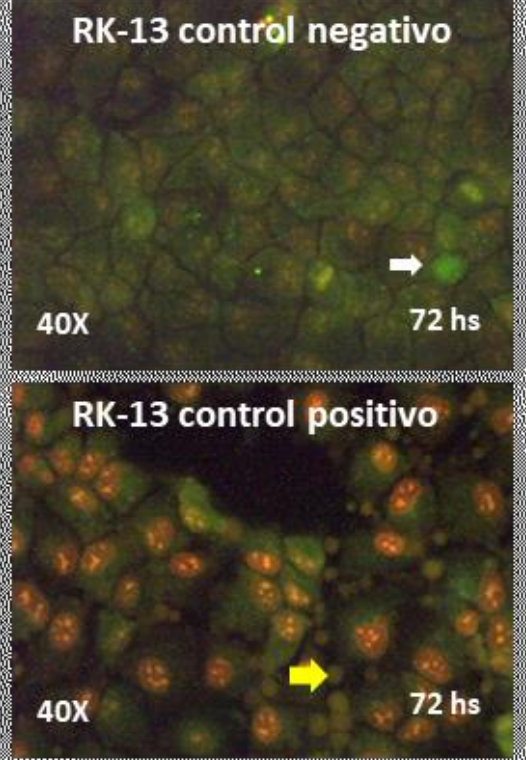

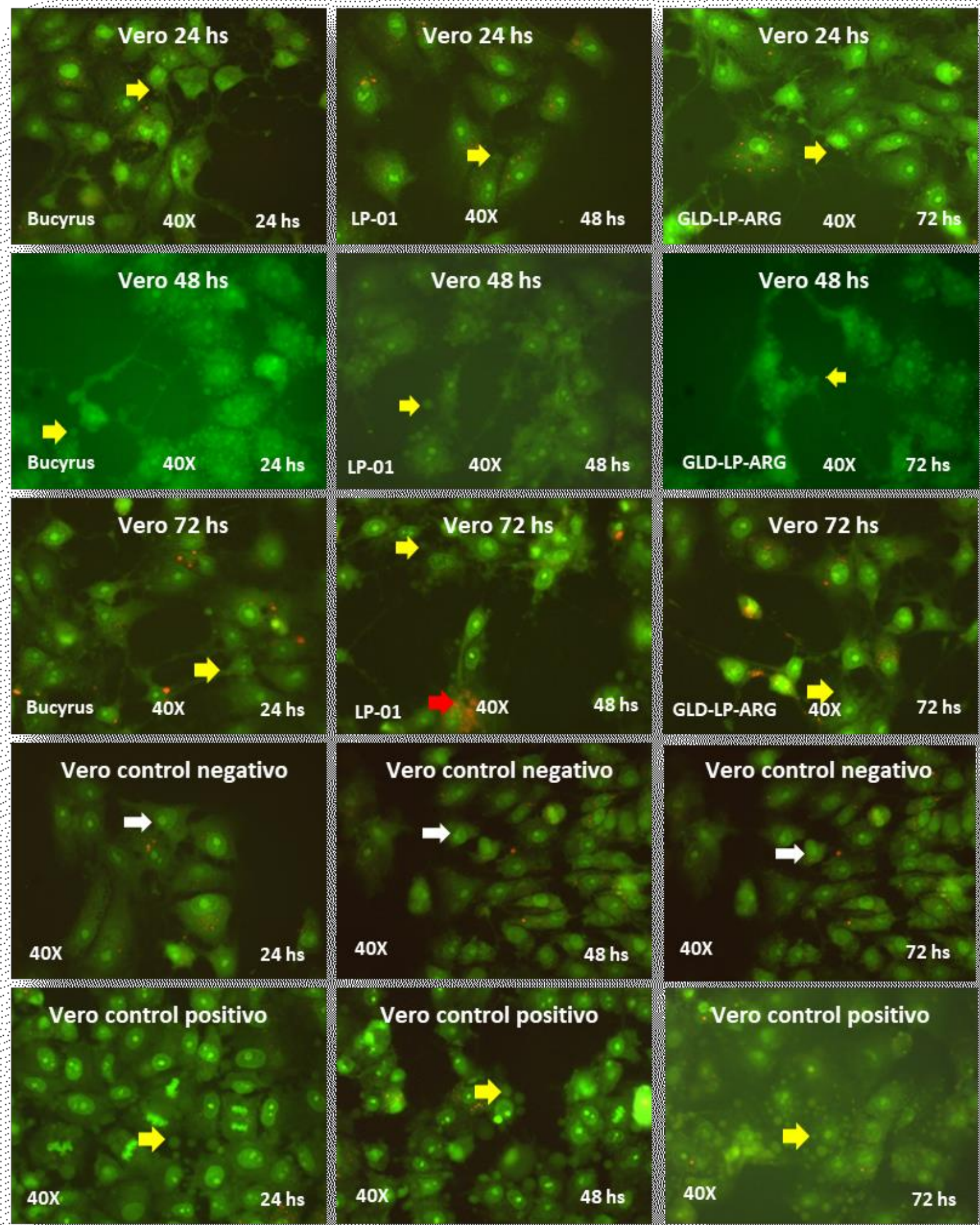


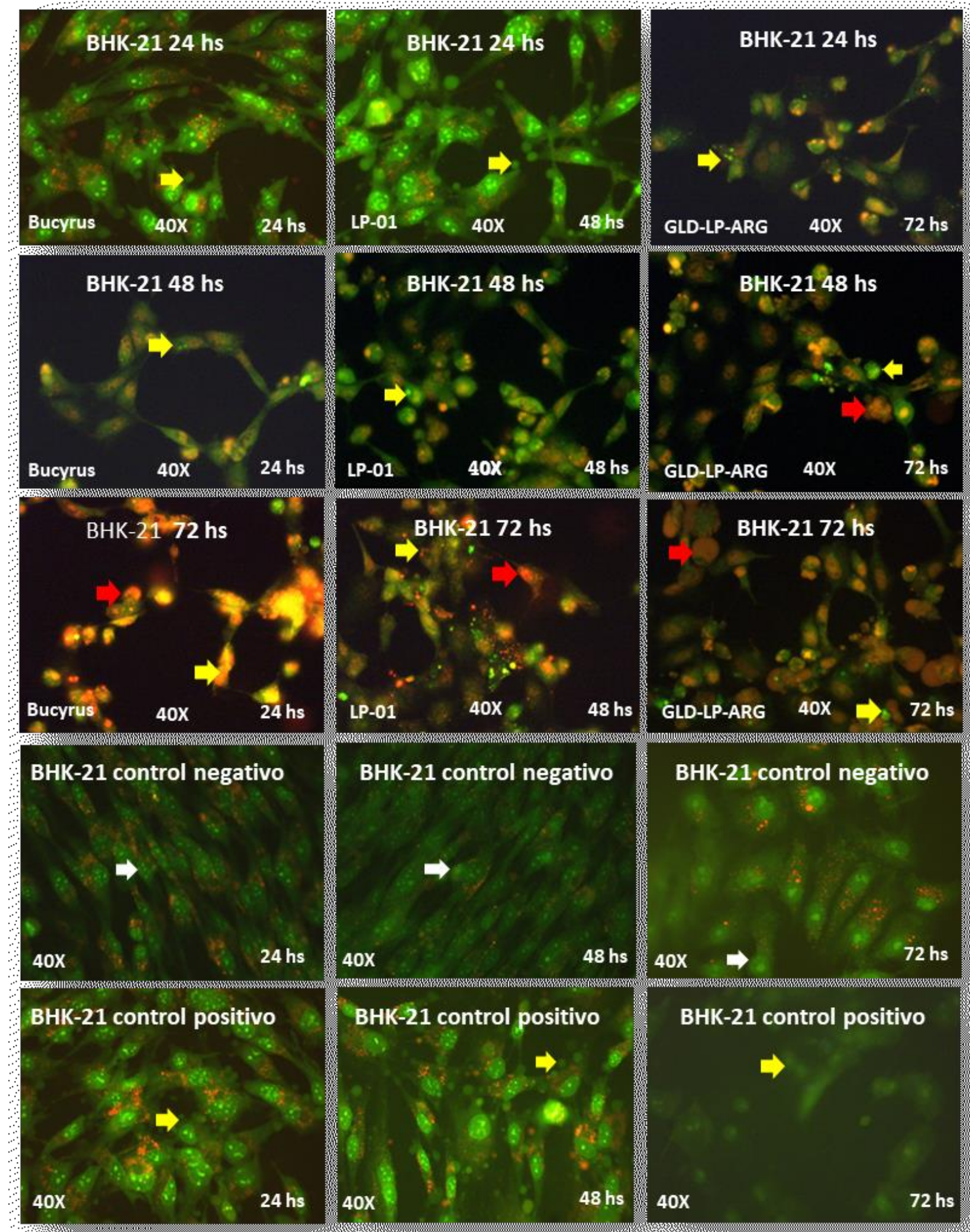


Figura 6: Tinción NA/BE de cultivos celulares infectados con distintas cepas del VAE, a diferentes tiempos pi y controles. Se observan señaladas con flechas blancas las células viables (NA+/BE-); con flechas amarillas se indican células y cuerpos apoptóticos (NA+/BE-) y con flechas rojas se muestran células necróticas $(\mathrm{NA}+/ \mathrm{BE}+$ ), en las tres lineas celulares evaluadas. Es evidente la mayor aparición de celulas apoptóticas y con necrosis secundaria a medida que transcurren las horas pi. Además se aprecian que los cultivos RK-13 infectados con la cepa Bucyrus manifiestan en forma muy marcada las características morfológicas típicas de apoptosis, si bien estas se observan en todos los cultivos infectados por las distintas cepas del VAE.

Las caracteristicas morfológicas típicas de apoptosis, similares a las observadas en los controles positivos, se detectaron en todas las líneas celulares infectadas, a los diferentes tiempos pi evaluados. Concluimos que las tres cepas virales evaluadas inducen apoptosis en las tres líneas celulares infectados.

Se decidió cuantificar la apoptosis observada, para lo cual se recurrió a la técnica de citometría de flujo. Se utilizaron dos MOI diferentes de cada una de las cepas virales, con el objetivo de relacionar patogenicidad y dosis infectante viral con la apoptosis cuantificada.

\section{Detección de la apoptosis mediante análisis de citometría de flujo utilizando Anexina}

\section{V-FICT+ loduro de propidio (cuantitativo)}

La citometría de flujo nos permite cuantificar las diferentes poblaciones celulares infectadas ya evidenciadas con la tinción NA/BE. Las muestras fueron cultivadas en condiciones comparables con el ensayo cualitativo NA/BE y se procesaron para citometría siguiendo el protocolo comercial. En los estudios de citometría también evaluamos el efecto de la MOI en el porcentaje de células apoptóticas. Para ello infectamos los distintos cultivos celulares con $\mathrm{MOI} 0,5$ y 5 , de cada cepa viral.

Como fluorocromos se utilizaron: 
- Anexina V-FICT: Ac anti-fosfatidilserina, marcado con FICT. La fosfatidilserina es un fosfolípido de membrana plasmática que normalmente se encuentra en la cara interna de la misma, pero en una célula apoptótica su translocación a la membrana externa es uno de los eventos bioquímico más tempranos.

- loduro de Propidio: fluorocromo que por su gran PM solo puede penetrar en las células cuya membrana plasmática este irreversiblemente dañada, es decir células en necrosis.

Los datos informáticos arrojados por el citómetro FACScan fueron graficados utilizando el programa FlowJo. En cada gráfico obtenido las poblaciones celulares se encuentran divididas en cuatro cuadrantes de la siguiente manera:

- Los inferiores izquierdos (Q4) representan a las células intactas (Anexina V-/IP-), es decir, representan el porcentaje de supervivencia celular en cada experimento.

- Los inferiores de la derecha (Q3) representan las células con apoptosis temprana (Anexina V+/IP-).

- Los superiores a la derecha (Q2) se refieren a las células con apoptosis tardía y/o necróticas (Anexina $\mathrm{V}+, \mathrm{IP}+$ ).

- Los superiores a la izquierda (Q1) no se analizan, por convención.

En la Figura 7 se observan las células infectadas con distintas cepas del VAE, a diferentes tiempos pi y los controles negativos (cultivos sin infectar) y positivos (tratados con STS) correspondientes. El panel A representa los datos obtenidos en las células RK-13, el panel B los obtenidos en la línea VeroE6 y el panel C los resultados arrojados en las BHK-21. 


\section{A}

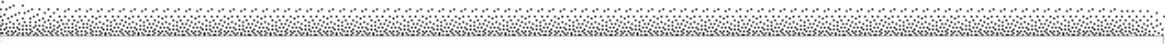
Control (-): $8,24 \%$
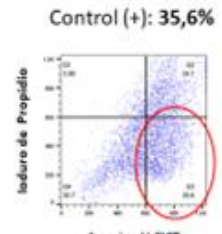

Anexina v-ACr
EAV Bucyrus MOI 0,5: $27 \%$

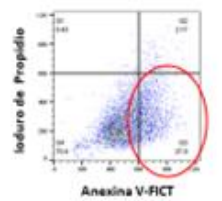

Anevina V-ACT
EAV Bucyrus MOI 5: 37,4\%

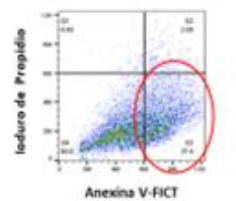

RK-13: 24 hs

EAV LP\01 MOI 0,5: 12,1\% EAV LP\01 MOI 5: 27\%) EAV GLD-LP-ARG MOI 0,5: 23,7\% EAV GLD-LP-ARG MOI 5: 35,1\%
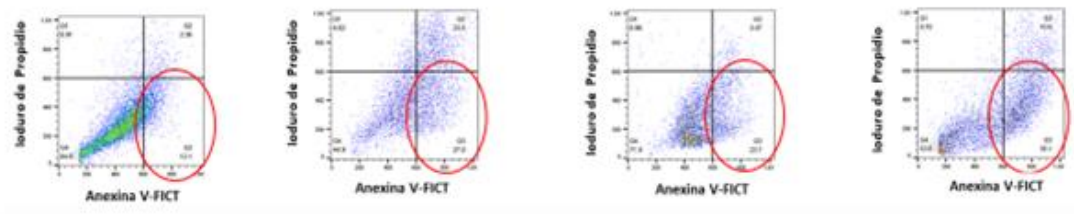

Control (-): $17,2 \%$

Control $(+): 47,4 \%$

EAV Bucyrus MOI 0,5: $29,9 \%$

EAV Bucyrus MOI 5: 47,9 \%
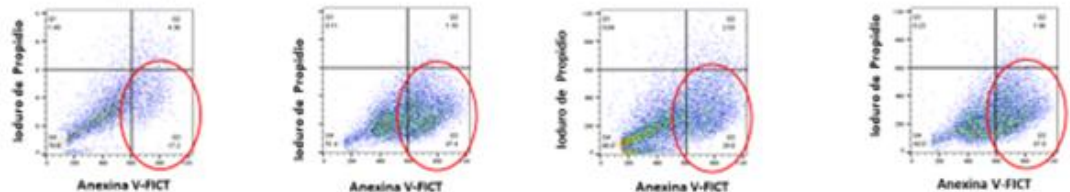

RK-13: 48 hs

EAV LP\01 MOI 0,5: 16,8\% EAV LP\01 MOI 5: 29,5\% EAV GLD-LP-ARG MOI 0,5: 28,6\% EAV GLD-LP-ARG MOI 5: 43,5\%
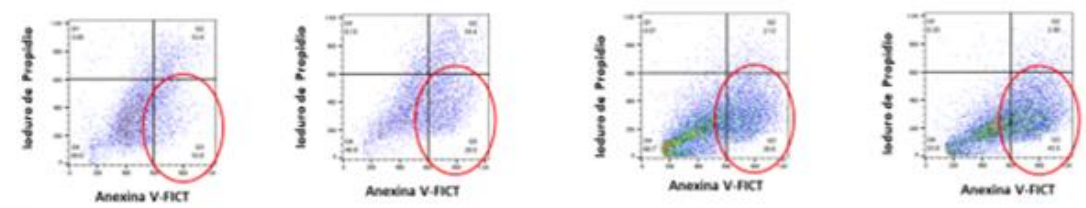

Control (-): $26,4 \%$

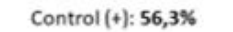

EAV Bucyrus MOI 0,5: $48,5 \%$

EAV Bucyrus MOI 5: 55,6\%
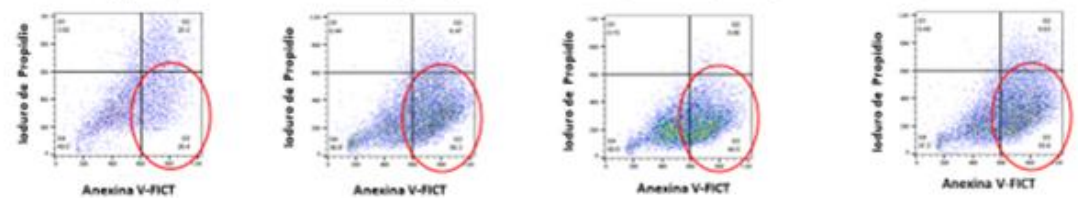

RK-13: 72 hs

EAV LPI01 MOI 0,5: 32,1\% EAV LPI01 MOI 5: 41,3\% EAV GLD-LP-ARG MOI 0,5: 45,2\% EAV GLD-LP-ARG MOI 5: 49,1\%
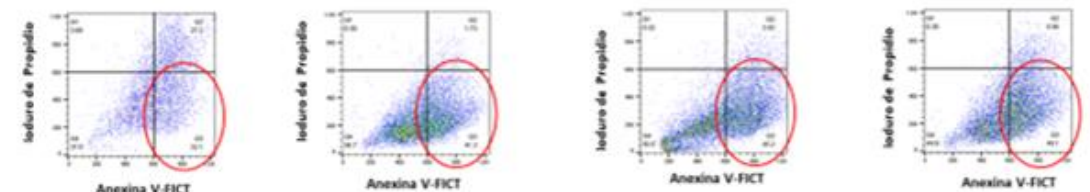


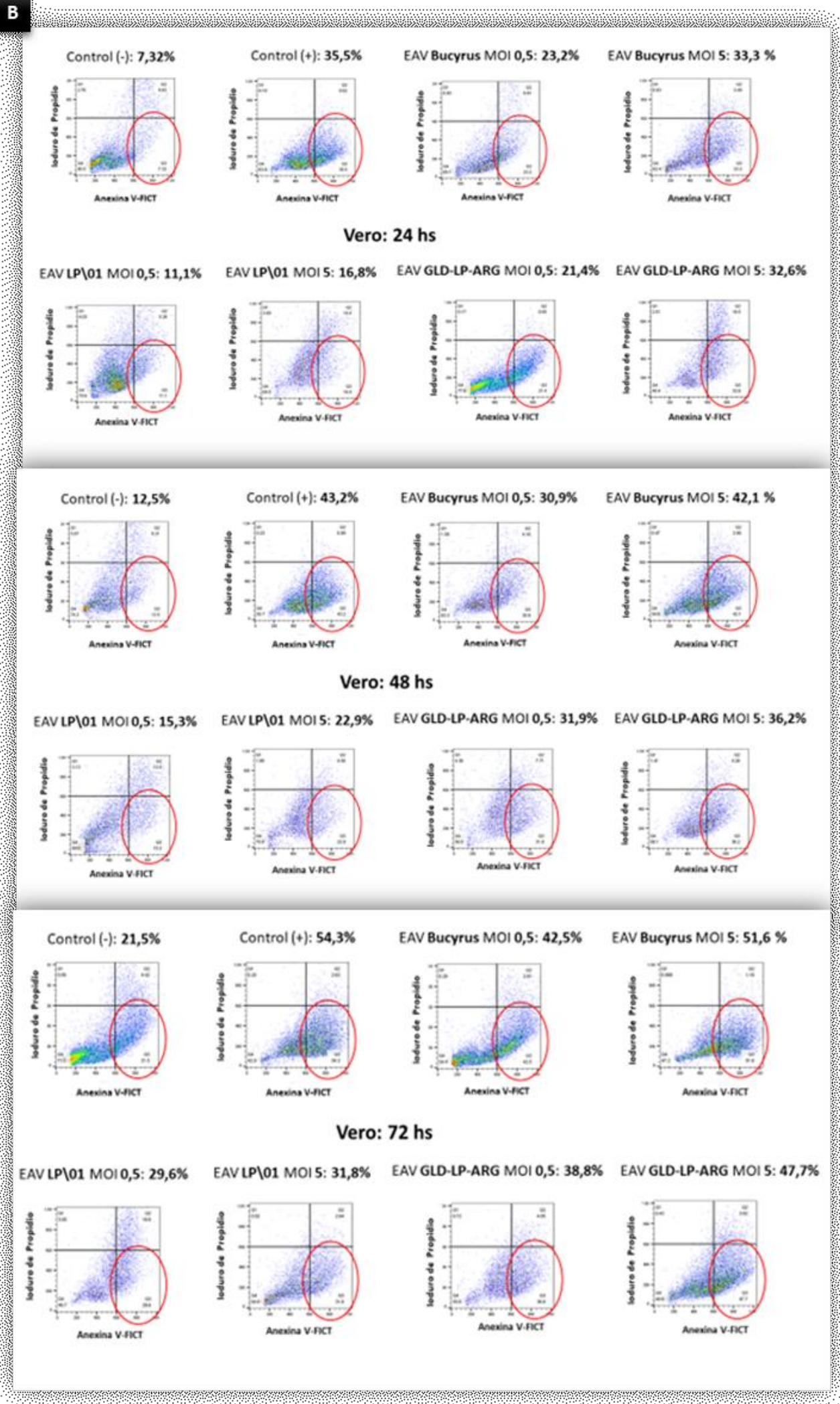


c

$6+3$

Control $(-): 6,65 \%$

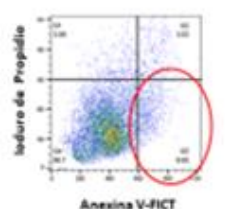

Control (+): $23 \%$

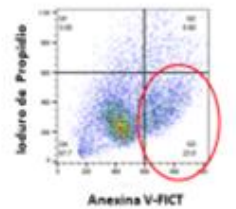

EAV Bucyrus MOI 0,5: 9,9\%

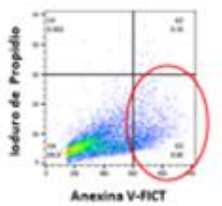

EAV Bucyrus MOI 5: $12,7 \%$

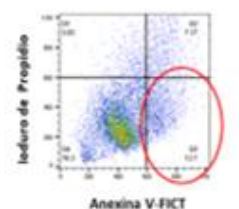

BHK-21: 24 hs

EAV LP\01 MOI 0,5: 6,71\%

EAV LP\01 MOI 5: 7,84\% EAV GLD-LP-ARG MOI 0,5: 6,94\%

EAV GLD-LP-ARG MOI S: $10,4 \%$
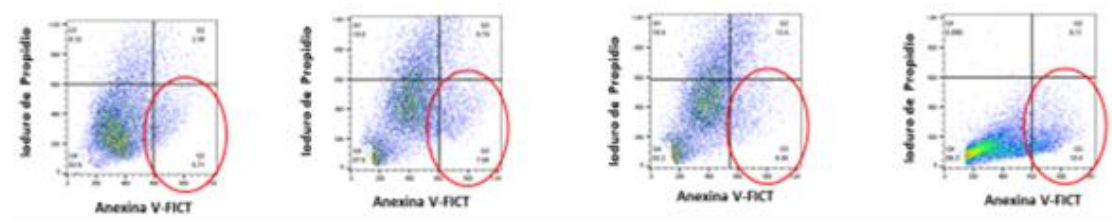

Control (-): $7,83 \%$

Control (+): $26,8 \%$

EAV Bucyrus MOI 0,5: $13,5 \%$

EAV Bucyrus MOI 5: 15,4\%
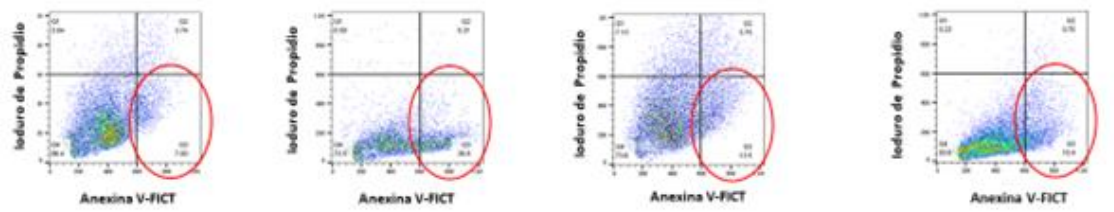

BHK-21: 48 hs

EAV LP\01 MOI 0,5: 6,93\%

EAV LP\01 MOI 5: $8,74 \%$

EAV GLD-LP-ARG MOI 0,5: 11,9\%

EAV GLD-LP-ARG MOI S: $13,2 \%$
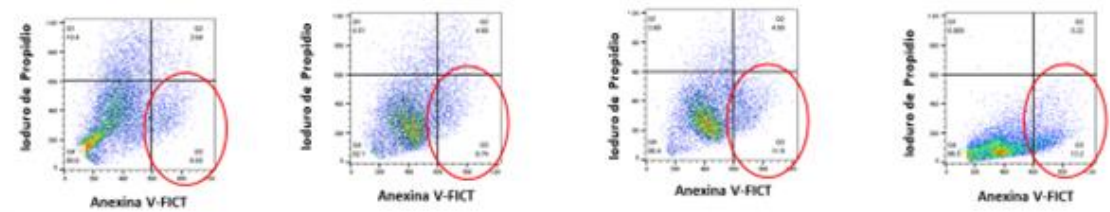

Control $(-) ; 8,25 \%$

Control (+): $32,8 \%$

EAV Bucyrus MOI 0,5: $15,8 \%$

EAV Bucyrus MOI 5: $18,1 \%$
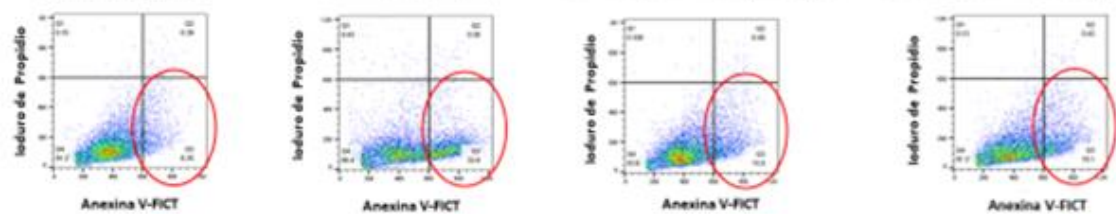

BHK-21: 72 hs

EAV LPI01 MOI 0,5: $8,36 \%$

EAV LP\01 MOI 5: $10,3 \%$

EAV GLD-LP-ARG MOI 0,5: $14,7 \%$

EAV GLD-LP-ARG MOI 5: $16,4 \%$
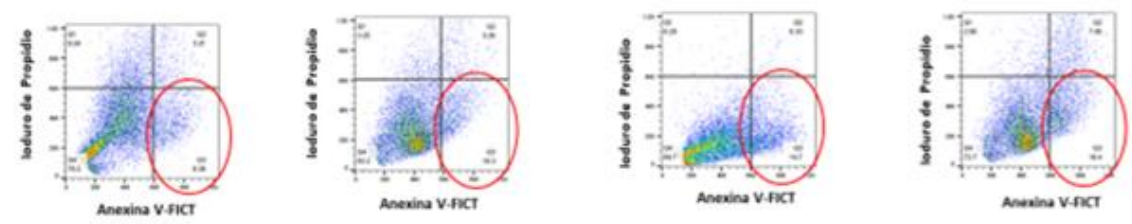
Figura 7: Citometría de flujo de cultivos celulares (RK-13) infectados con distintas cepas del VAE, a diferentes tiempos pi y controles. En el Panel A se muestran los resultados obtenidos en las células RK-13; en el Panel B se encuentran los resultados de los cultivos celulares Vero, mientras que en el Panel C se señalan los datos de las células BHK-21. Los gráficos de citometría muestran una clara diferencia en la capacidad de las distintas cepas virales para inducir apoptosis celular en diferentes sustratos celulares.

Con el objetivo de visualizar en conjunto los datos de los gráficos de citometría se realizaron diagramas donde se encuentra la información del porcentaje celular en apoptosis temprana (cuadrante Q3) en todas muestras. Se decidió mostrar en el diagrama solo la información correspondiente a la apoptosis temprana, dado a la imprecisión que representaría considerar también el cuadrante Q2, que corresponde tanto a células apoptóticas tardías como necróticas. En la Figura 8 se observan los datos arrojados por la citometría en forma fácilmente comparable, resaltándose el máximo porcentaje de apoptosis obtenido para cada línea celular.

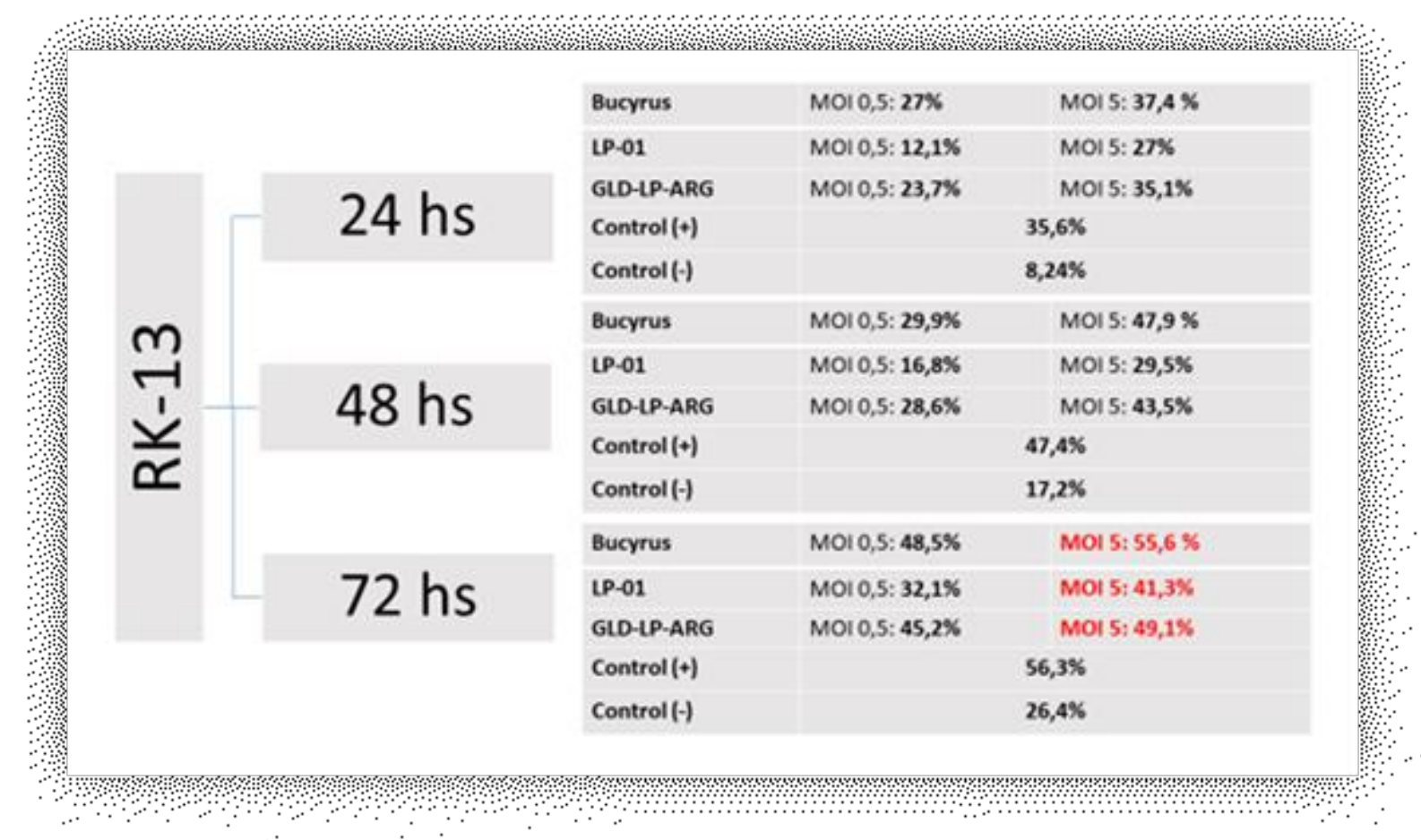



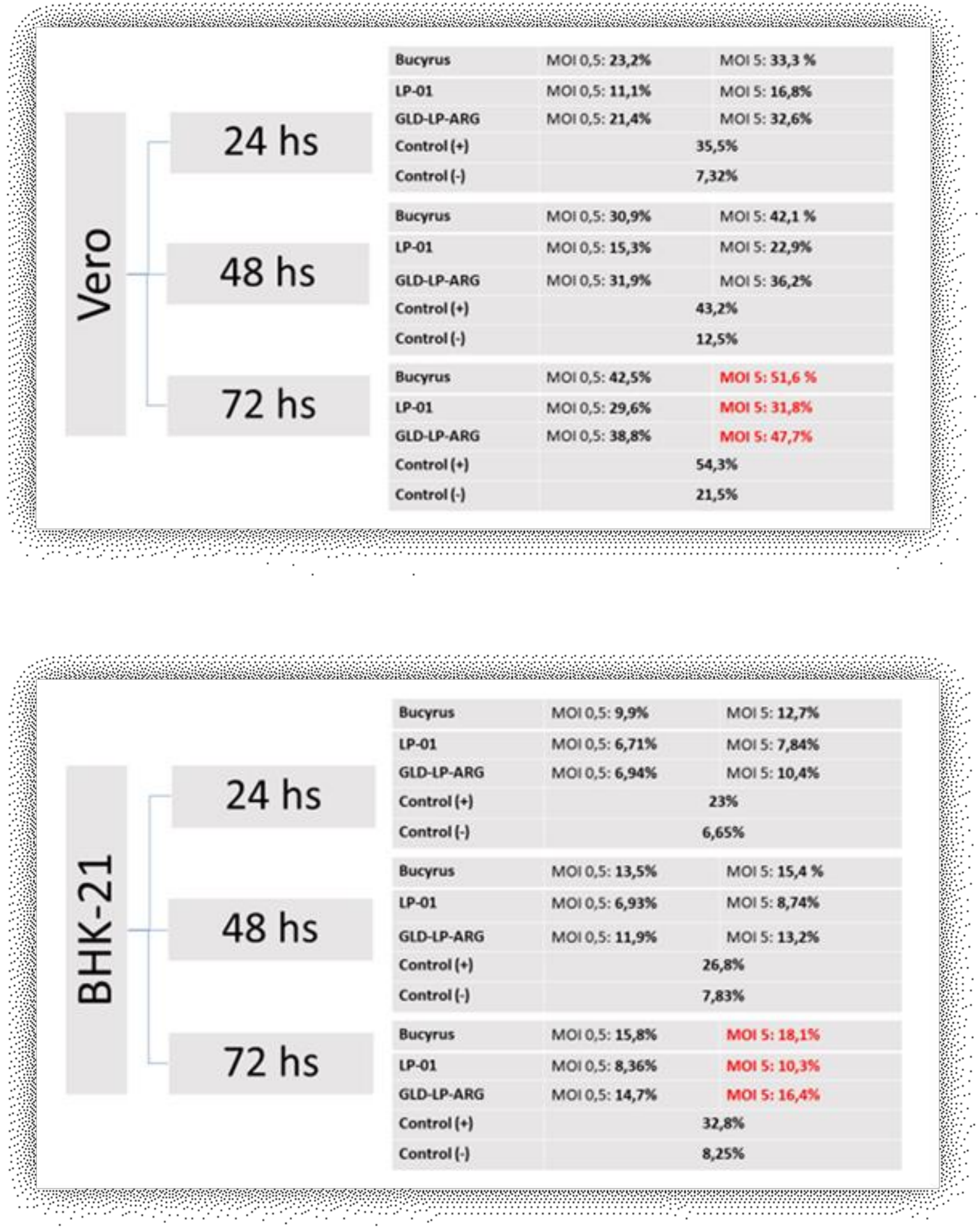
Figura 8: Diagramas con los valores de citometría de cultivos celulares infectados con distintas cepas del VAE, a diferentes tiempos pi y controles. Se señalan en rojo los máximos valores de apoptosis observados inducidos por cada una de las cepas virales, en cada línea celular. Estos resultados ilustran la relación directa entre patogenicidad de VAE y apoptosis observada. También se evidencia una relación directa entre la MOI utilizada y efecto apoptótico observado, en todos los casos. Por ultimo se manifiesta un grado más notable de apoptosis a medida que transcurren las hpi.

Los gráficos de citometría muestran una clara diferencia en la capacidad de las distintas cepas virales para inducir apoptosis celular. Analizando los máximos valores de apoptosis inducida por las cepas del VAE (observados en RK-13), encontramos un mayor efecto proapoptótico en la cepa Bucyrus (cepa patogénica americana: 55,6\% en RK-13, 72 hpi), seguido por GLD-LP-ARG (cepa patógena europea: 49,1\% en RK-13, 72 hpi), y por último se continua observando el menor efecto inductor en la cepa LP-01 (cepa no patógena europea: 41,2\% en RK-13, 72 hpi). Estos resultados ilustran la relación directa entre patogenicidad de VAE y apoptosis observada en las líneas celulares evaluadas.

Con respecto al efecto de la $\mathrm{MOI}$ en el porcentaje de células apoptóticas, los gráficos de este capítulo evidencian una relación directa entre la MOI utilizada y efecto apoptótico observado, en todos los casos.

En las infecciones con las tres cepas virales se evaluaron cuantitavamente los cambios morfológicos asociados a la apoptosis a los mismos tiempos pi evaluados con la tinción $\mathrm{NA} / \mathrm{BE}$, concluyendo que un grado más notable de apoptosis fue observado a medida que transcurrían las hpi.

Apreciamos un patrón de apoptosis distintivo en RK-13, siendo la línea que desde tiempos tempranos postinfección manifiesta cambios morfológicos asociados a apoptosis, comparado con Vero y con BHK-21, donde el tiempo en que se presenta la apoptosis parecería estar retrasado. Si bien originalmente sugerimos la posibilidad de utilizar las tres 
líneas celulares para transfectar con las construcciones recombinantes del próximo objetivo, por una cuestión de costos y tiempo y considerando los resultados de citometría, decidimos utilizar la línea RK-13 para transfectar las construcciones recombinantes. 


\section{Capítulo 2: Apoptosis observada en cultivos}

transfectados con construcciones

recombinantes del

\section{VAE}
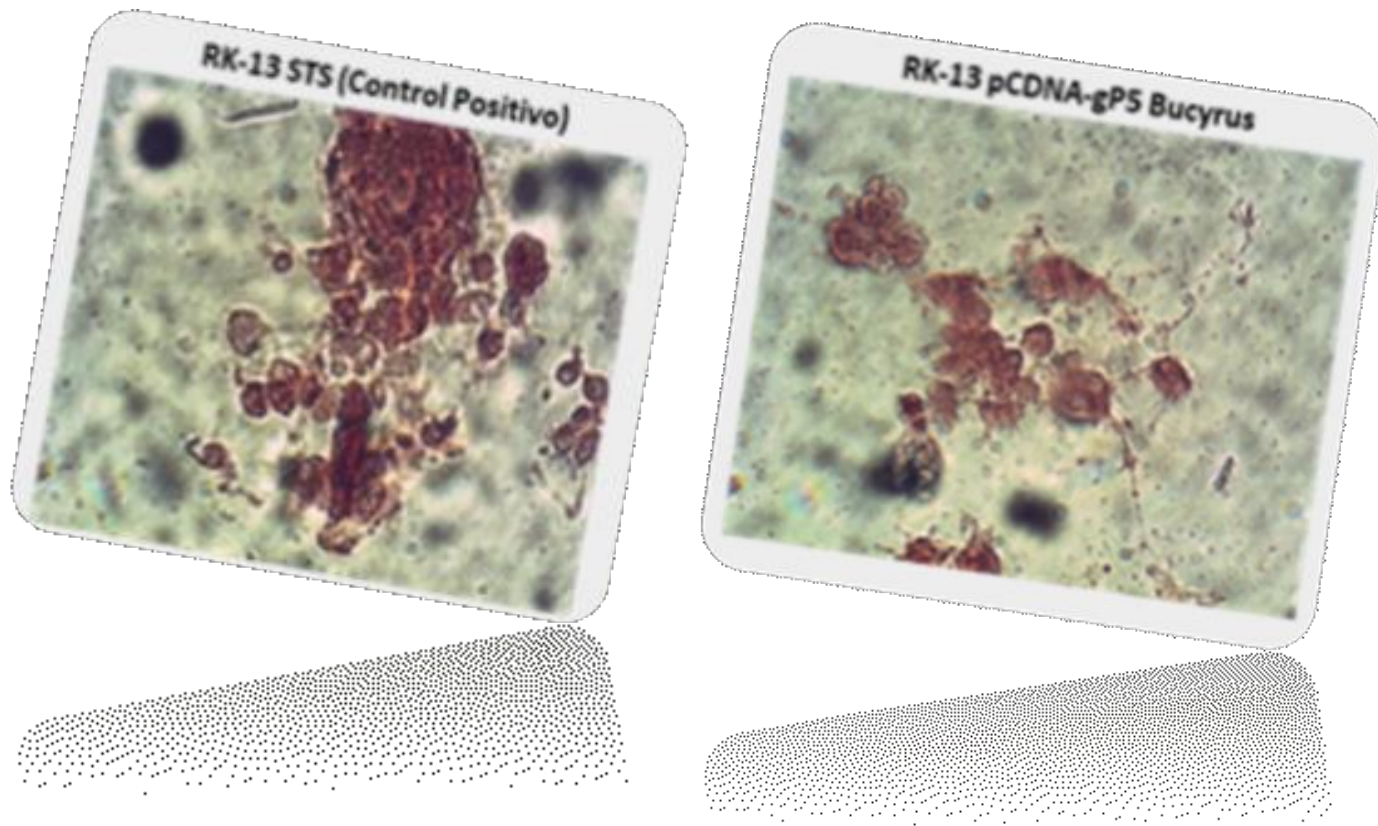
1 Extracción del ARN viral y obtención de los ADNc

2 Reacción de PCR con los cebadores específicos

3 Purificación y cuantificación de los productos de PCR

4 Subclonado de los genes en pGEM T-easy: extracción de ADN plasmídico

5 Digestión enzimática de los vectores de clonado: purificación y cuantificación de los productos digeridos

6 Ligación de los genes de interés al vector de expresión pCDNA 3.1(+)

7 Transfección con Lipofectamina 2000:

- Análisis de la expresión en geles de poliacrilamida

- Análisis de la expresión por Western blot

- Análisis de la transcripción de los ARNs mensajeros de los genes clonados

8 Detección de apoptosis por fragmentación del ADN

9 Detección de apoptosis por tinción diferencial (NA/BE)

10 Detección de apoptosis por citometría de flujo

11 Detección de caspasas-3,-8 y-9 in situ por inmunotinción 


\section{Extracción del ARN viral}

Para la obtención de los distintos ARN virales del VAE se infectaron monocapas de células RK-13 con inóculos de cada una de las cepas virales anteriormente nombradas. Los cultivos celulares fueron evaluados diariamente hasta observar el ECP característico de la infección: la lisis celular.

La extracción del ARN viral se realizó por el método de extracción fenólica con Trizol (Invitrogen). Los ADNc se sintetizaron a partir del ARN total obtenido mediante transcripción reversa, como se explicó en la sección 2 de Materiales y Métodos (M\&M). Para corroborar la correcta retrotranscripción se realizó una PCR, utilizando los cebadores correspondientes para una región interna conservada de la proteína N. Los reactivos utilizados se detallan en la Tabla 2 de M\&M, mientras que las temperaturas y tiempos utilizados fueron los mismos que se detallan en la Tabla 3 de M\&M, con excepción de la temperatura de hibridación que en este caso particular fue de 60 ㄷ. La Figura 9 muestra las bandas esperadas de aproximadamente $333 \mathrm{pb}$ en todos los casos. 


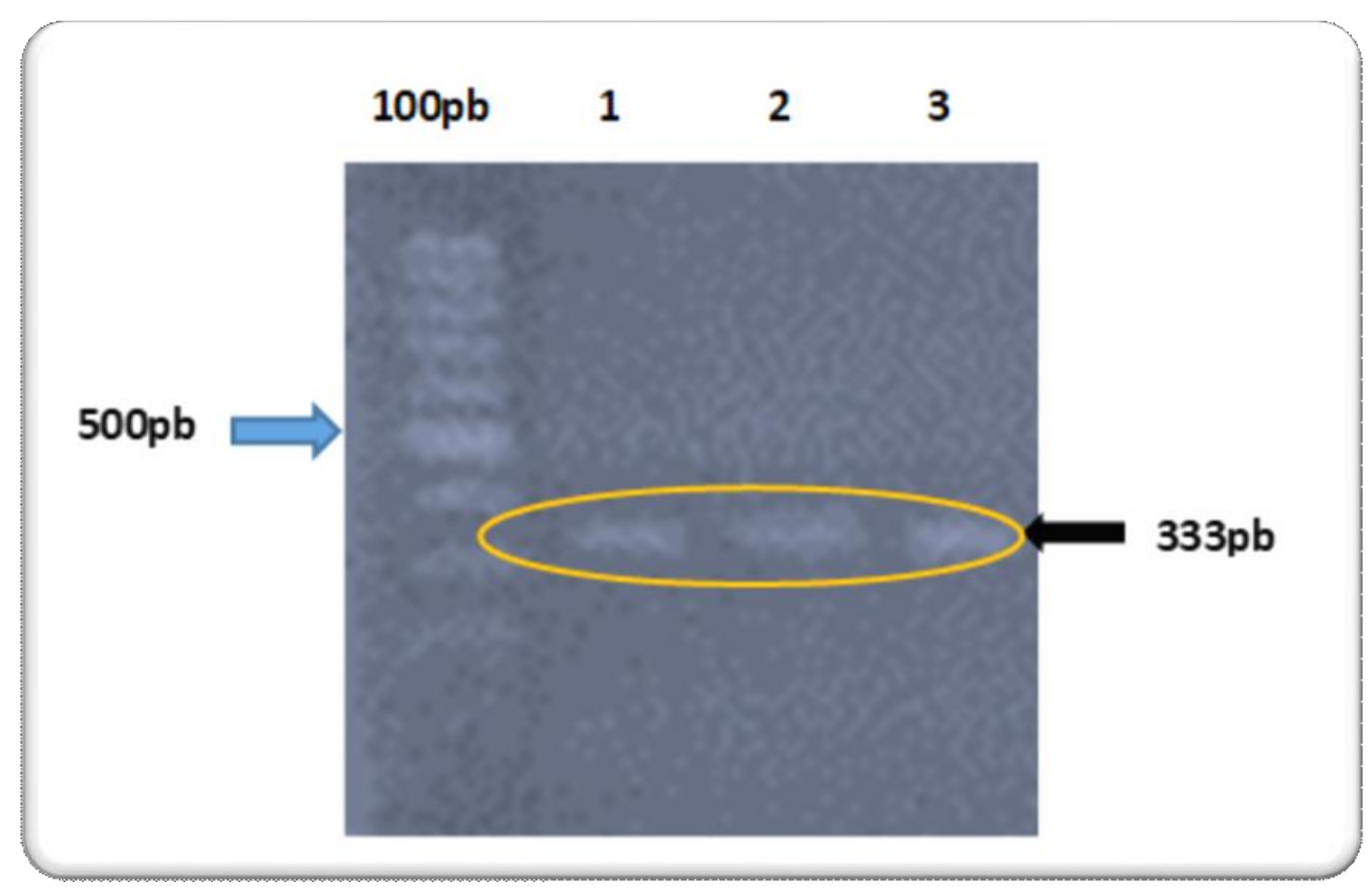

Figura 9: PCR con cebadores diagnósticos del VAE. Se muestran las bandas esperadas de aproximadamente 333 pb en todos los casos. Este tamaño corresponde al gen de la proteína N del VAE. 1) Cepa Bucyrus. 2) Cepa LP-01. 3) Cepa GLD-LP-ARG.

\section{Reacción de PCR con los cebadores específicos}

Para llevar a cabo cada uno de los ensayos de PCR se diseñaron pares de cebadores específicos para los genes que codifican las proteínas N, M y gP5 (gen N, gen M y gen gP5). Dado que al momento del comienzo del trabajo se contaba con la secuenciación parcial de los aislamientos LP-01 y GLD-LP-ARG, los diseños de los cebadores se basaron en la secuencia de la cepa de referencia de VAE publicada en el National Center of Biotechnology Information con el número de acceso: NC 002532. Los reactivos utilizados se detallan en la Tabla 2 de $M \& M$, mientras que las temperaturas y tiempos utilizados fueron los mismos que se detallan en la Tabla 3 de M\&M. Las bandas esperadas son de 799 pb correspondiente al gen gP5 (Figura 10), 511 pb, del gen M (Figura 11) y 380 pb, del gen N (Figura 12). El gen gP5 de la cepa LP-01 no pudo levantarse con los cebadores diseñados en base al genoma de la cepa de referencia, si bien se utilizaron temperaturas y 
tiempos de PCR alternativos. Intuimos que esto ocurrió porque el gen de la proteína gP5 en la cepa LP-01 presentaría variaciones nucleotídicas en las regiones donde los cebadores debían hibridarse.

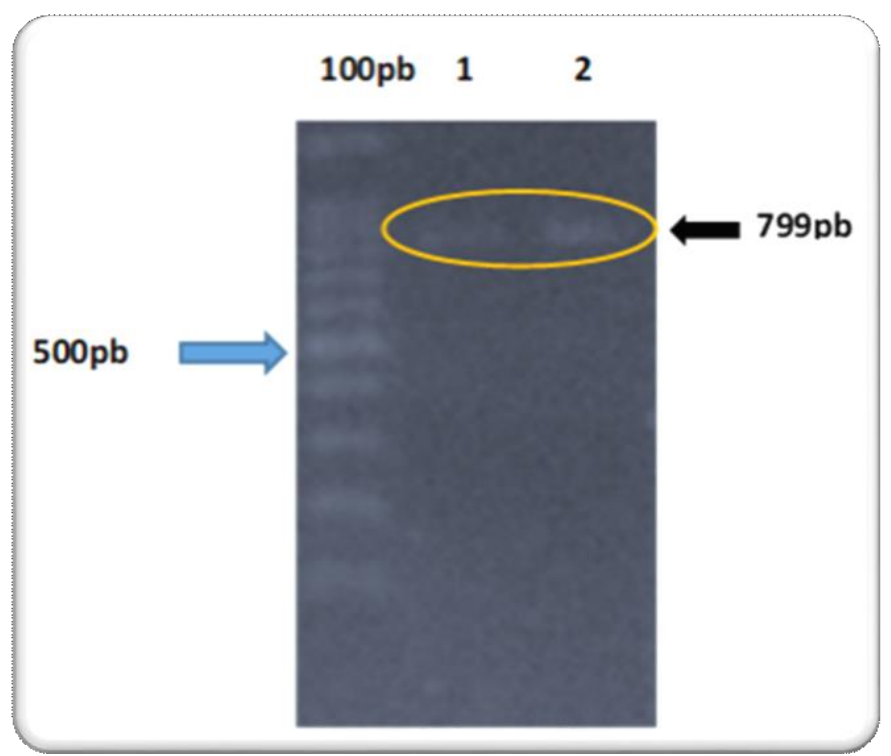

Figura 10: PCR con cebadores específicos para el gen gP5 del VAE. Se muestran las bandas esperadas de aproximadamente 799 pb. Este tamaño corresponde al gen de la proteína gP5 del VAE. En la cepa LP-01 no pudo levantarse este producto con los cebadores diseñados en base al genoma de la cepa de referencia, si bien se utilizaron temperaturas y tiempos de PCR alternativos. 1) Cepa Bucyrus. 2) Cepa GLD-LP-ARG.

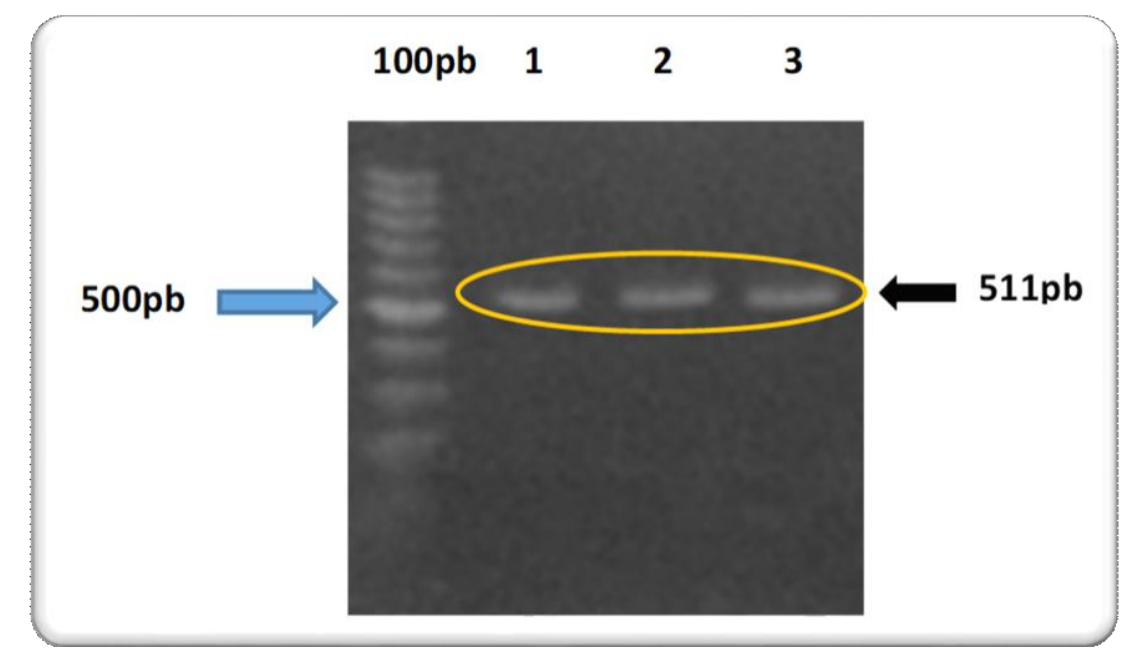

Figura 11: PCR con cebadores específicos para el gen $\mathrm{M}$ del VAE. Se muestran las bandas esperadas de aproximadamente $511 \mathrm{pb}$ en todos los casos. Este tamaño corresponde al gen de la proteína M del VAE. 1) Cepa Bucyrus. 2) Cepa LP-01. 3) Cepa GLD-LPARG. 


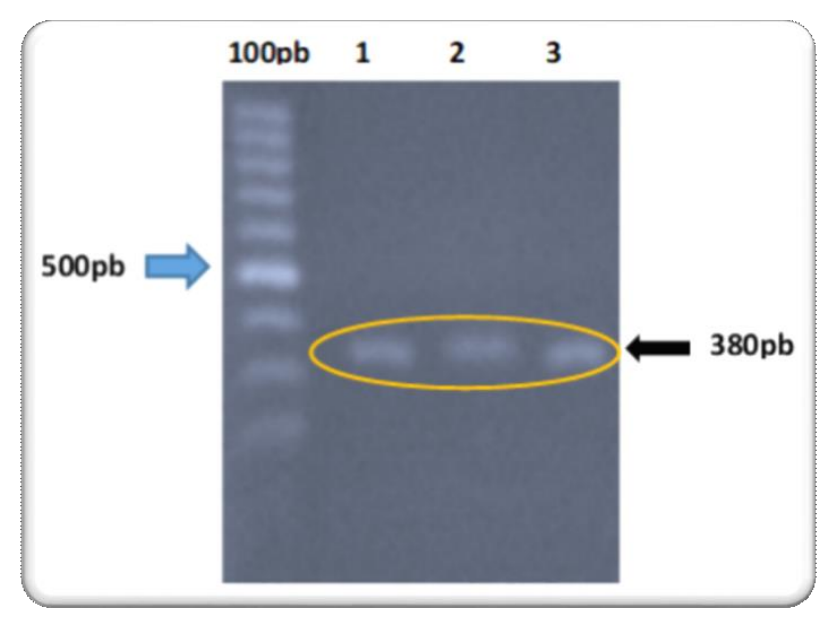

Figura 12: PCR con cebadores específicos para el gen $\mathbf{N}$ del VAE. Se muestran las bandas esperadas de aproximadamente $380 \mathrm{pb}$ en todos los casos. Este tamaño corresponde al gen de la proteína N del VAE. 1) Cepa Bucyrus. 2) Cepa LP-01. 3) Cepa GLD-LPARG.

\section{Purificación y cuantificación de los productos de PCR}

La purificación de los fragmentos amplificados por PCR se realizó empleando el kit comercial Wizard SV Gel and PCR Clean-Up System (Promega), siguiendo el protocolo allí suministrado. También se utilizó el método de purificación por precipitación por polietilenglicol (PEG). Los detalles del proceso se encuentran en la sección 5 de M\&M.

Los productos purificados fueron cuantificados en geles de agarosa empleando el MassRulerTM DNA Ladder, low range, ready-to-use (Fermentas) como patrón de referencia.

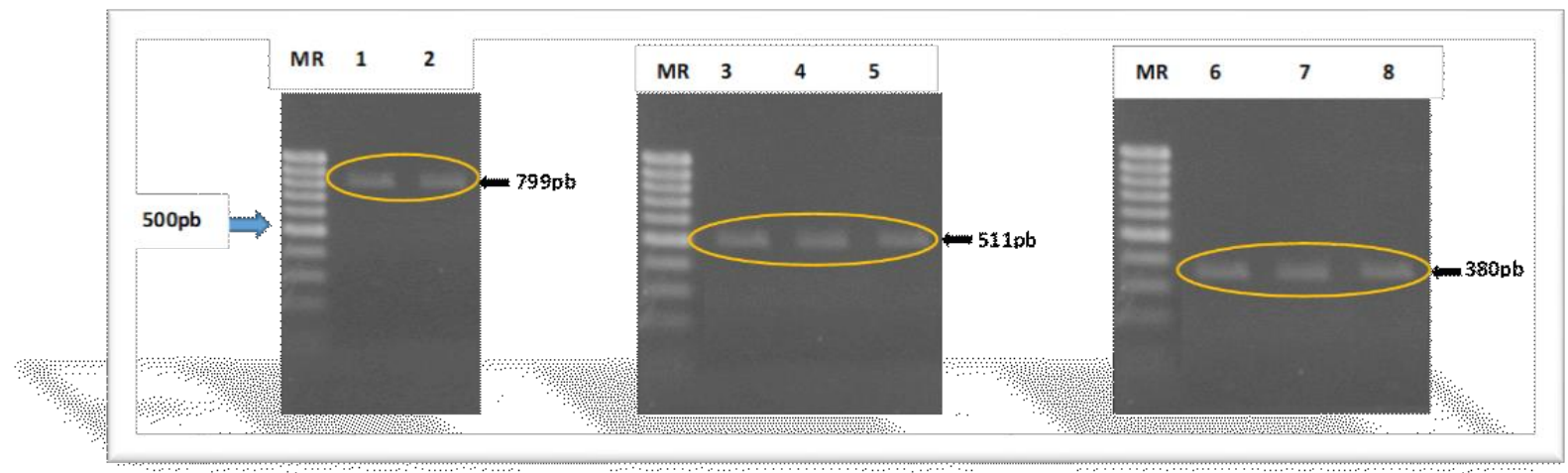


Figura 13: PCR purificadas de los genes gP5, $\mathrm{M}$ y $\mathbf{N}$ de las cepas del VAE. Los productos purificados fueron cuantificados en geles de agarosa, donde se estimó visualmente una concentración en todos los casos de $10 \mathrm{ng} / \mu \mathrm{l}$, luego de comparar las bandas obtenidas con el patrón de referencia. MR: Mass Ruler. 1) gP5 Bucyrus. 2) gP5 GLD-LP-ARG. 3) M Bucyrus. 4) M LP-01. 5) M GLDLP-ARG. 6) N Bucyrus. 7) N LP-01. 8) N GLD-LP-ARG.

Comparando la intensidad de las bandas obtenidas con el patrón de referencia, estimamos tener una concentración de producto purificado de $10 \mathrm{ng} / \mu \mathrm{l}$, en todos los casos.

\section{Subclonado de los genes en pGEM T-easy. Extracción de ADN plasmídico}

Los productos de PCR fueron subclonados al vector de clonado pGEM-T Easy Vector Systems (Promega) siguiendo el manual de procedimiento del fabricante y las condiciones detalladas en el apartado 6 de M\&M. Previo a la transformación, la correcta ligación de los insertos al vector de clonado se corroboró a través de la técnica de PCR con los cebadores M13 Forward y Reverse. Las reactivos, temperaturas y tiempos utilizados corresponden a aquellos de las Tablas 2 y 3 de M\&M, con excepción de la temperatura de hibridación que fue de 55 ำ. La obtención de un producto de 251 pb indica la presencia de vector no ligado, mientras que 251 pb más el tamaño del inserto, indica la correcta ligación del inserto al vector. La banda esperada de PCR tras la correcta ligación de cada producto de PCR purificado con el vector pGEM T-easy es: 1050 pb para las construcciones pGEM-gP5; 760 pb para las tipo pGEM-M y 620 pb para las construcciones pGEM-N. En la Figura 13 se observan las bandas esperadas. 


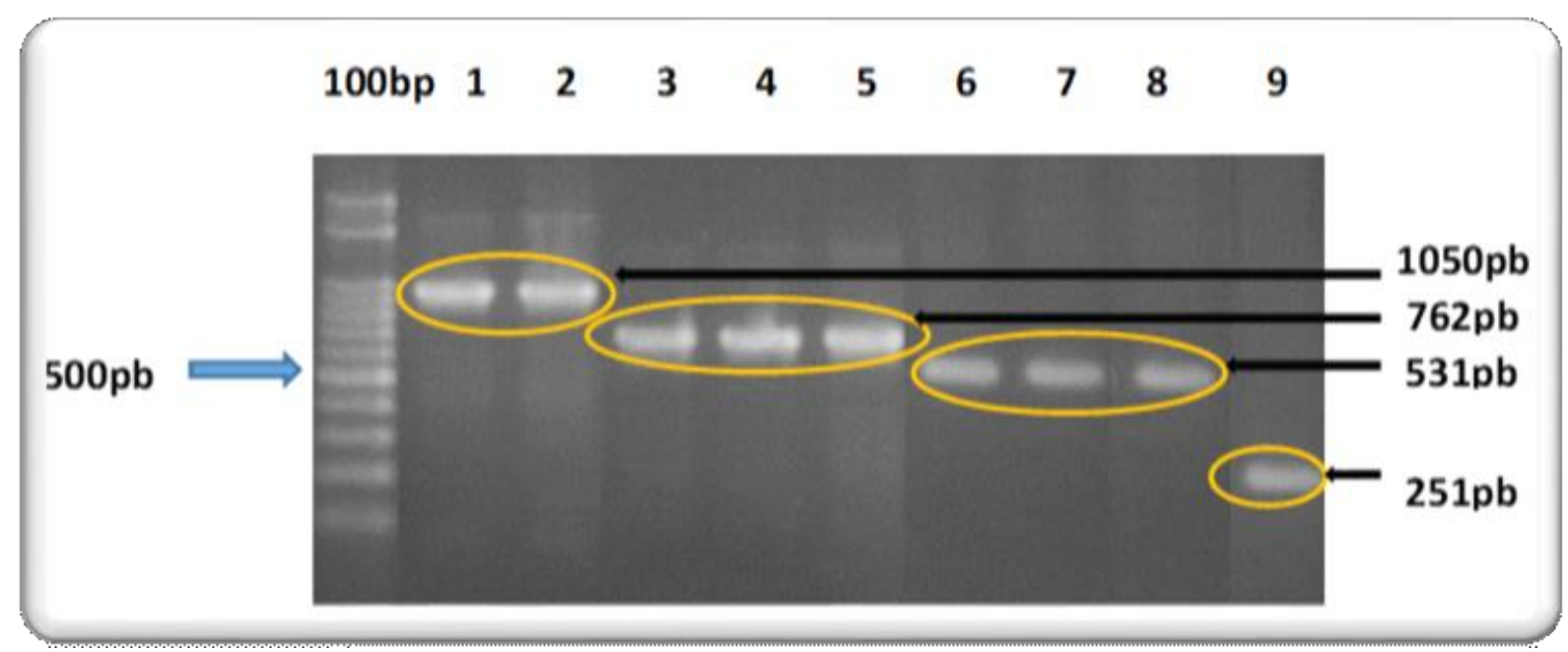

Figura 14: PCR con cebadores M13 del vector pGEM-inserto especifico de los genes $\mathbf{g P 5}, \mathbf{M}$ y $\mathbf{N}$ de las cepas del VAE. La obtención de un producto de $251 \mathrm{pb}$ indica la presencia de vector no ligado, mientras que $251 \mathrm{pb}$ más el tamaño del inserto, indica la correcta ligación del inserto al vector. La banda esperada es igual a 1050 pb para las construcciones pGEM-gP5; 760 pb para las tipo pGEM-M y 620 pb para las construcciones pGEM-N. 1) Producto PCR pGEM-gP5 Bucyrus. 2) Producto PCR pGEM-gP5 GLD-LP-ARG. 3) Producto PCR pGEM-M Bucyrus. 4) Producto PCR pGEM-M LP-01. 5) Producto PCR pGEM-M GLD-LP-ARG. 6) Producto PCR pGEM-N Bucyrus. 7) Producto PCR pGEM-N LP-01. 8) Producto PCR pGEM-N GLD-LP-ARG. 9) Producto PCR pGEM (vector vacío)

Una vez corroborada la correcta ligación del gen de interés al vector de clonado pGEM-T Easy, se realizó la competencia y transformación de las bacterias E. coli JM109, como indica el apartado 6 de M\&M.

Para la extracción del ADN plasmídico se procedió como indica el apartado 7 de M\&M. En la Figura 15 se observan las extracciones de ADN plasmídico (minipreps) vector pGEMinserto específico de los genes gP5, M y $\mathrm{N}$ de las cepas del VAE obtenidos tras la transformación bacteriana. 


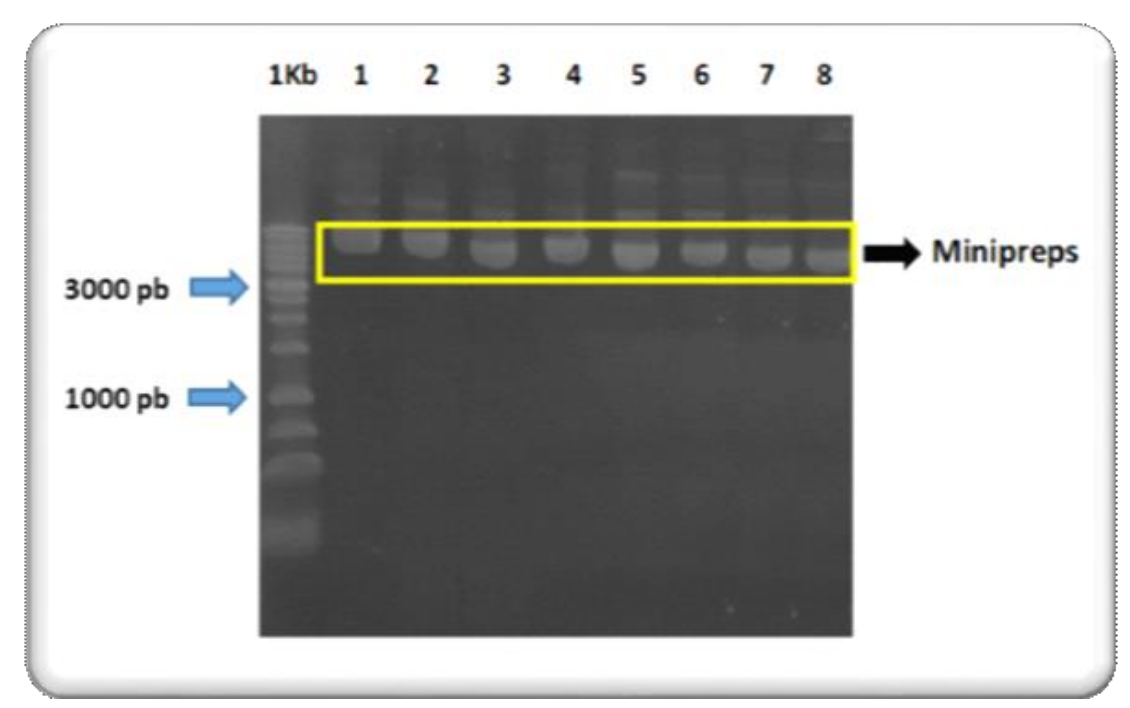

Figura 15: Minipreps del vector pGEM-ligando específico de los genes gP5, $\mathbf{M}$ y $\mathbf{N}$ de las cepas del VAE. Se observan las extracciones de ADN plasmídico (minipreps) de las construcciones vector pGEM-inserto específico de los genes gP5, M y N de las cepas del VAE obtenidos tras la transformación bacteriana en bacterias E.coli JM109. 1) pGEM-gP5 Bucyrus. 2) pGEM-gP5 GLDLP-ARG. 3) pGEM-M Bucyrus. 4) pGEM-M LP-01. 5) pGEM-M GLD-LP-ARG. 6) pGEM-N Bucyrus. 7) pGEM-N LP-01. 8) pGEM-N GLD-LP-ARG.

5 Digestión enzimática de los vectores de clonado: purificación y cuantificación de los productos digeridos

Para las digestiones de cada una de las construcciones fueron utilizadas las siguientes enzimas de restricción y buffers acorde a las mejores eficiencias de digestión: para pGEMgP5: BamHI/ HindIII y buffer E; para pGEM-M: BamHI/Xhol y buffer B y para pGEM-N: BamHI/Xhol y buffer B. Los detalles del proceso se encuentran en el apartado 8 de M\&M. Los tamaños esperados corresponden a casa uno de los genes específicos: 799 pb (gen gP5), 511 pb (gen M) y 380 (gen N). En la Figura 16 se observan los productos digeridos purificados para ser clonados en el vector de expresión pCDNA 3.1(+). 


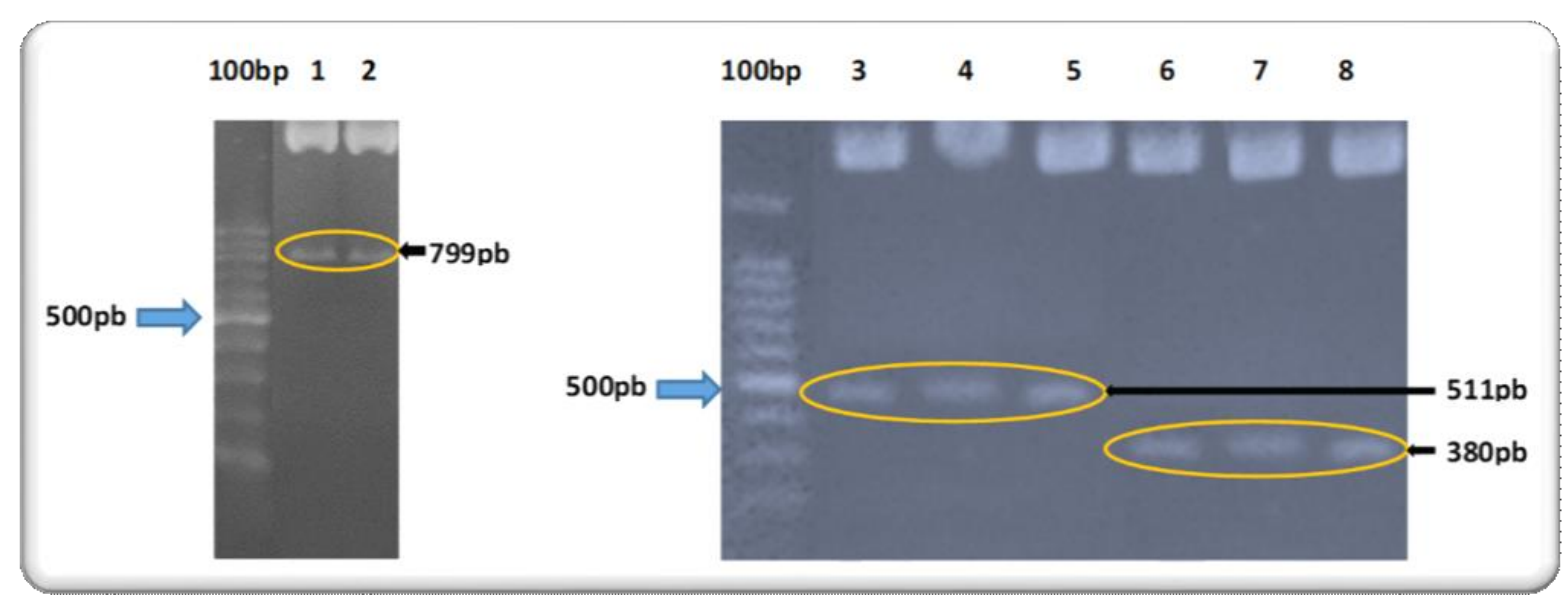

Figura 16: Digestiones del vector pGEM-ligando específico de los genes gP5, $\mathbf{M}$ y $\mathbf{N}$ de las cepas del VAE. Se observa la obtención de las bandas esperadas: 799 pb para los genes gP5 (digestión con BamHI/ HindIII y buffer E); 511 pb para los genes M (digestión con BamHI/Xhol y buffer B) y bandas de 380 pb correspondientes a los genes N (digestión con BamHI/Xhol y buffer B).

1) Digestión pGEM-gP5 Bucyrus. 2) Digestión pGEM-gP5 GLD-LP-ARG. 3) Digestión pGEM-M Bucyrus. 4) Digestión pGEM-M LP-01.

5) Digestión pGEM-M GLD-LP-ARG. 6) Digestión pGEM-N Bucyrus. 7) Digestión pGEM-N LP-01. 8) Digestión pGEM-N GLD-LP-ARG.

\section{Ligación de los genes de interés al vector de expresión pCDNA 3.1(+)}

Para todas las reacciones de ligación se utilizó el protocolo descripto en la sección 10 de

M\&M. La eficiencia de las reacciones de ligación al vector de expresión pCDNA 3.1(+) fue evaluada por PCR utilizando el par de cebadores PCDNA Forward y Reverse. Las reactivos, temperaturas y tiempos utilizados corresponden a aquellos de las Tablas 2 y 3 de M\&M, con excepción de la temperatura de hibridación que fue de $48^{\circ} \mathrm{C}$. La obtención de un producto de $177 \mathrm{pb}$ indica la presencia de vector no ligado, mientras que $177 \mathrm{pb}$ más el tamaño del inserto, indica la correcta ligación del inserto al vector. La banda esperada de PCR tras la correcta ligación de cada producto de PCR purificado con el vector pCDNA es: $976 \mathrm{pb}$ para las construcciones pcDNA-gP5; $688 \mathrm{pb}$ para las tipo pCDNA-M y $557 \mathrm{pb}$ para las construcciones pCDNA-N. En la Figura 17 se observan las bandas esperadas. 


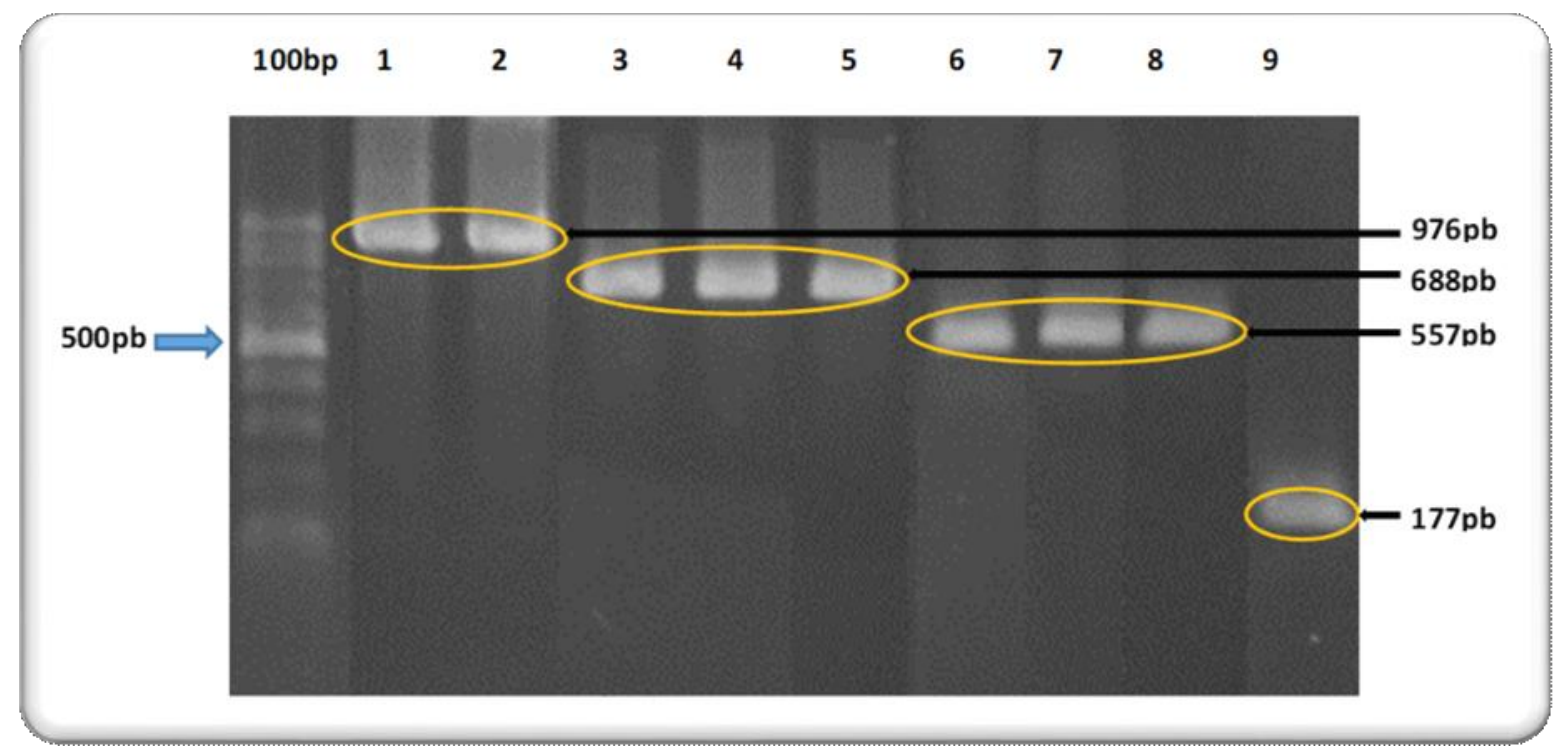

Figura 17: PCR con cebadores pCDNA del vector pCDNA-inserto especifico de los genes gP5, $M$ y $\mathbf{N}$ de las cepas del VAE. Se observa la obtención de las bandas esperadas de PCR, debido a la correcta ligación de los insertos con el vector pCDNA: 976 pb para las construcciones pcDNA-gP5; 688 pb para las tipo pCDNA-M y 557 pb para las construcciones pCDNA-N. 1) Producto PCR pCDNA-gP5 Bucyrus. 2) Producto PCR pCDNA-gP5 GLD-LP-ARG. 3) Producto PCR pCDNA-M Bucyrus. 4) Producto PCR pCDNA-M LP-01. 5) Producto PCR pCDNA-M GLD-LP-ARG. 6) Producto PCR pCDNA-N Bucyrus. 7) Producto PCR pCDNA-N LP-01. 8) Producto PCR pCDNA-N GLD-LP-ARG. 9) Producto PCR pCDNA (vector vacío).

En las transformaciones con el vector pCDNA 3.1(+), se empleó la cepa E.coli JM109. Se seleccionaron colonias al azar a las que se les extrajo el ADN plasmídico, como se observa en la Figura 18. Los detalles del proceso se encuentran en la sección 10 de M\&M.

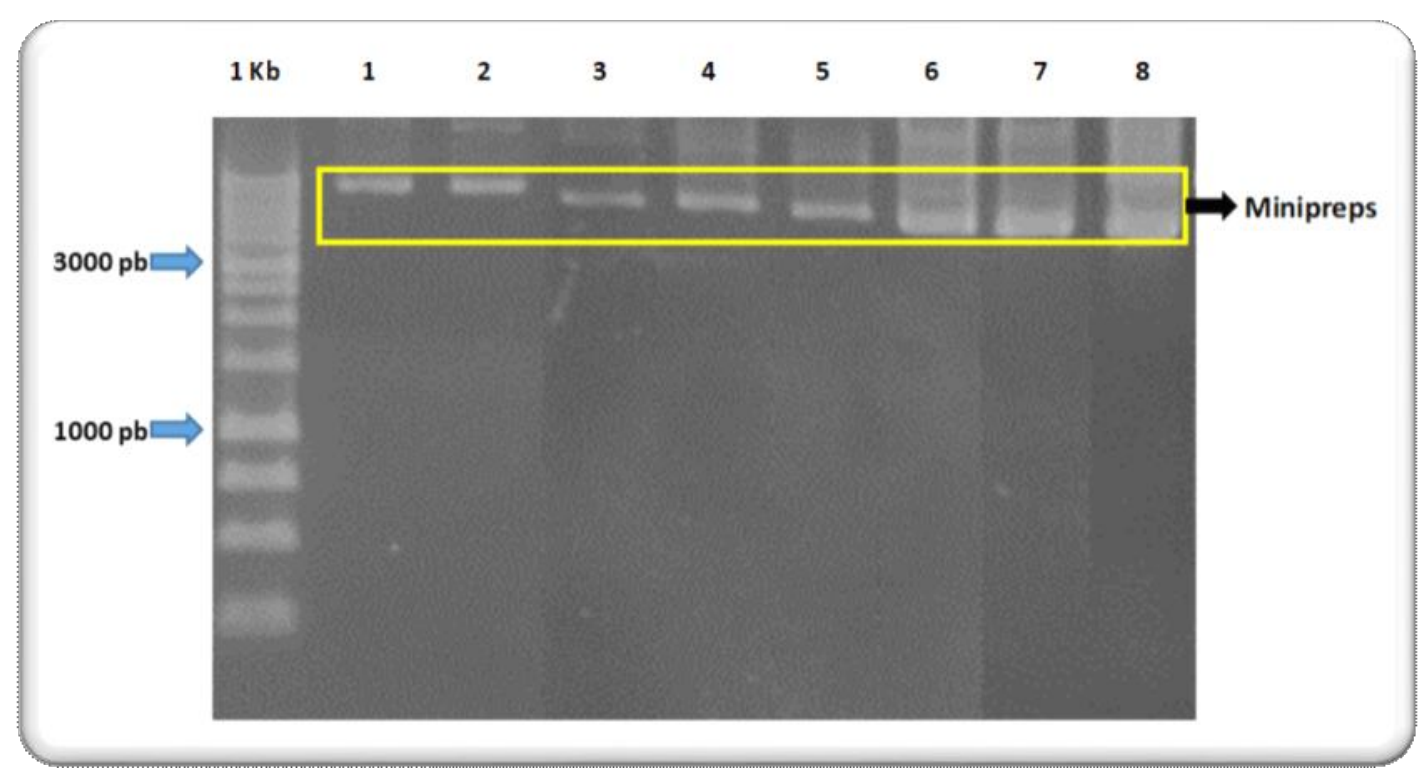


Figura 18: Minipreps del vector pCDNA-ligando específico de los genes $\mathbf{g P 5}, \mathbf{M}$ y $\mathbf{N}$ de las cepas del VAE. Se observan los ADN plasmídicos extraídos de las colonias seleccionadas al azar, luego de las transformaciones con el vector pCDNA 3.1(+) en bacterias E.coli JM109. 1) pCDNA-gP5 Bucyrus. 2) pCDNA-gP5 GLD-LP-ARG. 3) pCDNA-M Bucyrus. 4) pCDNA-M LP-01. 5) pCDNA-M GLD-LPARG. 6) pCDNA-N Bucyrus. 7) pCDNA-N LP-01. 8) pCDNA-N GLD-LP-ARG.

La presencia de los genes de interés fue confirmada por PCR con cebadores PCDNA como

se explicó anteriormente. La obtención de las bandas esperadas se observa en la Figura

19. Las colonias positivas se almacenaron en glicerol stock.

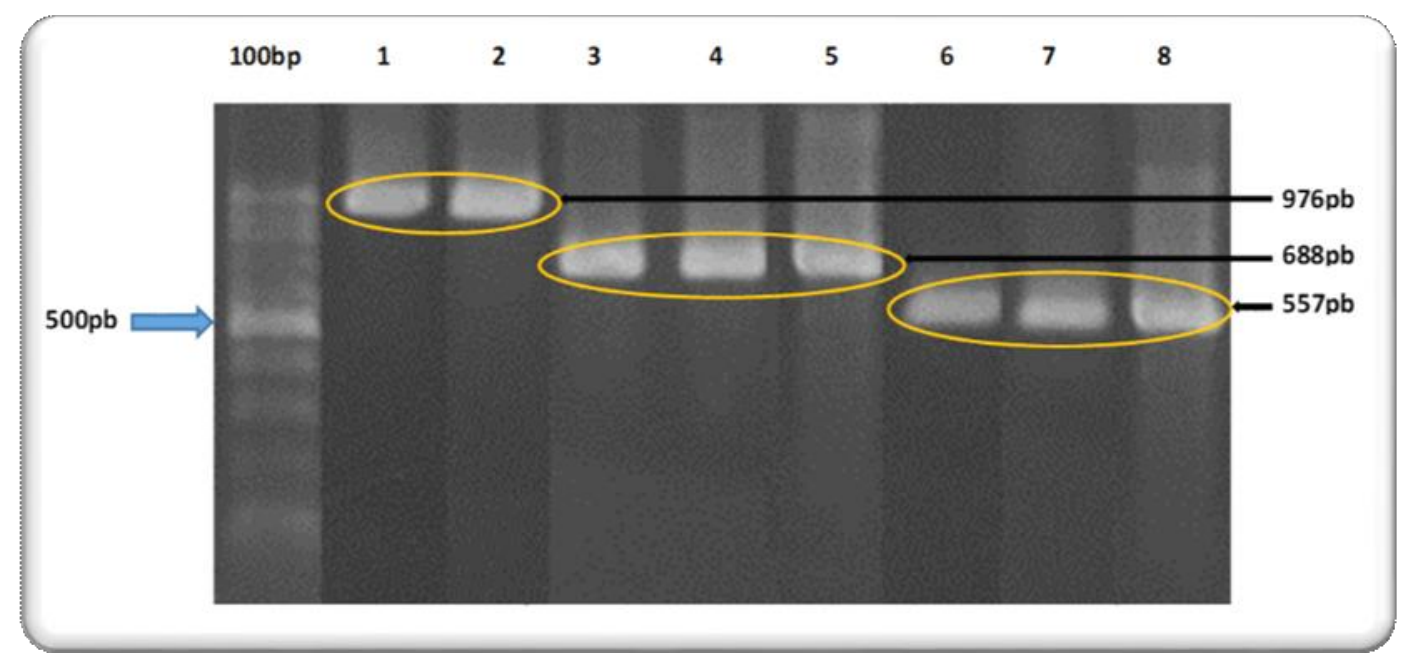

Figura 19: PCR con cebadores pCDNA del vector pCDNA-inserto específico de los genes gP5, M y N de las cepas del VAE. Se observa la obtención de las bandas esperadas: 976 pb para las construcciones portando el gen gP5; 688 en el caso de las construcciones con el gen $\mathrm{M}$ y 557 pb para las construcciones portando el gen N. 1) Producto PCR pCDNA-gP5 Bucyrus. 2) Producto PCR pCDNA-gP5 GLD-LP-ARG. 3) Producto PCR pCDNA-M Bucyrus. 4) Producto PCR pCDNA-M LP-01. 5) Producto PCR pCDNA-M GLD-LP-ARG. 6) Producto PCR pCDNA-N Bucyrus. 7) Producto PCR pCDNA-N LP-01. 8) Producto PCR pCDNA-N GLD-LPARG.

\section{Transfección con Lipofectamina 2000:}

En la Figura 20 se observan cultivos de la línea celular RK-13 sometidos a concentraciones crecientes de geneticina, durante una semana. Este antibiótico tiene una vida media de 72 hs, por lo tanto los medios de cultivo fueron renovados cada tres días. En el panel A de la

Figura 20 la concentración de geneticina del medio de cultivo fue de 0,001 mg/ml, en 
20.B: $0,0025 \mathrm{mg} / \mathrm{ml}$, en 20.C: $0,005 \mathrm{mg} / \mathrm{ml}$ y en $20 . \mathrm{D}$ fue de $0,01 \mathrm{mg} / \mathrm{ml}$. Esta última fue la dosis seleccionada, debido a que se produjo la total mortandad de las células RK-13 durante el transcurso de la segunda semana de selección.

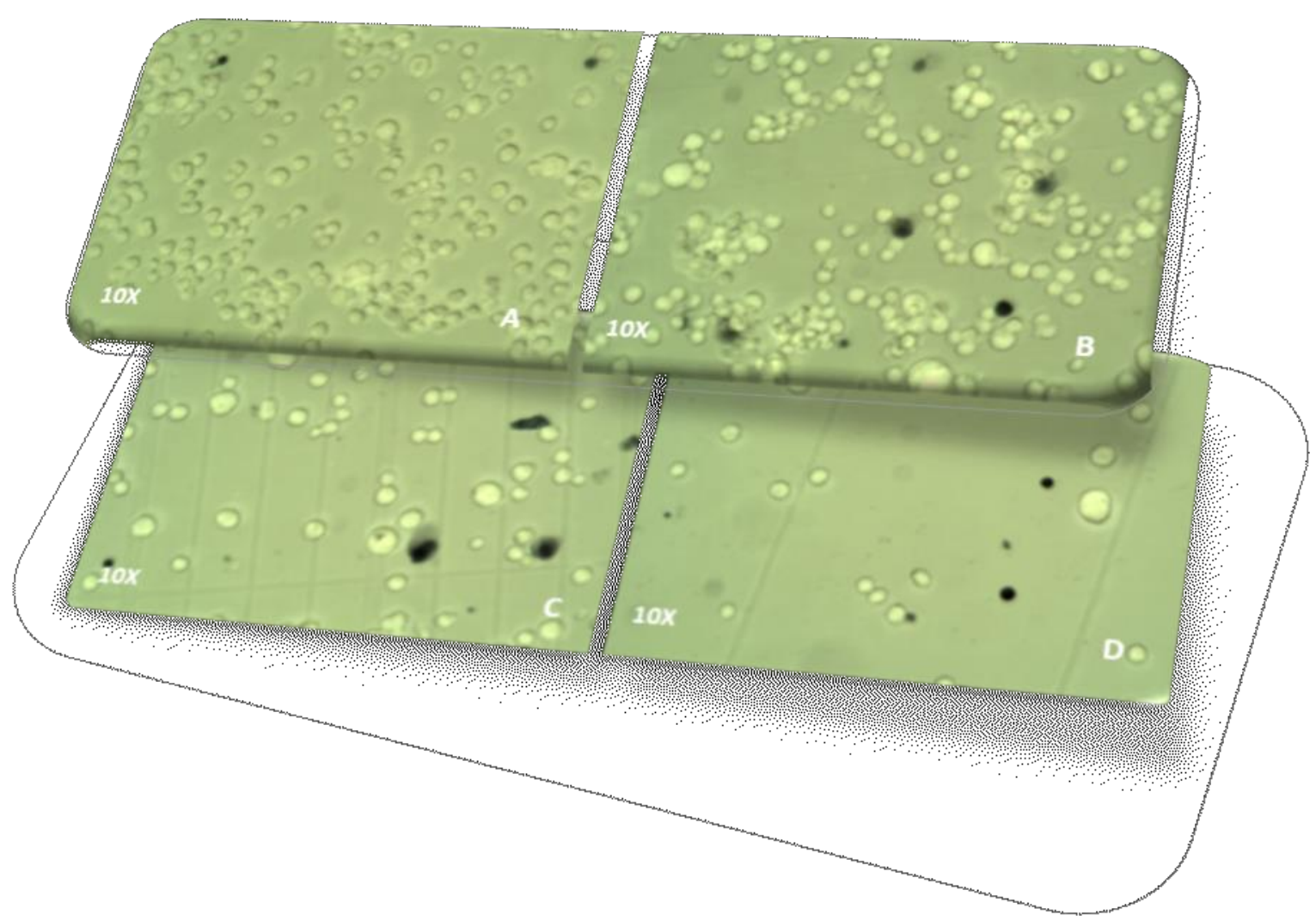

Figura 20: Identificación de las concentraciones de geneticina citotóxicas para células RK-13. Se observan cultivos de la línea celular RK-13 sometidos a concentraciones crecientes de geneticina. La dosis seleccionada fue $0,01 \mathrm{mg} / \mathrm{ml}$, debido a que se produjo la total mortandad de las células RK-13 durante el transcurso de la segunda semana de selección. A) 0,001 mg/ml. B) $0,0025 \mathrm{mg} / \mathrm{ml}$. C) $0,005 \mathrm{mg} / \mathrm{ml}$. D) $0,01 \mathrm{mg} / \mathrm{ml}$.

\section{- Análisis de la expresión en geles de poliacrilamida}

Los PM esperados de cada proteína son los siguientes: N (12 kDa), M (20 kDa) y gP5 (30-45 $\mathrm{kDa}$ ). Se utilizaron geles de poliacrilamida de $12,5 \%$ y las muestras fueron procesadas según lo detallado en el apartado 12 de M\&M. Con esta técnica solo pudimos distinguir bandas proteicas de acuerdo al PM de dos construcciones recombinantes: la proteína $\mathrm{N}$ de 
Bucyrus y de GLAD-LP-ARG, las cuales se observan dentro de un círculo negro en la Figura

21.

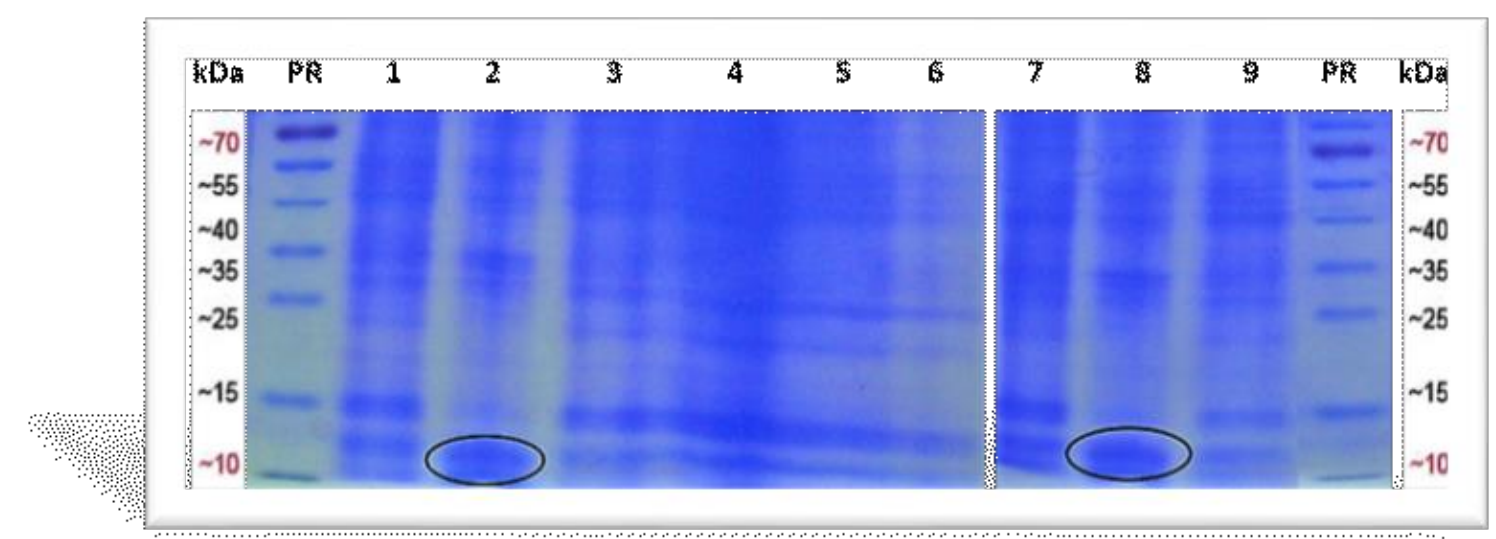

Figura 21: Análisis de la expresión de las construcciones recombinantes en geles de poliacrilamida. Con esta técnica solo pudimos distinguir dos bandas proteícas, de $42 \mathrm{kDa}$, compatibles con las construcciones recombinantes $\mathrm{N}$ de Bucyrus y N de GLAD-LP-ARG, las cuales se observan dentro de un círculo negro. Todas las muestras corresponden a cultivos RK-13 transfectados. PR) Page Ruler. 1) RK-13-pCDNA-gP5 Bucyrus. 2) RK-13-pCDNA-M Bucyrus. 3) RK-13-pCDNA-N Bucyrus. 4) RK-13pCDNA-N LP-01. 5) RK-13-pCDNA-M LP-01. 6) RK-13-pCDNA-gP5 GLD-LP-ARG. 7) RK-13-pCDNA-M GLD-LP-ARG. 8) RK-13-pCDNAN GLD-LP-ARG. 9) RK-13-pCDNA.

\section{- Análisis de la expresión por Western blot}

Esta técnica fue realizada siguiendo los pasos detallados en el apartado 13 de M\&M.

Como Ac primario se utilizo suero policlonal equino (debido a la ausencia de AC monoclonales especificos) y como secundario un AC-anti equino marcado con peroxidasa. En la Figura 22 se observa solo la detección fehaciente de la proteína gp5 de la cepa Bucyrus con los sueros policlonales utiizados, resaltada dentro de un circulo negro, al igual que en el control positivo (muestra de celulas RK-13 infectadas con el VAE completo, cepa Bucyrus). Si bien se realizaron numerosos ensayos en busqueda de la expresión de proteínas recombinantes por WB, no obtuvimos éxito con esta técnica. Consideramos que este resultado se debe al uso como Ac primario de un Ac policlonal equino, dado que carecemos en nuestro laboratorio de Ac monoclonales especificos. La detección de la 
proteina gP5 de la cepa más virulenta de esta enfermedad no seria un hecho fortuito sino que se deberia al hecho que es la proteína más antigénica, según la bibliografia detallada en la sección Introducción.

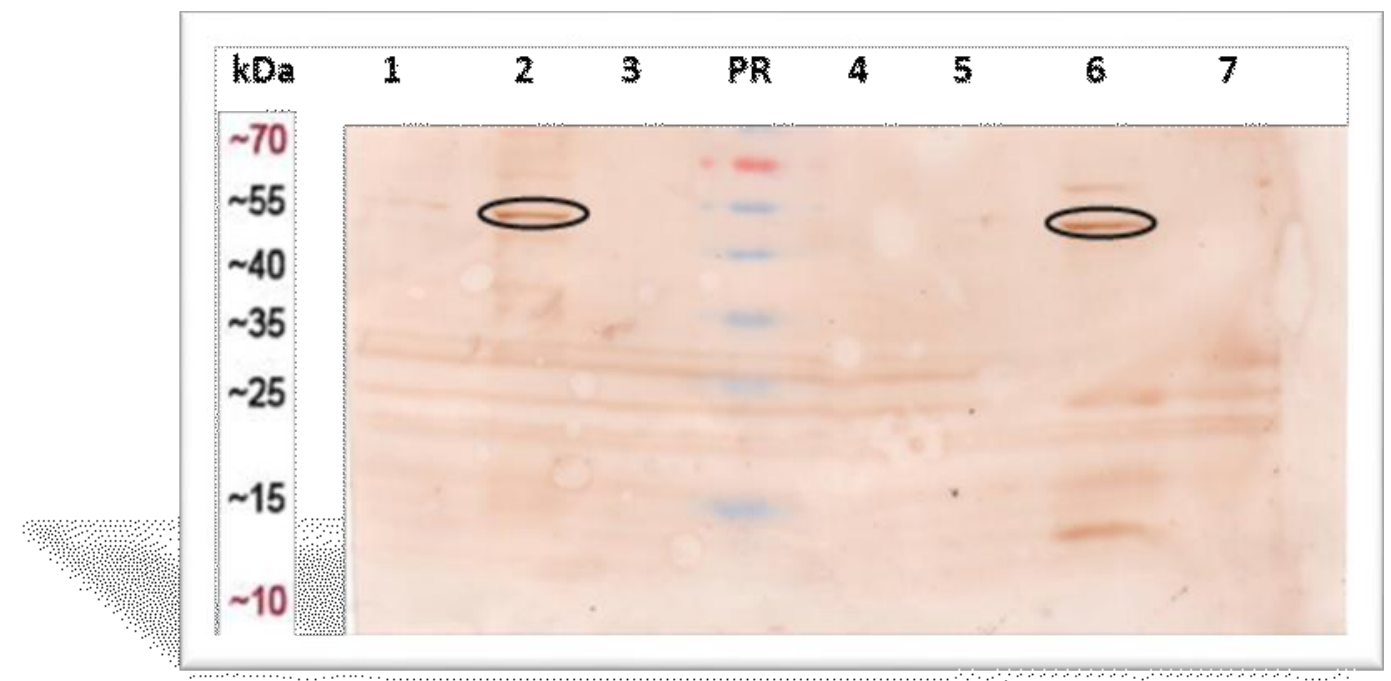

Figura 22: Análisis de la expresión de la expresión por Western blot de las construcciones recombinantes. Se observa sólo la detección de la proteína gp5 de la cepa Bucyrus, resaltada dentro de un círculo negro, al igual que en el control positivo (muestra de células RK-13 infectadas con el VAE completo, cepa Bucyrus). PR) Page Ruler. 1) RK-13-pCDNA. 2) RK-13-pCDNA-gP5 Bucyrus. 3) RK-13-pCDNA-gP5 GLD-LP-ARG. 4) RK-13-pCDNA-N LP-01. 5) RK-13-pCDNA-M LP-01. 6) RK-13-VAE Bucyrus (control positivo). 7) RK-13.

Debido a que no se detectaron todas las proteínas expresadas mediante el uso de distintos sueros positivos a AVE (policlonales del banco de sueros), tanto de animales vacunados como de infectados naturalmente, se procedió a transfectar células Vero, con el objetivo de minimizar la inespecificidad observada con los sueros utilizados. Sin embargo, utilizando células Vero transfectadas, resultó dificil poner en evidencia la expresión de las proteínas clonadas. Por esa razón se realizó el siguiente ensayo.

\section{- Análisis de la transcripción de los ARNs mensajeros de los genes clonados}


Para analizar la expresión de los genes virales en las células transfectadas, se procedió como se detalla en el apartado 14 de M\&M. El objetivo de este procedimiento fue corroborar la transcripción de los productos génicos virales en los cultivos transfectados, es decir ARNm de origen viral, dado el poco éxito de las técnicas anteriores para demostrar la expresión génica. Brevemente se realizó una extracción de ARN celular total, luego la retrotranscripción y la PCR con los cebadores específicos, utilizando como molde los ADNc obtenidos. En la Figura 23 se observan las bandas de PCR obtenidas, las cuales corresponden al tamaño de los genes de las proteínas del VAE: 799 pb, correspondiente al gen gP5; 511 pb, del gen $\mathrm{M}$ y 380 pb, del gen N.

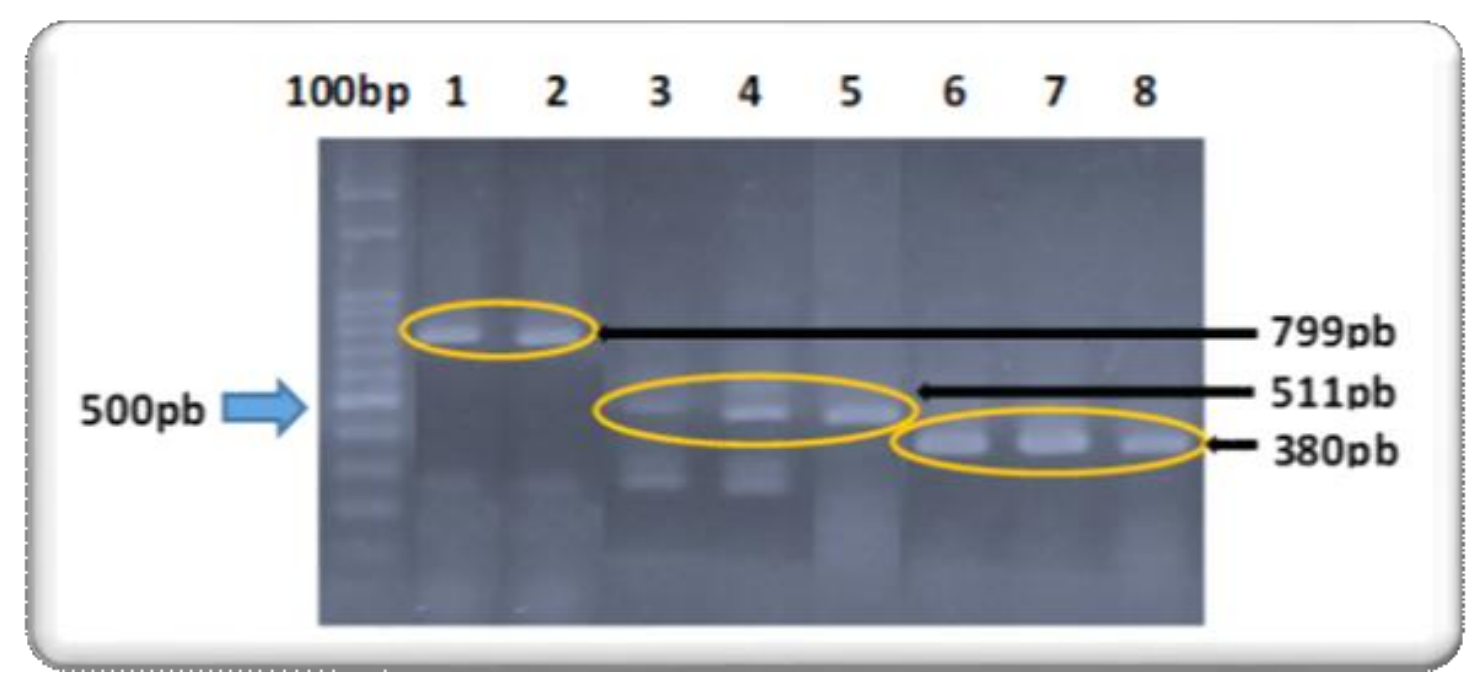

Figura 23: Análisis de la expresión por retrotranscripción del ARN mensajero y PCR con cebadores específicos de los genes gP5, M y N de las cepas del VAE. Se observan las bandas de PCR obtenidas, las cuales corresponden al tamaño de los genes de las proteínas del VAE: $799 \mathrm{pb}$, correspondiente al gen gP5; $511 \mathrm{pb}$, del gen M y $380 \mathrm{pb}$, del gen N. 1) PCR ADNc-gP5 Bucyrus. 2) PCR ADNc-gP5 GLD-LP-ARG. 3) PCR ADNc-M Bucyrus. 4) PCR ADNc-M LP-01. 5) PCR ADNc-M GLD-LP-ARG. 6) PCR ADNc-N Bucyrus. 7) PCR ADNC-N LP-01. 8) PCR ADNC-N GLD-LP-ARG.

Se evidenció la transcripción de todos los genes clonados en todas las construcciones realizadas. 


\section{Detección de apoptosis por fragmentación del ADN}

EI ADN fue extraído de todas las muestras, con excepción de RK-13-pCDNA-MGlad, debido a la poca masa celular presente al momento de realizar el ensayo, siguiendo el protocolo fenol/cloroformo, descripto en el apartado 15 de M\&M. Las muestras fueron corridas en un gel de agarosa al $1 \%$ con un marcador de peso molecular $100 \mathrm{pb}$ y se tiñeron con bromuro de etidio para visualizar la fragmentación del ADN internuclosomal típica de la apoptosis celular, que no ocurre en el control del pCDNA sin inserto, como se observa en la Figura 24.

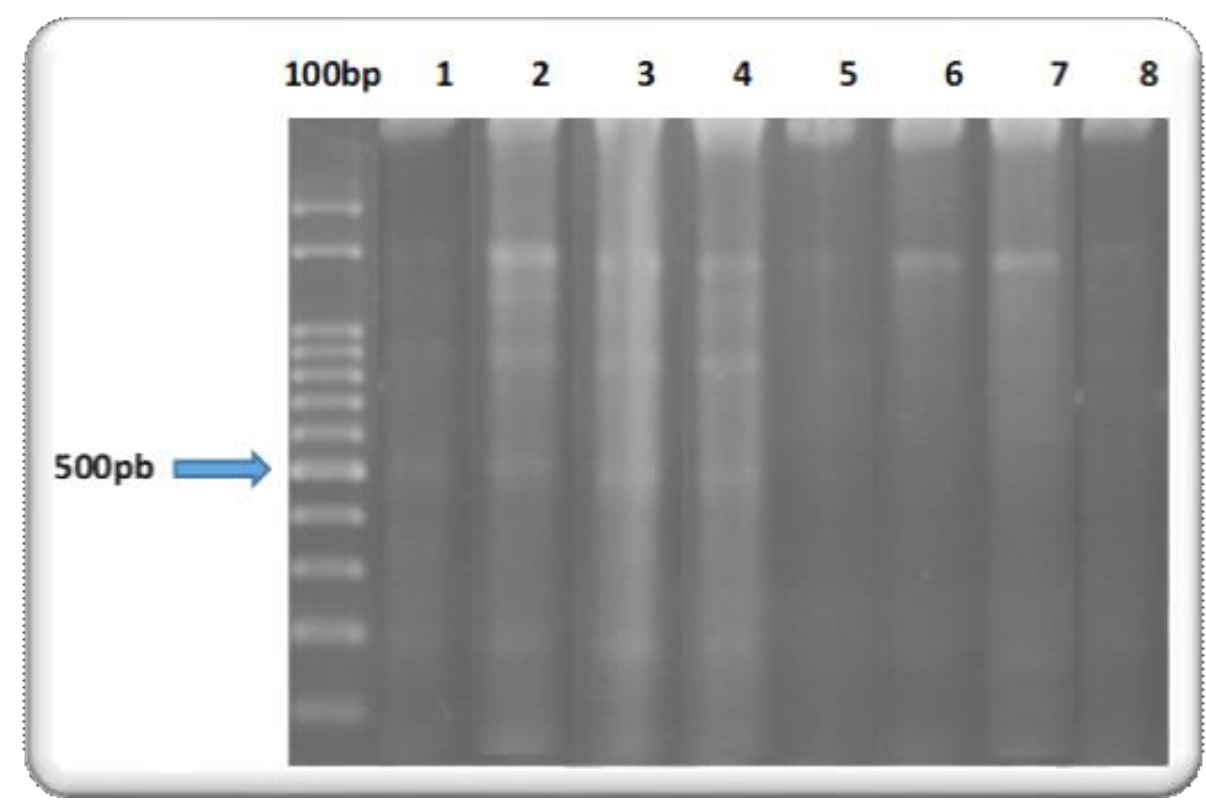

Figura 24: Detección de apoptosis por fragmentación del ADN de los cultivos RK-13 transfectados con los genes gP5, M y N de las cepas del VAE. Se visualiza la fragmentación del ADN internuclosomal típica de la apoptosis celular en todas las muestras, con excepción del control pCDNA (sin inserto). 1) ADN células RK-13-pCDNA-gP5 Bucyrus. 2) ADN células RK-13-pCDNA-M Bucyrus. 3) ADN células RK-13-pCDNA-N Bucyrus. 4) ADN células RK-13-pCDNA-gP5 GLD-LP-ARG. 5) ADN células RK-13-pCDNA-N GLD-LPARG. 6) ADN células RK-13-pCDNA-M LP-01. 7) ADN células RK-13-pCDNA-N LP-01. 8) ADN células RK-13-pCDNA.

\section{Detección de apoptosis por tinción diferencial (NA/BE)}

Las células fueron procesadas según lo descrito en la sección 16 de M\&M. En la Figura 25 se observan las células transfectadas con características morfológicas típicas de la 
apoptosis celular: redondeamiento, encogimiento, blebbing de membrana y cuerpos apoptóticos.

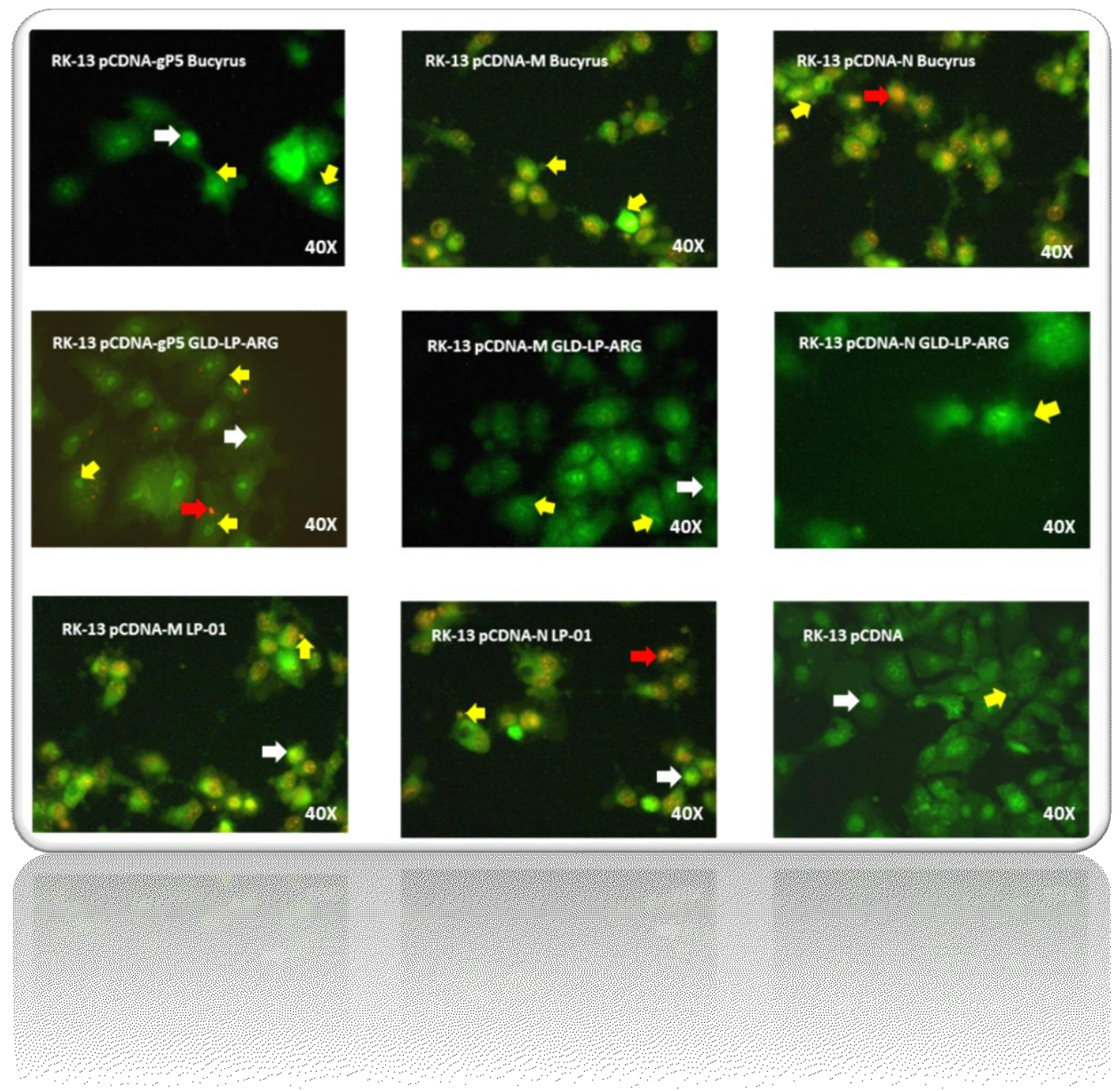

Figura 25: Detección de apoptosis por tinción diferencial (NA/BE) de los cultivos transfectados con las construcciones pCDNA de los genes gP5, $\mathbf{M}$ y $\mathbf{N}$ de las cepas del VAE. Se observan las células transfectadas con características morfológicas típicas de la apoptosis celular: redondeamiento, encogimiento, blebbing de membrana y cuerpos apoptóticos. Flechas blancas: células intactas. Flechas amarillas: células apoptóticas. Flechas rojas: células necróticas 1) NABE RK-13 -pCDNA-gP5 Bucyrus. 2) NABE RK-13 -pCDNA-M Bucyrus. 3) NABE RK-13 -pCDNA-N Bucyrus. 4) NABE RK-13 -pCDNA-gP5 GLD-LP-ARG. 5) NABE RK-13 -pCDNAM GLD-LP-ARG. 6) NABE RK-13 -pCDNA-N GLD-LP-ARG. 7) NABE RK-13 -pCDNA-M LP-01. 8) NABE RK-13 -pCDNA-N LP-01. 9) NABE RK-13-pCDNA. 


\section{Detección de apoptosis por citometría de flujo}

Las muestras fueron cultivadas y procesadas según se detalló en la sección 17 de M\&M. En los estudios de citometría también evaluamos el porcentaje de células apoptóticas de los cultivos transfectados tras la infección de los mismos con el virión completo (para ello infectamos los distintos cultivos celulares con MOI de 1 de la cepa Bucyrus) o el tratamiento con STS a una concentración de $1 \mu \mathrm{g} / \mathrm{ml}$. Los datos informáticos arrojados por el citómetro FACScan fueron graficados utilizando el programa FlowJo.

En la Figura 26 se observan los gráficos y porcentajes de apoptosis observados en los cultivos celulares transfectados con distintas proteínas del VAE y el control negativo (pCDNA). En el panel A se observan los valores de apoptosis basal; en el panel B se observan los porcentajes de apoptosis luego de la infección viral con la cepa Bucyrus (MOI 1). Por último, en el Panel $C$ se encuentran los valores apoptóticos registrados luego del tratamiento con STS. Lamentablemente el único cultivo transfectado que no fue sometido a citometría fue el correspondiente a la transfección pCDNA-M GLD-LP-ARG, debido a que el mismo contaba con muy pocas células en monocapa al momento de realizar la técnica. 

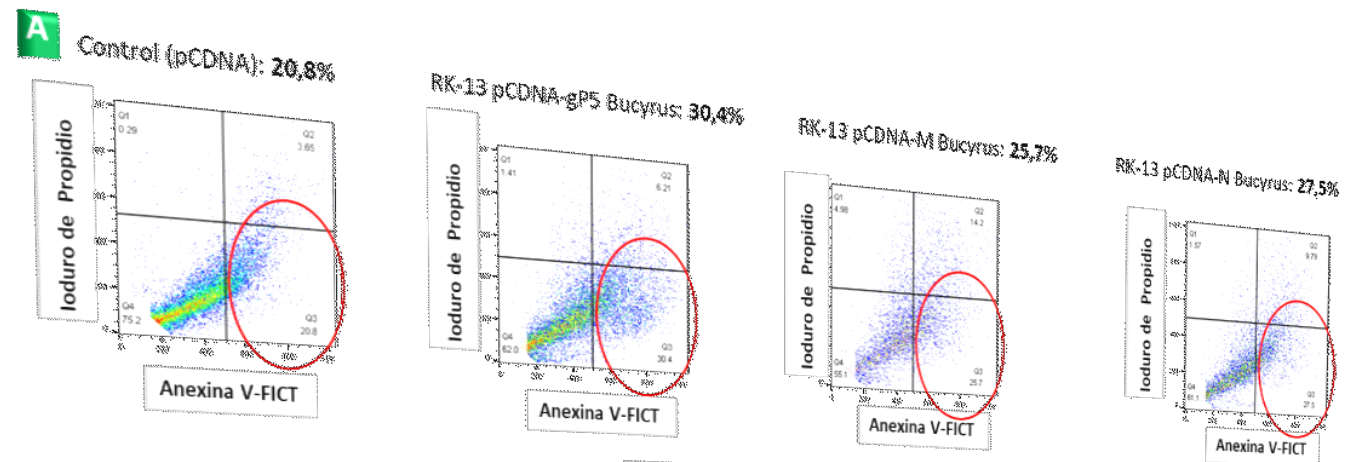

\section{RK-13 Transfectadas}

PK. 13 pCONW

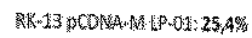

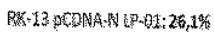
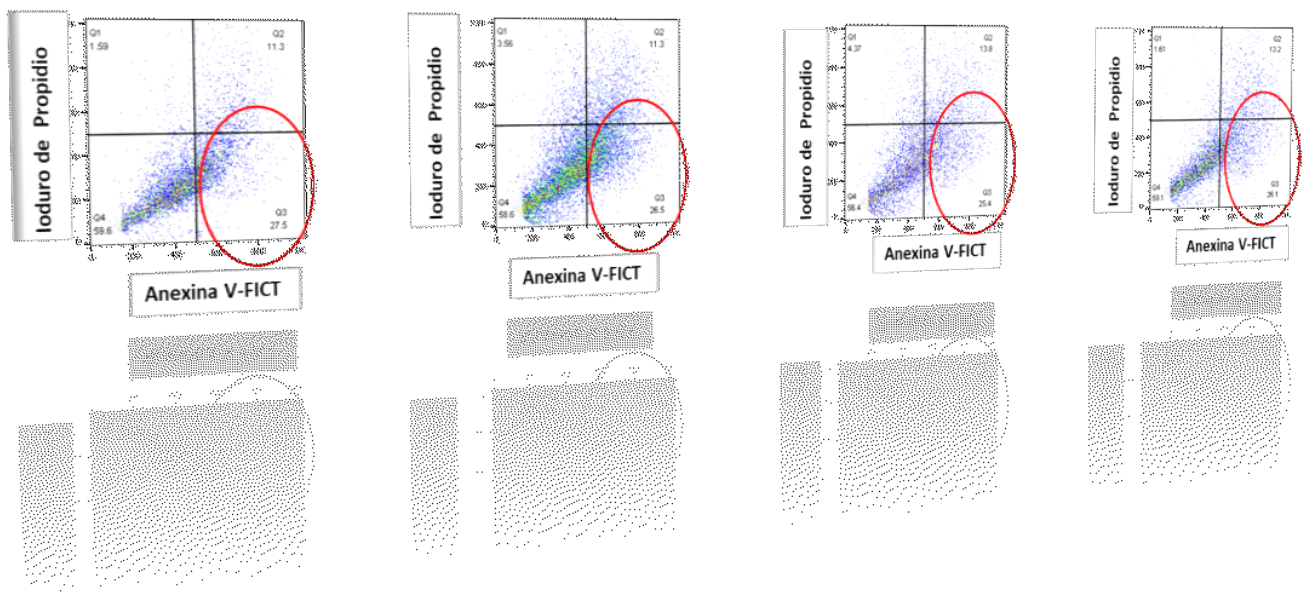
B

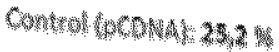
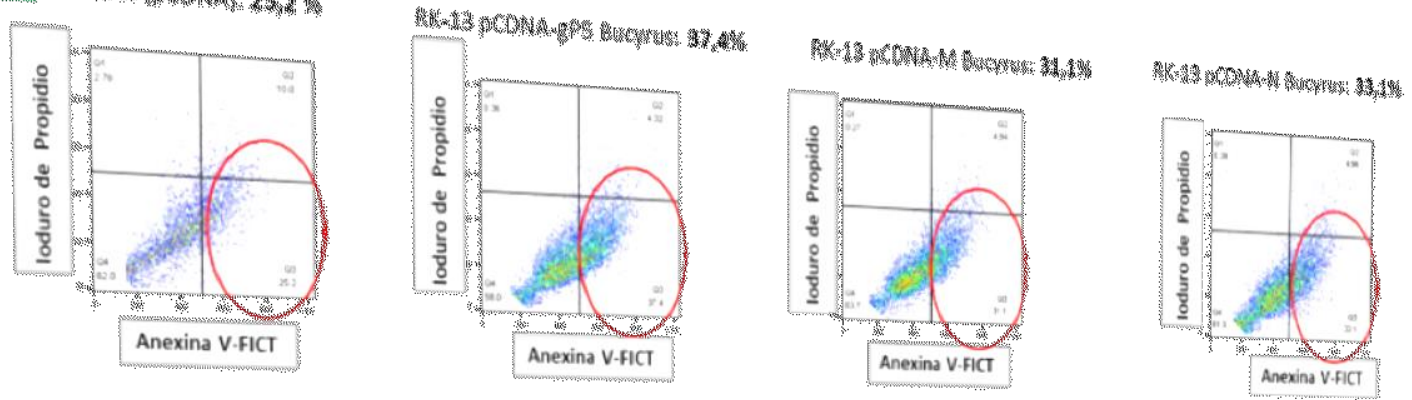

\section{RK-13 Transfectadas + VAE}

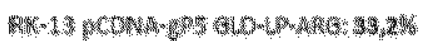

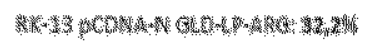
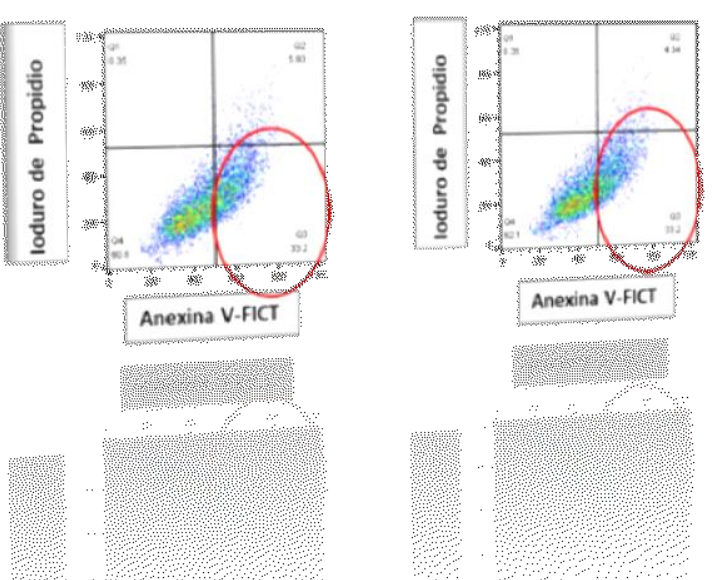

M.
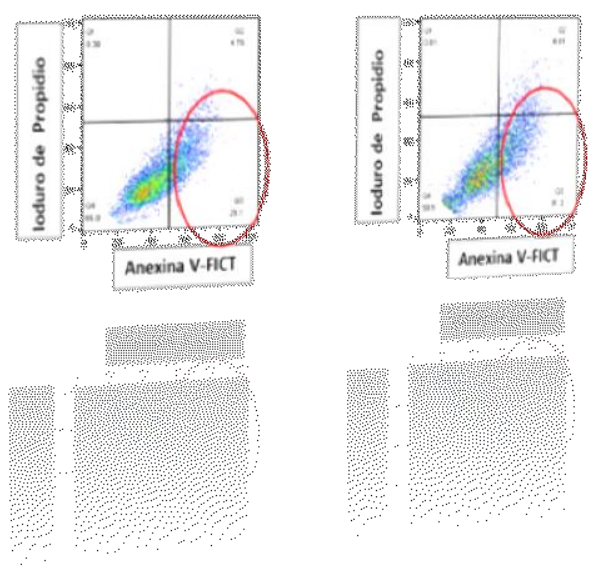

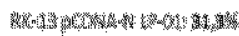

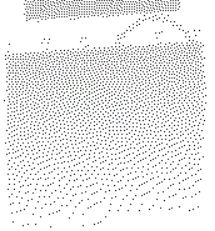



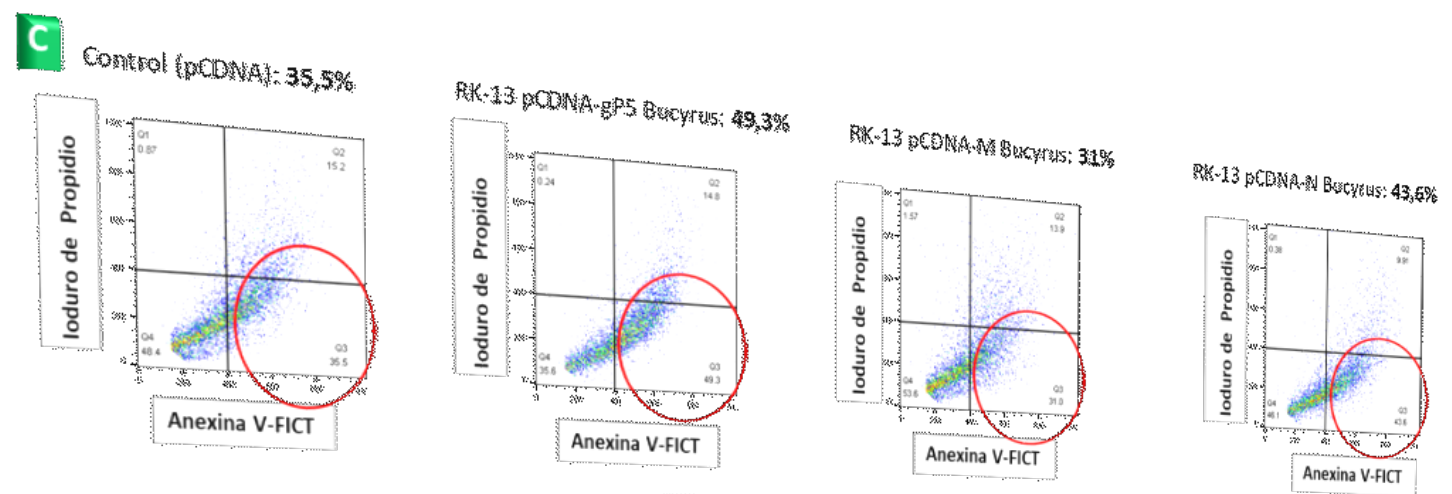

\title{
RK-13 Transfectadas + STS
}

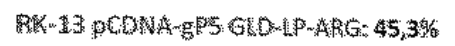

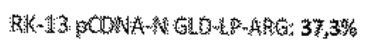

R

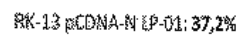
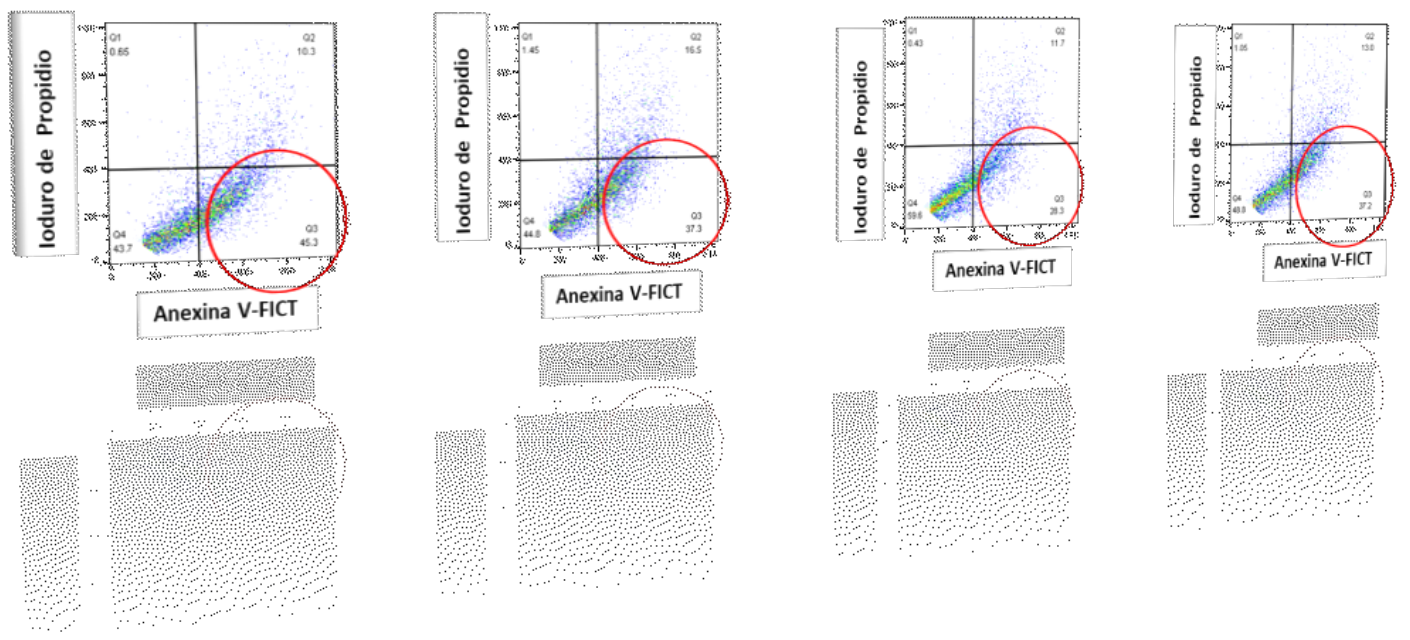

\begin{abstract}
Figura 26: Detección de apoptosis por citometría de flujo de los cultivos transfectados con las construcciones pCDNA de los genes gP5, M y N de las cepas del VAE. Se observan los gráficos y porcentajes de apoptosis observados (cuadrante Q3) de los cultivos celulares transfectados con distintas proteínas del VAE y el control negativo (vector vacío). Los datos informáticos arrojados por el citómetro FACScan fueron graficados utilizando el programa FlowJo. A) \% apoptosis basal. B) \% apoptosis postinfección viral con la cepa Bucyrus del VAE (MOI 1). C) \% apoptosis post-tratamiento con staurosporina (1 $\mathrm{\mu g} / \mathrm{ml})$.
\end{abstract}

Con el objetivo de visualizar en conjunto los datos de los gráficos de citometría se realizó una tabla donde se encuentra la información del porcentaje celular en apoptosis temprana (cuadrante Q3) en todas muestras. En la Tabla 7 se observan los datos arrojados por la citometría en forma fácilmente comparable. 


\begin{tabular}{|c|c|c|c|}
\hline Muestra & \% Apoptosis Basal & $\begin{array}{l}\% \text { Apoptosis post- } \\
\text { infeccion VAE }\end{array}$ & $\begin{array}{l}\text { \% Apoptosis post- } \\
\text { tratamiento STS }\end{array}$ \\
\hline RK-13 pCDNA & 20,8 & 25,2 & 35,5 \\
\hline RK-13 pCDNA-gPS Bucyrus & 30,4 & 37,4 & 49,3 \\
\hline RK-13 pCDNA-M Bucyrus & 25,7 & 31,1 & 31 \\
\hline RK-13 pCDNA-N Bucyrus & 27,5 & 33,1 & 43,6 \\
\hline RK-13 pCDNA-gP5 GLD-LP-ARG & 27,5 & 33,2 & 45,3 \\
\hline RK-13 pCDNA-N GLD-LP-ARG & 26,5 & 32,2 & 37,3 \\
\hline RK-13 pCDNA-M LP-01 & 25,4 & 29,1 & 28,3 \\
\hline RK-13 pCDNA-N LP-01 & 26,1 & 31,3 & 37,2 \\
\hline
\end{tabular}

Tabla 7: Diagramas con los valores de citometría de cultivos celulares transfectados con las construcciones pCDNA de los genes gP5, M y N de las cepas del VAE. Se observa que la proteína gP5 de la cepa Bucyrus produjo el mayor porcentaje de apoptosis $(30,4 \%)$, mientras que gP5 de GLAD-LP-ARG indujo un 27,5\%. La proteína M manifestó una diferencia despreciable en el nivel de apoptosis inducido por cepas más y menos patogénicas (25,7\% en M de Bucyrus y 25,4 en M de LP-01). Nuestros resultados con respecto a la proteína $\mathrm{N}$ también expresan el predominio proapoptótico en la cepa Bucyrus (27,5\%), seguida de GLAD-LP-ARG (26,5\%), y la inducción de apoptosis más discreta de la cepa apatógena LP-01 (26,1\%). Todos los valores expresados por las construcciones del VAE son claramente superiores a los del vector pCDNA vacío $(20,8 \%)$.

\section{Detección de caspasas-3,-8 y-9 in situ por inmunotinción}

Para detectar la activación de caspasas en los cultivos transfectados y control (mock), se utilizó la metodología descrita en la sección 18 de M\&M. Cubreobjetos crecidos con cada cultivo celular transfectado fueron incubados con los Ac específicos para caspasas -3, -8 y -

9, todos ellos tipo policlonal de cabra. Para evidenciar el reconocimiento del Ac secundario (IgG anti-cabra de conejo conjugado con HRP) se utilizó AEC como cromógeno para la enzima peroxidasa de rábano picante, revelándose la reacción enzimática con un precipitado rojizo. Para esta técnica también se utilizó un control positivo de células RK13, donde la apoptosis fue inducida por medio de STS a una concentración de $1 \mu \mathrm{g} / \mathrm{ml}$. Los 
cubreobjetos procesados fueron examinados por microscopía invertida. En la Figura 27 se observa la activación de las caspasas en los cultivos transfectados y controles positivos, visualizada como un precipitado rojizo. En la Figura 27.A se analizó la actividad de la caspasa-3 (vía ejecutora común), en la Figura 27.B se observa la activación de la caspasa-8 (vía extrínseca) y, por último, en la Figura 27.C se visualiza la actividad de la caspasa-9 (vía intrínseca). 


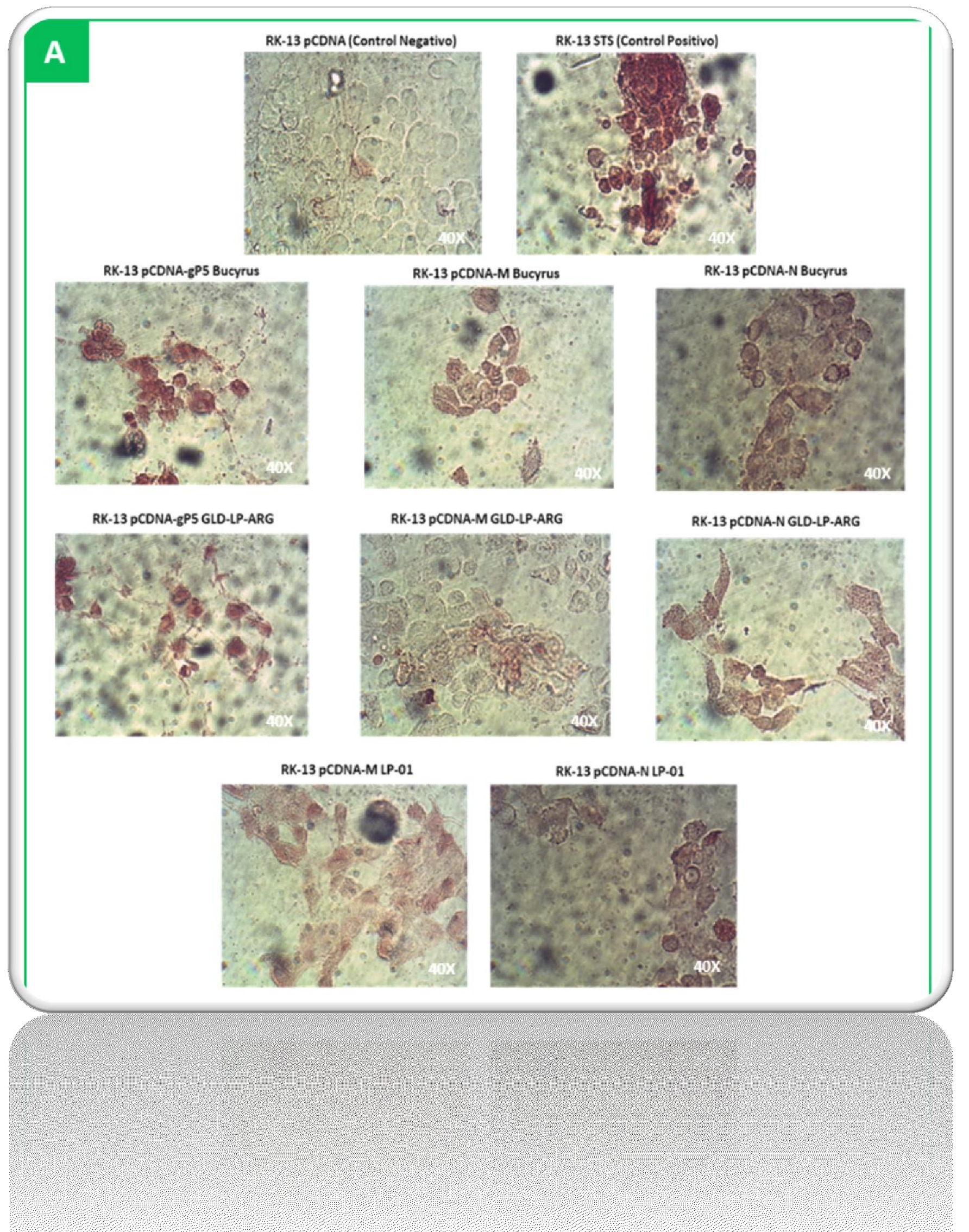




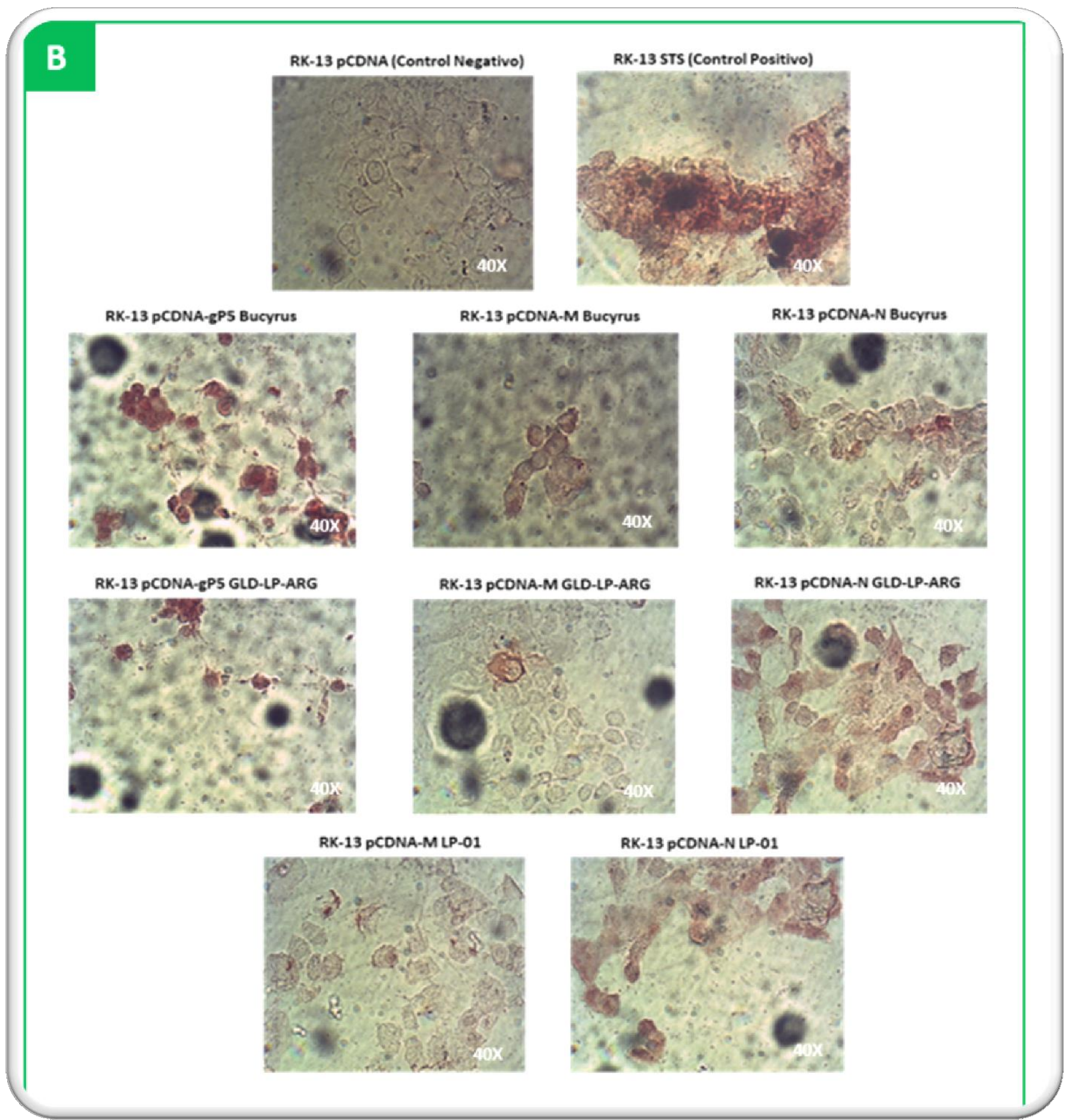




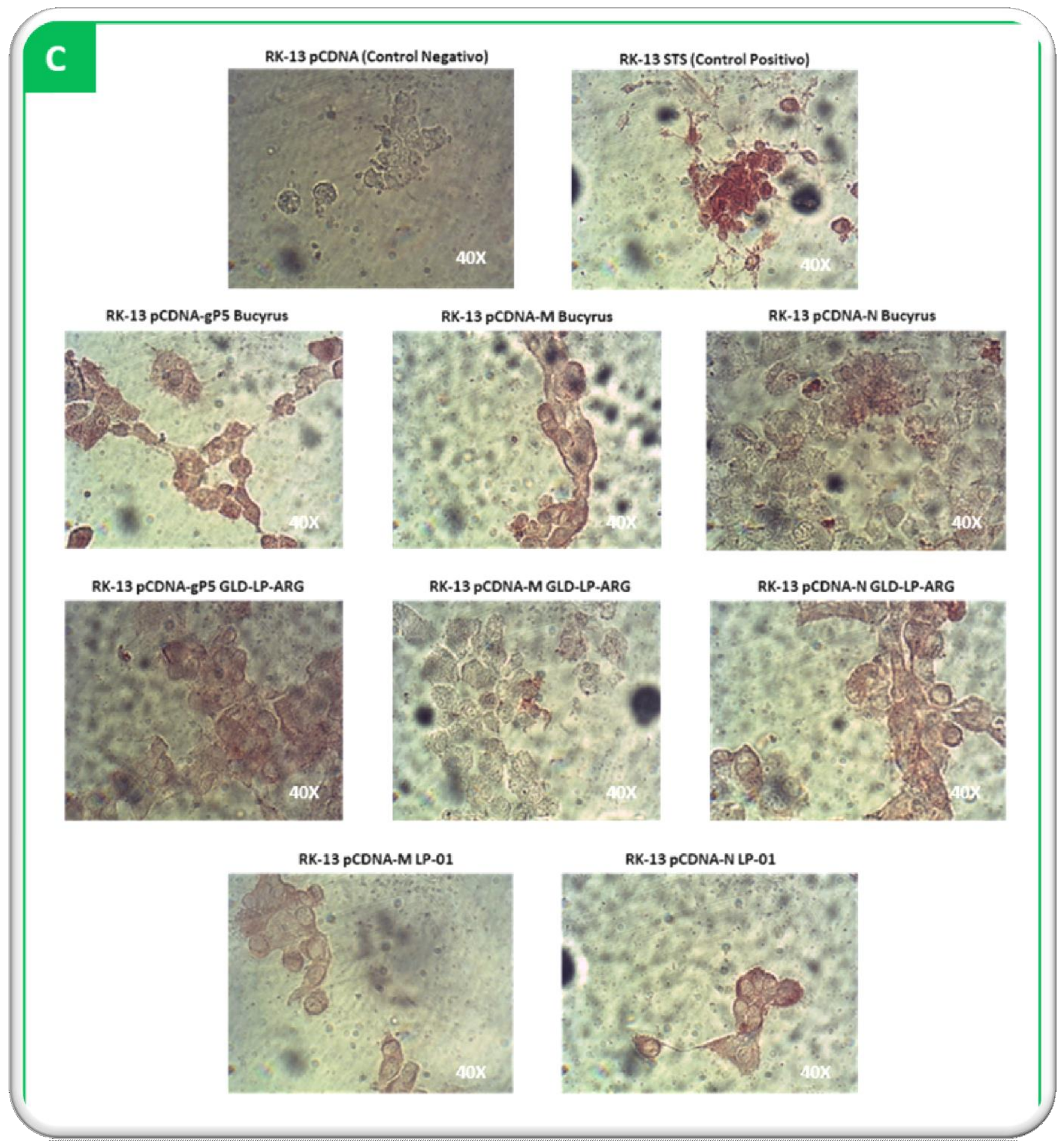


Figura 27: Detección de apoptosis por activación de caspasas detectada por inmunotinción de los cultivos transfectados con las construcciones pCDNA de los genes gP5, $\mathbf{M}$ y $\mathbf{N}$ de las cepas del VAE. Se observa la activación de las caspasas en los cultivos transfectados y controles positivos, visualizada como un precipitado rojizo. A) Detección de caspasa-3 activada. B) Detección de caspasa-8 activada. C) Detección de caspasa-9 activada.

Luego de las pruebas realizadas en este capítulo para determinar la existencia y el tipo de apoptosis de los cultivos transfectados con las proteínas clonadas de las tres cepas del VAE, concluimos que este proceso existe y estaría relacionado con las proteínas expresadas al igual que con la patogenicidad de la cepa viral correspondiente.

En cuanto a la proteína expresada, observamos mayor \% de apoptosis (cuadrante Q3 de los gráficos de citometría) en las construcciones recombinantes conteniendo el gen de la proteína gP5, mientras que el menor \% se observó en las construcciones que contenían el gen de la proteína M.

Con respecto a las cepas utilizadas, los genes de la cepa de referencia Bucyrus (alta patogenicidad) expresados en los cultivos transfectados fueron responsables de los mayores \% de apoptosis registrados (cuadrante Q3 de los gráficos de citometría), seguido en menor grado por GLD-LP-ARG mientras que la cepa apatógena LP-01 manifestó valores de apoptosis similares al control de mock (vector pCDNA vacío). 


\section{Capítulo 3: Experiencias complementarias \\ -detección de caspasa 12- \\ -uso de Inhibidores específicos-}

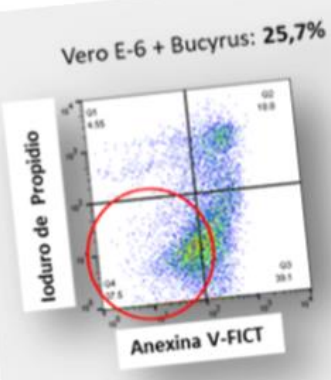

VAE: $25,7 \%$ sobrevida

Vero E-6 + ZVA-D-FMK + Bucyrus: $79.3 \%$

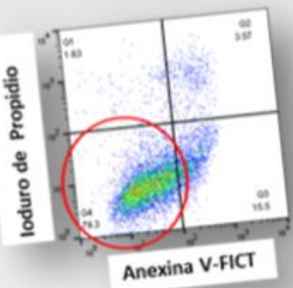

VAE + Inhibidor Apoptosis: 79,3\% sobrevida

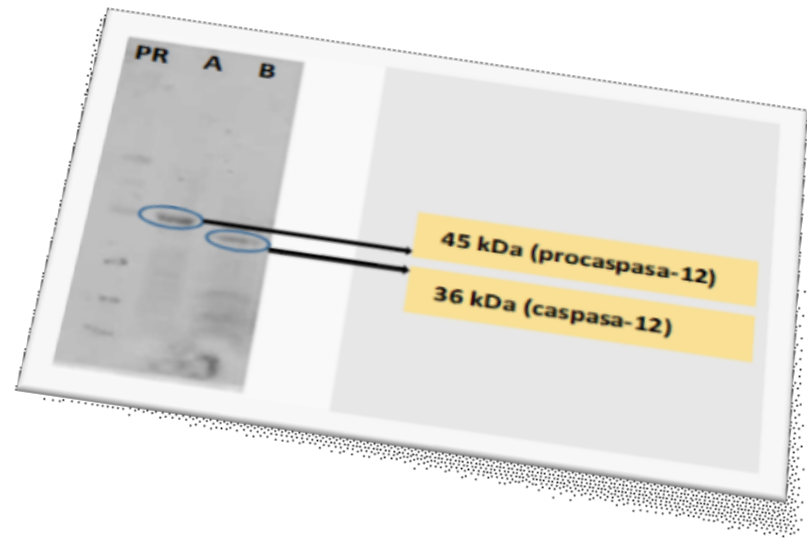


1. MATERIALES Y MÉTODOS:

- Virus

- Células

- Western Blot

- Inhibidores

-Inhibidor de la pan-caspasas: ZVAC-FMK

-Inhibidor de caspasa-12: Z-ATA-FMK

- Citometría de flujo y software FlowJo

2. RESULTADOS:

- Detección de la activación de la caspasa-12 por Western Blot

- Determinación de la actividad del inhibidor de caspasa-12 (Z-ATA-FMK) por citometría de flujo

EXPERIENCIA 2: EFECTO CITOPÁTICO DEL VAE: MUERTE CELULAR DEPENDIENTE DE CASPASAS COMO LA PRINCIPAL CONSECUENCIA OBSERVADA

\section{MATERIALES Y METODOS}

- Células

- Cepa viral

- Inhibidores específicos:

-Necrostatina-1

-3-Metiladenina 
-Z-VAD-FMK

- Detección de la apoptosis mediante análisis de citometría de flujo utilizando Anexina V FICT y loduro de propidio

\section{RESULTADOS}

- Supervivencia celular en células infectadas tras la incubación con los distintos inhibidores de muerte celular 
Durante el transcurso de esta tesis doctoral fui beneficiada con una beca de la Comisión BEC.AR-Fullbright, lo que me permitió trabajar durante 9 meses en el Virology Center de Lincoln, Nebraska, USA, con los Dres. Fernando Osorio y Rodrigo Franco Cruz.

Durante mi estadía realicé dos experiencias que considero están muy relacionadas con la temática de esta tesis doctoral, si bien no están incluidas dentro de los objetivos específicos. Por un lado, se analizó la importancia cuali y cuantitativamente de la vía del RE (representada por la caspasa-12), en la infección por el VAE mediante el uso de inhibidores específicos.

Para estas experiencias trabajamos con la cepa Bucyrus y la línea celular VeroE6, debido a que eran los reactivos con los que contaba el laboratorio a mi llegada y mis supervisores consideraron óptimos para estas experiencias.

\section{EXPERIENCIA 1: LA INFECCIÓN POR EL VIRUS DE LA ARTERITIS EQUINA Y LA RESPUESTA}

\section{AL ESTRÉS DEL RETICULO ENDOPLASMÁTICO EN CULTIVOS CELULARES}

El RE es una organela importante en la replicación del VAE, como se explicó en la sección Introducción. En esta experiencia se intentó demostrar la existencia de la respuesta del RE al estrés causado por la infección viral a través de la activación de la caspasa-12 (enzima específica del RE). Esta respuesta representa un mecanismo para degradar las proteínas mal plegadas originadas durante el estrés fisiológico o patológico. Cuando los daños causados por el estrés se vuelven irreparables esta organela inicia la apoptosis. Nuestro objetivo es analizar si la infección por el VAE activa la caspasa-12 como respuesta al estrés en los cultivos infectados, y en qué medida es representativa. 


\section{MATERIALES Y MÉTODOS}

- Virus: como cepa de VAE se utilizó Bucyrus a una MOI de 0,25.

- Células: Se utilizaron monocapas de células Vero E6 con $80 \%$ de confluencia dispuestas en placas de 6 pocillos. Las monocapas se infectaron con el VAE e incubaron durante una $\mathrm{h}$ a $37^{\circ} \mathrm{C}$ en una atmósfera con un $5 \%$ de $\mathrm{CO}_{2}$. Transcurrido este tiempo, se eliminó el inóculo y se mantuvo en el medio MEM con el 2\% de SFB en las mismas condiciones de incubación, siendo cosechado a 72 hpi. Como controles negativos se utilizaron cultivos no infectados.

- Western Blot: a 72 hpi, se recolectaron células y se prepararon para su análisis por WB siguiendo el Protocolo comercial (Thermo Fisher Scientific).

1. Como Ac primario se utilizó: Ac anti- caspasa-12 activa, de conejo, diluido 1:500 en PBS (Abcam)

2. Como Ac secundario se utilizó: Ac anti-conejo conjugado con peroxidasa dilución 1:1000 (Sigma-Aldrich). La evidencia el reconocimiento del Ac secundario fue posible por el uso peróxido de hidrógeno como el substrato para la enzima peroxidasa y de DAB como cromógeno.

- Inhibidores: Todos ellos fueron evaluados individualmente de la siguiente manera: las monocapas fueron sometidas a la acción del inhibidor, 1 h previo a la infección viral, mientras los controles negativos fueron tratados con el mismo volumen del diluyente de los inhibidores: DMSO (Dimetil sulfóxido).

Luego de la infección viral $(1$ h), se retiró el inóculo y se añadió medio de cultivo (MEM con $2 \%$ de SFB) donde las células se mantuvieron hasta el final del experimento, con la 
misma concentración de inhibidores inicialmente utilizados. Los inhibidores utilizados fueron:

1. Inhibidor de la pan-caspasas: se usó ZVAC-FMK $100 \mu \mathrm{M}$ (Abcam), con el fin de inhibir la activación de las caspasas y, por lo tanto, todas las vías de apoptosis.

2. Inhibidor de caspasa-12: se usó Z-ATA-FMK $100 \mu \mathrm{M}$ (Abcam) con el propósito de inhibir únicamente la activación de la caspasa 12 y, por ende diferenciar el \% de muerte por apoptosis.

- Citometría de flujo y software FlowJo: a $72 \mathrm{hpi}$, las células fueron recolectadas y analizadas por citometría de flujo siguiendo el protocolo comercial (Thermo Fisher Scientific). Después de resuspender las células, se marcaron con $5 \mu$ de anexina VFICT $(100 \mu \mathrm{g} / \mathrm{ml}$, BioLegand) y $1 \mu \mathrm{l}$ de ioduro de propidio $(50 \mu \mathrm{g} / \mathrm{ml}$, Thermo Fisher Scientific) como indicadores de apoptosis/necrosis, respectivamente y sometidos a citometría. Después de analizar 10.000 eventos, los resultados se graficaron utilizando el programa FlowJo.

Todas las muestras analizadas en este experimento fueron cosechadas a las $72 \mathrm{hpi}$, tiempo estandarizado al cual se evidencia el mayor ECP en las células infectadas por el VAE.

\section{RESULTADOS}

- Detección de la activación de la caspasa-12 por Western Blot

Se determinó la activación de la caspasa-12 tras la infección con el VAE. Para ello se realizó un WB a las 72 hpi donde pudimos detectar la procaspasa-12 inactiva (45 kDa) en 
las células de control negativo (Figura 28.A), mientras que en las células infectadas con el VAE (Figura 28.B) fueron detectadas ambas: procaspasa y caspasa-12 (36 kDa).

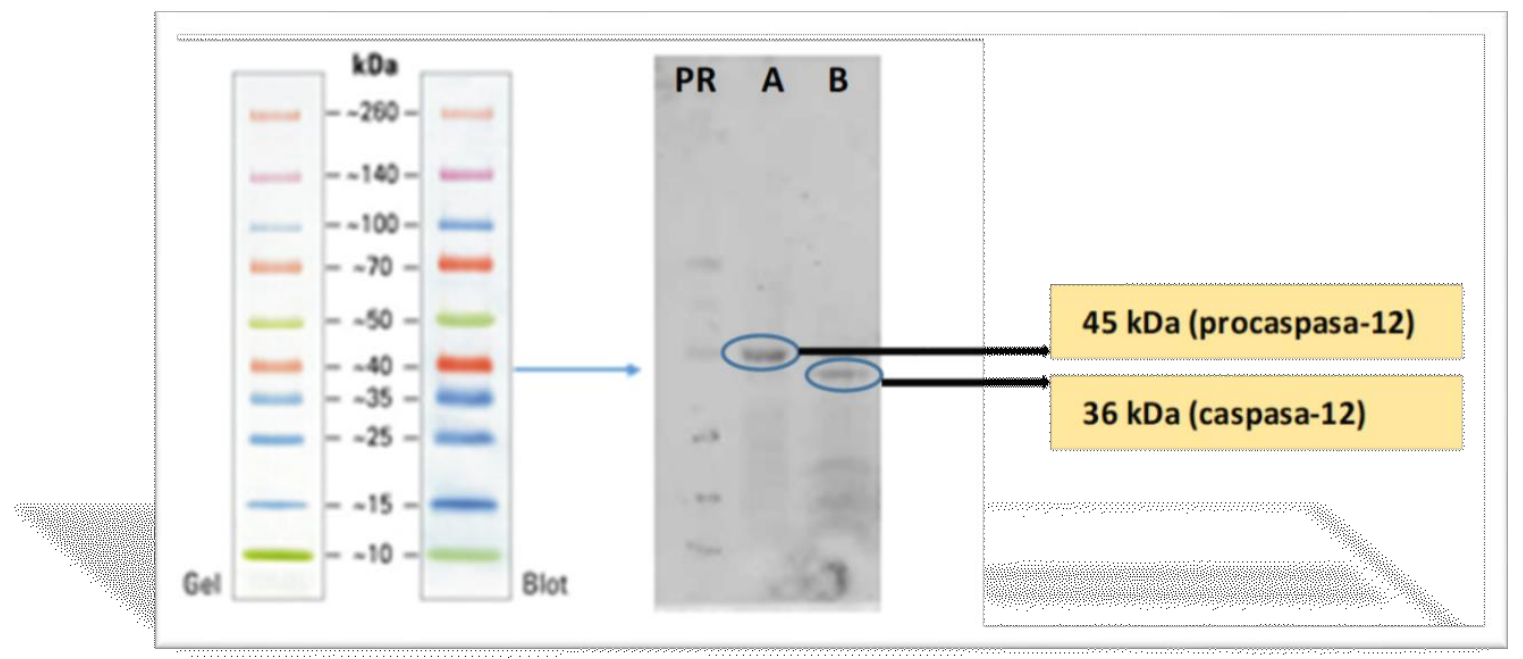

Figura 28: Detección de la activación de la caspasa-12 por Western Blot. Se puede observar en las células control negativo la presencia de procaspasa-12 (inactiva: $45 \mathrm{kDa}$ ); mientras que en las células infectadas con el VAE fueron detectadas las formas inactiva y activa de la caspasa-12 (activa: 36 kDa). PR: Page Ruler. A) Células sin infectar (control negativo). B) Células infectadas con la cepa Bucyrus del VAE.

- Determinación de la actividad del inhibidor de caspasa-12 (Z-ATA-FMK) por

\section{citometría de flujo}

En este ensayo, se comparó el porcentaje de células en apoptosis/necrosis observada (Q2 y Q3), es decir, el total de muerte observada, en los cultivos controles y tratados con los inhibidores.

Los resultados de citometría revelaron a las $72 \mathrm{hpi}$, un $25 \%$ de muerte en las células control negativo sin infectar, un $54,5 \%$ en las células infectadas, $38,4 \%$ en las células infectadas pero previamente tratadas con el inhibidor de pan-caspasas Z-VAD-FMK, y por último, un $44,4 \%$ en células infectadas pero anteriormente tratadas con el inhibidor de caspasa-12 Z-ATA-FMK (Figura 29). 
Vero E-6 sin infectar: $\mathbf{2 5 , 4 \%}$

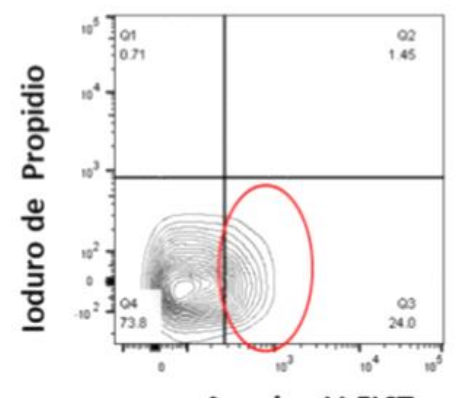

Anexina V-FICT

Vero E-6 + Z-VAD-FMK + Bucyrus: $\mathbf{3 8 , 4 \%}$

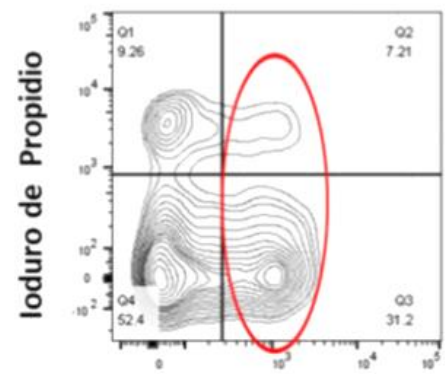

Anexina V-FICT
Vero E-6 + Bucyrus: $\mathbf{5 4 , 5 \%}$

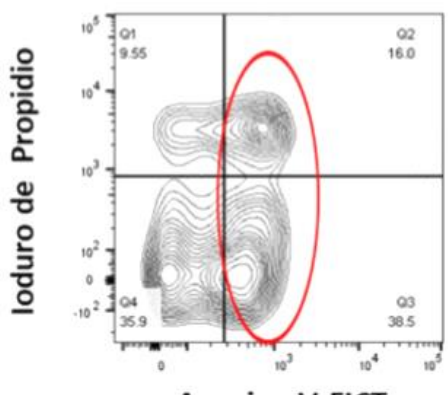

Anexina V-FICT

Vero E-6 + Z-ATA-FMK+ Bucyrus: $\mathbf{4 4 , 4 \%}$

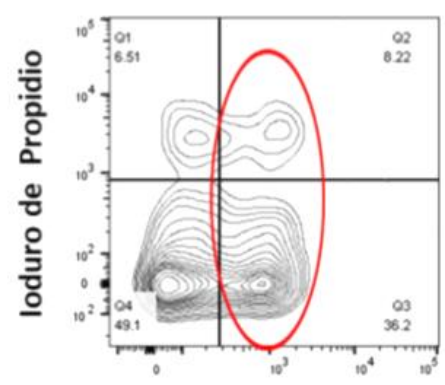

Anexina V-FICT

Figura 29: Determinación de la actividad del inhibidor de caspasa-12 (Z-ATA-FMK) por citometría de flujo. Se comparó el \% de células en apoptosis/necrosis observada (Q2 y Q3), es decir, el total de muerte observada, en los cultivos controles y tratados con los inhibidores. Los resultados fueron: $25 \%$ (control negativo), 54,5\% (VAE: control positivo), 38,4\% (VAE + inhibidor de pancaspasas), y por último, 44,4\% (VAE + inhibidor de caspasa-12). Se observa la considerable disminución de muerte observada tras el uso de los distintos inhibidores.

En la Tabla 8 se observan los valores de muerte celular obtenidos por citometría de flujo en la Figura 29, en forma fácilmente comparable. 


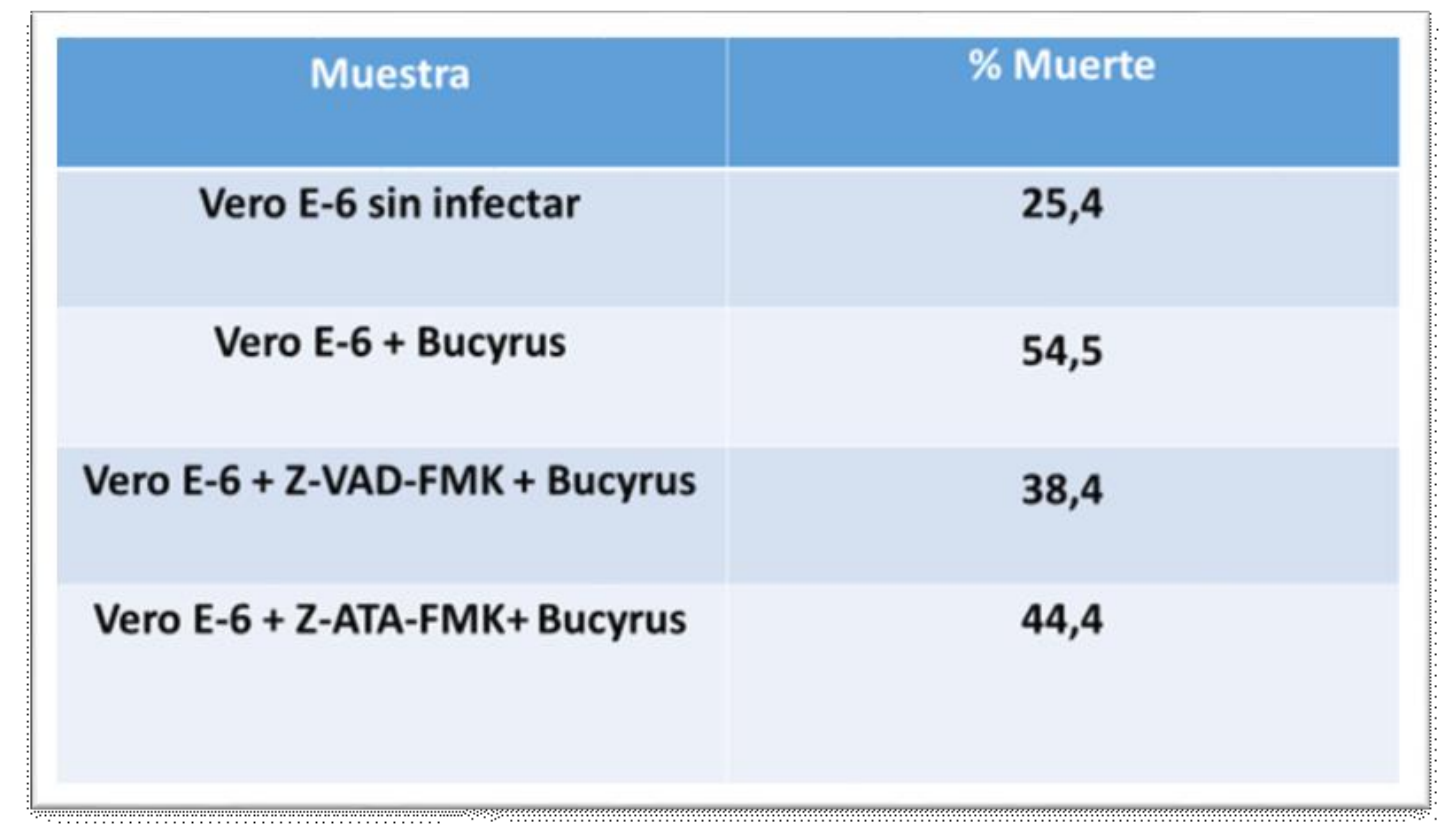

Tabla 8: Valores porcentuales de muerte celular obtenidos por citometría de flujo en la Figura 29. Los resultados fueron: $25 \%$ (control negativo), 54,5\% (VAE: control positivo), 38,4\% (VAE + inhibidor de pan-caspasas), y por último, 44,4\% (VAE + inhibidor de caspasa-12). Se observa la considerable disminución de muerte observada tras el uso de los distintos inhibidores.

Estos resultados demuestran la importancia de la caspasa 12 en la apoptosis inducida por el VAE, dado a que su sola inhibición produce una reducción importante en porcentaje de muerte celular (del $\mathbf{5 4 , 5 \%}$-cultivos infectados- al $\mathbf{4 4 , 4 \%}$-cultivos infectados tratados con el inhibidor Z-ATA-FMK). Considerando que el porcentaje de muerte basal del cultivo sin infectar a las 72 hs es de $\mathbf{2 5 , 4 \%}$, concluimos que el \% de sobrevida aportado por la inhibición de la vía del retículo es importante.

EXPERIENCIA 2: EFECTO CITOPÁTICO DEL VAE: MUERTE CELULAR DEPENDIENTE DE CASPASAS COMO LA PRINCIPAL CONSECUENCIA OBSERVADA

\section{MATERIALES Y METODOS}


- Células: se utilizaron monocapas con $80 \%$ de confluencia dispuestas en placas de 12 pocillos de la línea comercial Vero E6. La incubación de los inhibidores y los controles fueron idénticos a los explicados en la experiencia 1.

- Cepa viral: la cepa y el proceso de infección fueron los mismos explicados en la experiencia 1.

- Inhibidores específicos: para estudiar el efecto de los diversos mecanismos de muerte celular posiblemente responsables del ECP del VAE utilizamos diversos inhibidores.

-Necrostatina-1: Para analizar si la necrosis se encontraba implicada en el ECP del VAE,

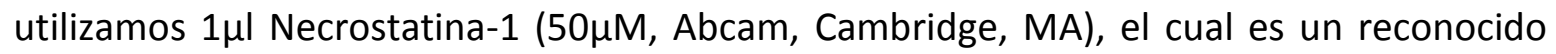
inhibidor de la RIPK1 quinasa, enzima fundamental del proceso de necrosis.

-3-Metiladenina: Para analizar la implicancia de la autofagia en el ECP del VAE utilizamos $1 \mu \mathrm{l}$ del inhibidor de autofagia 3-Metiladenina (50 mM, Sigma-Aldrich). El compuesto 3Metiladenina inhibe la autofagia bloqueando la formación de autofagosoma a través de la inhibición de la enzima fosfatidilinositol 3-quinasa (PI-3K).

-Z-VAD-FMK: Para estudiar la importancia de la muerte celular dependiente de caspasas en el ECP de las células infectadas por el VAE, utilizamos como inhibidor de pan-caspasas $1 \mu$ I Z-VAD-FMK (50 mM, Abcam, Cambridge, MA). Se trata de un inhibidor que se une irreversiblemente al sitio catalítico de las caspasas y puede inhibir la inducción de todo tipo de muerte celular dependiente de las mismas.

Todas las muestras analizadas en este experimento fueron cosechadas a las $72 \mathrm{hpi}$, tiempo estandarizado al cual se evidencia el mayor ECP en las células infectadas por el VAE. 
- Detección de la apoptosis mediante análisis de citometría de flujo utilizando Anexina V FICT + loduro de propidio

Las muestras se procesaron para citometría de flujo siguiendo los pasos descriptos en la experiencia 1. En este caso evaluamos supervivencia celular, reflejada en el cuadrante Q4 de los gráficos obtenidos.

\section{RESULTADOS}

En la Figura 30 se observan los gráficos obtenidos con el programa FlowJo, mientras que en la Tabla 9 se observan los valores porcentuales de cada ensayo, de forma fácilmente comparable.

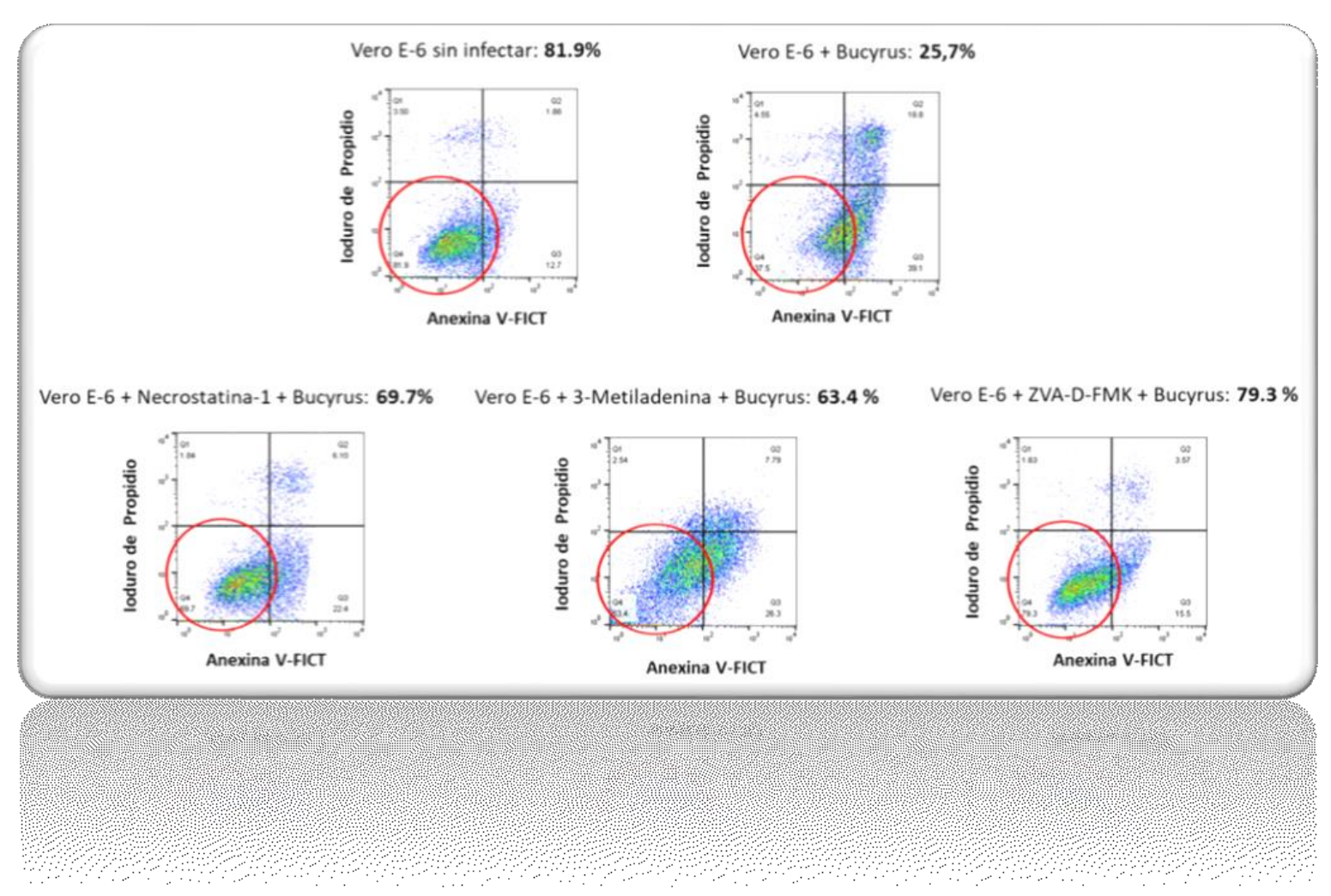


Figura 30: Determinación de la actividad de los distintos inhibidores de muerte por citometría de flujo. Se observa que al inhibir la apoptosis con ZVA-D-FMK, encontramos el mayor porcentaje de supervivencia celular $(79,3 \%)$ valor similar al observado en los cultivos de células Vero E6 no infectados (81,9\%).

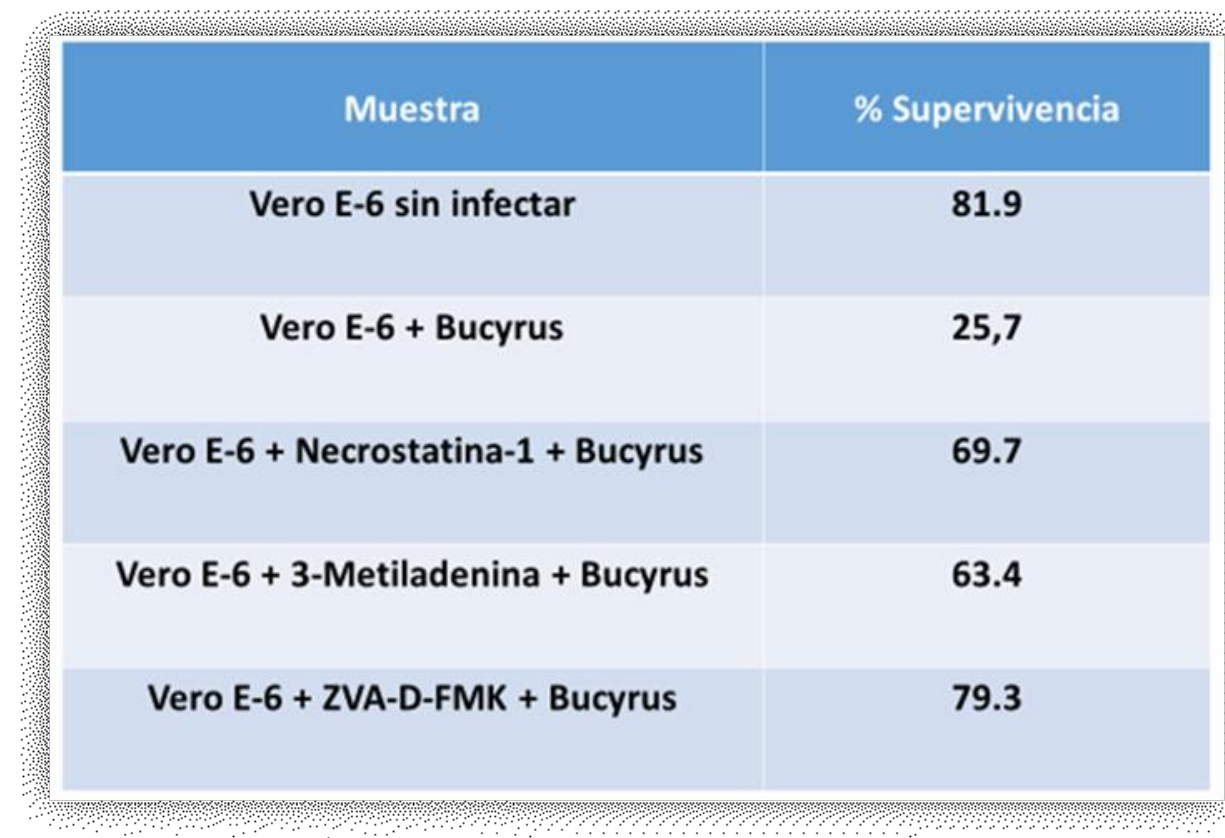

Tabla 9: Valores porcentuales de muerte celular obtenidos por citometría de flujo en la Figura 30. Estos \% indican la importancia crucial de la vía dependiente de caspasas en la lisis celular pi del VAE.

Los resultados demuestran que, cuando se inhibió la apoptosis con ZVA-D-FMK, observamos el mayor porcentaje de supervivencia celular $\mathbf{( 7 9 , 3 \% )}$ valor similar al observado en los cultivos de células Vero E6 no infectados (81,9\%). Estos hallazgos indican la importancia crucial de la vía dependiente de caspasas en la lisis celular pi del VAE.

Podemos concluir, gracias al uso de inhibidores de muerte específicos, que el mecanismo más importante en la lisis celular luego de infecciones por el VAE es la vía apoptótica dependiente de caspasas, si bien también aumento el \% de sobrevida al inhibir las otras vías de muerte. 


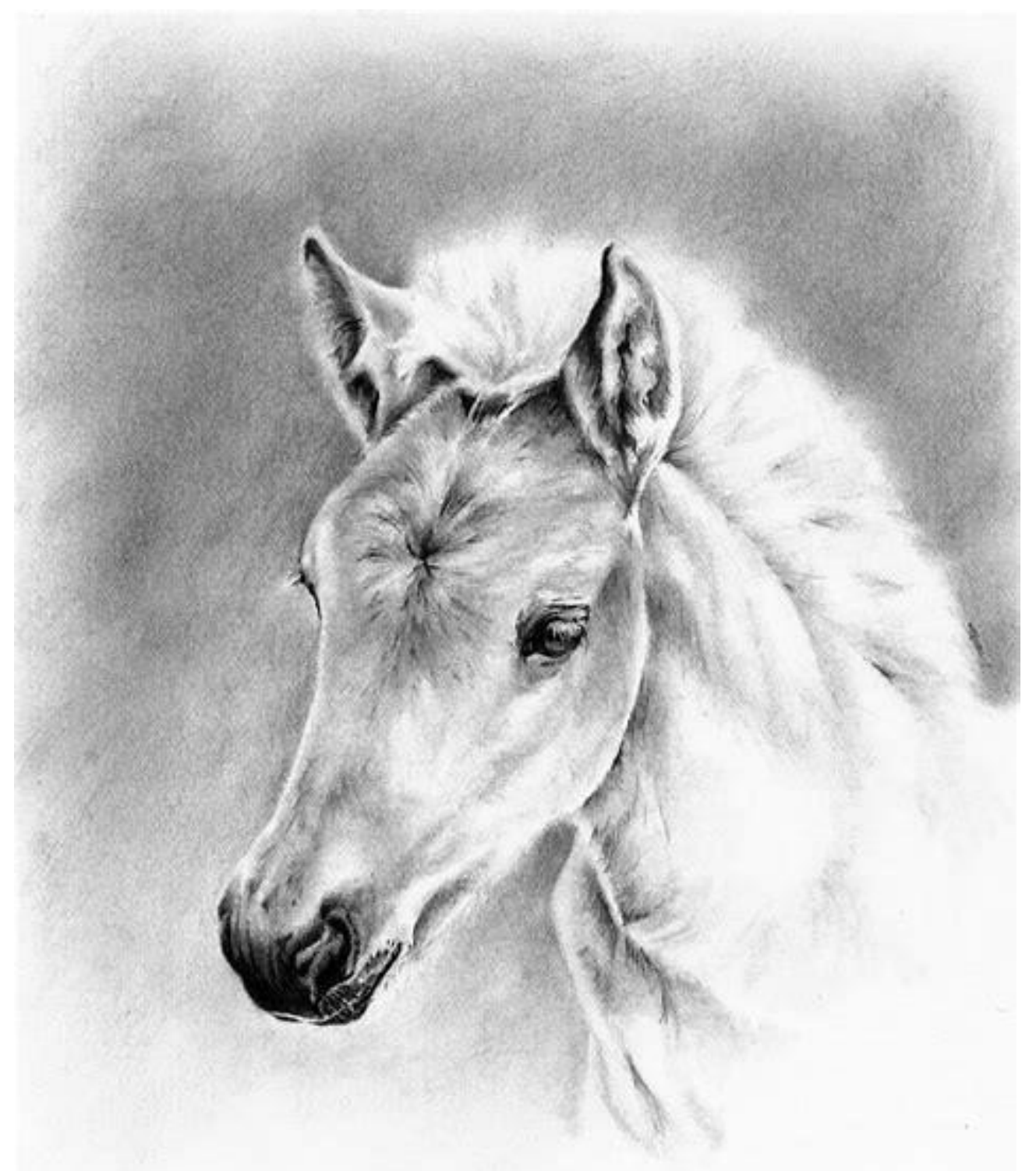

\section{Discusión}


Durante el transcurso de esta tesis doctoral, se llevaron a cabo diversas experiencias con el fin de relacionar la patogenicidad de las distintas cepas virales del VAE con la apoptosis celular evidenciada in-vitro. También se compararon los niveles de apoptosis en tres líneas celulares muy utilizadas en el diagnóstico luego de la infección con cepas del VAE. Igualmente relevante, y con el objetivo de estudiar el efecto de alguna de las proteínas estructurales más numerosas e inmunogénicas del virión, se diseñaron construcciones recombinantes con las cuales se transfectaron cultivos celulares. De esta manera se pudo evaluar cuali y cuantitativamente la importancia relativa de cada una de las proteínas en el proceso de apoptosis celular. Por último, mediante el uso de anticuerpos e inhibidores específicos pudimos evidenciar la importancia de la vía apoptótica del RE, representada por la caspasa-12; así como también determinar la menor participación de otras vías de muerte, como necrosis y autofagia. En cada capítulo, se utilizaron técnicas morfológicas y moleculares para determinar la ocurrencia de este proceso de muerte celular programada.

Los resultados del Capítulo 1 permiten afirmar que la magnitud de muerte celular observada en los cultivos celulares infectados está directamente relacionada con la patogenicidad de la cepa viral, la MOI utilizada y el tiempo de infección viral.

Mediante el análisis cualitativo (NA/BE) logramos establecer la existencia de cambios morfológicos asociados a la apoptosis y una dependencia directa entre la aparición de estos cambios y el tiempo pi a una misma MOI para las todas cepas y en todas las líneas celulares utilizadas. En este estudio pudimos evidenciar que a las $48 \mathrm{~h}$ pi los cambios son bien manifiestos sobre todo en células Vero, en comparación con RK-13. En BHK si bien 
observamos cambios morfológicos similares, estos se observan mayoritariamente a las 72 h pi, caracterizados por blebbing y aparición de cuerpos apoptóticos.

Para analizar la magnitud de lo observado anteriormente, utilizamos la técnica de citometría de flujo. En las infecciones con las tres cepas virales se evaluó cuantitativamente mediante dicha técnica los niveles de apoptosis a los mismos tiempos pi evaluados morfológicamente con la tinción NA/BE, confirmando que un grado más notable de apoptosis fue observado a medida que transcurrían las hpi. Si bien mediante los ensayos cualitativos se observaron mayores cambios morfológicos en las células Vero, los resultados de citometría arrojan una discordancia y demuestran que la línea celular RK-13 es la que manifiesta en mayor medida, y de forma más temprana, apoptosis tras la infección por el VAE, comparado con Vero y con BHK-21.

En este estudio encontramos también una marcada relación con la patogenicidad de la cepa y la MOI utilizada, donde la cepa Bucyrus (patogénica) presentó mayores niveles de apoptosis comparado con las otras cepas virales de estudio.

Varios autores concluyeron que la inducción de apoptosis desempeña un papel en la patogénesis viral (Archambault y St-Laurent, 2000; Lee y Kleiboeker, 2007; Miller y Fox, 2004; Suarez, 2000). En el caso del VAE, hay pocos trabajos que relacionan patogenicidad viral y magnitud de apoptosis. Cholleti y col. (2013) observaron los mismos resultados utilizando diferentes cepas del VAE (patógenas y no patógenas). Sin embargo, los gráficos de citometría del Capítulo 1 mostraron una clara diferencia en la capacidad de las distintas cepas virales para inducir apoptosis. Analizando los máximos valores de apoptosis inducida por las cepas del VAE, encontramos un dominio proapoptótico en Bucyrus (cepa 
patogénica americana: 55,6\% en RK-13, 72 hpi), seguida por GLD-LP-ARG (cepa patógena europea: 49,1\% en RK-13, 72 hpi), y por último se continua observando el menor efecto inductor en la cepa LP-01 (cepa no patógena europea: 41,3\% en RK-13, 72 hpi). Esta misma relación patogenicidad-apoptosis-células fue encontrada también y en el mismo orden en la línea celular Vero y BHK. Sin embargo, cabe destacar que los valores porcentuales obtenidos por citometría en BHK, son significativamente menores que en el resto de las células.

Otros estudios en BHK-21 infectadas con el virus de la estomatitis vesicular evidenciaron un retardo en la inducción de la apoptosis en comparación con células HeLa infectadas con el mismo virus (Kopecky y Lyles, 2003) y concluyeron que las células de la línea BHK-21 necesitarían de la expresión específica de genes adicionales para iniciar una respuesta apoptótica frente a la infección viral.

Otros estudios realizados con cepas del VAE mostraron que las infecciones en BHK inducen sólo la vía intrínseca de apoptosis (Cholleti y col., 2013; Metz y col., 2018), mientras que infecciones en Vero y RK-13 inducen tanto la vía intrínseca como la extrínseca (St. Louis y Archambault, 2007; Metz y col., 2016). Esto podría ser una de las causas en el retraso en la aparición de apoptosis debido a mayores estímulos apoptóticos en las líneas celulares Vero y RK-13, lo cual merecería ser profundizado en futuros estudios con la línea BHK.

Respecto a otro virus pero de la misma familia, existen estudios que relacionan patogenicidad viral del VSRRP con apoptosis in vivo. Wang y col. (2014a) observaron que el alto número de células apoptóticas en los órganos linfáticos y el pulmón inducido por la 
cepa altamente patógena HuN4 estaría relacionado con la alta mortalidad observada en cerdos. Algo similar fue observado por Han y col. (2016) quienes evidenciaron un número significativamente mayor de células apoptóticas pulmonares en los cerdos infectados con VSRRP tipo 2 (cepa altamente patógena) en comparación con la infección por el VSRRP tipo 1. Otra investigación que relaciona la patogenicidad viral de los arterivirus con la apoptosis observada in vivo es la de Amarilla y col. (2016), quienes concluyen que la infección viral por el VSRRP indujo el agotamiento de la corteza tímica debido a la apoptosis de los timocitos, siendo este agotamiento más severo cuando se asocia a la cepa altamente virulenta SU1-Bel.

Posiblemente existen más datos bibliográficos del VSRRP, por ser el representante económicamente más importante de los Arterivirus, donde también se relacionó la apoptosis con la inmunosupresión y el aborto como signos clínicos de la infección viral. Se determinó que el VSRRP replica en el sitio de implantación fetal y causa apoptosis de macrófagos infectados y células adyacentes en la última etapa de gestación (Karniychuk y col., 2011). Más tarde se demostró que el aborto ocurrido durante la infección por este virus, estaba asociado a la infección uterina de VSRRP, donde induce apoptosis a nivel de la interfase materno-fetal, en los tejidos placentarios y endometriales (Novakovic y col., 2017). Otros autores relacionan la inmunodepresión observada en los animales infectados por el VSRRP a la presencia de células apoptóticas en las áreas B y T de los órganos linfoides, sugiriendo que los fenómenos de apoptosis pueden desempeñar un papel en la debilitación de la respuesta inmune del huésped durante la infección viral (Gómez-Laguna 
y col., 2013). Lamentablemente, no existen estudios que relacionen el nivel de apoptosis in vivo con la patogenicidad viral para el caso del VAE.

Los grupos que han estudiado la apoptosis celular in vitro relacionada con el VSRRP tienen opiniones contrarias sobre este proceso. Algunos investigadores, como Miller y Fox (2004) defienden la teoría de que la apoptosis ocurre solamente en las células adyacentes o bystandars, debido a que las células blanco del virus (macrófagos) liberan TNF alfa, y este último sería el responsable de inducir apoptosis en las células vecinas. Sin embargo, otros autores por el contrario sostienen que la apoptosis es inducida por la replicación viral en la célula blanco (Lee y Kleiboeker, 2007; Wang y col., 2015). El estudio más reciente sobre este tema fue realizado por Guo (2018), quien da protagonismo a los nanotubos intercelulares (TNTs), los cuales sirven como una vía alternativa para la propagación del material entre células adyacentes. En este trabajo se encontraron indicios que la infección por el VSRRP podría inducir la formación de TNTs entre las células infectadas y no infectadas. Para ello, co-cultivaron células infectadas con células no infectadas y demostraron que la transferencia de mitocondrias funcionales desde la célula vecina sin parasitar rescató a las células infectadas de la apoptosis en la etapa temprana de infección, a la vez que esta vía de comunicación intercelular permitía la propagación viral. Sería muy interesante contar con estudios de esta complejidad para el caso del VAE. Nuestros resultados consistentemente apoyan la teoría de la relación directa entre patogenicidad de cepa viral y apoptosis evidenciada. Sin embargo, debemos considerar que en otras virosis, como la producida por el Virus de Newcastle es la cepa atenuada MTH-68/H quien causa muerte celular por apoptosis (Fábián y col., 2007), y en el HVE, 
todas las cepas estudiadas hasta el momento, inducen mecanismos antiapoptóticos o de sobrevida (Scrochi y col., 2017).

En el Capítulo 2 se realizó la transfección de construcciones recombinantes con el fin de evaluar la importancia relativa de cada una de las proteínas de mayor importancia, tanto estructural como inmunogénica del VAE, en la apoptosis celular. Tuvimos éxito en la obtención y clonado de 8 de los 9 genes de estudio al vector de expresión seleccionado. Sin embargo la detección de las proteínas sigue siendo un punto crítico para el caso de proteínas del VAE. Los sueros empleados en los WB realizados en este trabajo de tesis provenían del banco de sueros del laboratorio y son de animales vacunados, naturalmente infectados o sueros de referencia frente a la cepa prototipo Bucyrus. Solo empleando este suero de referencia es que se pudo comprobar la correcta expresión del gen gP5 de la cepa Bucyrus. Para las demás proteínas, la secuenciación de los genes clonados demuestra la presencia de las secuencias necesarias para la correcta expresión proteica. Además, la extracción del ARNm de las células transfectadas corroboró la correcta transcripción de cada uno de los genes en estudio. El paso crítico en las construcciones en las cuales no se pudo poner en evidencia la expresión ya sea por SDS PAGE o WB, indefectiblemente se encontraría en el proceso de traducción de cada uno de los transcriptos. Si bien no podemos asegurar cual/cuales fueron los motivos por los que hubo fallas en la traducción normal de proteínas virales del VAE en los cultivos transfectados, según la bibliografía numerosos factores (temperatura, sistema de cultivo, concentración celular previa a la infección, $\mathrm{MOI}$, etc) deben ser considerados para predecir el rendimiento de las proteínas virales in vitro, como fue estudiado en profundidad para la producción a gran escala de 
proteínas y viriones completos de virus oncolíticos con finalidad terapéutica (Grein y col., 2017). Si bien no se encuentran datos disponibles de esta problemática dentro del orden Nidovirales, en el caso del virus de la estomatitis vesicular se observó una baja expresión, lo cual mejoró sustancialmente cuando se añadía Actinomicina D a los cultivos transfectados (Wyers y col., 1980). Otro reporte más reciente sobre fallas en la traducción de proteínas virales es el de Yasmin y col. (2014) donde logran expresar por primera vez niveles aceptables de la proteína nsp3 del virus dengue, cuando los autores relatan que previamente habían encontrado muy bajos rendimientos al transfectar cultivos utilizando el vector pCDNA portando genes para proteínas estructurales de este virus. Factores como el tipo celular y la presencia de inhibidores específicos para el VAE en el vector de expresión seleccionado podrían ser causales del bajo nivel de expresión obtenido. Consideramos que en un futuro podrían clonarse los genes de proteínas del VAE en un vector de expresión que contenga una proteína de fusión como la GFP para poner en evidencia la expresión de las proteinas del VAE en este sistema de transfección eucariota, como fue exitosamente realizado para la el gen de la nsp2 del VSRRP (Wang y col., 2014b) al igual que para la proteína del core del virus de la Hepatitis C (Henao y col., 2004). Nuestros resultados demostraron que las construcciones portando los genes que codifican para las proteínas N, M y gP5 podrían exacerbar la inducción de apoptosis, mostrando los cultivos transfectados con estas construcciones mayores valores de muerte celular con respecto a los cultivos transfectados con el vector vacío. Sin embargo estas consideraciones deberían ser confirmadas por otras experiencias. 
Con respecto a la expresión de la glicoproteína gP5, nuestros resultados muestran que la gP5 de la cepa Bucyrus produjo el mayor porcentaje de apoptosis $(30,4 \%)$, mientras que gP5 de GLAD-LP-ARG indujo un 27,5\% de muerte en cultivos celulares respecto al vector vacío $(20,8 \%)$. El primer estudio sobre el efecto de esta glicoproteína en la apoptosis celular llevado a cabo en Arterivirus fue realizado por Suarez y col. (1996), quienes mediante construcciones recombinantes del virus viruela conteniendo el ORF5 del VSRRP demostraron que esa región es responsable de inducir apoptosis. En este trabajo también se constató que la apoptosis inducida por la gP5 no era inhibida por la proteína antiapoptótica $\mathrm{Bcl}-2$, ya que las transfecciones se llevaron a cabo en células neurales que expresaban Bcl-2 en forma constitutiva (Suarez y col., 1996). Posteriormente, se determinó que la región de la proteína gP5 responsable de inducir apoptosis corresponde a la región citoplasmática de la gP5, por lo tanto se dedujo que existe apoptosis independientemente de la glicosilación de la proteína (Fernández y col., 2002). El estudio original de Suárez también fue validado un año después por Gagnon y col. (2003), quienes demostraron que la expresión de la proteína gP5 del VSRRP en Adenovirus indujo una significativa diferencia positiva en cuanto a la inducción de la apoptosis en relación con el virus original.

Sin embargo, la teoría científicamente aceptada hasta entonces sobre el rol proapoptótico de la gP5 del VSRRP, fue contrariada poco después, cuando un grupo de investigación expresó en forma transiente la proteína gP5 del VSRRP en células HeLa, a las cuales se extrajo el ARNm y se analizó la activación de distintos genes relacionados con la apoptosis por microarrays. Los resultados demostraron una diferencia no significativa con respecto a 
las células transfectadas con el vector vacío (Lee y col., 2004). A pesar de los numerosos intentos, en este trabajo no pudo expresarse la gP5 de la cepa apatógena del VAE LP-01, por lo tanto no pudo relacionarse esta proteína con la apoptosis celular. Podemos intuir que quizás, dado al comportamiento de las construcciones N y M de LP-01, esta cepa sería la que presenta niveles de apoptosis más cercanos a los manifestados por el vector vacío, en relación con su menor patogenicidad in vivo.

Con respecto a la expresión de la proteína de membrana no glicosilada (M), se observó una diferencia despreciable entre el nivel de apoptosis de las cepas más y menos patogénicas (25,7\% en $M$ de Bucyrus y 25,4 en M de LP-01). Sin embargo estos valores difieren considerablemente de los expresados en el vector vacío (20,8\%). Si bien no existen reportes dentro de los Nidovirus, en otras virosis se observó que proteínas de membrana no glicosiladas también inducían apoptosis celular. En el caso del Virus de la estomatitis vesicular (VSV) se responsabilizó a la proteína M de activar la vía intrínseca de apoptosis (Gaddy y col., 2005); mientras que en Flavivirus se descubrió que un péptido derivado de la proteína M permeabiliza directamente la membrana mitocondrial y dispara la apoptosis (Brabant y col., 2009). Si bien no es del todo correcto relacionar proteínas con diferencias nucleotídicas y de distintas familias virales, la escasa bibliografía sobre apoptosis en Nidovirus nos obliga a considerar otras virosis en esta discusión.

Nuestros resultados con respecto a la proteína de la nucleocápside viral $(\mathrm{N})$ también expresan el predominio proapoptótico en la cepa Bucyrus (27,5\%), seguida de GLAD-LPARG (26,5\%), y la inducción de apoptosis más discreta de la cepa apatógena LP-01 (26,1\%). Estos valores, claramente superiores a los expresados por el vector vacío $(20,8 \%)$, colocan 
a la proteína de la nucleocápside en un lugar intermedio entre gP5 (principal proapoptótica) y M (menor inducción de apoptosis) de las tres proteínas del VAE analizadas en este trabajo. En cuanto a la bibliografía previa que relaciona proteínas de la nucleocápside con apoptosis celular, encontramos el estudio realizado en Hantavirus por Li y col. (2002), donde la proteína de la nucleocápside estimularía la apoptosis, mediada por Fas; al igual que la investigación de Siavoshian y col. (2005) donde la proteína del core del Hepatitis C sería responsable del efecto apoptótico. Estos resultados, si bien corresponden a virosis distantes taxonómicamente con el VAE, son similares a los obtenidos en este trabajo. No fue posible comparar nuestros hallazgos con virosis de la misma familia u orden viral debido a la inexistencia de los mismos hasta el momento.

Luego de los resultados obtenidos en este trabajo, y con visión de expandir en un futuro el análisis individual de otras proteínas estructurales y no estructurales del VAE, analizamos la bibliografía existente en Arterivirus y proteínas pro y anti apoptóticas. Una proteína estructural originada del mismo ORF que gP2 es la proteína E la cual fue identificada como proapoptótica en el caso del VSRRP. Un estudio realizado por Pujhari y col. (2016), donde se construyó un plásmido que contenía la proteína E del VSRRP, y GFP como marcador fluorescente, indicó que la proteína E interactúa con proteínas proapoptóticas mitocondriales que llevarían al clivado de la procaspasa 3, desencadenando directamente la vía ejecutora de la apoptosis. Es por ello que la consideraremos como principal candidata en caso de poder continuar con esta línea de investigación.

Existen muchas investigaciones donde se señala a las proteínas no estructurales como responsables de la apoptosis celular. En el caso del VSRRP, el principal trabajo al respecto 
es el de Ma y col. (2013), quienes utilizando construcciones recombinantes que expresaban las proteínas estructurales y no estructurales (nsp) del VSRRP, mediante la técnica de TUNEL, observaron que las únicas proteínas que inducían apoptosis eran las no estructurales 2 y 4 . Recientemente, Yuan y col. (2016) observaron, por un lado, que durante las etapas tempranas de la infección viral se inhibe la apoptosis, y que ésta es estimulada en la etapas tardías (12 hs en PAM y 24 hs en MARC-145). Además, este grupo de investigación realizó construcciones recombinantes con todas las proteínas no estructurales que se transfectaron individualmente, tanto en PAM como en MARC-145 y observaron que la nsp4 inducía activación de las caspasas 8, 9 y 12, e inhibía la proteína antiapoptótica Bcl-XL. Por su parte, la expresión de la nsp10, producía la activación de las caspasas 8 y 9, y de la proteína proapoptótica Bid.

En otras virosis también se observó un efecto proapoptótico marcado en las proteínas no estructurales, siendo la nsp $2 b$ y 3 del virus de la encefalitis japonesa las responsables de inducir apoptosis en células de meduloblastoma (Yang y col., 2009). En tanto, la nsp 3 del virus de la diarrea bovina induciría apoptosis en cultivos celulares a través de la activación de las caspasa 8 y 9 (St-Louis y col., 2005), similar a lo que observaron Ramanathan y col. (2006) con el Virus del Nilo del Oeste, siendo la nsp 3 de este virus suficiente para activar la apoptosis en cultivos celulares.

Existen numerosos estudios que relacionan las proteínas no estructurales del virus de la Hepatitis C con la apoptosis celular. Uno de los primeros trabajos, del 2004, señaló a la nsp3 de este virus como responsable de inducir apoptosis mediante activación de caspasa8 (Prikhod'ko y col., 2004). Posteriormente, Siavoshian y col. (2005) señalaron como 
responsables de inducir apoptosis en células dendríticas maduras a la nsp 3, nsp5a y nsp5b del virus Hepatitis C. Por último, también se determinó que nsp4 de este virus se acumula en la mitocondria y desencadena la vía intrínseca de apoptosis (NomuraTakigawa y col., 2006).

Si bien en nuestras experiencias del Capítulo 2 demostramos inducción de apoptosis en los cultivos transfectados por las proteínas estructurales gP5, $\mathrm{N}$ y $\mathrm{M}$, en ninguno de los casos se observan valores comparables a los observados con el virión completo. Por lo tanto sería interesante plantear la posibilidad de transfectar cultivos con vectores que expresen las proteínas la proteína E y proteínas no estructurales del VAE, para observar si las mismas están implicadas en la apoptosis y en qué medida lo hacen.

En el Capítulo 2 también observamos que la reinfección con el virión completo de la cepa altamente patogénica del VAE (Bucyrus) exacerbaba los valores de apoptosis en todos los cultivos transfectados, los cuales manifestaban un grado basal variable de apoptosis. Esto podría deberse a la sumatoria post infección de elementos virales dentro de las células transfectadas, las cuales se encontraban expresando proteínas virales por un tiempo variable previo a la infección con el virión completo. Nuestros resultados condicen con los obtenidos por Ge y col. (2016), quienes determinaron que las células MARC-145 inducidas a apoptosis son más susceptibles a la infección por una cepa altamente patogénica del VSRRP.

Sin embargo, nuestros hallazgos son opuestos a los observados para el VSRRP, por Gao y col. (2014), quienes disponían de una línea celular MARC-145 que expresaba gP5 en forma estable y observaron que estas células eran refractarias a la infección por el VSRRP. Esto 
ocurría por inducirse la actividad del IFN $\beta$. Estos investigadores pudieron infectar el cultivo solo cuando previamente bloquearon la acción del IFN $\beta$, utilizando un ARN silente. Por lo tanto, se pudo demostrar una relación entre la expresión de esta proteína viral (gP5 del VSRRP) y la permisibilidad de infección por el virión completo.

En el Capítulo 2 se demostró que el tratamiento con STS exacerbó los valores de apoptosis en los cultivos transfectados, con excepción de las construcciones que portaban el gen M de las distintas cepas del VAE. Esta exacerbación de los niveles de apoptosis observados en los cultivos transfectados podría deberse a la sumatoria de las distintas vías apoptóticas activadas: las propias de cada cepa viral (iniciadas por las caspasa-8, -9, -12 y 3), siendo potenciadas por la activación de la caspasa-3 inducida al incorporar este compuesto químico al medio de cultivo. Sin embargo, en el VSRRP se demostró que las células MARC-145 expresando gP2 del VSRRP en forma estable e inducidas con STS manifestaron 8 veces menos apoptosis que las células transfectadas con el vector vacío (Pujhari y col., 2014), revelando un posible rol antiapoptótico de la proteína de envoltura gP2 del VSRRP. Otro estudio con el VSRRP, donde macrófagos infectados fueron tratados con STS a las 4, 5, 6 y 8 hpi resultaron ser refractarios a la apoptosis inducida por la STS. Sin embargo, cuando los macrófagos infectados se trataban con STS a las 12 hpi, ya no eran protegidos y sufrieron apoptosis dependiente de caspasas, que culminó en necrosis secundaria (Costers y col., 2008). Este último resultado también demostraría una acción antiapoptótica viral en el VSRRP en las primeras hpi al igual que la proteína M en nuestro trabajo. 
En el caso del virus de Varicella-Zoster, células transfectadas con el producto del ORF63 demostró proteger a células neuronales maduras de la apoptosis inducida por STS. (Gerada y col., 2018). En nuestras experiencias todas las células transfectadas manifestaron cuantitativamente más apoptosis una vez inducidas por STS.

Una consideración especial debemos hacer respecto a los anticuerpos anti-caspasas que utilizamos en nuestro trabajo. Los mismos fueron adquiridos al distribuidor en Argentina, seleccionados para ser utilizados en un amplio rango de especies y para distintas técnicas. Fueron seleccionados 3 que llegaron en condiciones de adecuadas al laboratorio y conservadas en frío hasta el momento de su uso. En las primeras experiencias por WB utilizando la concentración indicada por el fabricante, y utilizando un control positivo notamos que no era posible obtener bandas $y$ en las experiencias siguientes concentramos notablemente los mismos con idénticos resultados. Ello nos llevó a realizar las experiencias con mínimos volúmenes utilizando células transfectadas crecidas en cubreobjetos. Si bien podemos señalar que la expresión utilizando pcDNA no fue la esperada, también hacemos notar que el rendimiento de los anticuerpos anti-caspasas fue muy pobre. Realizando una búsqueda en el catálogo original de la empresa, encontramos que los 3 anticuerpos que fueron adquiridos 2 años antes, habían sido retirados de la venta. Esto podría deberse a que los anticuerpos fallaban en las reacciones, y probabablemente, otros autores hayan reclamado al fabricante.

En el Capítulo 3 se demostró que la muerte celular observada en los cultivos infectados con el VAE es apoptosis celular sin participación notable de otras vías de muerte celular, demostrándose esto mediante el uso de inhibidores de apoptosis, necrosis y autofagia. Sin 
embargo, en estudios con el VSRRP se observó que induce tanto autofagia como apoptosis (Li, 2016). En esta virosis, cuando se produjo la inhibición de la autofagia por 3-MA se observó un aumento significativo en la apoptosis inducida por el VSRRP, mostrando una relación potencial entre ambos mecanismos (Zhou y col., 2016). También en este arterivirus se demostró recientemente que la infección viral estimularía la fusión mitocondrial y la mitofagia (un tipo de autofagia) durante la replicación viral (Li, 2016).

En el Capítulo 3 también se demostró la importancia de la vía del retículo endoplásmico, representada por la caspasa 12 , siendo una de las principales rutas apoptóticas activadas por el VAE. En el caso de los Arterivirus, los primeros reportes que indicaron la activación de esta vía fueron, para el caso del VAE el trabajo de Metz y col. (2016), donde se detectó la activación de la caspasa-12; y en el VSRRP fue el estudio de Wang y col. (2014a) donde además se determinó que la proteína nsp 2 del VSRRP es transportada al RE e iniciaría apoptosis por esa vía.

La activación de esta vía de apoptosis fue objeto de estudio de numerosas virosis recientemente, si bien las publicaciones, con excepción de las nombradas previamente, no pertenecen a la familia o al orden viral del VAE. Uno de los primeros trabajos determinó que el virus de la diarrea bovina induce la respuesta de estrés del RE vía caspasa 12 (Jordan y col., 2002) opuesto a lo que ocurre con el virus de la Hepatitis C, quien suprime la vía del RE, contribuyendo a su persistencia en los hepatocitos infectados (Tardif y col., 2004). Posteriormente la bibliografía sobre el tema se amplió con el trabajo de Li (2005), demostrando que el Tula hantavirus desencadenaba la vía apoptótica del RE en células Vero E6; el trabajo de Yu y col. (2006) donde observaron que la infección por 
Flavivirus activaba la vía del RE y en 2007, Umareddy y col., quienes demostraron que el virus Dengue también activaba esta vía.

En los últimos anos, se descubrió que múltiples virosis debían sumarse a las que inducían apoptosis a través del estrés del RE: el Virus Nilo del Oeste (Wang y col., 2010), el Coxsackievirus (Zhang y col., 2010), el Semliki Forest virus (Barry y col., 2010), el Virus de Influenza A (Roberson y col., 2012), entre otros.

En algunos casos se relacionó el pasaje viral a través del RE con el estrés de esta organela. En la investigación de Galindo y col. (2012) con el virus fiebre Africana del simio, de demostró que este virus utiliza el RE como sitio de replicación y este proceso desencadena el estrés en la célula huésped.

En animales de laboratorio se relacionó la vía de apoptosis iniciada por la caspasa-12 con la patogenia de algunas deficiencias hormonales, como el caso del virus Kilham de la rata. En esta virosis, la vía de estrés del RE inducida por el VKR produce la muerte de las células $\beta$ del páncreas, lo que lleva a diabetes inducida por virus (Yang y col., 2013).

Estos datos señalan la importancia de esta vía "no convencional" de apoptosis, y fue por ello considerada para ser estudiada cuando tuve la posibilidad de trabajar con inhibidores durante mi estancia en el exterior.

Este trabajo de investigación se logró la construcción de 8 vectores recombinantes conteniendo genes del VAE, en los cuales se investigó la importancia de cada uno de ellos en el desarrollo de la apoptosis celulares en los cultivos celulares transfectados. 
Nuestro trabajo puso en evidencia los efectos proapoptóticos de las proteínas expresadas, en concordancia con lo reportado previamente donde se encontró inducción de apoptosis por parte de la proteína gP5 en células de insectos (Metz y col, 2014).

Nuestros hallazgos de efectos proapoptóticos por parte de las otras proteínas recombinantes empleadas en este trabajo, requieren mayores análisis respecto de a donde se produce la interacción de dichas proteínas en el proceso de apoptosis celulares. Analizar con más detalle con que vía o vías de la apoptosis celulares interactuarían cada una de las proteínas estudiadas, además de estudiar si el efecto es debido a una región particular de las proteínas expresadas. Por ejemplo en el VSRRP se determinó que la región de la proteína gP5 responsable de la inducción de la apoptosis está comprendida entre N119 y C90 encontrándose ésta región en la cara citoplasmática de la gP5, permitiéndonos deducir que la apoptosis ocurre independientemente de la glicosilación proteica (Fernández y col., 2002). En esta misma virosis porcina, la proteína de membrana E fue relacionada con la apoptosis mitocondrial o vía intrínseca (Pujhari y col., 2016), mientras que la nsp4 demostró activar las distintas vías apoptóticas: extrínseca, intrínseca y del retículo (Yuan y col., 2016). Considerando lo observado en el VSRRP, quedaría analizar si las proteínas no estructurales del VAE y la proteína estructural E participan de alguna manera en el proceso apoptótico por parte del virión maduro.

La compresión de que proteínas y como es su interacción con el proceso de apoptosis, permitirá comprender los mecanismos de apoptosis desarrollados por el virus y relacionarlos con el proceso de patogenicidad en un animal in vivo. Recordemos que el virus de arteritis está caracterizado por la lisis de las pequeñas arteriolas de los animales 
infectados, proceso en el cual la apoptosis podría ser un desencadenante protagónico de este mecanismo de daño del virus en infecciones in vivo. Considero humildemente que los resultados obtenidos en este trabajo de tesis doctoral permitirán en un futuro perfeccionar el diagnóstico in vitro de esta virosis, acortando los tiempos requeridos para ello, mediante la puesta a punto de otras herramientas de detección de la actividad viral en la célula huésped como por ejemplo qPCR para la detección de distintas caspasas virales o multilplex PCR luego de 12 hs pi, o bien WB con lisados celulares infectados. La participación en la muerte celular de los distintos genes virales evaluados y por evaluar, abren nuevos interrogantes destinados a comprender en mayor profundidad la patogenia de enfermedad, con la esperanza de potenciar las herramientas de prevención, diagnósticas y terapéuticas disponibles actualmente. 


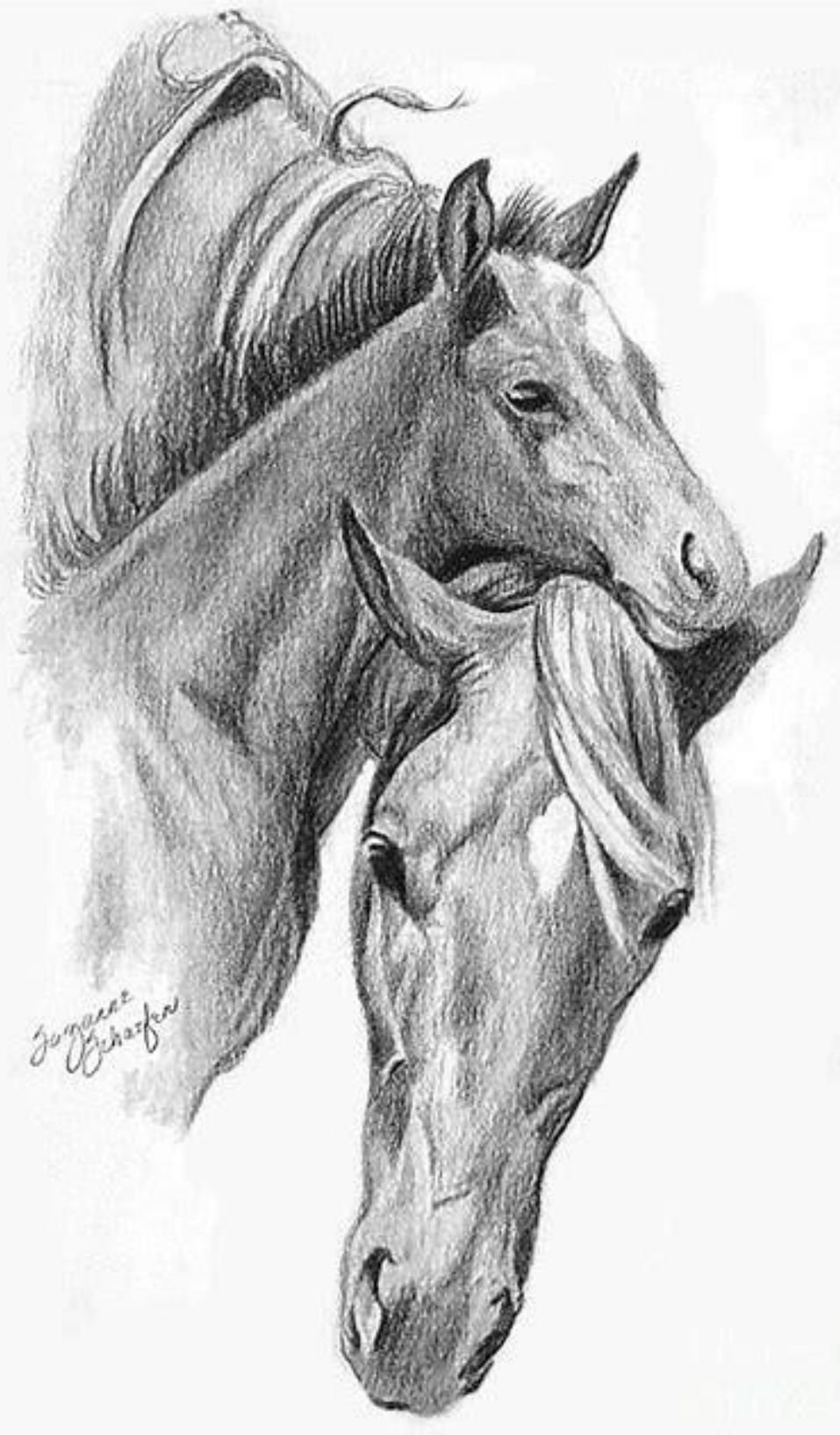

\section{Anexo: Secuencias}


>gen gP5-cepaBUCYRUS

TGGGCTCAACGATGTTATCTATGATTGTATTGCTATTCTTGCTTTGGGGTGCGCCATCACATGCTTA CTTCTCATACTACACCGCTCAGCGCTTCACAGACTTCACCTTGTGTATGCTGACGGATCGCGGCGTT ATTGCCAATTTGCTGCGATATGATGAGCACATGTACAATTGTTCCGCCAGTAAAACCTGTTGGTAT TGCACATTCCTGGACGAACAGGTTATCACGATTGGAACCGATTGTAATAACGCCCACGCGGTCTCA GTTGCTGAGGTCCTGGAACAGGCGCATGGACCGTACAGTGTGCTGTTTGATGACATGCCCCCTTTT ATTTACTATGGCCGTGAGTTCGGCATAGTTGTGTTCGATGTGTTTATGTTCTATCCCGTTTTAGTTC TGTTTTTCTTATCAGTACTACCCTATGCTACGCTTATTCTTGAAATGTGTGTATCTATTCTGTTTATA ATCTATGGCATTTACAGCGGGGCCTACTTGGCCATGGGCATATTTGCGGCCACGCTTGCTATACAT TCAATTGTGGTCCTCCGCCAATTACTGTGGTTATGCCTGGCTTGGCGATACCGCTGTACGCTTCAC GCGTCCTTTATATCAGCTGAGGGGAAAGTGTACCCCGTAGACCCCGGACTCCCGGTTGCCGCCGC GGGCAATCGGTTGTTAGTCCCAGGTAGGCCCACTATCGATTATGCAGTGGCCTACGGCAGCAAAG TCAACCTTGTGAGGTTGGGGGCAGCTGAGGTATGGGAGCCATAG

>gen gP5-cepaGLD-LP-ARG

TGGGCTCAACGATGTTATCTATGATTGTATTGCTGTTTTTGCTTTGGGGTGTGCCATCACATGCTTA CTTCTCATATTACACCGCTCAGCGCTTTACAGACTTCACCTTGTGTATGCTGACGGATCGCGGCGTT ATTGCCAATTTGCTGCGGTATGATGAGCACACTGCCCTGTACAATTGCTCCGCCAGCAAAACCTGC TGGTATTGCGAGTTCTTGAACGAACAGATCATCACATTTGGGACTGGCTGTAATGACACCTACTCT GTCCCAGTTTCCACAGTTTTGGAGCAGGCTCATGGGCCGTACAGTGTGCTGTTTGATGACATGCCC CCTTTCATTTACTATGGCCGTGAGTTTGGCATATTTGTGATGGATGTGGTTATGTTTTATCCAGTTT TAGTTTTGTTTTTCTTGTCAGTATTGCCTTATGCCACACTTATTCTTGAGATGTGTGTGTCTATTTTG TTTGTGGTCTATGGCCTTTACAGTGGAGCTTATTTAGCCATGGGAATATTTGCGACCACGCTCGTT GTACATTCAGTTGTGGTCCTCCGCCAATTGCTGTGGTTGTGCCTGGCCTGGCGGTATCGCTGCACG CTCCACGCGTCCTTTATATCAGCTGAGGGGAAAATTTACCCCGTAGACCCCGGACTCCCAATTGCC GCTGCTGGCAATCGGTTGTTAGTTCCAGGTAGGCCCACCATTGATTACGCGGTGGCCTACGGCAG CAAGGTCAACCTTGTGAGGTTAGGGGCAGCTGAAGTATGGGAGCCATAG 
SECUENCIAS M NUCLEOTIDOS

>genM-cepaBUCYRUS

GAGCTCGGATCCAGGTATGGGAGCCATAGATTCATTTTGTGGTGACGGGATTTTAGGTGAGTATC TAGATTACTTTATTCTGTCCGTCCCACTCTTGCTGTTGCTTACTAGGTATGTAGCATCTGGGTTAGT GTATGTTTTGGCTGCCTTGTTCTATTCCTTTGTATTAGCAGCTTATATTTGGTTTGTTATAGTTGGAA GAGCCTTTTCTACTGCTTATGCTTTTGTGCTTTTGGCTGCTTTTCTGTTATTAGTAATGAGGATGATT GTAGGTATGATGCCTCGTCTTCGGTCCATTTTCAACCATCGCCAACTGGTGGTAGCTGATTTTGTG GACACACCTAGTGGACCTGTTCCCATCCCCCGCTCAACTACTCAGATAGTGGTTCGCGGCAACGGG TACACCGCAGTTGGTAACAAGCTTGTCGATGGCGTCAAGACGATCACGTCCGCAGGCCGCCTCTTT TCGAAACGGGCGCCGGCGACAGCCTACAAGCTACAATGACCTACTGCTCGAGCATGCATCTAGAG GGCCCTATTCTATAGTGTCACCTAAATGCTAGAG

>genM-cepaLP01

GGATCCAGGTATGGGAGCCATAGATTCATTTTGTGGTGACGGGATTTTAGGTGAGTATCTAGATT ACTTTATTCTGTCCGTCCCACTCTTGCTGTTGCTTACTAGGTATGTAGCATCTGGGTTAGTGTATGT TTTGGCTGCCTTGTTCTATTCCTTTGTATTAGCAGCTTATATTTGGTTTGTTATAGTTGGAAGGGCCT TTTCTACTGCTTATGCTTTTGTGCTTTTGGCTGCTTTTCTGTTATTAGTAATGAGGATGATTGTAGGT ATGATGCCTCGCCTTCGGTCCATTTTCAACCATCGCCAACTGGTGGTAGCTGATTTTGTGGACACA CCTAGTGGACCTGTTCCCATCCCCCGCTCAACTACTCAGATAGTGGTTCGCGGCAACGGGTACACC GCAGTTGGTAACAAGCTTGTCGATGGCGTCAAGACGATCACGTCCGCAGGCCGCCTCTTTCCGAA

ACGGGCGGCGGCGACAGCCTACAAGCTACAATGA

>genM-cepaGLD-LP-ARG

GGATCCAGGTATGGGAGCCATAGATTCGTTTTGTGGTGACGGGATTTTAGGTGAATATCTAGATT ATTTTATTCTGTCCGTCCCACTTTTGTTGCTAATTACTAGGTATGTGGCATCTGGATTGGTATACGT GATGACTGCTTTGTTTTATTCCTTTGTGTTAGCAGCTTATATTTGGTTTGTTATAGTTGGAAGGGCT TTTTCCACTGCCTATGCTTTTGTGTTACTGGCTGCTTTTCTGCTATTATTAATAAGAATGATTGTAGG TGTGTTGCCTCGTCTTCGGTCCATTTGTAATCACCGCCAGCTGGTGGTAGCTGATTTTGTGGACAC ACCCAGTGGACCCGTTCCCATCCCCCGTTCAACTACTCAGGTAGTGGTCCGCGGCAACGGGTACAC AGCAGTTGGTAACAAGCTTGTCGATGGCGTCAAGACGATCACGTCCGCAGGCCGCCTCTTTTCGA AACGGACGACGGCGACAGCCTACAAGCTACAATGACCTACTGCTCGAG 
SECUENCIAS N NUCLEOTIDOS

>genN-cepaBUCYRUS

TAGGATCCAGCTTGACGATGGCGTCAAGACGATCACGTCCGCAGGCCGCCTCTTTTCGAAACGGG CGGCGGCGACAGCCTACAAGCTGCAATGACCTACTGCGTATGTTTGGTCAGATGCGGGTCCGCAA ACCGCCCGCGCAACCCACTCAGGCTATCATTGCAGAGCCTGGAGACCTTAGGCATGATTTAAATCA ACAGGAGCGCGCCACCCTTTCGTCGAACGTACAACGGTTCTTCATGATTGGGCATGGTTCACTCAC TGCAGATGCCGGAGGACTCACGTACACCGTCAGTTGGGTTCCTACCAAACAAATCCAGCGCAAAG TTGCGCCTCCAGCAGGGCCGTAA

>genN-cepaLP01

TAGGATCCAGCTTGACGATGGCGTCAAGACGATCACGTCCGCAGGCCGCCTCTTTTCGAAACGGA CGGCGGCGACAGCCTACAAGCTACAATGACCTACTGCGTATGTTTGGTCAGATGCGGGTCCGCAA ACCGCCCGCGCAACCCACTCAGGCTATCATTGCAGAGCCTGGAGACCTCAGGCATGAGTTAAATC AGCAGGAGCGCGCCACCCTGTCGTCGAACGTACAGCGATTCTTTATGATAGGGCACGGTTCACTC ACTGCAGATGCCGGAGGACTCACGTACACCGTCAGTTGGGTTCCTACCAAACAAATTCAGCGCAA AGTTGCGCCTTCAGCAGGGCCGTAA

>genN-cepaGLD-LP-ARG

TAGGATCCAGCTTGACGATGGCGTCAAGACGATCACGTCCGCAGGCCGCCTCTTTTCGAAACGGA CGACGGCGACAGCCTACAAGCTACAATGACCTACTGCGTATGTTTGGTCAGATGCGGGTCCGCAA ACCGCCCGCACAACCCACTCAGGCTATCATTGCAGAGCCTGGAGATCTCAGGCATGAGTTAAATC AGCAGGAGCGCGCCACCCTGTCGTCGAACGTGCAGCGGTTCTTTATGATAGGGCACGGTTCACTC ACTGCAGATGCCGGAGGACTCACGTACACCGTCAGTTGGGTTCCTACCAAACAAATTCAGCGCAA AGTCGCGCCTTCAGCAGGGCCGTAA

Se marcan en cada secuencia los codones de inicio y de stop en recuadro, mientras que en amarillo se marcan las bases consenso necesarias de la secuencia kozak. 


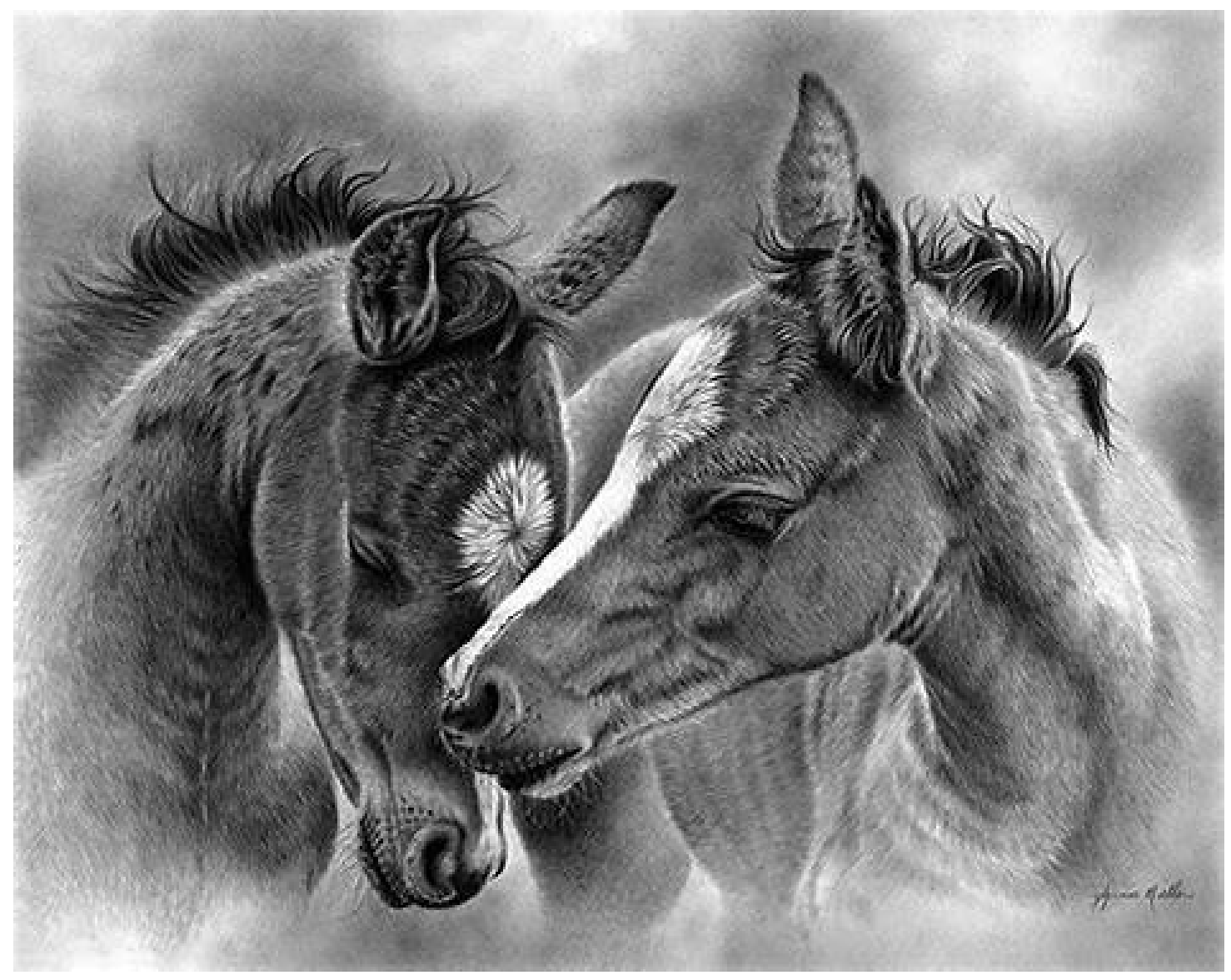

\section{Conclusiones}


- La magnitud de muerte celular observada en los cultivos celulares infectados está directamente relacionada con: la patogenicidad de la cepa viral del VAE, la MOI utilizada y el tiempo pi (Capítulo 1).

- La línea celular RK-13 es la que sufre en mayor medida, y de forma más temprana, apoptosis celular tras la infección por el VAE (Capítulo 1).

- La expresión de las proteínas N, M y gP5 exacerban la inducción de apoptosis mostrando los cultivos transfectados con estas construcciones mayores valores de muerte celular con respecto a los cultivos que expresan el vector vacío (Capítulo 2). Sin embargo, en ninguno de los casos se observan valores comparables a los observados con el virión completo (Capítulo 1).

- La reinfección con el virión completo de una cepa altamente patogénica del VAE exacerba los valores de apoptosis en los cultivos transfectados (Capítulo 2).

- El tratamiento con STS exacerba los valores de apoptosis en los cultivos transfectados, con excepción de las construcciones portando el gen $M$ de las distintas cepas del VAE (Capítulo 2).

- La vía del RE, representada por la caspasa 12 , es una de las principales rutas apoptóticas activadas por el VAE (Capítulo 3).

- La muerte celular observada en los cultivos infectados con el VAE es principalmente apoptosis, demostrándose esto mediante el uso de inhibidores de apoptosis, necrosis y autofagia (Capítulo 3). 


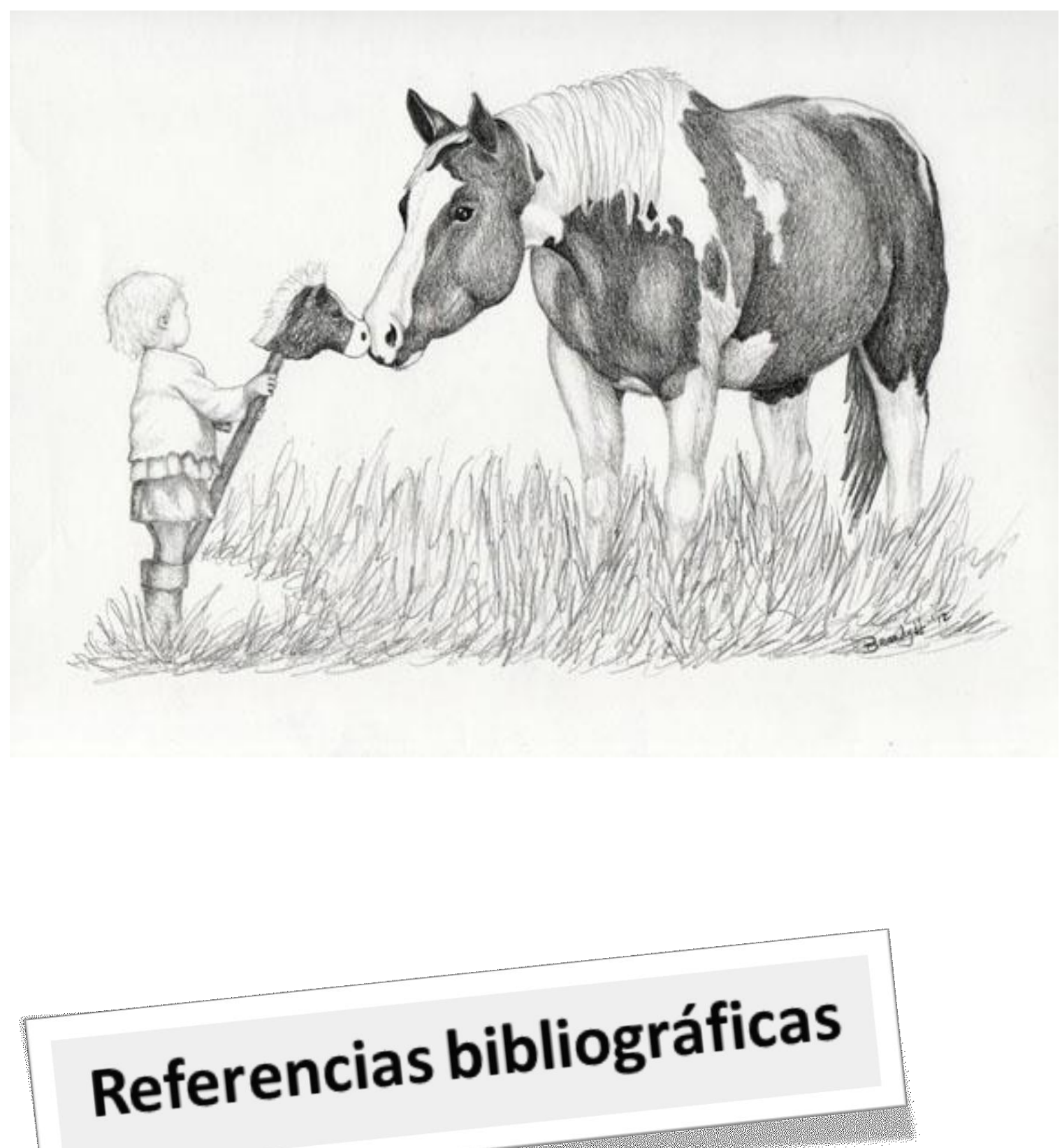


1. Albright-Fraser DG. 1998. Studies on the organization and polymorphism of equine MHC Class II genes. Ph.D. dissertation, University of Kentucky.

2. Amarilla SP, Gómez-Laguna J, Carrasco L, Rodríguez-Gómez IM, Caridad Y Ocerín JM, Graham SP, Frossard JP, Steinbach F, Salguero FJ. 2016. Thymic depletion of lymphocytes is associated with the virulence of PRRSV-1 strains. Veterinary Microbiology. 188:47-58. doi: 10.1016/j.vetmic.2016.04.005.

3. Archambault D, St-Laurent G. 2000. Induction of apoptosis by equine arteritis virus infection. Virus Genes 20: 143-147.

4. Arur S, Uche UE, Rezaul K, Fong M, Scranton V, Cowan AE, Mohler W, Han DK. 2003. Annexin $I$ is an endogenous ligand that mediates apoptotic cell engulfment. Developmental Cell. 4:587-598. doi: 10.1016/S1534-5807(03)00090-X.

5. Asagoe T, Inaba Y, Jusa ER, Kouno M, Uwatoko K, Fukunaga Y. 1997. Effect of heparin on infection of cells by equine arteritis virus. Journal of Veterinary Medical Science. 59:727728. doi: 10.1292/jvms.59.727.

6. Ashkenazi A, Dixit VM. 1998. Death receptors: signaling and modulation. Science. 281:1305-1308. doi: 10.1126/science.281.5381.1305.

7. Balasuriya UB, Rossitto PV, DeMaula CD, MacLachlan NJ. 1993. A 29K envelope glycoprotein of equine arteritis virus expresses neutralization determinants recognized by murine monoclonal antibodies. Journal of General Virology. 74:2525-2529. doi: 10.1099/0022-1317-74-11-2525

8. Balasuriya UB, Timoney PJ, McCollum WH, MacLachlan NJ. 1995a. Phylogenetic analysis of open reading frame 5 of field isolates of equine arteritis virus and identification of conserved and non-conserved regions in the GL envelope glycoprotein. Virology. 214:690697. doi: $10.1006 /$ viro.1995.0087

9. Balasuriya UB, Maclachlan NJ, De Vries AA, Rossitto PV, Rottier PJ. 1995b. Identification of a neutralization site in the major envelope glycoprotein (GL) of equine arteritis virus. Virology. 207:518-527. doi: 10.1006/viro.1995.1112

10. Balasuriya UB, Patton JF, Rossitto PV, Timoney PJ, McCollum WH, MacLachlan NJ. 1997. Neutralization determinants of laboratory strains and field isolates of equine arteritis virus: identification of four neutralization sites in the amino-terminal ectodomain of the $G$ (L) envelope glycoprotein. Virology. 232:114-128. doi: 10.1006/viro.1997.8551 
11. Balasuriya UB, Evermann JF, Hedges JF, McKeirnan AJ, Mitten JQ, Beyer JC, McCollum WH, Timoney PJ, MacLachlan NJ. 1998. Serologic and molecular characterization of an abortigenic strain of equine arteritis virus isolated from infective frozen semen and an aborted equine fetus. Journal of the American Veterinary Medical Association. 213:15861589.

12. Balasuriya UB, Hedges JF, Nadler SA, McCollum WH, Timoney PJ, MacLachlan NJ. 1999. Genetic stability of equine arteritis virus during horizontal and vertical transmission in an outbreak of equine viral arteritis. Journal of General Virology. 80:1949-1958. doi: 10.1099/0022-1317-80-8-1949.

13. Balasuriya U, Heidner W, Hedges J, Williams J, Davis L, Johnston R, MacLachlan N. J. 2000. Expression of the two major envelope proteins of equine arteritis virus as a heterodimer is necessary for induction of neutralizing antibodies in mice immunized with recombinant Venezuelan equine encephalitis virus replicon particles. Virology. 74:10623-10630. doi: 10.1128/JVI.74.22.10623-10630.2000.

14. Balasuriya UB, MacLachlan NJ. 2004. The immune response to equine arteritis virus: potential lessons for other arteriviruses. Veterinary Immunology and Immunopathology. 102:107-129. doi: 10.1016/j.vetimm.2004.09.003.

15. Balasuriya UB, Hedges JF, Smalley VL, Navarrette A, McCollum WH, Timoney PJ, Snijder EJ, MacLachlan NJ. 2004a. Genetic characterization of equine arteritis virus during persistent infection of stallions. Journal of General Virology. 85:379-390. doi: 10.1099/vir.0.19545-0.

16. Balasuriya UB, Dobbe JC, Heidner HW, Smalley VL, Navarrette A, Snijder EJ, MacLachlan NJ. 2004b. Characterization of the neutralization determinants of equine arteritis virus using recombinant chimeric viruses and site-specific mutagenesis of an infectious cDNA clone. Virology. 321:235-246. doi: 10.1016/j.virol.2003.12.015.

17. Balasuriya UB, Go Y, Mac Lachlan NJ. 2013. Equine arteritis virus. Veterinary Microbiology. 167:93-122. doi: 10.1016/j.vetmic.2013.06.015

18. Barry G, Fragkoudis R, Ferguson MC, Lulla A, Merits A, Kohl A, Fazakerley JK. 2010. Semliki forest virus-induced endoplasmic reticulum stress accelerates apoptotic death of mammalian cells. Journal of Virology. 84(14):7369-77. doi: 10.1128/JVI.02310-09.

19. Bergman AM. 1913. Beiträge zur Kenntnis der Virustrager bei Rotlaufseuche, Influenza erysipelatosa, des Pferdes. Z Infektionskrankh. 13:161-174. 
20. Borchers K, Wiik H, Frolich K, Ludwig H, East ML. 2005. Antibodies against equine herpesviruses and equine arteritis virus in Burchell's zebras (Equus burchelli) from the Serengeti ecosystem. Journal of Wildlife Diseases. 41:80-86. doi: 10.7589/0090-355841.1.80.

21. Bortner CD, Oldenburg NB, Cidlowski JA. 1995. The role of DNA fragmentation in apoptosis. Trends in Cell Biology. 5:21-26. doi: 10.1016/S0962-8924(00)88932-1.

22. Brabant M, Baux L, Casimir R, Briand JP, Chaloin O, Porceddu M, Buron N, Chauvier D, Lassalle M, Lecoeur H, Langonné A, Dupont S, Déas O, Brenner C, Rebouillat D, Muller S, Borgne-Sanchez A, Jacotot E. 2009. A flavivirus protein M-derived peptide directly permeabilizes mitochondrial membranes, triggers cell death and reduces human tumor growth in nude mice. Apoptosis. 14(10):1190-1203. doi: 10.1007/s10495-009-0394-y.

23. Bratton DL, Fadok VA, Richter DA, Kailey JM, Guthrie LA, Henson PM. 1997. Appearance of phosphatidylserine on apoptotic cells requires calcium-mediated nonspecific flip-flop and is enhanced by loss of the aminophospholipid translocase. Journal of Biological Chemistry. 272:26159-26165. doi: 10.1074/jbc.272.42.26159.

24. Broaddus CC, Balasuriya UB, Timoney PJ, White JL, Makloski C, Torrisi K, Payton M, Holyoak GR. 2011. Infection of embryos following insemination of donor mares with equine arteritis virus infective semen. Theriogenology 76:47-60. doi: 10.1016/j.theriogenology.2011.01.017.

25. Bürki F, Gerber H. 1966. Ein virologisch gesicherter Grossansbruck von equiner Arteritis. Berl. Münch Tierär Woch. 79:391-395.

26. Cai J, Yang J, Jones DP. 1998. Mitochondrial control of apoptosis: the role of cytochrome c. Biochimica et Biophysica Acta. 1366(1-2):139-149. doi: 10.1016/S0005-2728(98)00109-1.

27. Carossino M, Loynachan AT, Canisso IF, Cook RF, Campos JR, Nam B, Go YY, Squires EL, Troedsson MHT, Swerczek T, Del Piero F, Bailey E, Timoney PJ, Balasuriya UBR. 2017. Equine arteritis virus has specific tropism for stromal cells and CD8+ T and CD21+ B lymphocytes but not for glandular epithelium at the primary site of persistent infection in the stallion reproductive tract. Journal of Virology. 91:418-417. doi: 10.1128/JVI.00418-17.

28. Castillo-Olivares J, Tearle JP, Montesso F, Westcott D, Kydd JH, Davis-Poynter NJ, Hannant D. 2003. Detection of equine arteritis virus (EAV)-specific cytotoxic CD8+ T lymphocyte precursors from EAV-infected ponies. Journal of General Virology. 84:2745-2753. doi: 10.1099/vir.0.19144-0. 
29. Cavanagh D. 1997. Nidovirales: a new order comprising Coronaviridae and Arteriviridae. Archives of Virology. 142:629-633.

30. Chenchev I. 2008. Studies on the equine viral arteritis situation in Bulgaria. Second international workshop on equine arteritis virus, Lexington, Kentucky. 30-31.

31. Chicheportiche Y, Bourdon PR, Xu H, Hsu YM, Scott H, Hession C, Garcia I, Browning JL. 1997. TWEAK, a new secreted ligand in the tumor necrosis factor family that weakly induces apoptosis. Journal of Biological Chemistry. 272:32401-32410. doi: 10.1074/jbc.274.13.8455.

32. Chinnaiyan AM. 1999. The apoptosome: heart and soul of the cell death machine. Neoplasia. 1:5-15.

33. Chirnside ED. 1992. Equine arteritis virus: An overview. British Veterinary Journal. 148:181-197. doi: 10.1016/0007-1935(92)90044-2.

34. Chirnside ED, Wearing CM, Binns MM, Mumford JA. 1994. Comparison of $M$ and $N$ gene sequences distinguishes variation amongst equine arteritis virus isolates. Journal of General Virology. 75:1491-1497. doi: 10.1099/0022-1317-75-6-1491.

35. Cho HJ, Entz SC, Deregt D, Jordan LT, Timoney PJ, McCollum WH. 2000. Detection of antibodies to equine arteritis virus by a monoclonal antibody-based blocking ELISA. Canadian Journal of Veterinary Research. 64:38-43.

36. Cholleti H, Paidikondala M, Munir M, Hakhverdyan M, Baule C. 2013. Equine arteritis virus induced cell death is associated with activation of the intrinsic apoptotic signalling pathway. Virus Research. 171:222-226. doi: 10.1016/j.virusres.2012.10.004.

37. Cohen JJ. Programmed cell death in the immune system. Advances in Immunology. 1991;50:55-85.

38. Coignoul FL, Cheville NF. 1984. Pathology of maternal genital tract, placenta and fetus in equine viral arteritis. Veterinary Pathology. 21:333-340. doi: 10.1177/030098588402100311.

39. Cole JR, Hall RF, Gosser HS, Hendricks JB, Pursell AR, Senne DA, Pearson JE, Gipson CA. 1986. Transmissibility and abortogenic effect of equine viral arteritis in mares. Journal of the American Veterinary Medical Association. 189:769-771.

40. Cooper GM, Hausman RE. 2009. Cell death and cell renewal. In the cell: A molecular approach. Sinauer Associates, Inc. Sunderland, Massachusetts. 693-722. 
41. Cory S, Adams JM. 2002. The Bcl2 family: regulators of the cellular life-or-death switch. Nature Reviews Cancer Journal. 2:647-56. doi: 10.1038/nrc883.

42. Costers S, Lefebvre D, Delputte $P$, Nauwynck H. 2008. Porcine reproductive and respiratory syndrome virus modulates apoptosis during replication in alveolar macrophages. Archives of Virology. 153(8):1453-1465. doi: 10.1007/s00705-008-0135-5.

43. Crawford TB, Henson JB. 1972. Immunofluorescent, light-microscopic and immunologic studies of equine arteritis. In: Proceedings of International Conferences Equine Infectious Diseases. 3:282-302.

44. Debnath J, Baehrecke EH, Kroemer G. 2005. Does autophagy contribute to cell death? Autophagy. 1:66-74. doi: 10.4161/auto.1.2.1738.

45. de Groot RJ, Cowley JA, Enjuanes L, Faaberg KS, Perlman S, Rottier PJ, Snijder EJ, Ziebuhr J, Gorbalenya AE. 2012. Order Nidovirales. In: Virus taxonomy. Ninth report of the international committee on taxonomy of viruses. Elsevier Academic Press, Amsterdam. 785-795.

46. de la Sota MD, Gonzalez R, Chiricosta A. 2005. Situación de la arteritis viral equina en la Argentina. Suplemento técnico veterinario de la Revista del Colegio de Veterinarios de la Provincia de Buenos Aires. 33:44-48.

47. den Boon JA, Snijder EJ, Chirnside ED, de Vries AA, Horzinek MC, Spaan WJ. 1991. Equine arteritis virus is not a togavirus but belongs to the coronavirus-like superfamily. Journal of Virology. 65:2910-2920.

48. den Boon JA, Spaan WJ, Snijder EJ. 1995. Equine arteritis virus subgenomic RNA transcription: UV inactivation and translation inhibition studies. Virology. 213:364-372. doi: 10.1006/viro.1995.0009.

49. den Boon JA, Kleijnen MF, Spaan WJ, Snijder EJ. 1996. Equine arteritis virus subgenomic mRNA synthesis: analysis of leader-body junctions and replicative-form RNAs. Journal of Virology. 70:4291-4298.

50. Denecker G, Vercammen D, Declercq W, Vandenabeele P. 2001. Apoptotic and necrotic cell death induced by death domain receptors. Cellular and Molecular Life Sciences. 58:356-370. doi: 10.1007/PL00000863.

51. Del Piero F, Wilkins PA, Lopez JW, Glaser AL, Dubovi EJ, Schlafer DH, Lein DH. 1997. Equine viral arteritis in newborn foals: clinical, pathological, serological, microbiological and 
immunohistochemical observations. Equine Veterinary Journal. 29:178-185. doi: 10.1111/j.2042-3306.1997.tb01666.x.

52. Del Piero F. 2000. Equine viral arteritis. Veterinary Pathology. 37:287-296. doi: 10.1354/vp.37-4-287.

53. Del Piero F. 2006. Equine viral arteritis: Signs, lesions, pathogenesis and diagnoses. In Proceedings of the Annual Meeting of the American College of Veterinary Pathologists and American Society for Veterinary Clinical Pathology, Tucson, Arizona.

54. Delputte PL, Vanderheijden N, Nauwynck HJ, Pensaert MB. 2002. Involvement of the matrix protein in attachment of porcine reproductive and respiratory syndrome virus to a heparin-like receptor on porcine alveolar macrophages. Journal of Virology. 76:4312-4320. doi: $10.1128 / J V I .76 .9 .4312-4320.2002$.

55. Delputte PL, Nauwynck HJ. 2004. Porcine arterivirus infection of alveolar macrophages is mediated by sialic acid on the virus. Journal of Virology. 78:8094-8101. doi: 10.1128/JVI.78.15.8094-8101.2004.

56. de Vries AA, Chirnside ED, Horzinek MC, Rottier PJ. 1992. Structural proteins of equine arteritis virus. Journal of Virology. 66:6294-6303.

57. de Vries AA, Post SM, Raamsman MJ, Horzinek MC, Rottier PJ. 1995. The two major envelope proteins of equine arteritis virus associate into disulfide-linked heterodimers. Journal of Virology. 69:4668-4674.

58. Dobbe JC, van der Meer Y, Spaan WJ, Snijder EJ. 2001. Construction of chimeric arteriviruses reveals that the ectodomain of the major glycoprotein is not the main determinant of equine arteritis virus tropism in cell culture. Virology. 288:283-294. doi: 10.1006/viro.2001.1074.

59. Doll ER, Bryans JT, Wilson JC. 1968. Immunization against equine viral arteritis using modified live virus propagated in cell cultures of rabbit kidney. Cornell Veterinary. 48(4):497-524.

60. Du C, Fang M, Li Y, Li L, Wang X. 2000. Smac, a mitochondrial protein that promotes cytochrome c-dependent caspase activation by eliminating IAP inhibition. Cell. 102:33-42.

61. Dubin M, Stoppani AOM. 2000. Muerte celular programada y apoptosis. Medicina. 60:375386. 
62. Dunowska M, Biggs PJ, Zheng T, Perrott MR. 2012.Identification of a novel nidovirus associated with a neurological disease of the Australian brushtail possum (Trichosurus vulpecula). Veterinary Microbiology. 156(3-4):418-424. doi: 10.1016/j.vetmic.2011.11.013.

63. Echeverría MG, Pecoraro MR, Galosi CM, Etcheverrigaray ME, Nosetto EO. 2003. The first isolation of equine arteritis virus in Argentina. Scientific and Technical Review of the Office International des Epizooties. 22:1029-1033.

64. Echeverría MG, Díaz S, Metz GE, Serena MS, Panei CJ, Nosetto E. 2007. Genetic typing of equine arteritis virus isolates from Argentina. Virus Genes. 35(2):313-20. doi: 10.1007/s11262-007-0081-4.

65. Eick D, Hermeking H. 1996. Viruses as pacemakers in the evolution of defence mechanisms against cancer. Trends in Genetics. 12(1):4-6. doi: 10.1016/0168-9525(96)81374-6.

66. Enari M, Sakahira H, Yokoyama H, Okawa K, Iwamatsu A, Nagata S. 1998. A caspaseactivated DNase that degrades DNA during apoptosis, and its inhibitor ICAD. Nature. 391:43-50. doi: 10.1038/34112.

67. Estes PC, Cheville NF. 1970. The ultrastructure of vascular lesions in equine viral arteritis. American Journal of Pathology. 58:235-253.

68. Esposti MD. 2002. The roles of Bid. Apoptosis. 7:433-440. doi: 10.1023/A:1020035124855.

69. Fábián Z, Csatary CM, Szeberényi J, Csatary LK. 2007. p53-independent endoplasmic reticulum stress-mediated cytotoxicity of a Newcastle disease virus strain in tumor cell lines. Journal of Virology. 81(6):2817-2830. doi: 10.1128/JVI.02490-06.

70. Fadok VA, de Cathelineau A, Daleke DL, Henson PM, Bratton DL. 2001. Loss of phospholipid asymmetry and surface exposure of phosphatidylserine is required for phagocytosis of apoptotic cells by macrophages and fibroblasts. Journal of Biological Chemistry. 276:1071-1077. doi: 10.1074/jbc.M003649200.

71. Fernández A, Suárez P, Castro JM, Tabarés E, Díaz-Guerra M. 2002. Characterization of regions in the GP5 protein of porcine reproductive and respiratory syndrome virus required to induce apoptotic cell death. Virus Research. 83: 103-118. doi: 10.1016/S01681702(01)00426-9.

72. Firth AE, Zevenhoven-Dobbe JC, Wills NM, Go YY, Balasuriya UB, Atkins JF, Snijder EJ, Posthuma CC. 2011. Discovery of a small arterivirus gene that overlaps the GP5 coding sequence and is important for virus production. Journal of General Virology. 92:10971106. doi: 10.1099/vir.0.029264-0. 
73. Formigli L, Papucci L, Tani A, Schiavone N, Tempestini A, Orlandini GE, Capaccioli S, Orlandini SZ. 2000. Aponecrosis: morphological and biochemical exploration of a syncretic process of cell death sharing apoptosis and necrosis. Journal of Cellular Physiology. 182:41-49. doi: 10.1002/(SICI)1097-4652(200001)182:1<41::AID-JCP5>3.0.CO;2-7.

74. Fukunaga Y, Imagawa H, Tabuchi E, Akiyama Y. 1981. Clinical and virological findings on experimental equine viral arteritis in horses. Bulletin of the Equine Research Institute. 18:110-118.

75. Fukunaga Y, Matsumura T, Sugiura T, Wada R, Imagawa H, Kanemaru T, Kamada M. 1994. Use of the serum neutralization test for equine viral arteritis with different virus strains. The Veterinary Record. 134:574-576.

76. Gadaleta P, Perfetti X, Mersich S, Coulombié F. 2005. Early activation of the mitochondrial apoptotic pathway in vesicular stomatitis virus-infected cells. Virus Research. 109(1):6569. doi: 10.1016/j.virusres.2004.10.007.

77. Gaddy DF, Lyles DS. 2005. Vesicular stomatitis viruses expressing wild-type or mutant M proteins activate apoptosis through distinct pathways. Journal of Virology. 79(7):41704179. doi: 10.1128/JVI.79.7.4170-4179.2005.

78. Gagnon CA, Lachapelle G, Langelier Y, Massie B, Dea S. 2003. Adenoviral-expressed gP5 of porcine respiratory and reproductive syndrome virus differs in its cellular maturation from the authentic viral protein but maintains known biological functions. Archives of Virology. 148(5):951-972. doi: 10.1007/s00705-002-0943-y.

79. Galindo I, Hernáez B, Muñoz-Moreno R, Cuesta-Geijo MA, Dalmau-Mena I, Alonso C. 2012. The ATF6 branch of unfolded protein response and apoptosis are activated to promote African swine fever virus infection. Cell Death and Disease. 3:e341. doi: 10.1038/cddis.2012.81.

80. Gao J, Ji P, Zhang M, Wang X, Li N, Wang C, Xiao S, Mu Y, Zhao Q, Du T, Sun Y, Hiscox JA, Zhang G, Zhou EM. 2014. gP5 expression in Marc-145 cells inhibits porcine reproductive and respiratory syndrome virus infection by inducing beta interferon activity. Veterinary Microbiology. 174(3-4):409-418. doi: 10.1016/j.vetmic.2014.09.030.

81. Garrido C, Galluzzi L, Brunet M, Puig PE, Didelot C, Kroemer G. 2006. Mechanisms of cytochrome c release from mitochondria. Cell Death and Differentiation. 13:1423-1433. doi: $10.1038 /$ sj.cdd. 4401950 . 
82. Ge M, Zhang Y, Liu Y, Liu T, Zeng F. 2016. Propagation of field highly pathogenic porcine reproductive and respiratory syndrome virus in MARC-145 cells is promoted by cell apoptosis. Virus Research. 213:322-331. doi: 10.1016/j.virusres.2015.12.023.

83. Gerada C, Steain M, McSharry BP, Slobedman B, Abendroth A. 2018. Varicella-Zoster virus ORF63 protects human neuronal and keratinocyte cell lines from apoptosis and changes its localization upon apoptosis induction. Journal of Virology. 92(12). pii: e00338-18. doi: 10.1128/JVI.00338-18.

84. Ghrici M, El Zowalaty M, Omar A, Ideris A. 2013. Induction of apoptosis in MCF-7 cells by the hemagglutinin-neuraminidase glycoprotein of Newcastle disease virus Malaysian strain AF2240. Oncology Reports. 3: 1035-1044. doi: 10.3892/or.2013.2573

85. Glaser AL, de Vries AA, Dubovi EJ. 1995. Comparison of equine arteritis virus isolates using neutralizing monoclonal antibodies and identification of sequence changes in $\mathrm{GL}$ associated with neutralization resistance. Journal of General Virology. 76:2223-2233. doi: 10.1099/0022-1317-76-9-2223.

86. Godeny EK, de Vries AA, Wang XC, Smith SL, de Groot RJ. 1998. Identification of the leader-body junctions for the viral sub-genomic mRNAs and organization of the simian hemorrhagic fever virus genome: evidence for gene duplication during arterivirus evolution. Journal of Virology. 72:862-867.

87. Golnik W, Michalska Z, Michalak T. 1981. Natural equine viral arteritis in foals. Schweiz Arch Tierheilkd. 123:523-533.

88. Gómez-Laguna J, Salguero FJ, Fernández de Marco M, Barranco I, Rodríguez-Gómez IM, Quezada M, Carrasco L. 2013. Type 2 Porcine Reproductive and Respiratory Syndrome virus infection mediated apoptosis in B- and T-cell areas in lymphoid organs of experimentally infected pigs. Transbound and Emerging Diseases. 60(3):273-278. doi: 10.1111/j.1865-1682.2012.01338.x.

89. Gonzalez LJ, De la sota M, Barrandeguy M, Trono K, Ayerbe M, Tarantelli M. 2003. Relevamiento serológico de arteritis viral equina en padrillos registrados en Argentina. In Proceedings of the VIII Congress of the World Equine Veterinary Association. 194-195.

90. Granzow H, Weiland F, Fichtner D, Schütze H, Karger A, Mundt E, Dresenkamp B, Martin P, Mettenleiter TC. 2001. Identification and ultrastructural characterization of a novel virus from fish. Journal of General Virology. 82:2849-2859. doi: 10.1099/0022-1317-82-12-2849. 
91. Grein TA, Weidner T, Czermak P. 2016. Concepts for the production of viruses and viral vectors in cell cultures. New Insights into Cell Culture Technology. doi: 10.5772/66903.

92. Grimm S, Stanger BZ, Leder P. 1996. RIP and FADD: two "death domain"-containing proteins can induce apoptosis by convergent, but dissociable, pathways. Proceedings of the National Academy of Sciences USA. 93: 10923-10927.

93. Groenendyk J, Michalak M. 2005. Endoplasmic reticulum quality control and apoptosis. Acta Biochimica Polonica. 52(2):381-395.

94. Guo R, Davis D, Fang Y3. 2018. Intercellular transfer of mitochondria rescues virus-induced cell death but facilitates cell-to-cell spreading of porcine reproductive and respiratory syndrome virus. Virology. 517:122-134. doi: 10.1016/j.virol.2017.12.018.

95. Hacker G. 2000.The morphology of apoptosis. Cell and Tissue Research. 301:5-17. doi: $10.1007 / \mathrm{s} 004410000193$.

96. Han K, Lee J, Park C, Choi K, Jeong J, Park SJ, Kang I, Chae C. 2016. Differential expression of Porcine Reproductive and Respiratory Syndrome virus (PRRSV) open reading frame 5, but not apoptogenic cytokines, contribute to severe respiratory disease in pigs infected with Type 2 PRRSV compared with pigs infected with Type 1 PRRSV. Journal of Comparative Pathology. 154(2-3):243-252. doi: 10.1016/j.jcpa.2015.12.002.

97. Hans A, Gaudaire D, Tapprest J, Guix E, Marcillaud-Pitel C, Legrand L, Pronost S, Fortier C, Laugier S, Zientara G. 2008. French 2007 Equine viral arteritis outbreak: Epidemiological and pathological features. Second international workshop on equine arteritis virus, Lexington, Kentucky. 40.

98. Harrington EA, Fanidi A, Evan GI. 1994. Oncogenes and cell death. Current Opinion in Genetics \& Development. 4(1):120-129. doi: 10.1016/0959-437X(94)90100-7.

99. Hedges JF, Balasuriya UB, Timoney PJ, McCollum WH, MacLachlan NJ. 1999. Genetic divergence with emergence of novel phenotypic variants of Equine Arteritis Virus during persistent infection of stallions. Journal of Virology. 73(5):3672-3681.

100. Henao LF, Yepes JO, Álvarez CM, Balcázar N, Navas MC. 2004. Expression of the green fluorescent protein and the Hepatitis $C$ virus core protein in the human hepatoma cell line HepG2 using Semliki Forest Virus expression system. Actual Biology. 26(80):23-29.

101. Hill MM, Adrain C, Duriez PJ, Creagh EM, Martin SJ. 2004. Analysis of the composition, assembly kinetics and activity of native Apaf-1 apoptosomes. EMBO Journal. 23:2134-2145. doi: 10.1038/sj.emboj.7600210. 
102. Hirsch T, Marchetti P, Susin SA, Dallaporta B, Zamzami N, Marzo I, Geuskens M, Kroemer G. 1997. The apoptosis-necrosis paradox. Apoptogenic proteases activated after mitochondrial permeability transition determine the mode of cell death. Oncogene. 15:1573-1581. doi: 10.1038/sj.onc.1201324.

103. Holyoak G.R., Giles R.C., McCollum W.H., Little T.V. and Timoney P.J. 1993a. Pathological changes associated with equine arteritis virus infection of the reproductive tract in prepubertal and peripubertal colts. Journal of Comparative Pathology. 109:281293. doi: $10.1016 / \mathrm{S} 0021-9975(08) 80253-8$.

104. Holyoak G.R., Little T.V., McCollum W.H. and Timoney P.J. 1993b. Relationship between onset of puberty and establishment of persistent infection with equine arteritis virus in the experimentally infected colt. Journal of Comparative Pathology. 109:29-46. doi: 10.1016/S0021-9975(08)80238-1.

105. Hornyak A, Bakonyi T, Tekes G, Szeredi L, Rusvai M. 2005. A novel subgroup among genotypes of equine arteritis virus: genetic comparison of 40 strains. Journal of Veterinary Medicine, Series B, Infectious Disease Veterinary Public Health. 52:112-118. doi: 10.1111/j.1439-0450.2005.00833.x.

106. Horvitz HR. 1999. Genetic control of programmed cell death in the nematode Caenorhabditis elegans. Cancer Research. 59:1701s-1706s.

107. Horzinek M, Maess J, Laufs R. 1971. Studies on the substructure of togaviruses. Analysis of equine arteritis, rubella, bovine viral diarrhea, and hog cholera viruses. Archiv fur die gesamte Virusforschung. 33:306-318.

108. Hsu H, Xiong J, Goeddel DV. 1995. The TNF receptor 1-associated protein TRADD signals cell death and NF-kappa B activation. Cell. 81:495-504. doi: 10.1016/00928674(95)90070-5.

109. Hu S, Snipas SJ, Vincenz C, Salvesen G, Dixit VM. 1998. Caspase- 14 is a novel developmentally regulated protease. Journal of Biological Chemistry. 273:29648-29653. doi: $10.1074 / j b c .273 .45 .29648$.

110. Hullinger PJ, Wilson WD, Rossitto PV, Patton JF, Thurmond MC, MacLachlan NJ. 1998. Passive transfer, decay and protein specificity of equine arteritis virus antibodies in an endemically infected standardbred herd. Journal of the American Veterinary Medical Association. 213:839-842. 
111. Hyllseth B. 1969. A plaque assay of equine arteritis virus in BHK-21 cells. Arch Gesamte Virusforsch, 28, 26-33.

112. Igney $\mathrm{FH}$, Krammer $\mathrm{PH}$. 2002. Death and anti-death: tumour resistance to apoptosis. Nature Reviews Cancer. 2:277-288. doi: 10.1038/nrc776.

113. Jayakiran M. 2015. Apoptosis-Biochemistry: A Mini Review. Clinical and Experimental Pathology. 5:1. doi: 10.4172/2161-0681.1000205.

114. Johnson B, Baldwin C, Timoney P, Ely R. 1991. Arteritis in equine fetuses aborted due to equine arteritis virus. Veterinary Pathology. 28:248. doi: 10.1177/030098589102800310.

115. Jones TC, Doll ER, Bryans JT. 1957. The lesion of equine viral arteritis. Cornell Veterinary. 47:52-68.

116. Jordan R, Wang L, Graczyk TM, Block TM, Romano PR. 2002. Replication of a cytopathic strain of bovine viral diarrhea virus activates PERK and induces endoplasmic reticulum stress-mediated apoptosis of MDBK cells. Journal of Virology. 76(19):9588-9599. doi: 10.1128/JVI.76.19.9588-9599.2002.

117. Joza N, Susin SA, Daugas E, Stanford WL, Cho SK, Li CY, Sasaki T, Elia AJ, Cheng HY, Ravagnan L, Ferri KF, Zamzami N, Wakeham A, Hakem R, Yoshida H, Kong YY, Mak TW, Zuniga- Pflucker JC, Kroemer G, Penninger JM. 2001. Essential role of the mitochondrial apoptosis-inducing factor in programmed cell death. Nature. 410:549-554. doi: $10.1038 / 35069004$.

118. Kang SJ, Wang S, Kuida K, Yuan J. 2002. Distinct downstream pathways of caspase11 in regulating apoptosis and cytokine maturation during septic shock response. Cell Death and Differentiation. 9:1115-1125. doi: 10.1038/sj.cdd.4401087.

119. Karniychuk U, Saha D, Geldhof M, Vanhee M, Cornillie P, Van den Broeck W, Nauwynck H. 2011. Porcine reproductive and respiratory syndrome virus (PRRSV) causes apoptosis during its replication in fetal implantation sites. Microbial Pathogenesis. 51: 194202. doi: 10.1016/j.micpath.2011.04.001.

120. Kasibhatla S, Amarante-Mendes GP, Finucane D, Brunner T, Bossy-Wetzel E, Green DR. 2006. Acridine orange/ethidium bromide (AO/EB) staining to detect apoptosis. Cold Spring Harbor Protocols. pii: pdb.prot4493. doi: 10.1101/pdb.prot4493.

121. Kataoka T, Schroter M, Hahne M, Schneider P, Irmler M, Thome M, Froelich CJ, Tschopp J. 1998. FLIP prevents apoptosis induced by death receptors but not by 
perforin/granzyme B, chemotherapeutic drugs, and gamma irradiation. Journal of Immunology. 161:3936-3942.

122. Kerr JF, Wyllie AH, Currie AR. 1972. Apoptosis: a basic biological phenomenon with wide-ranging implications in tissue kinetics. British Journal of Cancer. 26:239-257.

123. Kerr JF. 2002. History of the events leading to the formulation of the apoptosis concept. Toxicology. 181-182:471-474. doi: 10.1016/S0300-483X(02)00457-2.

124. Kischkel FC, Hellbardt S, Behrmann I, Germer M, Pawlita M, Krammer PH, Peter ME. 1995. Cytotoxicity-dependent APO-1 (Fas/CD95)- associated proteins form a deathinducing signaling complex (DISC) with the receptor. EMBO Journal. 14:5579-5588.

125. Koenig U, Eckhart L, Tschachler E. 2001. Evidence that caspase-13 is not a human but a bovine gene. Biochemical and Biophysical Research Communications. 285:11501154. doi: 10.1006/bbrc.2001.5315

126. Konishi S, Akashi H, Sentsui H, Ogata M. 1975. Studies on equine viral arteritis. Characterization of the virus and trial survey on antibody with Vero cell cultures. Nippon Juigaku Zasshi. 37:259-267.

127. Kolb JP, Oguin TH, Oberst A, Martinez J. 2017. Programmed Cell Death and Inflammation: Winter Is Coming. Trends in Immunology. Cell Press. 38(10):705-718. doi: 10.1016/j.it.2017.06.009.

128. Kopecky SA, Lyles DS. 2003. The cell-rounding activity of the vesicular stomatitis virus matrix protein is due to the induction of cell death. Journal of Virology. 77(9):55245528. doi: 10.1128/JVI.77.9.5524-5528.2003.

129. Kopecky SA, Lyles DS. 2003. Contrasting effects of matrix protein on apoptosis in HeLa and BHK cells infected with vesicular stomatitis virus are due to inhibition of host gene expression. Journal of Virology. 77(8):4658-4669. doi: 10.1128/JVI.77.8.46584669.2003.

130. Kothakota S, Azuma T, Reinhard C, Klippel A, Tang J, Chu K, McGarry TJ, Kirschner MW, Koths K, Kwiatkowski DJ, Williams LT. 1997. Caspase-3-generated fragment of gelsolin: effector of morphological change in apoptosis. Science. 278:294-298. doi: 10.1126/science.278.5336.294.

131. Koyama AH. 1995. Induction of apoptotic DNA fragmentation by the infection of vesicular stomatitis virus. Virus Research. 37:285-290. doi: 10.1016/0168-1702(95)00026M. 
132. Koyama AH, Fukumori T, Fujita M, Irie H, Adachi A. 2000. Physiological significance of apoptosis in animal virus infection. Microbes and Infection. 2:1111-1117. doi: $10.1016 / \mathrm{S} 1286-4579(00) 01265-X$

133. Kuhn JH, Lauck M, Bailey AL, Shchetinin AM, Vishnevskaya TV, Bào Y, Ng TF, LeBreton M, Schneider BS, Gillis A, Tamoufe U, Diffo Jle D, Takuo JM, Kondov NO, Coffey LL, Wolfe ND, Delwart E, Clawson AN, Postnikova E, Bollinger L, Lackemeyer MG, Radoshitzky SR, Palacios G, Wada J, Shevtsova ZV, Jahrling PB, Lapin BA, Deriabin PG, Dunowska M, Alkhovsky SV, Rogers J, Friedrich TC, O'Connor DH, Goldberg TL. 2016. Reorganization and expansion of the nidoviral family Arteriviridae. Archives of Virology. 161(3):755-68. doi: 10.1007/s00705-015-2672-z.

134. Kurosaka K, Takahashi M, Watanabe N, Kobayashi Y. 2003. Silent cleanup of very early apoptotic cells by macrophages. Journal of Immunology. 171:4672-4679. doi: 10.4049/jimmunol.171.9.4672.

135. Kwaśnik M, Rożek W, Zmudziński JF. 2013. Induction of apoptosis in MDCK, RK13, and NEURO-2A cells infected with equine influenza virus. Bulletin of the Veterinary Institute in Pulawy. 57:3-7.

136. Labarque G, Van Gucht S, Nauwynck H, Van Reeth K, Pensaert M. 2003. Apoptosis in the lungs of pigs infected with porcine reproductive and respiratory syndrome virus and associations with the production of apoptogenic cytokines. Veterinary Research. 34:249260. doi: $10.1051 /$ vetres:2003001.

137. Lai MMC, Holmes KV. 2001. Coronaviruses. In: Fields Virology. Knipe D.M., Howley P.M. Editors. Lippincott, Williams and Wilkins, Philadelphia, Pennsylvania. 1163-1185.

138. Lauber C, Ziebuhr J, Junglen S, Drosten C, Zirkel F, Nga PT, Morita K, Snijder EJ, Gorbalenya AE. 2012. Mesoniviridae: a proposed new family in the order Nidovirales formed by a single species of mosquito-borne viruses. Archives of Virology. 157(8):16231628. doi: 10.1007/s00705-012-1295-x.

139. Lee C, Bachand A, Murtaugh MP, Yoo D. 2004. Differential host cell gene expression regulated by the porcine reproductive and respiratory syndrome virus GP4 and GP5 glycoproteins. Veterinary Immunology and Immunopathology. 102(3):189-198. doi: 10.1016/j.vetimm.2004.09.020. 
140. Lee S, Kleiboeker S. 2007. Porcine reproductive and respiratory syndrome virus induces apoptosis through a mitochondria-mediated pathway. Virology. 365:419-434. doi: 10.1016/j.virol.2007.04.001.

141. Leist M, Single B, Castoldi AF, Kuhnle S, Nicotera P. 1997. Intracellular adenosine triphosphate (ATP) concentration: a switch in the decision between apoptosis and necrosis. Journal of Experimental Medicine. 185:1481-1486. doi: 10.1084/jem.185.8.1481.

142. Li H, Zhu H, Xu CJ, Yuan J. 1998. Cleavage of BID by caspase-8 mediates the mitochondrial damage in the Fas pathway of apoptosis. Cell. 94:491-501. doi: 10.1016/S0092-8674(00)81590-1.

143. Li LY, Luo X, Wang X. 2001. Endonuclease G is an apoptotic DNase when released from mitochondria. Nature. 412:95-99. doi: 10.1038/35083620.

144. Li S, Zhou A, Wang J, Zhang S. 2016. Interplay of autophagy and apoptosis during PRRSV infection of Marc145 cell. Infection, Genetics and Evolution. 39:51-54. doi: 10.1016/j.meegid.2016.01.011.

145. Li S, Wang J, Zhou A, Khan FA, Hu L, Zhang S. 2016. Porcine reproductive and respiratory syndrome virus triggers mitochondrial fission and mitophagy to attenuate apoptosis. Oncotarget. 7(35):56002-56012. doi: 10.18632/oncotarget.10817.

146. Li XD, Mäkelä TP, Guo D, Soliymani R, Koistinen V, Vapalahti O, Vaheri A, Lankinen H. 2002. Hantavirus nucleocapsid protein interacts with the Fas-mediated apoptosis enhancer Daxx. Journal of General Virology. 83(Pt 4):759-766. doi: 10.1099/0022-1317-834-759.

147. Li XD, Lankinen H, Putkuri N, Vapalahti O, Vaheri A. 2005. Tula hantavirus triggers pro-apoptotic signals of ER stress in Vero E6 cells. Virology. 333(1):180-189. doi: 10.1016/j.virol.2005.01.002.

148. Lin C, Holland RE, Donofrio JC, McCoy MH, Tudor LR, Chambers TM. 2002. Caspase activation in equine influenza virus induced apoptotic cell death. Veterinary Microbiology. 84: 357-365. doi: 10.1016/S0378-1135(01)00468-0.

149. Little TV, Holyoak GR, McCollum WH, Timoney PJ. 1991. Output of equine arteritis virus from persistently infected stallion is testosterone dependent. In: Proceedings of the International Conference of Equine Infectious Diseases. 6:225-229.

150. Little TV, Deregt D, McCollum WH, Timoney PJ. 1995. Evaluation of an immune cytochemical method for rapid detection and identification of equine arteritis virus in 
natural cases of infection. In: Proceedings of the International Conference of Equine Infectious Diseases. 7:27-31.

151. Locksley RM, Killeen N, Lenardo MJ. 2001. The TNF and TNF receptor superfamilies: integrating mammalian biology. Cell. 104:487-501. doi: 10.1016/S00928674(01)00237-9.

152. Lowe SW, Ruley HE. 1993. Stabilization of the p53 tumor suppressor is induced by adenovirus 5 E1A and accompanies apoptosis. Genes and Development. 7(4):535-545. doi: 10.1101/gad.7.4.535.

153. Ma Z, Wang Y, Zhao H, Xu AT, Wang Y, Tang J, Feng WH. 2013. Porcine reproductive and respiratory syndrome virus nonstructural protein 4 induces apoptosis dependent on its 3C-like serine protease activity. PLoS One. 8(7):e69387. doi: 10.1371/journal.pone.0069387.

154. MacLachlan NJ, Balasuriya UB, Rossitto PV, Hullinger PA, Patton JF, Wilson WD. 1996. Fatal experimental equine arteritis virus infection of a pregnant mare: immunohistochemical staining of viral antigens. Journal of Veterinary Diagnostic Investigation. 8:367-374. doi: 10.1177/104063879600800316.

155. MacLachlan NJ, Balasuriya UB, Hedges JF, Schweidler TM, McCollum WH, Timoney PJ, Hullinger PJ, Patton JF. 1998. Serologic response of horses to the structural proteins of equine arteritis virus. Journal of Veterinary Diagnostic Investigation. 10:229-236. doi: $10.1177 / 104063879801000302$.

156. Maestre AM, Garzon A, Rodriguez D. 2011. Equine Torovirus (BEV) induces caspase-mediated apoptosis in infected cells. Cells PLosONE (6): 22972. doi: 10.1371/journal.pone0020972.

157. Magnusson P, Hyllseth B, Marusyk H. 1970. Morphological studies on equine arteritis virus. Arch Gesamte Virusforsch. 30:105-112.

158. McCollum WH, Doll ER, Wilson JC, Johnson CB. 1961. Propagation of equine arteritis virus in monolayer cultures of equine kidney. American Journal of Veterinary Research. 22:731-735.

159. McCollum WH, Doll ER, Wilson JC, Cheatham J. 1962. Isolation and propagation of equine arteritis virus in monolayer cell cultures of rabbit kidney. Cornell Veterinary. $52: 452-458$. 
160. McCollum WH. 1970. Vaccination for equine viral arteritis. In: Proceedings of the International Conference of Equine Infectious Diseases. 2:143-151.

161. McCollum WH, Prickett ME, Bryans JT. 1971. Temporal distribution of equine arteritis virus in respiratory mucosa, tissues and body fluids of horses infected by inhalation. Research in Veterinary Science. 12:459-464.

162. McCollum WH. 1976. Studies of passive immunity in foals to equine viral arteritis. Veterinary Microbiology. 1:45-54.

163. McCollum WH. 1981. Pathologic features of horses given a virulent equine arteritis virus intramuscularly. American Journal of Veterinary Research. 42:1218-1220.

164. McCollum WH. 1986. Responses of horses vaccinated with a virulent modified-live equine arteritis virus propagated in the Equine Dermis (NBL-6) cell line to nasal inoculation with virulent virus. American Journal of Veterinary Research. 47:1931-1934.

165. McCollum WH, Timoney PJ, Roberts AW. 1988. Response of vaccinated and nonvaccinated mares to artificial insemination with semen from stallions persistently infected with equine arteritis virus. In: Proceedings of the International Conference of Equine Infectious Diseases. 5:13-18.

166. McCollum WH, Timoney PJ, Tengelsen LA. 1995. Clinical, virological and serological responses of donkeys to intranasal inoculation with the KY-84 strain of equine arteritis virus. Journal of Comparative Pathology. 112:207-211. doi: 10.1016/S00219975(05)80062-3.

167. Metz GE, Serena MS, Panei CJ, Nosetto EO, Echeverria MG. 2014. The equine arteritis virus isolate from the 2010 Argentinian outbreak. Revue scientifique et technique. 33(3):937-946.

168. Metz GE, Galindo I, Abeyá MM, Echeverria MG, Alonso C. 2016. Intrinsic, extrinsic and endoplasmic reticulum stress-induced apoptosis in RK13 cells infected with equine arteritis virus. Virus Research. 213:219-223. doi: 10.1016/j.virusres.2015.12.010.

169. Metzstein MM, Stanfield GM, Horvitz HR. 1998. Genetics of programmed cell death in Caenorhaditis elegans: past, present and future. Trends in Genetics. 14:410-416. doi: 10.1016/S0168-9525(98)01573-X.

170. Miller L, Fox J. 2004. Apoptosis and porcine reproductive and respiratory syndrome virus. Veterinary Immunology and Immunopathology. 102:131-42. doi: 10.1016/j.vetimm.2004.09.004. 
171. Molenkamp R, van Tol H, Rozier BC, van der Meer Y, Spaan WJ, Snijder EJ. 2000. The arterivirus replicase is the only viral protein required for genome replication and subgenomic mRNA transcription. Journal of General Virology. 81:2491-2496. doi: 10.1099/0022-1317-81-10-2491.

172. Moore BD, Balasuriya UB, Hedges JF, MacLachlan NJ. 2002. Growth characteristics of a highly virulent, a moderately virulent, and an avirulent strain of equine arteritis virus in primary equine endothelial cells are predictive of their virulence to horses. Virology. 298:39-44. Doi 10.1006/viro.2002.1466.

173. Moore BD, Balasuriya UB, Watson JL, Bosio CM, MacKay RJ, MacLachlan NJ. 2003a. Virulent and avirulent strains of equine arteritis virus induce different quantities of TNFalpha and other proinflammatory cytokines in alveolar and blood-derived equine macrophages. Virology. 314:662-670. doi: 10.1016/S0042-6822(03)00506-3.

174. Moore BD, Balasuriya UB, Nurton JP, McCollum WH, Timoney PJ, Guthrie AJ, MacLachlan NJ. 2003b. Differentiation of strains of equine arteritis virus of differing virulence to horses by growth in equine endothelial cells. American Journal of Veterinary Research. 64:779-784. doi: 10.2460/ajvr.2003.64.779.

175. Morishima N, Nakanishi K, Takenouchi H, Shibata T, Yasuhiko Y. 2002. An endoplasmic reticulum stress-specific caspase cascade in apoptosis. Journal of Biological Chemistry. 277:34287-34294. doi:10.1074/jbc.M204973200.

176. Murphy TW, McCollum WH, Timoney PJ, Klingeborn BW, Hyllseth B, Golnik W, Erasmus B. 1992. Genomic variability among globally distributed isolates of equine arteritis virus. Veterinary Microbiology. 32:101-115. doi: 10.1016/0378-1135(92)90099-F.

177. Nagata S. 2018. Apoptosis and Clearance of Apoptotic Cells. Annual Review of Immunology. 36:489-517. doi: 10.1146/annurev-immunol-042617-053010.

178. Nakagawa T, Zhu H, Morishima N, Li E, Xu J, Yankner BA, Yuan J. 2000. Caspase-12 mediates endoplasmic-reticulum-specific apoptosis and cytotoxicity by amyloid-beta. Nature. 403:98-103. doi: 10.1038/47513.

179. Nauwynck HJ, Duan X, Favoreel H, Van Oostveldt P, Pensaert MB. 1999. Entry of porcine reproductive and respiratory syndrome virus into porcine alveolar macrophages via receptor-mediated endocytosis. Journal of General Virology. 80:297-305. doi: 10.1099/0022-1317-80-2-297. 
180. Neu SM, Timoney PJ, McCollum WH. 1987. Persistent infection of the reproductive tract in stallions experimentally infected with equine arteritis virus. In: Proceedings of the International Conference of Equine Infectious Diseases, 14.

181. Neu S.M., Timoney P.J. and Lowry S.R. 1992. Changes in semen quality following experimental equine arteritis virus infection in the stallion. Theriogenology, 37:407-431. doi: 10.1016/0093-691X(92)90199-2.

182. Nomura-Takigawa Y1, Nagano-Fujii M, Deng L, Kitazawa S, Ishido S, Sada K, Hotta H. 2006. Non-structural protein 4A of Hepatitis C virus accumulates on mitochondria and renders the cells prone to undergoing mitochondria-mediated apoptosis. Journal of General Virology. 87(Pt 7):1935-45. doi: 10.1099/vir.0.81701-0.

183. Norbury CJ, Hickson ID. 2001. Cellular responses to DNA damage. Annual Review of Pharmacology and Toxicology. 41:367-401. doi: 10.1146/annurev.pharmtox.41.1.367.

184. Norwitz ER, Robinson JN, Challis JR. 1999. The control of labor. New England Journal of Medicine. 341(9):660-666. doi: 10.1056/NEJM199908263410906.

185. Nosetto EO, Etcheverrigaray ME, Oliva GA, Gonzalez ET, Samus SA. 1984. Arteritis viral equina: deteccion de anticuerpos en equinos de la República Argentina. Zentralblatt für Veterinärmedizin B. 31: 526-529.

186. Novakovic P, Harding JC, Al-Dissi AN, Detmer SE. 2017. Type 2 porcine reproductive and respiratory syndrome virus infection increases apoptosis at the maternal-fetal interface in late gestation pregnant gilts. PLoS One. 12(3):e0173360. doi: 10.1371/journal.pone.0173360.

187. OIE (World Organisation for Animal Health). Chapter 2.5.10. Equine viral arteritis infection with equine arteritis virus. Disponible en: http://www.oie.int/fileadmin/Home/fr/Health_standards/tahm/2.05.10_EVA.pdf [Consultado: 09/02/2018].

188. Oldstone MB. 1989. Viral persistence. Cell. 56:517-520. doi: 10.1016/00928674(89)90573-4.

189. Oldstone MB. 1991. Molecular anatomy of viral persistence. Journal of Virology. 65:6381-6386.

190. Oldstone MB. 1997. Viruses and autoimmune diseases. Scandinavian Journal of Immunology. 46(4):320-325. doi: 10.1046/j.1365-3083.1997.d01-145.x. 
191. Olson MO, Dundr M, Szebeni A. 2000. The nucleolus: an old factory with unexpected capabilities. Trends Cell Biology. 10:189-196. doi: 10.1016/S09628924(00)01738-4.

192. Paweletz N. 2001. Walther Flemming: pioneer of mitosis research. Nature Reviews Molecular Cell Biology. 2:72-75. doi: 10.1038/35048077.

193. Paweska JT, Aitchison H, Chirnside ED, Barnard BJ. 1996. Transmission of the South African asinine strain of equine arteritis virus (EAV) among horses and between donkeys and horses. Journal of Veterinary Research. 63:189-196.

194. Paweska JT, Binns MM, Woods PSA, Chirnside ED. 1997. A survey for antibodies to equine arteritis virus in donkeys, mules and zebra using virus neutralisation (VN) and enzyme linked immunosorbent assay (ELISA). Equine Veterinary Journal. 29:40-43. doi: 10.1111/j.2042-3306.1997.tb01634.x.

195. Pedersen KW, van der Meer Y, Roos N, Snijder EJ. 1999. Open reading frame 1aencoded subunits of the arterivirus replicase induce endoplasmic reticulum-derived double-membrane vesicles which carry the viral replication complex. Journal of Virology. 73:2016-2026.

196. Perlman S, Poon L, Rottier PJ, Talbot PJ, Woo PC, Ziebuhr J. 2012. Family Coronaviridae. In: Virus Taxonomy, Classification and Nomenclature of Viruses. Ninth Report of the International Committee on Taxonomy of Viruses. King AMQ, Adams MJ, Carstens EB, Lefkowitz EJ editors. Elsevier Academic Press, Amsterdam. 806-828.

197. Peter ME, Krammer PH. 1998. Mechanisms of CD95 (APO-1/Fas)-mediated apoptosis. Current Opinion in Immunology. 10:545-551. doi: 10.1016/S09527915(98)80222-7.

198. Pol JM, Wagenaar F, Reus JE. 1997. Comparative morphogenesis of three PRRS virus strains. Veterinary Microbiology. 55:203-208. doi: 10.1016/S0378-1135(96)01329-6.

199. Posthuma C, Nedialkova D, Zevenhoven-Dobbe J, Blokhuis J, Gorbalenya A, Snijder E. 2006. Site-directed mutagenesis of the nidovirus replicative endoribonuclease NendoU exerts pleiotropic effects on the arterivirus life cycle. Journal of Virology. 80:1653-1661. doi: 10.1128/JVI.80.4.1653-1661.2006.

200. Pottie A. 1888. The propagation of influenza from stallions to mares. Journal of Comparative Pathology. 1:37-38. 
201. Préhaud C, Lay S, Dietzschold B, Lafon M. 2003. Glycoprotein of nonpathogenic rabies viruses is a key determinant of human cell apoptosis. Journal of Virology. 77: 1053710547. doi: 10.1128/JVI.77.19.10537-10547.2003.

202. Prickett ME, McCollum WH, Bryans JT. 1972. The gross and microscopic pathology observed in horses experimentally infected with the equine arteritis virus. In: Proceedings of the International Conference of Equine Infectious Diseases. 3:265-272.

203. Prikhod'ko EA, Prikhod'ko GG, Siegel RM, Thompson P, Major ME, Cohen JI. 2004. The NS3 protein of hepatitis C virus induces caspase-8-mediated apoptosis independent of its protease or helicase activities. Virology. 329(1):53-67. doi: 10.1016/j.virol.2004.08.012.

204. Pujhari S, Baig TT, Zakhartchouk AN. 2014. Potential role of porcine reproductive and respiratory syndrome virus structural protein gP2 in apoptosis inhibition. BioMed Research International. Article ID 160505. doi:10.1155/2014/160505.

205. Pujhari S, Zakhartchouk AN. 2016. Porcine reproductive and respiratory syndrome virus envelope $(E)$ protein interacts with mitochondrial proteins and induces apoptosis. Archives of Virology. 161(7):1821-1830. doi: 10.1007/s00705-016-2845-4.

206. Pujhari S, Rasgon JL, Zakhartchouk AN. 2016. Anti-apoptosis in porcine respiratory and reproductive syndrome virus. Virulence. 7(5):610-611. doi: 10.1080/21505594.2016.1162371.

207. Rai NK, Tripathi K, Sharma D, Shukla VK. 2005. Apoptosis: a basic physiologic process in wound healing. International Journal of Lower Extremity Wounds. 4:138-144. doi: $10.1177 / 1534734605280018$.

208. Ramanathan MP, Chambers JA, Pankhong P, Chattergoon M, Attatippaholkun W, Dang K, Shah N, Weiner DB. 2006. Host cell killing by the West Nile Virus NS2B-NS3 proteolytic complex: NS3 alone is sufficient to recruit caspase-8-based apoptotic pathway. Virology. 345(1):56-72. doi: 10.1016/j.virol.2005.08.043.

209. Rao RV, Castro-Obregon S, Frankowski H, Schuler M, Stoka V, del Rio G, Bredesen DE, Ellerby HM. 2002. Coupling endoplasmic reticulum stress to the cell death program. An Apaf-1-independent intrinsic pathway. Journal of Biological Chemistry. 277:21836-21842. doi: $10.1074 / j b c . M 202726200$.

210. Ravindra P, Tiwari A, Sharma B, Rajawat Y, Ratta B, Palia S, Sundaresan N, Chaturvedi U, Kumar G, Chindera K, Saxena M, Subudhi P, Rai A, Chauhan R. 2008. HN 
protein of Newcastle disease virus causes apoptosis in chicken embryo fibroblast cells. Archives of Virology. 153:749-754. doi: 10.1007/s00705-008-0057-2.

211. Rivas J, Neira V, Mena J, Brito B, Garcia A, Gutierrez C, Sandoval D, Ortega R. 2017. Identification of a divergent genotype of equine arteritis virus from South American donkeys. Transboundary and Emerging Disease. 64(6):1655-1660. doi: 10.1111/tbed.12703.

212. Roberson EC1, Tully JE, Guala AS, Reiss JN, Godburn KE, Pociask DA, Alcorn JF, Riches DW, Dienz O, Janssen-Heininger YM, Anathy V. 2012. Influenza induces endoplasmic reticulum stress, caspase-12-dependent apoptosis, and c-Jun $\mathrm{N}$-terminal kinase-mediated transforming growth factor- $\beta$ release in lung epithelial cells. American Journal of Respiratory Cell and Molecular Biology. 46(5):573-81. doi: 10.1165/rcmb.201004600C.

213. Rowland RR, Kervin R, Kuckleburg C, Sperlich A, Benfield DA. 1999. The localization of porcine reproductive and respiratory syndrome virus nucleocapsid protein to the nucleolus of infected cells and identification of a potential nucleolar localization signal sequence. Virus Research. 64:1-12. doi: 10.1016/S0168-1702(99)00048-9.

214. Rubio-Moscardo F, Blesa D, Mestre C, Siebert R, Balasas T, Benito A, Rosenwald A, Climent J, Martinez JI, Schilhabel M, Karran EL, Gesk S, Esteller M, deLeeuw R, Staudt LM, Fernandez-Luna JL, Pinkel D, Dyer MJ, Martinez-Climent JA. 2005. Characterization of 8p21.3 chromosomal deletions in B-cell lymphoma: TRAIL-R1 and TRAIL-R2 as candidate dosage-dependent tumor suppressor genes. Blood. 106:3214-3222. doi: 10.1182/blood2005-05-2013.

215. Rutkowski DT. Kaufman RJ. 2004. A trip to the ER: coping with stress. Trends in Cell Biology. 14:20-28. doi: 10.1016/j.tcb.2003.11.001.

216. Saelens X, Festjens N, Vande Walle L, van Gurp M, van Loo G, Vandenabeele P. 2004. Toxic proteins released from mitochondria in cell death. Oncogene. 23:2861-2874. doi: 10.1038/sj.onc.1207523.

217. Sakahira H, Enari M, Nagata S. 1998. Cleavage of CAD inhibitor in CAD activation and DNA degradation during apoptosis. Nature. 391:96-99. doi: 10.1038/34214.

218. Sarkar S, Chelvarajan L, Go YY, Cook F, Artiushin S, Mondal S, Anderson K, Eberth J, Timoney PJ, Kalbfleisch TS, Bailey E, Balasuriya UB. 2016. Equine Arteritis Virus Uses 
Equine CXCL16 as an Entry Receptor. Journal of Virology. 90(7):3366-84. doi: 10.1128/JVI.02455-15.

219. Sato M, Mikami O, Kobayashi M, Nakajima Y. 2000. Apoptosis in the lymphatic organs of piglets inoculated with classical swine fever virus. Veterinary Microbiology. 75:19. doi: 10.1016/S0378-1135(00)00198-X.

220. Savill J, Fadok V. 2000. Corpse clearance defines the meaning of cell death. Nature. 407:784-788. doi: 10.1038/35037722.

221. Scaffidi C, Schmitz I, Krammer PH, Peter ME. 1999. The role of c-FLIP in modulation of CD95-induced apoptosis. Journal of Biological Chemistry. 274:1541-1548. doi: 10.1074/jbc.274.3.1541.

222. Schimmer AD. 2004. Inhibitor of apoptosis proteins: translating basic knowledge into clinical practice. Cancer Research. 64:7183-7190. doi: 10.1158/0008-5472.CAN-041918.

223. Scrochi MR, Zanuzzi CN, Fuentealba N, Nishida F, Bravi ME, Pacheco ME, Sguazza GH, Gimeno EJ, Portiansky EL, Muglia Cl, Galosi CM, Barbeito CG. 2017. Investigation of apoptosis in cultured cells infected with equine herpesvirus 1. Journal of Biotechnic and Histochemistry. 92(8):560-568. doi: 10.1080/10520295.2017.1359749.

224. Siavoshian S1, Abraham JD, Thumann C, Kieny MP, Schuster C. 2005. Hepatitis C virus core, NS3, NS5A, NS5B proteins induce apoptosis in mature dendritic cells. Journal of Medical Virology. 75(3):402-411. doi: 10.1002/jmv.20283

225. Siddell S, Snijder EJ. 2008. An introduction to nidovirus. In: Nidoviruses. Perlman S, Gallagher T, Snijder EJ editors. ASM Press, Washington, District of Columbia. 1-13.

226. Slee EA, Adrain C, Martin SJ. 2001. Executioner caspase-3, -6, and -7 perform distinct, non-redundant roles during the demolition phase of apoptosis. Journal of Biological Chemistry. 276:7320-7326. doi: 10.1074/jbc.M008363200.

227. Snijder EJ, Meulenberg JJ. 1998. The molecular biology of arteriviruses. Journal of General Virology. 79:961-979. doi: 10.1099/0022-1317-79-5-961.

228. Snijder EJ, van Tol H, Pedersen KW, Raamsman MJ, de Vries AA. 1999. Identification of a novel structural protein of arteriviruses. Journal of Virology. 73:63356345. 
229. Snijder EJ, van Tol H, Roos N, Pedersen KW. 2001. Non-structural proteins 2 and 3 interact to modify host cell membranes during the formation of the arterivirus replication complex. Journal of General Virology. 82:985-994. doi: 10.1099/0022-1317-82-5-985.

230. Snijder EJ, Dobbe JC, Spaan WJ. 2003. Heterodimerization of the two major envelope proteins is essential for arterivirus infectivity. Journal of Virology. 77:97-104. doi: 10.1128/JVI.77.1.97-104.2003.

231. Snijder EJ, Kikkert M, Fang Y. 2013. Arterivirus molecular biology and pathogenesis. Journal of General Virology. 94(Pt 10):2141-2163. doi: 10.1099/vir.0.056341-0.

232. Sperandio S, de Belle I, Bredesen DE. 2000. An alternative, non- apoptotic form of programmed cell death. Proceedings of the National Academy of Sciences, USA. 97:1437614381. doi: 10.1073/pnas.97.26.14376.

233. Stadejek T, Bjorklund H, Bascunana CR, Ciabatti IM, Scicluna MT, Amaddeo D, McCollum WH, Autorino GL, Timoney PJ, Paton DJ, Klingeborn B, Belák S. 1999. Genetic diversity of equine arteritis virus. Journal of General Virology. 80:691-699. doi: 10.1099/0022-1317-80-3-691.

234. Stadejek T., Mittelholzer C., Oleksiewicz M.B., Paweska J. and Belak S. 2006. Highly diverse type of equine arteritis virus (EAV) from the semen of a South African donkey: short communication. Acta Veterinaria Hungarica. 54:263-270. doi: 10.1556/AVet.54.2006.2.12.

235. St-Louis MC, Massie B, Archambault D. 2005. The bovine viral diarrhea virus (BVDV) NS3 protein, when expressed alone in mammalian cells, induces apoptosis which correlates with caspase-8 and caspase-9 activation. Veterinary Research. 36:213-227. doi: 10.1051/vetres:2004059.

236. St-Louis MC, Archambault D. 2007. The equine arteritis virus induces apoptosis via caspase-8 and mitochondria-dependent caspase-9 activation. Virology. 367:147-155. doi: 10.1016/j.virol.2007.05.023.

237. Suárez P, Díaz-Guerra M, Prieto C, Esteban M, Castro JM, Nieto A, Ortín J. 1996. Open reading frame 5 of porcine reproductive and respiratory syndrome virus as a cause of virus-induced apoptosis. Journal of Virology. 70:2876-2882.

238. Suárez P. 2000. Ultrastructural pathogenesis of the PRRS virus. Veterinary Research. 31(1):47-5. doi: 10.1051/vetres:2000107. 
239. Suliman A, Lam A, Datta R, Srivastava RK. 2001. Intracellular mechanisms of TRAIL: apoptosis through mitochondrial -dependent and -independent pathways. Oncogene. 20:2122-2133. doi: 10.1038/sj.onc.1204282.

240. Sur JH, Doster, AR, Osorio, FA. 1998. Apoptosis induced in vivo during acute infection by porcine reproductive and respiratory syndrome virus. Veterinary Pathology. 35:506-514. doi: 10.1177/030098589803500605.

241. Susin SA, Daugas E, Ravagnan L, Samejima K, Zamzami N, Loeffler M, Costantini P, Ferri KF, Irinopoulou T, Prevost MC, Brothers G, Mak TW, Penninger J, Earnshaw WC, Kroemer G. 2000. Two distinct pathways leading to nuclear apoptosis. Journal of Experimental Medicine. 192:571-580. doi: 10.1084/jem.192.4.571.

242. Symonds H, Krall L, Remington L, Saenz-Robles M, Lowe S, Jacks T, Van Dyke T. 1994. p53-dependent apoptosis suppresses tumor growth and progression in vivo. Cell. 78(4):703-711. doi: 10.1016/0092-8674(94)90534-7.

243. Tardif KD, Mori K, Kaufman RJ, Siddiqui A. 2004. Hepatitis C virus suppresses the IRE1-XBP1 pathway of the unfolded protein response. Journal of Biological Chemistry. 279(17):17158-64. doi: 10.1074/jbc.M312144200.

244. Timoney PJ, McCollum WH, Roberts AW, Murphy TW. 1986. Demonstration of the carrier state in naturally acquired equine arteritis virus infection in the stallion. Research in Veterinary Science. 41:279-280.

245. Timoney PJ, McCollum WH. 1987. Equine viral arteritis. Canadian Veterinary Journal. 28:693-695.

246. Timoney PJ, McCollum WH, Murphy TW, Roberts AW, Willard JG, Carswell GD. 1987. The carrier state in equine arteritis virus infection in the stallion with specific emphasis on the venereal mode of virus transmission. Journal of reproduction and fertility. Supplement. 35:95-102.

247. Timoney PJ. 1988. Equine viral arteritis: epidemiology and control. Journal of Equine Veterinary Science, 8:54-59.

248. Timoney PJ, McCollum WH. 1993. Equine viral arteritis. Veterinary Clinics of North America: Equine Practice. 9:295-309. doi: 10.1016/S0749-0739(17)30397-8.

249. Timoney PJ, McCollum WH. 1996. Equine viral arteritis. Equine Veterinary Education. 8:97-100. 
250. Timoney PJ, McCollum WH. 2000. Equine viral arteritis: Further characterization of the carrier state in stallions. Journal of reproduction and fertility. Supplement. 56:3-11.

251. Thomson BJ. 2001. Viruses and apoptosis. International Journal of Experimental Pathology. 82(2):65-76. doi: 10.1111/j.1365-2613.2001.iep0082-0065-x.

252. Umareddy I, Pluquet O, Wang QY, Vasudevan SG, Chevet E, Gu F. 2007. Dengue virus serotype infection specifies the activation of the unfolded protein response. Virology Journal. 4:91. doi: 10.1186/1743-422X-4-91.

253. Vaala WE, Hamir AN, Dubovi EJ, Timoney PJ, Ruiz B. 1992. Fatal, congenitally acquired infection with equine arteritis virus in a neonatal thoroughbred. Equine Veterinary Journal. 24:155-158. doi: 10.1111/j.2042-3306.1992.tb02803.x.

254. van Aken D, Snijder EJ, Gorbalenya AE. 2006. Mutagenesis analysis of the nsp4 main proteinase reveals determinants of arterivirus replicase polyprotein autoprocessing. Journal of Virology. 80:3428-3437. doi: 10.1128/JVI.80.7.3428-3437.2006.

255. van der Meer Y, van Tol H, Locker JK, Snijder EJ. 1998. ORF1a encoded replicase subunits are involved in the membrane association of the arterivirus replication complex. Journal of Virology. 72:6689-6698.

256. van Dinten LC, Rensen S, Gorbalenya AE, Snijder EJ. 1999. Proteolytic processing of the open reading frame $1 \mathrm{~b}$-encoded part of arterivirus replicase is mediated by nsp4 serine protease and is essential for virus replication. Journal of Virology. 73:2027-2037.

257. van Engeland M, Nieland LJ, Ramaekers FC, Schutte B, Reutelingsperger CP. 1998. Annexin V-affinity assay: a review on an apoptosis detection system based on phosphatidylserine exposure. Cytometry. 1:31(1):1-9. doi: 10.1002/(SICI)10970320(19980101)31:13.0.CO;2-R.

258. van Loo G, van Gurp M, Depuydt B, Srinivasula SM, Rodriguez I, Alnemri ES, Gevaert K, Vandekerckhove J, Declercq W, Vandenabeele P. 2002a. The serine protease Omi/HtrA2 is released from mitochondria during apoptosis. Omi interacts with caspaseinhibitor XIAP and induces enhanced caspase activity. Cell Death and Differentiation. 9:2026. doi: $10.1038 /$ sj.cdd. 4400970 .

259. van Loo G, Saelens X, van Gurp M, MacFarlane M, Martin SJ, Vandenabeele P. 2002b. The role of mitochondrial factors in apoptosis: a Russian roulette with more than one bullet. Cell Death and Differentiation. 9:1031-1042. doi: 10.1038/sj.cdd.4401088. 
260. Verheije MH, Welting TJ, Jansen HT, Rottier PJ, Meulenberg JJ. 2002. Chimeric arteriviruses generated by swapping of the $\mathrm{M}$ protein ectodomain rule out a role of this domain in viral targeting. Virology. 303:364-373. doi: 10.1006/viro.2002.1711.

261. Wada R, Fukunaga Y, Kanemaru T, Kondo T. 1996. Histopathological and immunofluorescent studies on transplacental infection in experimentally induced abortion by equine arteritis virus. Zentralblatt fur Veterinarmedizin. Reihe B. 43:65-74.

262. Wajant H. 2002. The Fas signaling pathway: more than a paradigm. Science. 296:1635-1666. doi: 10.1126/science.1071553.

263. Walker PJ, Bonami JR, Boonsaeng V, Chang PS, Cowley JA, Enjuanes L, Flegel TW, Lightner DV, Loh PC, Snijder EJ, Tang K. 2005. Family Roniviridae. In: Virus Taxonomy. Eighth Report of the International Committee on Taxonomy of Viruses. Fauquet CM, Mayo MA, Maniloff J, Desselberger U, Ball LA Editors. Elsevier, Academic Press, Amsterdam. 975979.

264. Wang G, He Y, Tu Y, Liu Y, Zhou EM, Han Z, Jiang C, Wang S, Shi W, Cai X. 2014. Comparative analysis of apoptotic changes in peripheral immune organs and lungs following experimental infection of piglets with highly pathogenic and classical porcine reproductive and respiratory syndrome virus. Virology Journal. 11:2. doi: 10.1186/1743$422 X-11-2$.

265. Wang L, Zhou L, Zhang H, Li Y, Ge X, Guo X, Yu K, Yang H. 2014. Interactome profile of the host cellular proteins and the nonstructural protein 2 of porcine reproductive and respiratory syndrome virus. PLoS One. 9(6):e99176. doi: 10.1371/journal.pone.0099176.

266. Wang L, Zhang K, Lin H, Li W, Wen J, Zhang J, Zhang Y1, Li X, Zhong F. 2014. Preparation of North American type II PRRSV infectious clone expressing green fluorescent protein. BioMed Research International. 2014:368581. doi: 10.1155/2014/368581.

267. Wang P, Arjona A, Zhang Y, Sultana H, Dai J, Yang L, LeBlanc PM, Doiron K, Saleh M, Fikrig E. 2010. Caspase-12 controls West Nile virus infection via the viral RNA receptor RIGI. Nature Immunology. 11(10):912-9. doi: 10.1038/ni.1933.

268. Wang T, Wang X, Li XA, Nie L, Zhang M, Liu S, Zhao X, Shang Y, Zhou EM, Hiscox JA, Xiao Y. 2015. Intranasal inoculation of sows with highly pathogenic porcine reproductive and respiratory syndrome virus at mid-gestation causes transplacental infection of fetuses. Veterinary Research. 46:142. doi: 10.1186/s13567-015-0283-z. 
269. Wang X, Shao C, Wang L, Li Q, Song H, Fang W. 2016. The viral non-structural protein 1 alpha (Nsp1 $\alpha$ ) inhibits p53 apoptosis activity by increasing murine double minute $2(\mathrm{mdm} 2)$ expression in porcine reproductive and respiratory syndrome virus (PRRSV) early-infected cells. Veterinary Microbiology. 184:73-79. doi: 10.1016/j.vetmic.2016.01.009.

270. Weber H, Beckmann K, Haas L. 2006. Case report: equine arteritis virus (EAV) as the cause of abortion in alpacas?. Deutsche tierarztliche Wochenschrift. 113:162-163.

271. Wyers F, Richard-Molard C, Blondel D, Dezelee S. 1980. Vesicular stomatitis virus growth in Drosophila melanogaster cells: G protein deficiency. Journal of Virology. 33(1): 411-422

272. White K, Grether ME, Abrams JM, Young L, Farrell K, Steller H. 1994. Genetic control of programmed cell death in Drosophila. Science. 264(5159):677-683. doi: 10.1126/science.8171319.

273. Wieringa R, de Vries AA, Raamsman MJ, Rottier PJ. 2002. Characterization of two new structural glycoproteins, $\mathrm{gP}(3)$ and $\mathrm{gP}(4)$, of equine arteritis virus. Journal of Virology. 76:10829-10840. doi: 10.1128/JVI.76.21.10829-10840.2002.

274. Wieringa R, de Vries AA, Rottier PJ. 2003a. Formation of disulfide-linked complexes between the three minor envelope glycoproteins ( $\mathrm{gP} 2 \mathrm{~b}, \mathrm{gP} 3$, and $\mathrm{gP} 4$ ) of equine arteritis virus. Journal of Virology. 77:6216-6226. doi: 10.1128\%2FJVI.77.11.6216-6226.2003.

275. Wieringa R, De Vries AA, Post SM, Rottier PJ. 2003b. Intra- and intermolecular disulfide bonds of the gP2b glycoprotein of equine arteritis virus: relevance for virus assembly and infectivity. Journal of Virology. 77:12996-13004. doi: 10.1128/JVI.77.24.12996-13004.2003.

276. Wieringa R, de Vries AA, van der Meulen J, Godeke GJ, Onderwater JJ, van Tol H, Koerten HK, Mommaas AM, Snijder EJ, Rottier PJ. 2004. Structural protein requirements in equine arteritis virus assembly. Journal of Virology. 78:13019-13027. doi: 10.1128/JVI.78.23.13019-13027.2004.

277. Wilkins PA, Del Piero F, Lopez J, Cline M. 1995. Recognition of bronchopulmonary dysplasia in a newborn foal. Equine Veterinary Journal. 27:398. doi: 10.1111/j.20423306.1995.tb04077.x. 
278. Wilson JC, Doll ER, Mc CW, Cheatham J. 1962. Propagation of equine arteritis virus previously adapted to cell cultures of equine kidney in monolayer cultures of hamster kidney. Cornell Veterinarian. 52:200-205.

279. Wurm T, Chen H, Hodgson T, Britton P, Brooks G, Hiscox JA. 2001. Localization to the nucleolus is a common feature of coronavirus nucleoproteins, and the protein may disrupt host cell division. Journal of Virology. 75:9345-9356.

280. Yang TC, Shiu SL, Chuang PH, Lin YJ, Wan L, Lan YC, Lin CW. 2009.Japanese encephalitis virus ns2B-ns3 protease induces caspase 3 activation and mitochondriamediated apoptosis in human medulloblastoma cells. Virus Research. 143(1):77-85. doi: 10.1016/j.virusres.2009.03.007.

281. Yang C, Diiorio P, Jurczyk A, O'Sullivan-Murphy B, Urano F, Bortell R. 2013. Pathological endoplasmic reticulum stress mediated by the IRE1 pathway contributes to pre-insulitic beta cell apoptosis in a virus-induced rat model of type 1 diabetes. Diabetologia. 56(12):2638-2646. doi: 10.1007/s00125-013-3044-4.

282. Yasmin F, Yaqub T, Idrees M, Shahzad W, Hashmi AS, Aqil K, Mukhtar N, Zahoor MY, Akhtar N, Umar S. 2018. Cloning and expression of ns3 gene of Pakistani isolate Type 2 Dengue Virus. Journal of Veterinary Research. 62(1):17-26. doi: 10.2478/jvetres-20180003.

283. Yu CY, Hsu YW, Liao CL, Lin YL. 2006. Flavivirus infection activates the XBP1 pathway of the unfolded protein response to cope with endoplasmic reticulum stress. Journal of Virology. 80(23):11868-11880. doi: 10.1128/JVI.00879-06.

284. Yuan S, Zhang N, Xu L, Zhou L, Ge X, Guo X, Yang H. 2016. Induction of apoptosis by the nonstructural protein 4 and 10 of porcine reproductive and respiratory syndrome virus. PLoS One. 11(6):e0156518. doi: 10.1371/journal.pone.0156518.

285. Zeiss CJ. 2003. The apoptosis-necrosis continuum: insights from genetically altered mice. Veterinary Pathology. 40:481-495. doi: 10.1354/vp.40-5-481.

286. Zhang HM, Ye X, Su Y, Yuan J, Liu Z, Stein DA, Yang D. 2010. Coxsackievirus B3 infection activates the unfolded protein response and induces apoptosis through downregulation of p58IPK and activation of CHOP and SREBP1. Journal of Virology. 84(17):8446-8459. doi: 10.1128/JVI.01416-09.

287. Zhang J, Timoney PJ, Shuck KM, Seoul G, Go YY, Lu Z, Powell DG, Meade BJ, Balasuriya UB. 2010. Molecular epidemiology and genetic characterization of equine 
arteritis virus isolates associated with the 2006-2007 multi-state disease occurrence in the USA. Journal of General Virology. 91:2286-2301. doi: 10.1099/vir.0.019737-0.

288. Zhou A, Li S, Khan FA, Zhang S. 2016. Autophagy postpones apoptotic cell death in PRRSV infection through Bad-Beclin1 interaction. Virulence. 7(2):98-109. doi: 10.1080/21505594.2015.1131381.

289. Ziebuhr J, Snijder EJ, Gorbalenya AE. 2000. Virus-encoded proteinases and proteolytic processing in the Nidovirales. Journal of General Virology. 81-853-879. doi: 10.1099/0022-1317-81-4-853. 